\title{
The Emancipatory JUStice Claim
}

\author{
Richard Lehun \\ Faculty of Law McGill University \\ April 2014
}

A thesis submitted to McGill University in partial fulfillment of the requirements of the degree of Doctor of Civil Law

(C) Richard Lehun, 2014 


\section{Table of Contents}

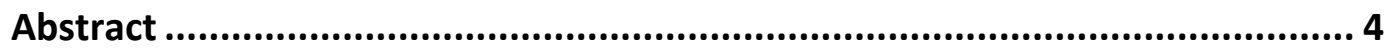

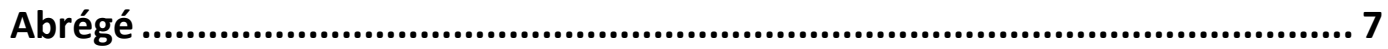

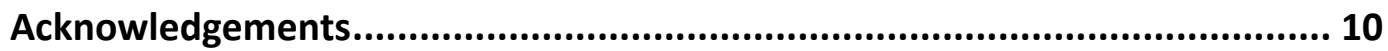

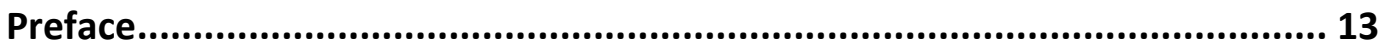

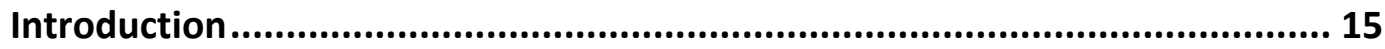

Chapter 1: Conceptual Architecture............................................................... 31

The Justice Matrix and the Emancipatory Claim ............................................... 31

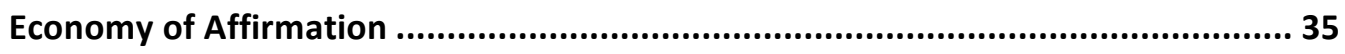

Justice Resources and Antinomical Burdens ...................................................... 40

Antinomical Overburdening and Legacy Subjectivity .......................................... 47

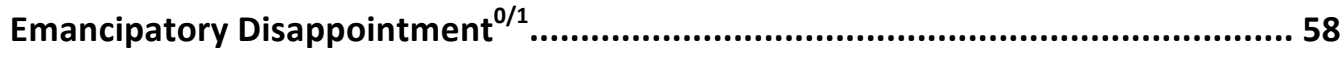

Conclusion: The Legal Subject Flees the Burden of Emancipation ..........................64 64

Chapter 2: Sources of the Legal ....................................................................67 67

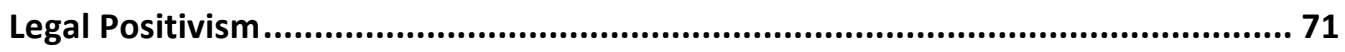

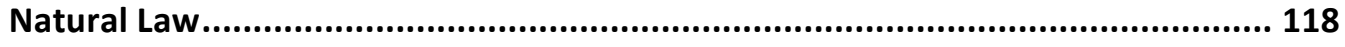

Beyond Legal Positivism and Natural Law: Duncan Kennedy and Legal Work....... 144

But Does the Law Begin and End with the Legal? ........................................ 151

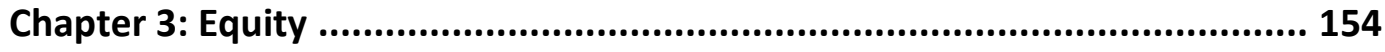

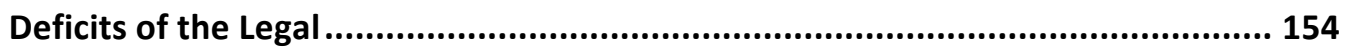

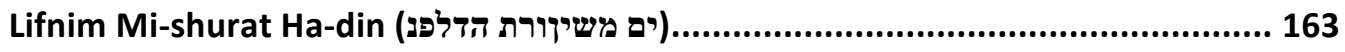

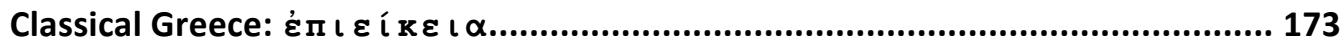




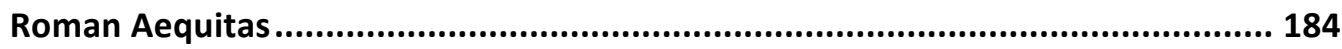

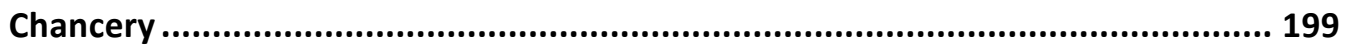

Chapter 4: Fiduciary Relations and Antinomical Burdens ........................... 215

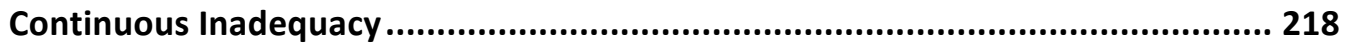

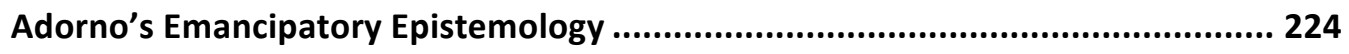

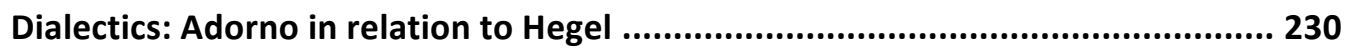

(Negative) Dialectics and the (Non)Identical.................................................... 239

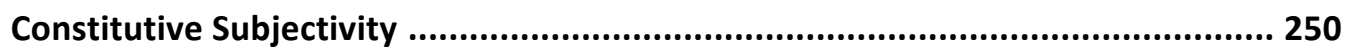

The Economy of Affirmation and Adorno ....................................................... 256

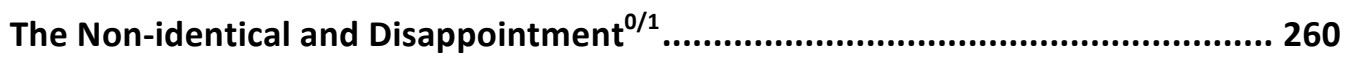

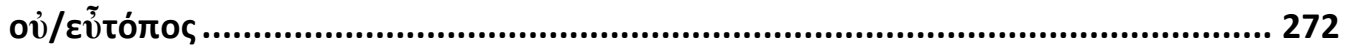

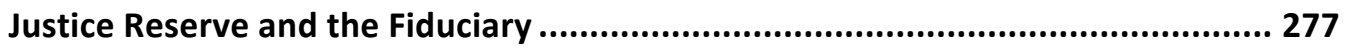

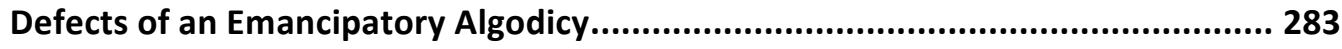

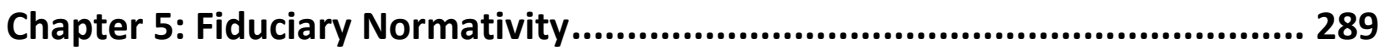

The Reception of the Fiduciary Relationship by Equity...................................... 290

Macro vs. Micro-normative Fiduciary Adjudication .......................................... 302

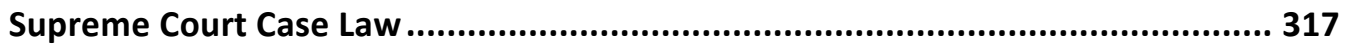

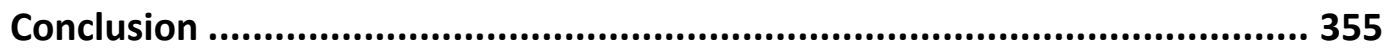

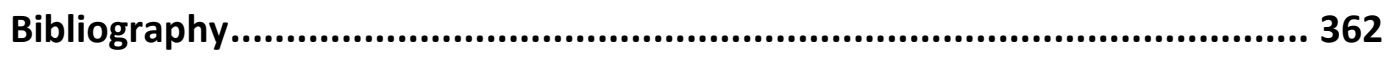




\section{Abstract}

Laws supply us with guidelines and solutions. But what if our survival were to depend on normative transformations that the law is structurally disabled from recognizing? How do we deal with a contradiction between the persistence of law, and the need to enable outcomes that negate the law, as it currently exists? If one asks this question, one begins to make a counter-factual justice claim, an emancipatory claim. This thesis argues that the evolution of collective otherregarding norms cannot be visualized using the existing frame of reference of legal legitimacy.

The first chapter introduces key concepts relating to the emancipatory justice claim. They include: (i) a justice matrix: the differentiation and contextualization of often structurally contradictory justice claims; (ii) an economy of affirmation: epistemological constraints that limit justice expectations; (iii) justice resources: the allocations made towards justice outcomes; (iv) antinomical burdening: the challenge posed by parallel and mutually exclusive justice outcomes to which an economy of affirmation responds; (v) legacy subjectivity: an existing horizon of individual expectations for justice; and (vi) emancipatory 
disappointment: the characteristic of emancipatory moments that makes them inadequate to render the justice claims they assert.

The second chapter analyzes contemporary understandings of the legal, as manifested in legal positivist and natural law theories. The goal is to show how both assert emancipatory justice claims and close them off, thus creating a threshold of inadequacy within the law.

In the third chapter, I examine the shifting emancipatory potential of equity through its Jewish, Classical Greek, Roman, and English iterations. Law has throughout history struggled with its own emancipatory inadequacy by acknowledging an otherness within it.

The fourth chapter offers a theory of how to confront the law's continuous inadequacy in light of such emancipatory claims. Here I contextualize Adorno's critique of epistemology and trace the interdependence of critical epistemology and critique of justice.

The fifth and last chapter looks at the expansion of other-regarding fiduciary duties and their potential relevance to macro-normative challenges. I close with a critique of two supreme Court of Canada cases in order to illustrate the shortcomings of existing 
fiduciary theories and jurisprudence in light of the theory elaborated here. 


\section{Abrégé}

Les catégories juridiques nous fournissent des directives et des solutions. Mais que faisons-nous si notre survie dépend maintenant d'une transformation normative que la loi est structurellement incapable de permettre? Comment pouvons-nous faire face à la contradiction entre la persistance du juridique, et le besoin de permettre des résultats qui déconstruisent la nature du juridique actuel? Si l'on pose cette question, on commence à faire une revendication de justice émancipatrice. Cette thèse énonce que l'évolution vers une constellation de normes collectives orientées vers l'autrui - les normes fiduciaires - ne peut pas être visualisées en utilisant le cadre existant pour déterminer la légitimité juridique. La thèse examine comment la transformation sociale peut être envisagée à travers une nouvelle compréhension de la durabilité normative.

Le premier chapitre introduit les concepts clés pour la contextualisation d'une revendication de justice émancipatrice. Elles sont: (i) une matrice de justice : la différenciation et la contextualisation des revendications de la justice souvent contradictoires; (ii) une économie de l'affirmation : les con- 
traintes épistémologiques qui limitent ce qui est attendu de la justice; (iii) les ressources de la justice : ce qui est alloué pour rendre justice; (iv) les surcharges antinomiques : le défi lancé par des résultats de la justice parallèles et mutuellement exclusives auxquels une économie de l'affirmation répond; (v) le patrimoine de la subjectivité : l'horizon actuel des attentes individuelles en matière de justice; et (vi) la déception de l'émancipation : la caractéristique des moments de l'émancipation qui les laisse inadéquats pour rendre la justice qu'ils affirment.

Le deuxième chapitre analyse les interprétations du juridique offertes par les écoles de positivisme et jus naturalisme. L'objectif est de montrer comment les deux écoles affirment les revendications de justice émancipatrice tout en les restreindre à outrance, créant ainsi un seuil d'insuffisance dans le concept de droit.

Dans le troisième chapitre, nous examinons l'évolution du potentiel émancipateur de l'«équité» à travers ses itérations dans la tradition Talmudique, grecque antique, romaine, et anglaise. Tout au long de l'histoire, le juridique a lutté avec sa propre insuf- 
fisance émancipatrice en reconnaissant une altérité intérieure au droit.

Le quatrième chapitre théorise comment le droit pourrait acquérir une capacité de confronter sa propre insuffisance perpétuelle. Je contextualise la critique d'Adornienne de l'épistémologie et trace l'interdépendance entre l'épistémologie critique et la justice.

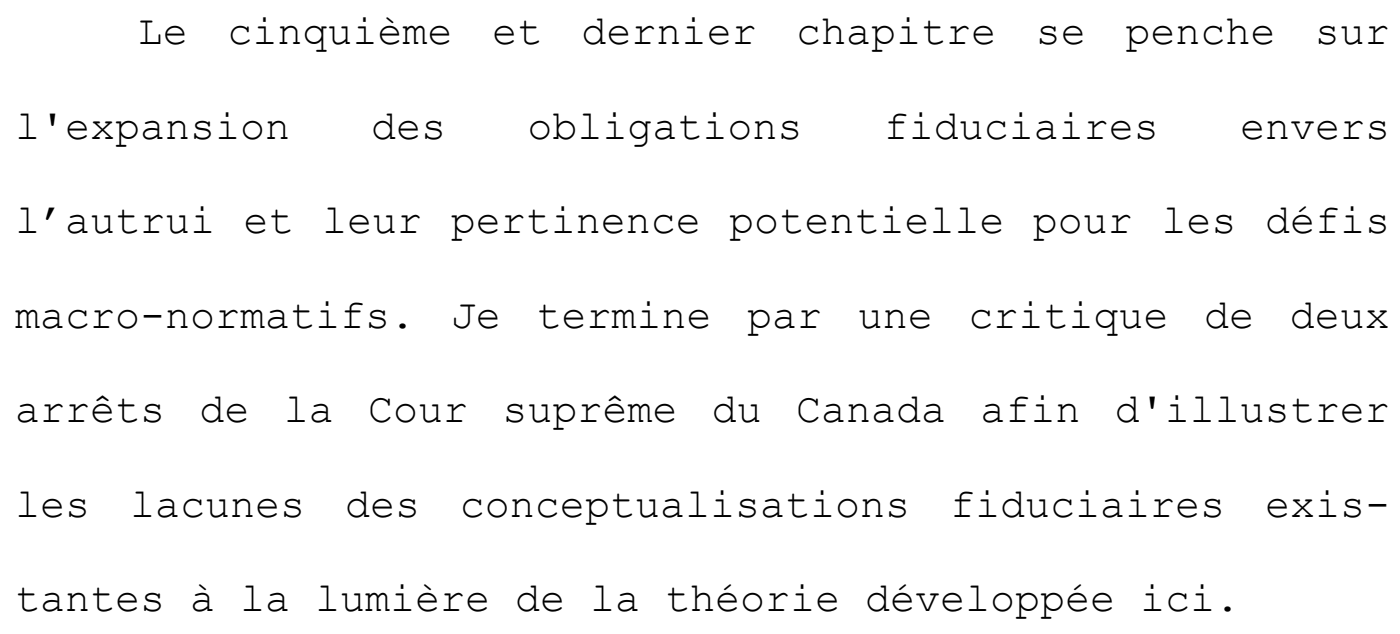
macro-normatifs. Je termine par une critique de deux arrêts de la Cour suprême du Canada afin d'illustrer les lacunes des conceptualisations fiduciaires existantes à la lumière de la théorie développée ici. 


\section{Acknowledgements}

I would like to thank many people who have helped me through the completion of this dissertation. The first is my advisor, Richard Janda, without whose untiring idealism, support, and vision this thesis would never have been possible. This thesis is as much mine as it is a tribute to his steadfast desire to see legal research embrace issues that will give us the needed agency to embrace our real challenges. I was blessed at McGill's Faculty of Law with an unparalleled scholarly environment, a sine qua non for the thesis' intellectual project. Particular thanks are due to Rod Macdonald whose candour, rigor, and pedagogical insights have shifted my perception of academic accountability evermore. I would like to thank Peter G. Brown at the Department of Geography for his support and the opportunity of testing the value of the thesis within the context of his lifetime of service to the preservation of our environment. I am deeply indebted to Pierre Noreau at the Centre de recherche en droit public de l'Université de Montréal for his longstanding support and his insights into the unique demands of a Québecois emancipatory vision. I would like to thank the Social Sciences and Humanities 
Research Council of Canada, which has graciously provided the funding for this dissertation.

At the Freie Universtität in Berlin, I had the honour of developing my ideas under the guidance of Hubert Rottleuthner, whose understanding and encouragement of the breadth of the project made an unforgettable impact. Matthias Mahlmann's indefatigable inter-disciplinary critique sharpened this project from at early stage and greatly facilitated the bridge between classical and modern jurisprudential thought. I would like to extend my personal gratitude to Andreas Fijal, whose generosity and intellectual sincerity lastingly marked my experience at the Freie Universität.

The last two years of the thesis were spent at Harvard Law School, where I enjoyed incomparable encouragement. In particular, Robert Sittkoff's unfaltering preparedness to examine the legal implications of the thesis was critical in contextualizing it within established debates. I am very grateful to Tamar Frankel at Boston University School of Law for the hours we spent exploring the richness of her expertise on the concept of the fiduciary. 
I would like finally to extend my profound gratitude and debt to those who have gone beyond any reasonable measure to permit me to complete this project. Without you, even Richard Janda's extraordinary and poignant efforts could not have flourished. Against all odds, you are a testament to the willingness to sacrifice that anyone would be truly privileged to experience. 


\section{Preface}

T. W. Adorno's untimely death left two parts of an intended trilogy unfinished. The Negative Dialectics ${ }^{1}$ was published under his own hand in 1966. His Aesthetic Theory ${ }^{2}$ was completed from fragments, but his moral theory was never formally started. ${ }^{3}$ Adorno's reception in the English-speaking world has been one of puzzled marginalization. ${ }^{4}$

This thesis establishes and elaborates threshold claims related to emancipatory justice located in epistemological/normative critique. Its intended contribution is to show the significance of Adorno's thought to the further evolution of the conception of justice. The methodological innovation proposed here is to frame divergent discourses within a metatheoret-

\footnotetext{
1 Theodor W Adorno, Negative Dialectics, translated by EB Ashton

2 Theodor W Adorno, Gretel Adorno \& Rolf Tiedemann, Aesthetic Theory, translated by Robert Hullot-Kentor (Minneapolis: University of Minnesota Press, 1997).

3 Rolf Wiggerhaus, The Frankfurt School: Its History, Theories, and Political Significance, translated by Michael Robertson (Cambridge, MA: MIT Press, 1995) at 600.

4 Joshua Rayman explores this theme: "My concern here is not to [...] examine Adorno's American reception in order to understand why his work was marginalized for so many years and to argue that it should not have been marginalized because its message was directly relevant to an America in which it was still possible to constitute resistance or even to envision alternatives to the totalizing, scientific-cultural complex known as the culture industry." Joshua Rayman, "Adorno's American Reception" (2009) 2009:149 Telos 6 .
} 
ical ${ }^{5}$ framework that allows their relationship to emancipatory justice claims to become visible.

5 Theory generally involves some form of ordering contemplation, seeing, or speculation. The Greek root contains both $\theta \varepsilon \omega \rho \varepsilon \omega$

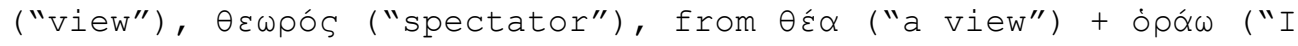
see, look"). Anyone involved in theory can potentially produce a valuable perspective and ordering that shifts or adds to our understanding. A distinction between theorists and theorizing may be valuable to distinguish the breadth or depth of a particular methodology, but the distinction will tend to be formalistic absent explicit extrinsic criteria. The emphasis on metatheory in this thesis is inseparable from the consideration of justice thresholds. The concurrent analysis of the interdependence of normative and epistemic considerations contextualized with the critique of theory has its goal of overcoming the battle of methodologies. 


\title{
Introduction
}

\author{
Whereas the twentieth century was marked by dysto- \\ pian ideological conflicts, we presently face issues \\ stemming from natural limits. ${ }^{6}$ The scope of our respon- \\ sibility has exceeded that of any previous historical \\ period. ${ }^{7}$ For example, the vast scale, unsustainability, \\ and sheer irrationality of environmental destruction ${ }^{8}$ \\ are themselves in direct correlation to the deficits
}

\footnotetext{
6 Our survival is a relevant benchmark for the analysis of law's failure. Laws are made, and as such always have a teleological dimension. I do not hold out that we have an ultimate responsibility to survive. An emancipatory justice claim based on that premise would to be easily reduced to it, and thus compromised by it. Nor can natural limits (planetary boundaries) simply be posited as axiomatic. According to an emancipatory justice analysis, nothing is pre-determined. By contrast, a legal paradigm that is unable to prevent avoidable self-destruction cannot satisfy a teleological analysis. The juxtaposition of law's teleological failure and natural limits is not meant to be axiomatic either. Just because alternatives to existing laws could respond to natural limits more effectively does not in itself mandate their adoption. At the same time, the legitimacy of laws cannot be performatively expressed without a teleological component. That is to say that the moment something is understood as law, it must also always have a relationship to a purpose. In contrast to the legal positivists who are discussed in this thesis, I am not arguing that this fact is enough to distinguish what law is. However, any law would necessarily have to be open to analysis of this kind, even if the analysis uncovered that the purposive dimension could not be specified easily. In this thesis natural limits deliver one specific frame of reference for macro-normative failure. They do not define what the law should do.

7 See generally Andrew Goudie, The Human Impact on the Natural Environment: Past, Present, and Future, 6th ed (Hoboken, NJ: Wiley-Blackwell, 2005). Anthony D Barnosky et al, "Approaching a State Shift in Earth's Biosphere" (2012) 486:7401 Nature 52.

8 For a review of the failure of the sustainability project see, Ingolfur Bluhdorn \& Ian Welsh, eds, The Politics of Unsustainability: Eco-Politics in the Post-Ecologist Era (London: Routledge, 2008).
} 
of the contemporary legal paradigm. ${ }^{9}$

\author{
Remarkably, any possible response to the acuteness \\ of the threat is not situated in the hands of those \\ who are powerful enough to exercise judgment. ${ }^{10}$ In- \\ stead, a significant barrier to our potential survival \\ may be found in our reliance on patterns of rationali- \\ ty underpinning legal legitimacy. ${ }^{11}$ Legal categories
}

\footnotetext{
9 By contemporary legal paradigm, I mean the way in which positive law, natural law and equity -- the main organizing categories of law discussed in this thesis in chapters two and three -- interact in the discourses and practices of modernity. I use the term "paradigm" in the singular because although, quite evidently, there is a wide variety to those discourses and practices, this thesis seeks to explore, through its metatheoretical analysis, the limiting thresholds of possible discourse and practice that encircle modern law in capitalism. I acknowledge that there are counter discourses and practices at the margins of capitalism, for example in indigenous law or within certain religious traditions. However, I claim that within the contemporary legal constellation, no counter discourse or practice has remained untouched by the threshold moments identified in this thesis. This does not assert that this paradigm is substantively uniform or self-understood, but rather that the paradigm is reproduced using widely accepted methodologies dependent on forms of affirmative rationality. An analysis of the limitations of this rationality is explored throughout this thesis. Natural law and positive law theories are paradigmatic legal narratives not only because of their longstanding contribution to what we understand the law to be, but also because of the widespread acceptance of the framing they both prioritize. As explored in this thesis, each framing itself creates a threshold behind which it is impossible to slip, without engendering a crisis of legitimacy. In this sense, natural law and positive law understandings, are have become as necessary to our understanding of the legal as any practice related to it.

10 See generally, Matthew J Hoffmann, Climate Governance at the Crossroads: Experimenting with a Global Response after Kyoto (Oxford: Oxford University Press, 2011).

11 Legitimacy is understood throughout this text as containing both the sense of being "recognized", generally accepted as valid, as well as of being held to a standard beyond existing expectations. In this sense, legal legitimacy is both an affirmative and a critical concept. The ability to sustain this tension is at its core. For this reason, both poles of "legitimacy" play a central role in the understanding the emergence of fiduciary relationships as developed here in the final chapter.
} 
supply us with guidelines and solutions. But what do we do if our existence now depends on normative transformations that the law is structurally disabled from recognizing? How do we deal with the contradiction between the persistence of law, and the need to enable outcomes that negate its very nature? If one asks this question, one makes a counter-factual claim justice claim, an emancipatory claim.

Within the framework of the dissertation, emancipatory justice claims are those that seek to overcome the limitations of justice claims that are already recognized by law within what I will call the existing justice matrix. Emancipatory claims are otherregarding in that they pertain to that which is not contained within the confines of a given subjectivity. The alterity of emancipatory claims places them outside of our existing justice horizon. Emancipatory claims are both other-regarding and alteritygenerating

To be enabled to act on a global scale, the needed constellation of collective other-regarding norms fiduciary norms - cannot be visualized using the ex- 
isting frame of reference for legal legitimacy. ${ }^{12}$ The autonomous legal subject, along with the concomitant ideology of subjective choice, itself a justice claim, require fundamental transformation. ${ }^{13}$ That transformation must confront unprecedented problems of social accountability for planetary impacts, what I term macro-normative challenges. ${ }^{14}$

The first chapter of this thesis will briefly introduce a number of key concepts for the contextualization of an emancipatory justice claim. They are: (i) a justice matrix, which differentiates and places in relationship the existing set of often contradicto-

12 This thesis will focus on what has been called "modern" "occidental" or "western" law. It is beyond its scope to explore emancipatory claims in all legal traditions. The interplay between common law and civil law is reflected in the complex relationship of Roman law, Canon law, and English Equity discussed in chapter three.

13 Desmond Manderson pursued this theme in his book, Proximity, Levinas and the Soul of Law (Montreal: McGill-Queen's Press, 2006). Jonathan Crowe accurately summarizes the point this way: "Manderson draws a distinction early on in his book between selfand other-oriented approaches to legal discourse. He observes that the common law as a whole has traditionally been motivated by a focus on the autonomous legal subject, reflected in the key notions of freedom, contract and individual rights." See Jonathan Crowe, "Self and Other in Ethics and Law: A Comment on Manderson" (2008) 33 Austl J Leg Phil 145 at 147. The relationship between the autonomous legal subject and the ideology of subjective choice is elaborated in the section on Bentham at page 95 ff. 14 Macro-normative analysis relates to existing structural inadequacies reproduced by the law and its epistemic presumptions across multiple iterations. Whereas such inadequacies can lead to discrete injustices, this analysis in this thesis focuses on the relationship between justice claims that all may legitimately at least tentatively affirm (i.e. survival of the species) and the structural barriers to satisfying them. The private law dimension of emancipatory justice is explored in part through the discussion of fiduciary relationships. Nevertheless, the focus of the thesis is methodological rather than doctrinal. 
ry justice claims; (ii) an economy of affirmation, which facilitates the analysis of how epistemes relate to the limits on justice expectations; (iii) justice resources, which are the set of investments, tangible and intangible, made in enabling justice outcomes; (iv) antinomical burdening, ${ }^{15}$ which is how the economy of affirmation ${ }^{16}$ responds to and shapes our capacity for justice differentiation; (v) legacy subjectivity, which is reproduced through an existing economy of affirmation; and (vi) emancipatory disappointment, which accompanies the constant inadequacy of rendering justice in the face of antinomical overburdening. The economy of affirmation and legacy subjectivity cast into relief the ambivalence of the existing legal subject. Both concepts contain justice claims that contribute toward their reproduction even in the face of macro-normative failures. The localization and characterization of both concepts are in my analysis linchpins for any possible sustainable social trans-

15 An antinomical burden is defined here as the difficulty or ambivalence created by the fact that more than one normative ordering is being affirmed at the same time. An antinomy is the combination of áví against + vópos law, commonly understood as "a contradiction in a law, or between two equally binding laws", or as a "conflict of authority." The Oxford English Dictionary, 2d ed (New York: Oxford University Press, USA, 1989).

16 An economy of affirmation reproduces the norms and knowledge that can be taken on at any given moment. That which we could know can typically find only fractional and fragmentary expression in what is normatively affirmed. 
formation. The exploration of the paradoxes surrounding structurally immanent emancipatory failures, what I call disappointment $0^{0 / 1}$, illuminates the concepts of antinomical overburdening and justice resourcing.

The entire first chapter will be dedicated to framing the question as to what type of epistemic/normative thresholds would be required to recalibrate our consciousness surrounding macro-normative transformation. This account explicitly responds to the implosion of emancipatory ideologies during the twentieth century

The second chapter will analyse the implications of these concepts for existing conceptualizations of law, as manifested in influential currents of legal positivist and natural law theory. I will be looking at the emancipatory elements in Bentham's, Kelsen's, and Hart's legal positivist positions, and contrast them with the natural law positions of Finnis and Alexy. The goal of the chapter is to show how legal positivism and natural law both assert emancipatory justice claims and close them off, thus reproducing a threshold of inadequacy .

In the analysis of legal positivism, natural law, and equity, I will undertake to bring the analytical 
framework of the first chapter to bear on both their emancipatory and reactionary characteristics. The role of metatheory here is to dispense with the illusion of the incommensurability of these characteristics.

Each refracts a normative/epistemic constellation and embodies justice unavoidabilities, threshold features of law that must survive any transformation at the risk of total illegitimacy. Evolutions in law and thought respond to intrinsic and extrinsic forces. These forces in turn have a direct impact on the resourcing of justice alterity, namely visions of justice outside of the scope of our expectations. I will argue that while equity embraces this open-ended relationship to possible justice, it is the fiduciary relationship that shares the closest proximity with the emancipatory justice claim by virtue of its connection with justice indeterminacy .

In the third chapter, I will juxtapose and analyze the shifting emancipatory potential of concepts of equity through their expression in Jewish, Classical Greek, Roman, and English legal traditions. The goal of the chapter is to illustrate how law has throughout history struggled with its own inadequacy by acknowledging an otherness within it. 
The fourth chapter will elaborate a theory of how the law as modeled in this thesis could be enabled to confront its own macro-normative fiduciary inadequacy. In this section I will use Adorno's critique of epistemology in the Negative Dialectics ${ }^{17}$ to seek threshold concepts of a transformed justice imaginary. ${ }^{18}$ Using Adorno's concepts of the non-identical and of negative dialectics, the other-regarding characteristic of the fiduciary can be modeled in a manner otherwise impossible. Even if Adorno's frame of reference is anchored in the philosophy of mind, the epistemic/normative thresholds remain relevant to law and justice. Negative dialectics is to be understood here less as a philosophical reflection, and more as a prolegomenon for future moral theory.

The fifth and last chapter will look at relevance of the theory of the fiduciary elaborated here for public law and macro-normative challenges. I will

\footnotetext{
17 Adorno, supra note 1 .

18 This I understand to reside in the penumbra between the most highly differentiated aggregate justice outcome commonly imaginable, and the alterity of an emancipatory claim that eludes concrete conceptualization. A justice imaginary inspires an ethos (the character of the collective, its guiding norms), and through it heterogeneous, unrealized claims are visualized that are otherwise inaccessible to a given normative ordering. The current justice imaginary places such unrealized claims at the threshold of incorporation into an ethos - witness, for example, the recent shift in our justice imaginary concerning gay marriage, which not so long ago could barely even be formulated as a justice claim.
} 
briefly review two key supreme court of Canada rulings. Canada is at the forefront of fiduciary developments, partly due to the role the concept has played in the relations to aboriginal peoples. The juxtaposition of two leading cases in fiduciary law serves to illustrate the difficulties that the supreme court encounters when it deploys fiduciary conceptions within the existing normative/epistemic paradigm. I will argue that current definitions of fiduciary obligations suffer from an insufficiently differentiated normative/epistemic frame of reference for their analysis.

This chapter directly addresses examples of macronormative issues that are currently confronted within a fiduciary framework and shows how the ideas represented here could be applied. Performing a similar mapping of metatheory to theory in specialized fields of law would be beyond the scope of this thesis.

Thus the overall goal of the thesis is to explore the relationship between emancipatory claims and fiduciary obligations. In so doing, the intent is to show how fiduciary obligations can be better understood across their divergent scope of application. At the same time, I argue that fiduciary obligations are a locus for expression of emancipatory claims, particu- 
larly in relationship to justice alterity and indeterminacy

The macro-normative critique here can only be effective by being axiomatic (though not apodictic): but for its consideration certain justice outcomes are significantly less likely. ${ }^{19}$ This is particularly the case with regard to emancipatory justice claims.

Whereas many emancipatory projects have posited collective outcomes, the approach taken here does not offer an affirmative position. Instead, the intent is to interrogate the ideology ${ }^{20}$ underlying the epistemology of the legal, in relation to its implicit and explicit emancipatory narratives. ${ }^{21}$ My intent, however, is not to reveal an otherness that would offer redemption, but rather to suggest threshold ${ }^{22}$ concepts needed

19 As Finnis puts it, "[...] there is no escaping the theoretical requirement that a judgment of significance and importance must be made if theory is to be more than a vast rubbish heap of miscellaneous facts described in a multitude of incommensurable terminologies." John Finnis, Natural Law and Natural Rights, 2 d ed (Oxford: Oxford University Press, 2011) at 17 .

20 Understood as a "hegemonic universalization project". Jürgen Habermas, The Theory of Communicative Action, translated by Thomas McCarthy (Boston: Beacon Press, 1984) at 16-19.

$21 \theta \varepsilon \omega ́ p \eta \mu \alpha$, in the Ancient Greek sense of a spectacle that begs affirmation. This metaphor comprises the following elements. Much theory is born of the attempt to provide an explanation of observable phenomenon, hence rooted in spectacle. If we understand the relationship between instrumental rationality and theory, then both the choice of the phenomenon and manner of seeing it are predicated on affirmation. In this sense, theory is a spectral manifestation predicated on affirmation.

22 A threshold concept is a form of justice axiom, or unavoidiblity. As explored later, once articulated all interactions of 
to model macro-normative outcomes.

Theories of justice ${ }^{23}$ generally rely on apodictic reasoning, this thesis is focused on metatheory. ${ }^{24}$ Theory depends on convincing the reader through logically certain judgment, and through the necessary relationship between clear concepts and arguments based on them. It is worth summarizing briefly some of the inadequacies of theory that this thesis is seeking to confront.

Peter V. Zima, in his monograph what is Theory?: Cultural Theory as Discourse and Dialogue summarizes the relationship between instrumental reason and a conventional understanding of theory: "[...] Weber could try to justify his postulate of a value-free (werfrei) science, a science situated well beyond the neverending struggles among value judgements and value systems."25 The fact that this kind of science is governed by "instrumental reason" in the sense of Max Horkheim-

justice that fail to take such an axiom into account will be structurally inadequate.

${ }^{23}$ I will explore the conventional concepts of justice primarily through theories of positive law and natural law.

${ }^{24}$ Cf. Oliver Wendell Holmes, "The Path of Law" in Harold Joseph Laski, ed, Collected Legal Papers (New York: Harcourt, Brace and Howe, 1920) at 198-201 ("We have too little theory in the law rather than too much [...]. Theory is the most important part of the dogma of law, as the architect is the most important man who takes part in the building of a house. It is not to be feared as unpractical, for, to the competent, it simply means going to the bottom of the subject.").

${ }_{25} \mathrm{P}$ V Zima, What is Theory?: Cultural Theory as Discourse and Dialogue (London: New York: Continuum, 2007) at 65. 
er has been emphasized time and again.

For Gernot Böhme, instrumental reason prevails in modern societies: "The idea that science can also be different, is repressed and forgotten, and every single scientific approach is anxious to parade as science (in the sense of modern science) in order to be able to compete - psychoanalysis is a case in point."26

Brian Fay in his article, "Theory And Metatheory in Social Science - or, Why the Philosophy of Social Science Is So Hard", stresses that,

because meta theoretical arguments in the social sciences explicitly invoke the different metaphysical claims they presuppose, it is going to be the case that, even though rational, such arguments will be more tenuous than one might like. A relative inconclusiveness is likely to be the order of the day. Moreover, there is another factor besides their metaphysical character which makes metatheoretical disputes about the social sciences explosive; this is their political dimension.

Thus, there are good reasons why metatheoretical disputes about the social sciences are so explosive and intractable: they involve different answers to the most basic question of the subject, namely, what is the nature of social science; they involve at their center metaphysical principles of a very high order of abstraction; and they raise ideological considerations of very great intensity. Moreover, social science is itself comprised of a variety of different sorts of theory, all of which embody a different meta theory more or less self-consciously; this means that metatheoreticians cannot simply look at what social scientists do in order to defend their analyses, for such a

\footnotetext{
26 Gernot Böhme, Ethics in Context: The Art of Dealing with Serious Questions, translated by Edmund Jephcott, 1st ed (Cambridge, UK: Malden, MA: Polity, 2001) at 67 .
} 
procedure would beg the very question at issue."27

Horkeimer and Adorno emphasize that the relationship

between theory, reason, and inadequacy:

After civil virtue and love of humanity (for which it already had no adequate grounds), philosophy proceeded to proclaim authority and hierarchy as virtues, when the Enlightenment had long posited them as lies. But the Enlightenment possesses no argument against even such a perversion of its proper nature, for the plain truth had no advantage over distortion, and rationalization none over the ratio, if they could prove no practical benefit in themselves. With the formalization of reason, to the extent that its preferred function is that of a symbol for neutral procedures, theory itself becomes an incomprehensible concept, and thought appears meaningful only when meaning has been discarded. Once it is harnessed to the dominant mode of production, the Enlightenment-which strives to undermine any order which has become repressive-abrogates itself. ${ }^{28}$

By contrast, metatheory has the goal of enabling the reader to understand what he or she has been asked to obscure in order for an argument to be rendered coherent, and why this is so. ${ }^{29}$ This is reflected methodologically in the focus on how macro-normative trans-

27 Brian Fay, "Theory and Metatheory in Social Science-or, Why the Philosophy of Social Science Is So Hard" (1985) 16:2-3 Metaphilosophy 150 .

28 Max Horkheimer \& Theodor W Adorno Dialectic of Enlightenment, translated by John Cumming (New York: Continuum, 1999) at 93.

29 Such enabling is inseparable from the forms of justice this thesis is intending to model. Thus this thesis is explicitly designed not to give the reader a closed form of argumentation that can be reproduced by stringing together a series of (pre)defined elements. When successful, this text will use a constellational form to link normatively mutually opposing $\theta \varepsilon \omega ́ p \eta \mu \alpha \tau$ (theoremae) and show their interdependent justice claims. 
formation ${ }^{30}$ goes hand in hand with a changed appreciation of, and identification with, issues of normative sustainability ${ }^{31}$

In summary, this thesis presents an understanding of macro-normative transformation ${ }^{32}$ through critical epistemology ${ }^{33}$ of the legal subject ${ }^{34}$; a shift in the threshold of other-regarding for law's legitimacy; the analysis of antinomical burdens and their mediation; and an epistemic threshold that delegitimizes the reproduction of the legal economy of affirmation ${ }^{35}$, while at the same time accounting for legacy claims. ${ }^{36}$

30 The implosion of emancipatory ideologies in the last century resulted from the error of asserting a de novo normative order that dispensed with the ballast accumulated by its predecessor. The resulting emancipatory implosion produces a chimeric monstrosity. Bolshevism and National Socialism being prime examples of this in the twentieth century. This is not to assert that radical transformation is incapable of changing our relationship to law. I do argue, however, that the constellation of justice claims present before any transformation form a legacy horizon that every transformation must sublate; that is, must carry over without extinguishing.

31 To dispense with the normative anchoring of positive law would create a legitimacy deficit greater than the problem ostensibly solved. Cf Francis Fukuyama, The End of History and the Last Man (New York: Free Press, 2006).

32 A macro-normative emancipatory result can be understood as something on the dimensions of universal suffrage or the abolition of slavery. A macro-normative emancipatory problem would be, for example, what position could the positive law have toward property rights so as to disable unsustainable, ecocidal outcomes by enabling individuals to embrace other relationships to nonrenewables and to other actors.

${ }_{33}$ Here understood as the inquiry into what we know of knowing.

34 Forms of economic and political reproduction that take place within the individual. The concept of (legal) subjectivity is revisited throughout the length of the thesis; and is specifically explored in the section on constitutive subjectivity. 35 An indirect outcome of this thesis is a modeling normative thresholds that would allow radical social transformation without 
The challenge of this thesis is to straddle paradigms, vocabularies, and contradictory values regarding appropriate content. It is an exercise that may prove frustrating for the reader at certain points. The neologisms that I introduce may be subject to skepticism and resistance. The difficulty is that many existing concepts do not consciously reflect (nor are they capable of so doing) the interdependence of epistemology and justice that I am exploring here. The goal of this thesis is to make each section speak both to normative and epistemic thresholds. ${ }^{37}$

The heterogeneity of the source material produces a patchwork of theories, each of which strives to be judged on its own merits. The justice claims, emanci-

tyrannical consequences. A parallel goal is to identify the structurally totalitarian characteristics of conventionally reproduced epistemes. "I would define the episteme retrospectively as the strategic apparatus which permits of separating out from among all the statements which are possible those that will be acceptable within, I won't say a scientific theory, but a field of scientificity, and which it is possible to say are true or false. The episteme is the 'apparatus' which makes possible the separation, not of the true from the false, but of what may from what may not be characterised as scientific." Michel Foucault, Power/Knowledge, translated by Colin Gordon (New York: Pantheon Books, 1980) at 197 .

36 There can be no macro-normative shift without identifying epistemological pre-requisites for the sublation of positive law's justice externalities, the injustice created when rendering justice.

37 Whereas, there is a consciousness of conceptual contingency in the social sciences, this can easily be wrought as relativism and academicism. See Pierre Schlag, "Spam Jurisprudence, Air Law, and the Rank Anxiety of Nothing Happening (a Report on the State of the Art)" (2007) SSRN eLibrary, online:

<http://papers.ssrn.com/sol3/papers.cfm?abstract_id=976078>. 
patory claims, and epistemic horizon implicit in each normative iteration explored here cannot be contextualized without the difficult task of engaging in metatheory

If we are to posit sustainable macro-normative transformation, then the primacy of competing normative paradigms must be surrendered without giving up their core emancipatory justice claims. Metatheory inspires the contextualization of such claims through the model of a justice matrix, explored at the outset and deployed throughout the thesis. 


\title{
Chapter 1: Conceptual Architecture
}

\author{
This chapter sets the emancipatory justice claim \\ into relief as against antinomical burdens, and iden- \\ tifies the horizon of disappointment that reinforces \\ legal subjectivity's resistance to emancipatory \\ claims. ${ }^{38}$ Although this chapter proceeds through a se- \\ quential discussion of key concepts, these are best \\ understood as forming a constellation.
}

\section{The Justice Matrix and the Emancipatory Claim}

The justice matrix maps concurrent justice affirmations. Each pole of the matrix - conventional, metaphysical and subjective - designates a discrete basis of rightfulness. ${ }^{39}$ The justice matrix is the linchpin for understanding the constellational elements of apo-

\footnotetext{
38 While legal norms are reproduced by their capacity to attract or overlap with an economy of affirmation, future legitimacy is contingent on resourcing the continuous inclusion of emancipatory claims. A central contention of the thesis is that that contemporary instrumental rationality relied upon by our legal archetypes is purposely undifferentiated and thus epistemically defective. In Dialectic of Enlightenment, supra note 28, Horkheimer and Adorno describe this inherent defect of legal modernity as follows (at 81): "Reason contributes only the idea of systematic unity, the formal elements of fixed conceptual coherence. Every substantial goal which men might adduce as an alleged rational insight is, in the strict Enlightenment sense, delusion, lies or 'rationalization,' even though individual philosophers try to advance from this conclusion toward the postulate of philanthropic emotion."

39 Rightfulness is to be distinguished from justice, here understood as an aggregate of claims. Rightfulness is the perception and/or conviction that there is something about a given set of facts that is necessarily open to reflection regarding its appropriateness or legitimacy.
} 
retic justice claims. It is intended as a framing device to visualize competing justice claims.

Conventional justice claims embody normative affirmations that are deemed just because of wide adoption and legal institutionalization. Metaphysical claims are rooted in divine or sacred notions of right. Subjective claims evolve through rational, subjectively convincing critique. ${ }^{40}$ An economy of affirmation affirms and reproduces a limited set of justice claims among these possible poles. ${ }^{41}$ Emancipatory claims are those justice expectations that are not being met in the existing economy of affirmation. Below is an illustration of an analysis of justice aggregates using the justice matrix:

40 These might also be called "conceptual" claims insofar as concepts of justice evolve through rational, subjectively convincing critique. The concept of the subjective claim plays on the interdependence between reason and constitutive subjectivity. As explored in the Dialectic of Enlightenment, supra note 28 reason is both instrumentalized with regard to survival, and a sine qua non of certain types of (self) reflection. In this sense, the subjective justice pole reflects both the reflective, self-sublating as well as the instrumentalized, self-reproducing aspects of reason. 41 see supra note 16 . 


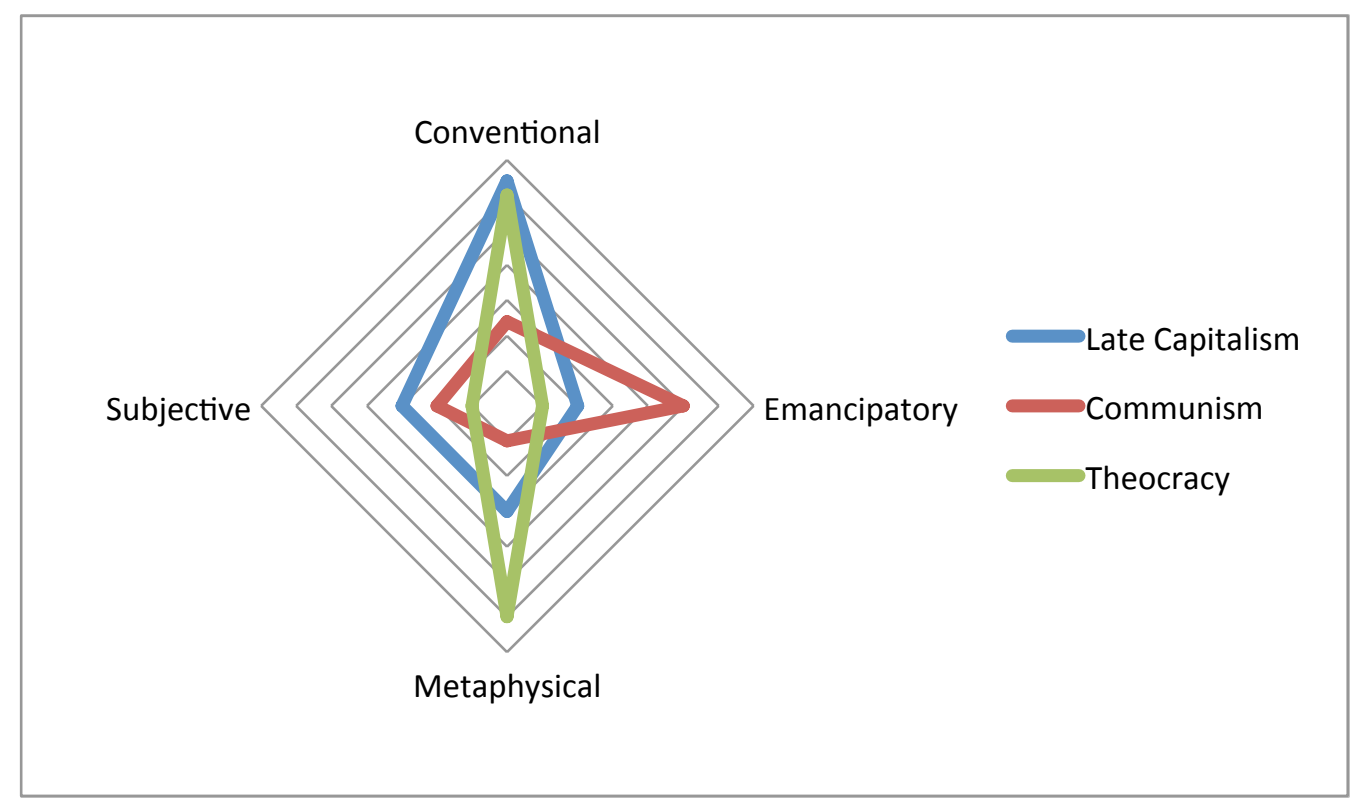

Within the justice matrix, the notion of subjective and emancipatory justice can be understood as counterparts of self-regarding and other-regarding. Self-regarding is in tension with the limitlessness of the emancipatory claim. Whereas the boundaries of possible subjective justice claims are restricted by different resource thresholds, the emancipatory claim reproduces itself on the basis of an otherness that is an inherent part of subjectivity that can never be exhausted. ${ }^{42}$

Conventional and metaphysical justice are radical counterparts of what is fashioned and what is given ${ }^{43}$,

\footnotetext{
42 In this sense it can be compared to Habermas's speech rationality. See generally, Habermas, supra note 20.

43 In "Gifts and Commodities" (1982), Gregory argued that "[c]ommodity exchange is an exchange of alienable objects between people who are in a state of reciprocal independence that estab-
} 
and are thus also poised against each other. The deficit of conventional justice is poised against the limitlessness of metaphysical justice, a justice to come. ${ }^{44}$

Late capitalism ${ }^{45}$ generally configures justice most tightly around the conventional and subjective poles, as is captured in large part by the centrality of individual rights and the rule of law. Communism, in its theory and not its real-existing socialist form, sought to legitimate itself principally around

lishes a quantitative relationship between the objects exchanged. [...] Gift exchange is an exchange of inalienable objects between people who are in a state of reciprocal dependence that establishes a qualitative relationship between the transactors." To posit emancipatory claims as a form of reciprocity is to forgo their alterity. The very essence of emancipatory claims is that they extend beyond existing relationship and horizons of expectation. Emancipatory claims cannot be a basis for exchange because they are not constrained by reciprocity. As such they are in continuous tension with the possibility of relationship. Chris A Gregory, Gifts and Commodities (London: Academic Press, 1982) at $100-101$.

${ }_{44}$ Although once affirmed and identified, metaphysical claims can elide into conventional claims.

${ }^{45}$ Late capitalism, a phrase adopted from the economist Ernest Mandel (Ernest Mandel, Late Capitalism (London: Verso, 1998)) categorized by global corporations, globalized markets, mass consumption, and flows of capital) may be understood here through Frederic Jameson's book Postmodernism, Or The Cultural Logic of Late Capitalism: "postmodernism [is] something like a literal translation' in cultural terms of the economic descriptor 'late capitalist'. To say that my two terms, the cultural and the economic thereby collapse back into one another and say the same thing, in an eclipse of the distinction between base and superstructure that has itself often struck people as significantly characteristic of postmodernism in the first place, is also to suggest that the base, in the third stage of capitalism, generates it superstructures with a new kind of dynamic." Fredric Jameson, Postmodernism, or, The Cultural Logic of Late Capitalism, Reprint ed (Durham: Duke University Press Books, 1990) at xxi. 
the emancipatory pole and diminished the significance of the subjective and conventional, and all but evacuated the metaphysical. Contemporary theocracy, on the other hand, conjoins the metaphysical and the conventional and all but evacuates the subjective and the emancipatory

\section{Economy of Affirmation}

An economy of affirmation is thus a nexus of norms and knowledge that is collectively affirmed at a given moment. A given totality of knowledge can typically find only partial expression in that which is normatively affirmed. There are values and concepts whose evolution and reproduction would either be too complicated to produce, or impose unacceptable burdens.

Let us take the example of property rights to nonrenewable resources. ${ }^{46}$ At the core of a conventional understanding of property is a bundle of rights (usus, fructus and abusus), enforceable against all others ${ }^{47}$. These rights taken together involve mastery over un-

\footnotetext{
46 Non-renewable resource is a good in relation to which greater consumption today entails less consumption of the same tomorrow. Djavad Salehi-Isfahani \& Jacques Crémer, Models of the Oil Market (Chur: Harwood Academic Publishers, 1991).

47 See generally, Gary D Libecap, "Contracting for Property Rights" in Terry Lee Anderson \& Fred S McChesney, eds, Property Rights: Cooperation, Conflict, and Law (Princeton, NJ: Princeton University Press, 2003) 145.
} 
derlying resources up to and including the point of their destruction. The bundle of rights - a kind of fasces symbolizing power and authority - is not in principle itself subject to disability or liability, and certainly does not engage any supervening requirement of stewardship. ${ }^{48}$

The justice deficit that thereby arises concerns whatever is non-renewable in the resources and whatever costs are imposed upon others now and in the future through the use that is made of property. In short, property conventionally understood functions to shield us from an unavoidable collective burden: the determination as to when the use of non-renewable resources is just.

The allocation and consumption of property involves externalities, that is, collateral damage in the name of the constellation of normative values and practical benefits that are socially affirmed. ${ }^{49}$ A col-

\footnotetext{
48 For the relationship among rights, disabilities and liabilities see Wesley Hohfeld, "Fundamental Legal Conceptions as Applied in Judicial Reasoning" (1913) 23 Yale LJ 16 and "Fundamental Legal Conceptions as Applied in Judicial Reasoning" (1917) 27 Yale LJ 710 .

49 Apart from non-renewable natural resources such as oil, Jared Diamond lists examples such as deforestation, habitat destruction, soil problems (erosion, salinization, and soil fertility losses), water management problems, overhunting, overfishing, anthropogenic climate change, build-up of toxins in the environment and energy shortages. See Jared M Diamond, Collapse: How Societies Choose to Fail or Succeed (New York: Viking, 2005).
} 
lective may democratically construe property rights in non-renewable resources as a necessary element of its understanding of justice. ${ }^{50}$ If this is consistent with conventional law, the exhaustion of such a resource is legal. The related externalities are justified in light of a multi-dimensional epistemological and normative value investment, namely an economy of affirmation. Collective normative identification with the necessity of such property rights produces a value in and of itself for that society. ${ }^{51}$

The cost of shifting or transforming the economy of affirmation may be perceived or experienced as prohibitive. Other outcomes are not resourced because they are understood as (i) likely to undermine the existing consensus, causing ambivalence through antinomical burdening, ${ }^{52}$ and (ii) require a transformation of

50 The US Republican and other right leaning parties are paradigmatic examples of this.

51 Finnis characterizes this a part of the ultimate moral goods that positive law is capable of contributing towards: "[t]he service of providing a complete set of uniquely correct answers, is itself in the service of a wider good which like all basic human goods is not reducible to a definite goal but is rather an openended good in which persons and their communities can participate without ever capturing or exhausting it: the good of just harmony. This good is a moral good just insofar as it is itself promoted and respected as one aspect of the ideal of integral human fulfillment. As a moral good its implications are specified by all the moral principles that could bear upon it." See Finnis, supra note 19 at 12 .

52 For a definition, see supra note 15 . There is a fuller discussion of antinomical burdens and overburdening in the next two sections of this chapter. 
the justice imaginary, ${ }^{53}$ leading to greater demands on societal resources, i.e. the re-collectivization of decision-making. It will often be the collective perception that alternative outcomes involve injustice and unacceptable uncertainty. An economy of affirmation can be seen as based on the implicit or explicit exclusion of antinomical burdening and emancipatory claims, while at the same time experienced as an acceptable method of negotiating both.

The significance of the forgoing becomes clear when we turn to the role of law in this analysis. The law is structurally ill suited to calling into question the validity of the economy of affirmation: it is in fact the latter's formal expression. Furthermore, both an economy of affirmation and the law that it produces are inseparable from a justice horizon. There can be no convincing sense of right ${ }^{4}$ without them. Assuming the economy of affirmation produces normative moments independent of any formal legal legitimacy, ${ }^{55}$

\footnotetext{
53 Regarding the concept "justice imaginary," see supra note 18 and accompanying discussion.

54 All conceptions of justice are driven by impulses around a sense of right. The justice matrix maps interdependent claims that are rooted in such impulses. Whereas a diffuse sense of right speaks to the question of justice, justice itself can only properly understood as an aggregate of antinomical claims. See supra note 39.

55 Alexy lists the following legal positivist frames, viz. those arguments raised for the value of law beyond any moral considera-
} 
there is a justice claim surrounding its (irrational)

persistence independent of the irremediable harm caused.

There is a parallel justice claim involved in the law's right to reflect this, for example in evoking "community standards."56 Thus, for example, if the notion of community standards is drawn into the law from the economy of affirmation, this can be done so as to fix in place existing norms, or instead to enable the evolution of those norms. ${ }^{57}$

I argue that the justice externalities thus created will have a direct relationship to the critical epistemic and epistemological resources deployed so as to delimit or expand the justice claims that localize the conventional economy of affirmation.

tions: analytical certainty of expression as language, clarity, effectiveness, legal certainty, reducing relativism, strengthening the distinction between the legislature and the judiciary as democracy, dispensability, and candour. See Robert Alexy, The Argument from Injustice: A Reply to Legal Positivism (Oxford: Clarendon Press, 2002).

56 For an example of how courts evoke community standards, see $R \mathrm{~V}$ Butler, [1992] 1 SCR 452 at 449 (using "community standards" to judge the harm of pornography).

57 Little Sisters Book and Art Emporium V Canada (Minister of Justice), 2000 SCC 69, is arguably an example of the former, since it used community standards to uphold controls against "obscene" gay literature, whereas $R$ V Labaye, 2005 SCC 80, is arguably an example of the latter, since it refused to apply a community standards test to consensual group sex activities in the absence of harm. 


\title{
Justice Resources and Antinomical Burdens
}

\author{
An economy of affirmation instantiates legitimacy \\ because of its capacity to mesh related social struc- \\ tures together. The concept stands in relation to We- \\ ber's concepts of legitimation and rationalization, as \\ I will now seek to explain. By contrast, however, the \\ economy of affirmation concept opens up an analysis of \\ justice resources needed to overcome existing patterns \\ of legitimation and antinomical burdens generated by \\ them. Insofar as this thesis seeks to work through the \\ implications of Theodor Adorno's work, I will situate \\ Weber's analysis in relation to the Frankfurt school. \\ There is indeed much to be found in Weber on the \\ themes of rationality and normativity. The Frankfurt \\ School, as exemplifed in Habermas'discussion of Max \\ Weber's theory of rationalization, has looked closely \\ at this. Habermas writes:
}

Thus Weber and Horkheimer agree in the fundamentals of their oddly ambivalent diagnosis of the present age.

a) The credibility of religious and metaphysical worldviews falls prey to a process of rationalization to which they owed their own development; in this respect, the Enlightenment critique of theology and ontology is rational, that is, understandable on internal grounds, and irreversible.

b) The second stage of rationalization after the overcoming of myth makes possible a modem consciousness that is determined by the differentiation of cultural value spheres with their own in- 
ner logics; this results in a subjectivization of faith and knowledge; art and morality are split off from claims to propositional truth, whereas science retains a practical relation only to purposive-rational action (and forfeits its relation to communicative practice).

c) Subjective reason functions as a tool for selfpreservation in a struggle in which those involved orient themselves to fundamentally irrational and irreconcilable "gods and demons." It is no longer able to bestow meaning; rather, it threatens the unity of the lifeworld, and, therewith, the integration of society.

d) As the power of socially integrative worldviews and the social solidarity they bring about are not simply irrational, the "splitting apart of the cultural realms" of science, morality, and art cannot count simply as rational, even though it is based on learning processes and thus on reason." 58

The epistemologies of Adorno and Habermas attempt to respond to this crisis of rationality. This thesis seeks to add a legal theory dimension to this debate.

Richard Swedberg, in his analysis of Weber's theory of law and economics, summarizes a shared moment between an economy of affirmation and economic rationality, showing that an economy (in our case a capitalist one) is itself framed within normative affirmations:

Since Weber's emphasis on calculability is at the heart of how he viewed the role of law in modern rational capitalism, it is important to try to specify what Weber meant by this term. First of all, modern rational capitalism has to fulfill a number of requirements to qualify as such, accord-

58 Supra note 20 at 350 . 
ing to Weber, and one of these is what he terms calculable law [...] Weber seems to have had especially three items in mind when he referred to calculability in this context: (1) that the legal text lends itself to prediction; (2) that the administration of the law is not arbitrary; and (3) that contracts are legally enforced. ${ }^{59}$

The calculability of capitalism is bound to a costbenefit analysis and wealth maximization. Wealth maximization relies on the capacity to find and refine sources of surplus value. The isolation of surplus value as something that is of obvious benefit is representative of a way of thinking that anchors itself both in its practical outcome, and in the manner in which it can transcend other competing values. ${ }^{60}$

59 Richard Swedberg, "Max Weber's Contribution to the Economic Sociology of Law" (2006) 2:1 Annual Review of Law and Social Science, online: <http://www.annualreviews.org.ezpprodl. hul. harvard.edu/doi/abs/10.1146/annurev.lawsocsci.2.081805. $105800>$ at 13 .

60 Richard Posner embraces the transcendent imaginary of wealth maximization in his Economics of Justice (Cambridge, MA: Harvard U Press, 1983) at 68: "Liberty is another value that can be grounded more firmly in wealth maximization, than in utilitarianism. It is the almost universal opinion of economists (including Marxist economists) that free markets, whatever objections can be made to them on grounds of equity, maximize a society's wealth. This is, to be sure, an empirical judgment, but it rests on firmer ground than the claim that free markets maximize happiness. Most of the conventional pieties - keeping promises, telling the truth, and the like - can also be derived from the wealth maximization principle. Adherence to these virtues facilitates transactions and so promotes trade and hence wealth by reducing the costs of policing markets through self-protection, detailed contracts, litigation, and so on. Even altruism (benevolence) is an economizing principle, because it can be a substitute for costly market and legal processes. And yet even the altruist might decide to sell his services to the highest bidder rather than donate them to the neediest supplicant. Because of the costs of determining need other than through willingness to pay, allocation by price may confer greater net benefits on the rest of society than allocation by 'need' or 'desert.' Allocation by price will 
If one seeks to use a given set of resources to produce even more of a desired outcome on a costbenefit analysis, and this is in fact what happens, it becomes plausible that the values thereby asserted have prevailed legitimately over others. Indeed, the predictable outcome of this calculation is itself capable of becoming a normative commodity. Thus, for example, the cost-benefit analysis that accompanies resource extraction is itself now a normative commodity that helps to perpetuate resource extraction.

Depending on the idea of surplus value to eliminate the need to legitimate actions, can lead to avoiding those transactions that cannot meet this simplifying criteria. The wealth maximization that is made possible does not take place in a vacuum. It is also used to set up the entire web of supply and demand. At some point not only is a dependency created upon the search for surplus value to attract the resources that brings it into being, but this may result in no longer having a diversity of justice resources to respond to any other type of expectation.

also result in a greater accumulation of wealth. This wealth can be given away in whole or in part-though again the altruist will not want to spend so much time screening applicants for charity that he greatly reduces his productive work and the benefits it confers on other people." 
Tangible resources have been diverted into producing surplus value and intangible resources - especialIy normative and epistemic resources - have been confined to instrumental reasoning. The available justice resources are the amalgam of both.

This backdrop also speaks to the kinds of justice claims that are thus structurally enabled or disabled. In the foregoing example, property rights understood as societal resource allocation overlap with economic rationality in an economy of affirmation. Such a constellation can exert justice claims perceived as legitimate, irrespective of its externalities, provided it is legally reproduced. Negative macro-justice consequences are discounted against economic freedom and (the perception of democratic) choice.

Legitimation independent of justice externalities downloads an alienated ${ }^{61}$ form of (misleadingly subjective) affirmation onto the individual. That is, despite the fact that both the individual and the society may be engaging in unsustainable acts, or produce openly destructive outcomes, the choice to do so is

\footnotetext{
61 Alienated in the sense that the lack of accountability towards aggregate justice considerations is promoted as the locus for the allowed expression of private irrationality.
} 
embraced as a justice claim. ${ }^{62}$

The ability to colonize the means of reproduction of the economy of affirmation (in relation to normative horizons and the legal paradigm) may be key to accounting for the co-existence between advances in epistemic enabling (increases in both rationalization and knowledge) and the inconsequential impact this can have on preventing macro-justice failures. ${ }^{63}$

\section{As I will show, accounting for justice alterity} and indeterminacy ${ }^{64}$ requires resourcing ${ }^{65}$ the processes

\footnotetext{
62 No better example of this can found than Sarah Palin's campaign based on the slogan "Drill, Baby, Drill." This is particularly so after the Deepwater Horizon oil spill. See generally, Geoffrey Dunn, The Lies of Sarah Palin: the Untold Story behind Her Relentless Quest for Power (New York: St. Martin's Press, 2011) at $211 \mathrm{ff}$.

63 References in this text to the conventional legal paradigm mean the understanding of the law as a product of theory. This is not to assert that this paradigm is substantively uniform or selfunderstood, but rather that the paradigm is reproduced using widely accepted methodologies dependent on forms of affirmative rationality. The limitations of this rationality are explored throughout this thesis. Natural law and positive law theories are paradigmatic legal narratives not only because of their longstanding contribution to what we understand the law to be, but also because of the widespread acceptance of the framing they both prioritize. As explored in this thesis, each framing itself creates a threshold behind which it is impossible to slip, without engendering a crisis of legitimacy. In this sense, natural law and positive law theories have become as necessary to our understanding of the legal as any practice related to it.

64 Justice alterity, described in detail using the examples of

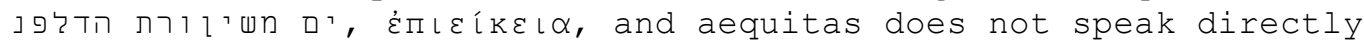
to what might be called fantasies of sovereignty over others and over the future. Rather, justice alterity has to do with forms of right that are outside our possible conception of control over others and the future. Alterity to the given means also the acknowledgement of what is beyond satisfying a right that is within our immediate grasp or conceptualization. Whereas justice alterity refers to what is beyond the horizon of current justice claims, indeterminacy refers to the emergent properties of changing social relations that cannot be predicted in advance. Any in-
} 
of judgment surrounding them, and not just specific outcomes. This means internalizing the liability to justice alterity and indeterminacy. Consequently, resourcing economic and normative macro-transformation requires a method for shifting subjectivity, ${ }^{6}$ " which includes socializing the cost of externalities such that individuals can make sustainable choices without assuming disproportionate risks (including those discussed below under the concept of disappointment ${ }^{0 / 1}$ ).

The concept of justice resources is intricately connected to the economy of affirmation. Tangible resources are meant here generally as things that are consumed or needed in real time towards a valued end. ${ }^{67}$ Resource allocation within an economy is classically understood as "the choices made about how scarce factors of production should be used [...]. It is the fact that resources are scarce that leads to the need for allocation."68 An economy of affirmation asserts limits

determinate social transformation will produce further impetus toward justice alterity, but there is no point of alignment between a future emergent state of social relations and current justice alterity.

65 In this sense resourcing is linked to its old French etymological origin, re(s)sourdre to rise again.

66 The concept of "legacy subjectivity" is discussed in the next section.

67 Diamond, supra note 49 at 28.

68 Evan Davis, RE Baxter \& Graham Bannock, The Penguin Dictionary of Economics, 7th ed (London: Penguin, 2003) at 333. 
on the capacity to engage alterity or emancipation as a constituent part of its justice claim.

For example, efforts at wealth maximization habitually invent profit by externalizing and downloading costs onto individual economic actors, or on that which is least capable of agency, often the environment. An economic order that is not extrinsically constrained will seek greater efficiencies at the expense of such de-resourcing and downloading. The race to the bottom $^{69}$ is a justice aggregate and justice alterity resourcing failure. This downloads antinomical burdens onto individuals and results systemically in overloading them and producing complicity in their own disabling. Subjectivity becomes inextricably linked to systemic justice externalities. ${ }^{70}$

\section{Antinomical Overburdening and Legacy Subjectivity}

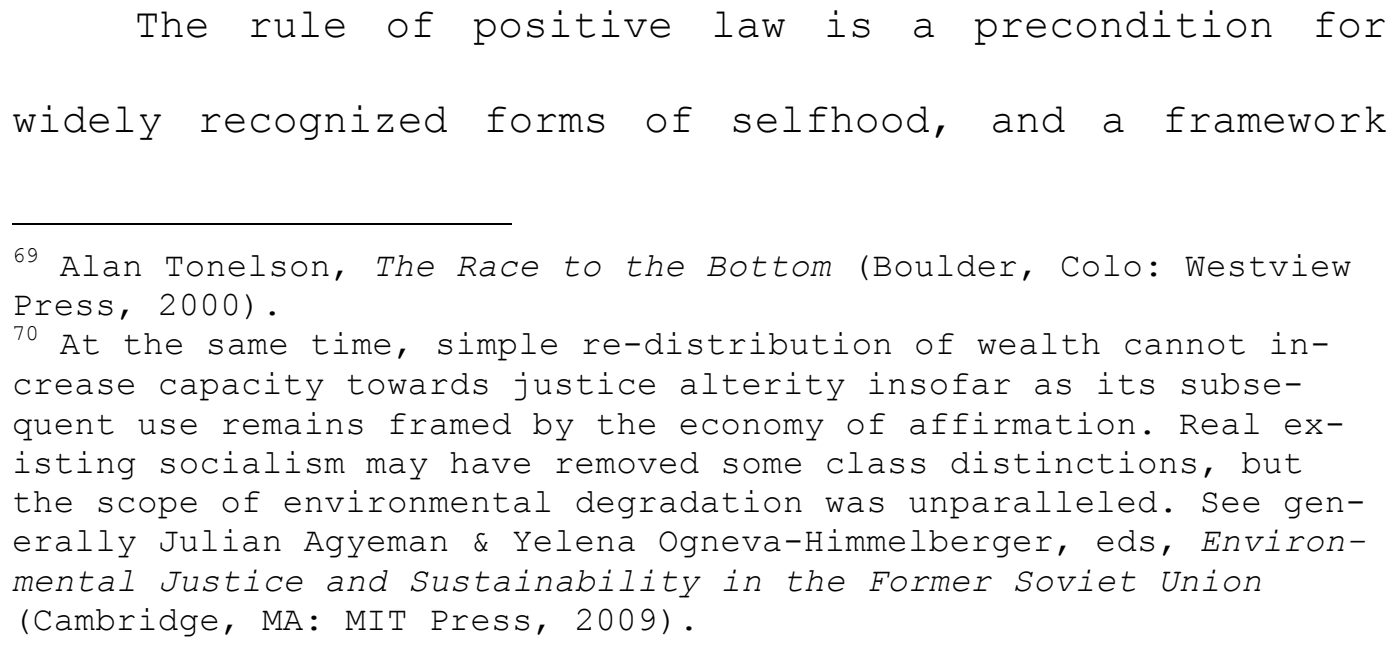


for the recognition of the clams of others. However, the rule of law could mean that we arrive at a wholly illegitimate outcome. ${ }^{71}$ This paradox produces a paradigmatic antinomical burden, i.e. having to provide resources for mutually exclusive outcomes.

On the one hand, legitimacy can depend on maintaining and transforming the existing economy of affirmation from within (a process I will call "intrinsic" transformation). On the other hand, transformation requires supplanting it with another (a process I will call "extrinsic" transformation).

The antinomical burden caused by the need for law and the need to exceed its limitations also plays itself out within the horizon of individual lives. Many affirmative legal norms are reproduced without effective choice. These investments (and the expectations

\footnotetext{
71 In "The Impossibility of the Rule of Law" (1999) 19 Oxford J L Studies 1, Timothy Endicott also underscores the antinomical character of the rule of law. According to Endicott (at 2), despite having no one unified meaning, the concept of the rule of law can be generally graspable as an ideal "when the life of the community is governed by law. So the rule of law can be opposed to anarchy, in which the life of the community is not governed. The rule of law can also be opposed to arbitrary government. So Aristotle wrote that it was better for the law to rule, than for any one of the citizens to rule." (footnotes omitted). Dicey's influential definition can also be helpful to ground the concept here: (1) the supremacy of regular law as opposed to arbitrary power; (2) equality before the law of all persons and classes, including government officials; and, (3) the incorporation of constitutional law as a binding part of the ordinary law of the land. Albert Venn Dicey, Introduction to the Study of the Law of the Constitution 3d ed (London: MacMillan, 1889) at 190-4.
} 
that they create) are the basis for the concept of legacy subjectivity

The legacy of the existing economy of affirmation generates its own legal subject. No matter how enabled or resourced we may or may not be, when faced with the necessity for transformation, we are situated within contingent investments that are part of us. ${ }^{72}$

Legacy subjectivity is not understood here to mean only external justice affirmations, for example, equality before the law, or due process. It is interdependent with our psychological-cognitive-normative self-understanding, which can be called its constitutive subjectivity, a concept that will be explored later in the text. ${ }^{73}$ Legacy subjectivity itself, is a representative antinomical justice burden within constitutive subjectivity.

The logical consequence of this is that social transformation can only be articulated through the enabling of the very identity, the aggregate of those external and internal nodes that taken together iterate a given moment of human consciousness, which pre-

\footnotetext{
72 Polemically expressed, legacy subjectivity can induce an individual to be epistemically disabled to the point that one is fully justified in advancing one's own destruction and that of future generations.

73 See infra Constitutive Subjectivity at 250.
} 
vents it. This means that transformation can require both the resourcing of the persistence of legacy subjectivity as well as its overcoming, without falling into the trap of incrementalism. ${ }^{74}$

Conventional conceptualizations of the rule of law are in negative tension with emancipatory justice claims, and the transformation of legal subjectivity that they would require. ${ }^{75}$ For example, the property right to the computer I am writing on has great affirmative solidity in comparison with the claim against it that could arise from its exploitation of non-renewable resources or its future generation of ewaste.

There would be little consensus in contemporary democratic society around the reversal of this normative priority; that is, in favour of the dependency

\footnotetext{
74 If legacy claims that resist social transformation are not themselves acknowledged and given significance, they will simply become fulcrums of resistance to change that will contribute ultimately to sharpening the injustices produced in the name of emancipation. A significant moment in the failure of twentieth century "revolutions" was conceptual blindness to the significance that these antinomical burdens have for social transformation. The Bolsheviks radically negated legacy subjectivity to the point of genocide. The failure of this to produce a substantively transformed individual is repeatedly reflected in efforts to address legacy justice claims, such as the New Economical Plan (NEP). See generally, VN Bandera, "New Economic Policy (NEP) as an Economic Policy" (1963) $71 \mathrm{~J}$ Pol Ec 3. Later in the thesis, the concept of disappointment ${ }^{0 / 1}$ is further theorized in relation to the work of Theodor Adorno: see infra at pp. 260-272.

75 This is particularly the case when procedural safeguards are so elaborate as to embed rights protecting micro-justice claims that conflict with macro-justice claims.
} 
and defeasibility of any form of exclusive property use upon prior, trumping protection of non-renewable resources. The justice externalities of my private property use are perceived as internalized by society and legitimated by legacy subjectivity interdependent with its economy of affirmation.

Taking the example further, what effectual responses could be made to contemporary society if indeed it is asserting its legacy subjectivity so as to eliminate by its action or inaction the capacity for future generations ever to produce justice outcomes other than those now being imposed?

If the primary legitimacy threshold operating in contemporary society restricts justice claims to those recognized within its economy of affirmation, then its law will be the means by which justice externalities are imposed on future generations or other societies. Emancipatory justice claims asserted against such hegemony are at typically marginalized as antinomic or simply anomic. ${ }^{76}$

76 In order to gain any purchase alterior claims require grounding in a countervailing economy of affirmation - such as that of aboriginal peoples. This normative phenomenon is explored in Chapter 4, below, where I canvass two cases in which the supreme court of Canada was on the threshold of using fiduciary obligations to engage with macro-normative claims in connection with Aboriginal peoples. See generally Roderick Macdonald, "Recognizing and Legitimating Aboriginal Justice: Implications for a Reconstruction 
The above example serves to illustrate the concept of a normative aporia, for which what Macdonald and Kleinhans call formal monist law can provide no resolution. ${ }^{77}$ It is impossible to force a normative collective to recognize and internalize justice incommensurabilities against its economy of affirmation while maintaining its conviction of possessing an autonomous constitutive subjectivity

Recall that the legitimacy of an economy of affirmation and legacy subjectivity is not predicated on their being objectively right (assuming counterfactually that such a determination is possible), but merely on the fact that that they are collectively affirmed, and that this method of affirmation is identified with at the expense of the capacity to identify otherwise.

By arguing that such affirmation is based on ignoring externalities, one can prove nothing of relevance, because the underlying assumptions grounding legacy subjectivity - those constituting the normative/epistemic nexus of the economy of affirmation -

of Non-Aboriginal Legal Systems in Canada" in Royal Commission on Aboriginal Peoples, Aboriginal Peoples and the Justice System (Ottawa: Supply and Services Canada, 1993) at 232.

77 See generally, Roderick A Macdonald \& Martha-Marie Kleinhans, "What is a Critical Legal Pluralism" (1997) 12 Can J L \& Soc 25. 
are reproduced without any requirement to acknowledge and address externalities. If the role of argumentation discounted and normative transformation is simply imposed, "legitimate" resistance will result.

I argue that the ability of the predominant normative (and economic) order to replicate itself depends in large measure, not on the attributes of its specific ideological historical articulation, but rather on its ability to colonize the economy of affirmation and reproduce legacy subjectivity. ${ }^{78}$ According to this analysis, the law's legitimacy always relies on epis-

78 Formal law is generally taken to be the main modern societal normative order and to the degree that it enables economic transactions, can be seen as a predominant economic order as well. Talcott Parsons describes "the legal system" as follows "What we have been treating as the societal normative order comes very close to what is generally meant by the concept of law. Much discussion of the law stresses the criteria of bindingness and enforceability, associating law primarily with government and the state. Other lines of analysis stress the consensual elements in the normative validity of law, a theme which permits emphasis on the importance of its moral legitimation. We treat law as the general normative code regulating action of, and defining the situation for, the member units of a society. It is comprised of the components just reviewed integrated into a single system." Talcott Parsons, The System of Modern Societies (Englewood Cliffs: Prentice-Hall, 1971) at 18. Parsons too focuses on the capacity of an economy of affirmation - what he would call a complex social system - to reproduce itself, what he would call its "latency": see Talcott Parsons, "On the Concept of ValueCommitments" (1968) 38:2 Sociological Inquiry 135 where the general outlines of his social theory are set out. However, because much of his focus is upon social reproduction, he detects within the fiduciary function only its contribution to the "patternmaintenance" of moral commitments and does not relate it to the processes of differentiation, adaptive upgrading, inclusion and value upgrading that for him characterize social evolution: see Talcott Parsons, The System of Modern Societies ibid. at 11 and 26-7. The focus of this thesis, by contrast, using Parsonian language, is on the connection between value breakdown (rather than value commitment) and the fiduciary role. 
temological constraints, on the limits on knowledge that are reproduced within an economy of affirmation. Law is always thus also the result of a normative/epistemological de-resourcing.

There can be no macro-normative transformation without a parallel epistemic shift. As Adorno and Horkheimer write:

The principle of immanence, the explanation of every event as repetition, that the Enlightenment upholds against mythic imagination, is the principle of myth itself. That arid wisdom that holds there is nothing new under the sun, because all the pieces in the meaningless game have been played, and all the great thoughts have already been thought, and because all possible discoveries can be construed in advance and all men are decided on adaptation as the means to selfpreservation - that dry sagacity merely reproduces the fantastic wisdom that it supposedly rejects: the sanction of fate that in retribution relentlessly remakes what has already been. What was different is equalized. That is the verdict which critically determines the limits of possible experience. The identity of everything with everything else is paid for in that nothing may at the same time be identical with itself. Enlightenment dissolves the injustice of the old inequality - unmediated lordship and mastery but at the same time perpetuates it in universal mediation, in the relation of any one existent to any other. ${ }^{79}$

79 A central theme of Horkheimer and Adorno's inquiry was the antinomy between rationality and barbarism. This leitmotif was extensively explored in the Dialectic of Enlightenment supra note 28. See also Max Horkheimer, Eclipse of Reason (New York: Continuum, 1985), Critique of Instrumental Reason, translated by Matthew O'Connell (London, Verso 2012). Horkheimer and Adorno's work provides the theoretical backdrop for the focus in this thesis on the relationship between an emancipatory claim and justice alterity. Whereas, Horkheimer and Adorno saw this antinomy as betokening a suppressed truth regarding the myth of progress (also in 
The other-regarding necessary to internalize the costs of a greater and continuous integration of justice alterity $^{80}$ will be shown to be irreconcilable with notions of legal causality.

To see the process of potential transformation as requiring an otherness outside the scope of the current economy of affirmation, or even its future trajectory, produces deep ambivalence. ${ }^{81}$ An open-ended justice imaginary, always beyond the horizon of the given, can easily be home to any form of moral vanity and emancipatory aesthetic. ${ }^{82}$

An intrinsic projection of a justice otherness to come (that is, derived from the refinement and understanding of the existing), may legitimate only the extension of existing claims, effectively blocking

response to the Holocaust), this thesis undertakes to explore how this antinomy in and for itself relates to justice. Max Horkheimer \& Theodor W Adorno, supra note 28 at 8 .

80 As Newman points out, "[e] thical advances in the law originate outside the established legal order, and relief from the harsh effects of the rules of law in particular cases must come from a source external to the law itself." See Ralph A Newman, "The Place and Function of Pure Equity in the Structure of Law" (1964) 16 Hastings LJ 401 at 407. This is a plain speech expression of the constellational critical role of justice alterity. Antinomical overburdening regularly leads to a justice resource crisis. It is the societal categorization of this crisis that an otherregarding macro-normative transformation would impact on.

81 Ambivalence defined here figuratively as the "the coexistence in one person of contradictory emotions or attitudes [...] towards a person or thing." See OED, supra note 15.

82 It is not accident that all forms of ideology, regardless of their moral bankruptcy, cloak themselves in the language and aesthetics of emancipation. 
transcendent transformation. ${ }^{83}$ On the other hand, to require a critical epistemology that is posttransformation, that is a projection of constitutive subjectivity before it can have appeared, and thus to embrace the antinomical burden head on, will likely be so resource-intensive as to be void ex ante. ${ }^{84}$

If the emancipatory threshold for legitimacy is set beyond what can be reasonably expected of a given economy of affirmation it will exhaust resources and produce emancipatory implosion, and the paralysis of disappointment ${ }^{0 / 1}$ explained below. However, if any incremental normative evolution may be inadequate to possible threats we confront, and the pursuit of revolution inevitably fraught with deep uncertainty and disappointment, what is left other than paralysis? This clash between parallel forms of paralysis can be understood as antinomical overburdening. On the one

83 This can be understood as reactionary transformation. Contrast this with Derrida's conception of a justice to come which deconstructs and confines the legitimacy of the given, including specifically the prevailing justice imaginaries. Jacques Derrida, Specters of Marx: The state of the Debt, the Work of Mourning, and the New International, translated by Peggy Kamuf (New York: Routledge, 1994). Accordingly, for example, revolutionary movements tend to reproduce, often in a more extreme and illegitimate form, the very structures they are seeking to overcome. They have not modelled another subjectivity required for the transformation, and simply wait for it to appear.

84 Indeed, this is the side of the antinomical burden to which this thesis is most prone. For a rich history of the German academic mandarin class see, Fritz K Ringer, Die Gelehrten: Der Niedergang der deutschen Mandarine 1890-1933 (Stuttgart: KlettCotta, 1983). 
hand, if the relationship between critical epistemology and justice is insufficiently developed, right will be more likely constituted using self-affirmational tropes and legacy subjectivity. ${ }^{85}$ Macro-normative transformation will then only result from crisis.

On the other hand, if the demands of an emancipatory epistemological/normative horizon are too great, the resulting implosion will exclude an aggregate justice outcome. ${ }^{86}$ In this case, the antinomical burden takes the form of a justice horizon that requires antinomical resolution beyond the limits of the actors involved, because they are already engaged in a process of transformation.

The analysis of antinomical burdens and their mediation can thus be understood as a substantial part of the process of transformation itself.

Such transformation must enable an intrinsic epistemic shift that delegitimates the reproduction of a

\footnotetext{
85 The normative strength of an economy of affirmation is its capacity for autopoiesis.

86 Slavoj žižek in Living in the End Times affirms this implosion as inescapable, and argues we should embrace the coming catastrophe in order to be enabled through it. Žižek's reading, a form of nihilistic humanism, reaches a diametrically opposite conclusion to the one proposed here. Žižek wills the consciousness of catastrophe so that the repression of its facticity can be overcome. I argue that the over-burdening inherent to such an embrace of catastrophe cannot produce anything other than a totalitarian outcome. Slavoj žižek, Living in the End Times (London: Verso, 2010).
} 
dominant economy of affirmation from within, while accounting for the legacy of justice claims it already contains. On the other hand, it must provide justice resources for extrinsic transformation that can account for disappointment ${ }^{/ 1}$, to which I now turn. I argue that sustainable macro-normative transformation must respond equally to intrinsic and extrinsic forms of antinomical overburdening.

\section{Emancipatory Disappointment ${ }^{0 / 1}$}

Sustainable emancipatory transformation by definition must meet the threshold of enabling individuals to reproduce it. This is a markedly non-economic process, through which each shift must gain continuing normative integration. ${ }^{87}$ To pour tangible and intangible resources into such a process is inherently illegitimate given the epistemic horizon that confines positive law and the contemporary surplus valuemaximizing economy of affirmation qua economic order. This illegitimacy manifests itself in the downloading of the burden of systemic failure onto the individual, while at the same time generating a threshold justice

87 I argue that revolutionary emancipatory narratives that are not accountable for their continuous antinomical burdening impose ex ante the likelihood of emancipatory implosion. 
claim with a nascent emancipatory dimension.

Essential to emancipation is the sense of alterity to the given. This projection implies an unsustainable tripartition: (i) that which cannot change and that will not "benefit" from emancipation; (ii) that which is experienced as an emancipatory moment (by definition unsustainable) $i^{88}$ and (iii) an ex post transformed state, which is both other to the outgoing, legacy subjectivity, but also other to the emancipatory moment itself. Setting aside (ii), the instance of emancipatory transformation itself, as temporally dislocated if not singular, we are left with two fundamental instances of emancipatory failure, what I henceforth refer to as structural emancipatory disappointmentss ${ }^{89}$. The neologism disappointment ${ }^{0 / 1}$ is used to underscore the inseparability and interdependence of the concepts.

Justice claims that cannot be taken up (because legacy subjectivity resists transformation or cannot

\footnotetext{
88 A person engaged in a process of radical transformation must focus resources on the immediacy of the situation to be mastered. The transformational moment can only be resourced by the sacrifice of other needs, or through the sacrifice of others. The revolutionary is outside the resource flows that prevail. Thus the transformational moment is one that is externally resourced and not self-sustaining.

89 Alain Badiou gives an albeit fetishized account of this singularity in Circonstances: Tome 5, L'hypothèse Communiste (Paris: Nouvelles Editions Lignes, 2009).
} 
be addressed by the transformation) engender what I term disappointment ${ }^{0}$. In this case, realized emancipatory claims are perceived as inadequate or simply invalid.

This type of emancipatory failure can be internalized. The sacrifices made toward embracing an emancipatory narrative end in alienation. One must admit that despite transformation, justice claims remain unresolved, because emancipatory actors themselves are the impediment to the intended transformation.

That is, despite the emancipatory claims being realized, emancipatory actors ${ }^{90}$ are not able to be transformed in the same measure as the external reality; such actors are alienated from the emancipatory outcome, and from their own realized emancipatory narratives. The repeated historical experience of the return of vestigial, pre-emancipatory elements, in a dystopic if not genocidal form, correspond in this theory with the greater susceptibility to disappointment ${ }^{0} \cdot{ }^{91}$

\footnotetext{
90 This term is used to refer both to individuals as well as to groups pursuing commensurate emancipatory claims.

91 This could also contribute to a greater theoretical understanding of why those who appear in need of emancipation are often very reluctant to engage it. The turn to the promise of less (perceived) disappointment can then be colonized as a form of emancipation itself.
} 
Thus, for example, if those who identify strongly with the emancipatory goal of transforming the economy so as to bring it within ecological boundaries were successful, they would soon discover that their own existing subjectivities remain unemancipated in myriad ways, leading to disappointment ${ }^{0}$. This would partly be revealed by their own inadequacy in light of the transformed society, but also by their inadequacy regarding the emergence of novel emancipatory claims.

By contrast, if the realized emancipatory claims become part of the broad societal economy of affirmation, another form of disappointment arises. Disaphpointment ${ }^{1}$ occurs when the ex post state ${ }^{92}$ displaces emancipatory claims by their post-transformation reification.

If the ex post state is, then the emancipation is potentially nothing other than that which was already possible before, and is already inadequate to produce the justice to come. Disappointment ${ }^{1}$ alienates the emancipatory actor from the transformed outcome by exposing its ontic uncertainty.

Whether beset with disappointment ${ }^{0}$ or disappointment $^{1}$, the justice horizon confronting the transforma92 The ex post state is replete with new shortcomings and incipient emancipatory claims. 
tional actor in each case lacks the alterity necessary to fulfill the requirements of an emancipatory justice moment. That is, the emancipatory actor is confronted by an outcome that discredits the transformative process. The legitimation deficit thus created can then be opportunistically filled by atavistic justice claims .

Potentially the most negative outcome is the collapse of these distinctions, with the perception that disappointment $^{0}$ (inadequacy of self to emancipation) and ex post disappointment ${ }^{1}$ (inadequacy of emancipation to self) are one and the same. That is to say, the types of disappointment are not capable of being distinguished and resourced appropriately. The net result is the general discrediting of social transformation. ${ }^{93}$

The conceptual pair of emancipatory Disappointment $^{0 / 1}$ helps to illuminates the structural interdependence of justice resources, justice alterity, emancipatory claims, and the liminal role of an economy of affirmation .

Emancipatory disappointment ${ }^{0 / 1}$ represents a para-

93 Thus, for example, we might well assert that an ecological transformation of the economy is at one and the same time beyond our capability as consumers and inevitably bound to produce a dystopian future. We thus become ensnared in stasis, reproducing and multiplying existing unsustainable outcomes. 
digmatic form of antinomical overburdening. Emancipatory claims have a counter-factual normative anchoring. Emancipatory actors can identify with them precisely because they are not realized. They can have the strength to trump all other justice claims in the matrix discussed above. And yet when they are realized, they produce by definition antinomical, or structurally mutually exclusive outcomes.

The normative/epistemic burdens here have both an economic and a threshold characteristic. Such antinomical states are by definition impervious to linear, causal rationality. They are not visible in economic terms. You cannot predict the cost of resourcing emancipatory actors through transformation, because the overlapping of antinomical disappointment ${ }^{0 / 1}$ outcomes $^{94}$ negates the affirmative anchoring, the economy of affirmation, of any starting narrative.

Without transformation, emancipatory claims are not realized. With transformation, antinomical burdening mandates resources that are aleatoric to any intended outcome. Thus the threshold, or unavoidable,

\footnotetext{
94 The term outcome means here a result that is produced by the specific interactions of factors described. In this instance, antinomical disappointment ${ }^{/ 1}$ outcomes would mean how the two components of disappointment ${ }^{0 / 1}$ specifically manifest in a given situation.
} 
characteristic of emancipatory disappointment ${ }^{0 / 1}$ is its rendering of the locus of antinomical overburdening within the transformational trajectory.

This links the non-economic dimension and the antinomical core of the realization of emancipatory claims, as well as providing for its metatheoretical basis. That is to say that the threshold characteristic of disappointment ${ }^{0 / 1}$ does not causally ground the non-economic dimension of emancipatory claims.

It provides the justice-theoretical frame from which this can be seen. This is important because disappointment ${ }^{/ 1}$ does not explain a particular state within an emancipatory trajectory. It is a relational concept, an analytical a priori, without being determinate.

\section{Conclusion: The Legal Subject Flees the Burden of Emancipation}

The forgoing is important to understanding the structural relationship between the de-resourcing of emancipatory alterity, and societal reliance on economies of affirmation to reproduce legitimacy. As I will explore in depth later on the text, the explicit or implicit release from (or from the risk of) antinomical overburdening is at the reactionary core of legal 
subjectivity

On this analysis, blind reliance on law to address macro-normative questions leads to the de-resourcing of emancipatory claims, and the concomitant acceptance of economies of affirmation that colonize and instrumentalize disappointment ${ }^{/ 1}$. The stronger the internalization of the rule of law, the greater is the barrier to justice alterity. Despite the seeming proliferation of choices in the face of macro-normative challenges, forms of justice alterity that would paradigmatically transform and thus burden or obligate affected actors are structurally occluded. ${ }^{95}$

Emancipatory justice theory re-integrates justice alterity as a sine qua non of legitimacy. This otherness does not stand alone as a blind pole of (revolutionary) affirmation, but rather embodies the very liminal sense on which the legitimacy of any justice aggregate depends. ${ }^{96}$

\footnotetext{
95 Even if "better knowledge" were available, this knowledge could not become normatively material if the right to exercise judgment according to it is coupled with unbearable risks downloaded onto the individual. In contrast to Sloterdijk's modeling of this as "enlightened false consciousness" in the Critique of Cynical Reason I argue that a primary method to ensure investment in a manifestly (self)destructive social construct is the societally imposed overlap of disappointment ${ }^{0}$ and disappointment ${ }^{1}$. See generally Peter Sloterdijk, Critique of Cynical Reason, translated by Michael Eldred (Minneapolis: University of Minnesota Press, 1987). 96 In distinction to the relationship of reason and myth modeled by Horkheimer and Adorno in the Dialectic of Enlightenment, supra
} 
note 28, I argue that the rationality associated with an economy of affirmation does not reach the quality of myth. Whereas myth may be seen to orient identification by offering an aesthetic form that can render antinomies, the atomization of subjectivity makes such an effect unnecessary. Instead of having myth to make sense of pain, of the disappointment ${ }^{0 / 1}$ produces an algodicy - a secular, de-mythologized account of pain that is enmeshed with an individual's experience of subjective freedom. See Sloterdijk, supra note 95 on the concept of algodicy. This concept is discussed at greater length in Chapter 4 in Defects of an Emancipatory Algodicy at 283 . 


\title{
Chapter 2: Sources of the Legal
}

\begin{abstract}
The purpose of this chapter is to situate the emancipatory claim in relation to the widely understood models of positive and natural law. I will look at how legal positivism has embodied conventional justice claims within the justice matrix sketched out in the previous chapter. ${ }^{97}$ After discussing positivism, I will turn to how natural law theorists have pursued metaphysical and subjective justice claims within the justice matrix.

An archetypal moment, despite methodological differences, for canonical writers like Bentham, Austin, Kelsen, and Hart, is being able to identify law, without identifying with it. The exclusive focus on law's positing, whether in an imperative source, a logical sine qua non (as in the Grundnorm), or in Hart's rule of recognition, immunizes law from the critique of inadequacy and contingency .
\end{abstract}

Legal positivism's primary justice claim is that

97 It is significant to note that the conceptual history of law is heterogeneous. Even the earliest conceptions defy simple definition. At the same time, this chapter will examine how the definition of law both poses emancipatory claims, and confines them. See Max Salomon Shellens, "Aristotle on Natural Law" (1959) 4 Natural L Forum 72 at 73. 
of empowering the law to be accountable to itself. ${ }^{98}$ The law gains in normative focus when it is sufficiently distinguishable to allow actors to recognize it as such. Positivists argue that such clarity systemically raises the threshold of law's legitimacy qua law.

Knowing as accurately as possible under what conditions posited law can be identified forces us to examine both what it means for the law to come into being this way, ${ }^{99}$ and how we are to judge the basis for effective adjudication. ${ }^{100}$ Positivism takes the significance of an economy of affirmation at face value. It draws traction from the willingness to accord norma-

\footnotetext{
98 See Joseph Raz, "Can There Be a Theory of Law?" SSRN eLibrary, online:

<http://papers.ssrn.com/sol3/papers. cfm?abstract id=1010287> at 14 ("Is it not our aim to study the nature of law, rather than our culture and its concept of law? Yes and no. We aim to improve our understanding of the nature of law. The law is a type of social institution, the type which is picked up - designated - by the concept of law. Hence in improving our understanding of the nature of law we assume an understanding of the concept of law, and improve it.") .

99 Raz describes this form of legal transparency as follows: "[a]ccounts of 'authority' attempt a double task. They are part of an attempt to make explicit elements of our common traditions: a highly prized activity in a culture which values selfawareness. At the same time such accounts take a position in the traditional debate about the precise connections between that and other concepts. They are partisan accounts furthering the cause of certain strands in the common tradition, by developing and producing new or newly recast arguments in their favour." See Joseph Raz, The Morality of Freedom (Oxford: Oxford University Press, 1988).

100 This is directly expressed in Legal formalism. See generally, A Scalia, "The Rule of Law as a Law of Rules" (1989) 56:4 U Chi L Rev 1175.
} 
tive substance to legal facticity.

In contrast to a common critique by natural law theorists, I will not attempt to dislodge positivism by arguing that it is blind to law's underlying values. Instead, I will show how the epistemic positioning of positivism structurally implies limitations on emancipatory justice claims. Thus positivist law does not fail because it excludes other law, but because it is a victim of its own success.

After the analysis of positive law, I will turn to natural law with a focus on the works of John Finnis and Robert Alexy. Whereas Finnis offers an affirmative theory, Alexy is at the threshold of providing a metatheory akin to what I undertake in this text. ${ }^{101}$ Alexy argues that positivism's own construction disallows it from discounting normative claims that reach beyond it. From his perspective, natural law is the quintessential subjective justice claim. Accounts of natural law seek to shift the normative frame of reference so as to render law's defi-

101 Alexy's natural law theory is in some respects a precursor of the analysis in this thesis, which by contrast eschews anchoring emancipatory claims at the subjective pole of the justice matrix. 
ciencies impossible. ${ }^{102}$ Whereas legal positivism seeks emancipation from antinomical overburdening, natural law seeks to address such overburdening using forms of transcendent(al) subjectivity. Natural law provides us with a bulwark against the injustice in ourselves by basing legitimacy on justice reposed in a universalized other, which could also be in us. From this commonality of other and self arises a de-subjectified and deontological conception of justice.

However, as I will undertake to show, both positivist and natural law theories fail to account for emancipatory claims, and depend on economies of affirmation constrained by legacy subjectivity, and the deresourcing and de-legitimation of justice alterity.

I will end the chapter with Duncan Kennedy's analysis of legal positivism and natural law. This will act as a bridge to the analysis of how fiduciary obligations can be understood already to encompass modes of legal understanding that transcend the limitations of the law as explored here.

102 In contrast to equity, which we will explore in the next chapter, natural law does not seek to balance or correct normative deficiencies arising from the operation of law. See infra at 154. 


\section{Legal Positivism}

Legal positivism, in one of its earliest articulations, was born of the desire to disaggregate natural and moral insights. Hume's famous observation of the elision between apodictic and normative assertions provides a backdrop to the positivist objective:

I cannot forbear adding to these reasonings an observation, which may, perhaps, be found of some importance. In every system of morality which I have hitherto met with, I have always remarked, that the author proceeds for some time in the ordinary way of reasoning, and establishes the being of a God, or makes observations concerning human affairs; when of a sudden I am surprised to find, that instead of the usual copulations of propositions, is, and is not, I meet with no proposition that is not connected with an ought, or an ought not. This change is imperceptible; but is, however, of the last consequence. For as this ought, or ought not, expresses some new relation or affirmation, it is necessary that it should be observed and explained; and at the same time that a reason should be given, for what seems altogether inconceivable, how this new relation can be a deduction from others, which are entirely different from it. But as authors do not commonly use this precaution, I shall presume to recommend it to the readers; and am persuaded, that this small attention would subvert all the vulgar systems of morality, and let us see that the distinction of vice and virtue is not founded merely on the relations of objects, nor is perceived by reason. ${ }^{103}$

The core of Hume's assertion is that normative claims cannot be the product of reason. This had great sig-

103 David Hume, An Inquiry Concerning Human Understanding (Upper Saddle River, NJ: Prentice Hall, 1997) at 257. 
nificance for the establishment of a "science"104 of law, distinct from that of ethics or morality.

I argue that there are two broad frames for theories of positive law, depending on how absolute or contingent the prioritizing of justice claims is. The distinction turns on whether the positivist model in question affirms or enunciates values that are open to critique or reformulation. In this sense, legal positivism cannot be reduced to legal formalism. Positivism can serve reactionary or radical ends. ${ }^{105}$

Closed, stipulative definitions satisfy their own criteria when they can generate reasoning sufficient to make the causality of arguments based on them ex-

104 John Austin championed analytical jurisprudence in which the law was to be an object of "scientific" study. See John Austin, Lectures on Jurisprudence, 3d ed (London: J. Murray, 1869) at 220 ("The existence of law is one thing; its merit or demerit is another. Whether it be or be not is one enquiry; whether it be or be not conformable to an assumed standard, is a different enquiry. A law, which actually exists, is a law, though we happen to dislike it, or though it vary from the text, by which we regulate our approbation and disapprobation. This truth, when formally announced as an abstract proposition, is so simple and glaring that it seems idle to insist upon it. But simple and glaring as it is, when enunciated in abstract expressions the enumeration of the instances in which it has been forgotten would fill a volume".).

105 See Peter Koller, "The Concept of Law and Its Conceptions" (2006) 19:2 Ratio Juris 180 at 188 ("A 'weak legal positivism' is a positivist legal theory [...] which interprets the presumed separation of law and morality in the weak sense that the law, though not necessarily linked to morality, may contingently include moral requirements. The best example of this view is the theory advocated by Jules Coleman, called 'Inclusive Positivism' [...]".). See Jules Coleman, The Practice of Principle: In Defense of a Pragmatist Approach to Legal Theory (Oxford: Oxford University Press, 2001). 
clusive (thus tending more towards a deontological outcome). ${ }^{106}$ Conventional closed positivism stresses that posited law as law is not open to question for its failure to reflect ethical or moral principles. The existence of the law should not be subject to critique; its positing gives it sufficient identity and recognition to fulfill all the requirements for being law.

In contrast, an open positivist account would recognize the law subject to teleological considerations; i.e. whether the law conforms to recognized rules of creation. An emancipatory, open positivist account recognizes the act of law's successful positing, but makes no normative claim beyond that; the law enjoys no normative primacy. The law could change radically, unhindered by the fact of its positing. ${ }^{107}$

Open and closed positivism can be mapped on to what Stephen Perry termed substantive and methodologi-

\footnotetext{
106 At the risk of muddying the waters, I use the term "exclusive", which tends to be used by positivists themselves to reflect common sense or self-evidence. But their usage only captures part of what I mean here, since I am referring as well to the process by which the economy of affirmation is circumscribed and rendered opaque. By way of illustration, see generally Joseph Raz, The Authority of Law: Essays on Law and Morality (Oxford: Oxford University Press, 2009).

107 Auguste Comte's foundational work on positivism illustrates that indeed it could be and was accompanied by an emancipatory program. See Auguste Comte, System of Positive Polity, translated by John Henry Bridges (Bristol: Thoemmes, 2001).
} 
cal positivism. ${ }^{108}$ Whereas substantive legal positivism may have an "open" or "closed" characteristic, methodological positivism is emblematic of a closed ethos. Methodological legal positivism is the view that legal theory can and should offer a normatively neutral description of a particular social phenomenon, namely law. Methodological positivism holds, we might say, not that there is no necessary connection between morality and law, but rather that there is no connection, necessary or otherwise, between morality and legal theory. We do not need to look at the justice implications of a law to identify it as such.

Substantive legal positivism asserts in contrast, that there is no necessary connection between morality and the content of law. As we have seen, this can mean that the discussion stops there. The law is the law, the discussion is closed once its existence is determined. On the other hand, the fact of the law can also mean that it is merely one of any number of iterations, all of which are open to being as much law as the current one.

The significance of these distinctions will become clear as we examine the types of emancipatory claims 108 Stephen Perry, "Hart's Methodological Positivism" (1998) 4:04 Legal Theory 427 . 
that are recognized or discredited, depending on the underlying relationship to the justice aggregate and the conceptual model affirmed.

Bentham provides a good starting point for an analysis of legal positivism because of the candour with which he combines heterogeneous normative and theoretical tangents. Despite his expressed intent to base his arguments on empirical elements, Bentham's argumentation uses a wide-ranging assemblage of justice claims.

The following analysis will briefly show how the concepts introduced in this text can illuminate Bentham's justice claims and epistemic scope, as well as how corresponding categories of recognition or exclusion are reproduced.

There are primarily two sides to what I characterize as Bentham's open, substantive positivism: the reduction of law to a provisional form of normative affirmation, subject to change (and herein lies his imperativism); and a utilitarian normative unavoidability (eudaemonic maximization) the non-observance of which is per se illegitimate.

The difference between not obeying the law and not maximizing utility is that in the former case 
there is the presumption that the individual is doing this at his or her own risk in defiance of command, whereas in the latter case the individual is incapable of being a legitimate legal subject. Strictly speaking, for Bentham the latter case is non-law rather than breach of law.

Revealing the centrality his emancipatory ethos, Bentham acknowledges his debt to Hume, who in the Treatise on Human Nature,

[...] brought to light - how apt men have been, on questions belonging to any part of the field of Ethics, to shift backwards and forwards, and apparently without their perceiving it, from the question, what has been done, to the question, what ought to be done, and vice versa: more especially from the former of these points to the other. ${ }^{109}$

The fact that any given law exists does not make an argument for its normative determinacy. Hart ${ }^{110}$ ob-

109 Jeremy Bentham, Chrestomathia (London: Messrs Payne and Foss, and $R$ Hunter, 1816) at 3 [emphasis in original].

110 See P Schofield, "Jeremy Bentham, the Principle of Utility, and Legal Positivism" (2003) 56:1 Current Legal Problems 1 at 37-38 ("According to Hart, Bentham was engaged in an enterprise which was, in respect of providing a morally neutral description of a legal system, identical with his own, albeit Bentham in his adoption of an imperative theory of law was unable to accomplish the objective with the same degree of success. Take, for instance, Hart's statement that Bentham regarded the task of universal expository jurisprudence to be the exposition of the ideas annexed to a short list of terms such as 'right' and 'law'. Hart continues: 'Quite frequently and explicitly, [Bentham] departed from usage in order to construct a meaning for a term which, while generally coinciding with usage and furnishing an explanation of its main trends, would not only be clear, but would pick out and collect clusters of features frequently recurrent in the life of a legal system, to which it was important to attend for some 
serves:

In legal theory Bentham's sharp severance in the Fragment [on Government] between law as it is and law as it ought to be and his insistence that the foundations of a legal system are properly described in the morally neutral terms of a general habit of obedience opened the long positivist tradition in English jurisprudence. ${ }^{111}$

For Hart, Jeremy Bentham"12 expounded a "calculatedly neutral approach to definition of legal and social phenomena [that] is now familiar to us, but when Bentham applied it to the law it was new, shocking and a tonic for reformers."113 Hart's account stressed two dimensions of Bentham's positivism, the imperativist theory of law, viz. that law is the result of command; and that law had no necessary or conceptual connection with morality. ${ }^{114}$ But this portrayal only speaks to one facet of Bentham's project. ${ }^{115}$

Bentham is understood, largely through Hart's in-

statable theoretical and practicable purpose'. This may be an accurate description of Hart's own approach, but it does not capture the essence of Bentham's approach.").

111 John Rawls \& HLA Hart, Essays on Bentham: Studies in Jurisprudence and Political Theory (Oxford: Clarendon Press, 1982) at 53. See also Richard A Cosgrove, Scholars of the Law: English Jurisprudence from Blackstone to Hart (New York: New York University Press, 1996).

112 Jeremy Bentham, A Comment on the Commentaries and A Fragment on Government (Oxford: Oxford University Press, 2009).

113 Rawls \& Hart, supra note 111 at 17-18.

114 Ibid.

115 See Imer B Flores \& Jorge Luis Fabra, "50th Anniversary of Hart's the Concept of Law" (2011) SSRN eLibrary, online:

<http://papers.ssrn.com/sol3/papers.cfm?abstract id=2015063> "([T]he establishment of a law may be spoken of as a fact, at least for the purpose of distinguishing from any consideration that may be offered as a reason for such law".). 
terpretation, to support both substantive and methodological positivism. My account will stress Bentham's open, substantive positivism. As to imperativism, which I will touch on in the next section, suffice it to say for now that Bentham's version of it emphasizes as much the fluidity as the fixity of commands.

Bentham's positivism is the result of trying to de-mythologize the law - to separate it from any foundational normative narrative - and instead to render it subject to a form of egalitarian and accessible normative transformation. Hart's influential reading does not take Bentham's emancipatory ethos into account.

Philip Schofield stresses that, rather than regarding substantive legal positivism and methodological legal positivism as separate doctrines, Hart appears to conflate them in his statement that Bentham "insisted on a precise, morally neutral vocabulary for use in the discussion of law and politics as part of a larger concern to sharpen men's awareness [...] of the distinction between what is and what ought to be."116 Bentham's positivism seen in this light does not support a "closed" interpretation of the form that Hart

116 Supra note 111 at 34 . 
advances. ${ }^{117}$

This calls into question subsequent articulations of positivism that rely on Bentham's hypostasis of law. By obscuring the scope of the emancipatory claim, successive iterations of legal positivism contradict their purportedly neutral, factual modeling of the law. The ideological framing of legal positivism, in light of the effect this has on emancipatory claims, is not a disinterested act. Law's normative legitimacy (for Bentham, its utility) depends on the factual ${ }^{118}$ outcome of greater aggregate pleasure. ${ }^{119}$ Bentham's theory of justice is

117 See Jeremy Bentham, The Works of Jeremy Bentham: vol I (Edinburgh: W. Tait, 1843) at 230 ("Thus much is certain; that a system that is never to be censured, will never be improved: that if nothing is ever to be found fault with, nothing will ever be mended: and that a resolution to justify every thing at any rate, and to disapprove of nothing, is a resolution which, pursued in future, must stand as an effectual bar to all the additional happiness we can ever hope for; pursued hitherto would have robbed us of that share of happiness which we enjoy already".).

118 See Jeremy Bentham \& Philip Schofield, Selected Writings: Jeremy Bentham (New Haven: Yale University Press, 2011) at 443 ("The question of utility is a question not of sounds but of sensations: it depends not upon your choosing to allow or to refuse to this or that class of occupants this or that name, but upon the feelings of men of all classes.") .

119 Bentham himself later distanced himself from being termed a utilitarian: "By the appearance of the second edition of An Introduction to the Principles of Morals and Legislation in 1823, Bentham had come to prefer the phrase 'the greatest happiness principle' or 'the greatest felicity principle' instead of 'the principle of utility'. The term 'utility' did not sufficiently convey the idea of happiness." See ibid at 442 . 
predicated on the fact of net eudaemonia. ${ }^{120}$ This requires the questioning of all existing norms, particularly positive law's assumed moral or ethical underpinnings. To change the world for the better, one has to remove the ballast of normative mystification.

Bentham's concept of pleasure is difficult to pin down. ${ }^{121}$ On the one hand he locates it in the facticity of an observable physical state. On the other hand, the normative force of the pleasure principle is within the realm of judgment, reflecting a calculable value. ${ }^{122}$

That pleasure is measurable or calculable for Ben-

120 I choose to interpret Bentham's concept of the greatest possible aggregate pleasure achieved as being all encompassing, although Bentham's own definition lacks this dimension.

121 See generally Mary Peter Mack, Jeremy Bentham: An Odyssey of Ideas (New York: Columbia University Press, 1963); Paul McReynolds, "The Motivational Psychology of Jeremy Bentham: II. Efforts toward Quantification and Classification" (1968) 4:4 Journal of the History of the Behavioral Sciences 349.

122 There has been much debate as to whether Bentham was the victim of a naturalistic fallacy. G E Moore, Principia Ethica (Mineola, NY: Dover Publications, 2004). This accusation has been refuted, notably in Amnon Goldworth, "Bentham's Concept of Pleasure: Its Relation to Fictitious Terms" (1972) 82:4 Ethics 334 ("Although much of Bentham's Utilitarianism has been dissected and explained, little or nothing has been recorded concerning the semantic status of Bentham's concept of pleasure, or of the relationship, for Bentham, between this concept and the concept of good. To my knowledge, only two books, John Wisdom's Interpretation and Analysis in Relation to Bentham's Theory of Definition, and C. K. Ogden's Bentham's Theory of Fictions, have dealt extensively with Bentham's theory of language. However, neither of these has included a study of the concept of pleasure. Contrariwise, those who have made some effort to interpret Bentham's concept of pleasure have failed either to notice or to discuss important implications to be drawn from his theory of language as it applies to the concept of pleasure."). See also Gerald J Postema, Bentham: Moral, Political, and Legal Philosophy (Aldershot, UK: Ashgate, 2002) at 51. 
tham is important to his understanding of the emancipatory. Bentham asserts that normative value is created when all the pleasure and pain produced "in all breasts that seem likely to be in any way affected by [the act]"123 is taken into account. Schofield summarizes his methodology as follows:

In short, it was the taking into account of the final "circumstance" by which the quantity or value of a pain or pleasure was to be measured, namely that of extent, that superadded a statement of moral fact to a statement of psychological fact. ${ }^{124}$

In principle all can engage in a calculation of aggregate pleasure and pain. Thus the normative foundations of law can be predictably and factually derived and come to substitute for any other foundational narrative. The law can be emancipated from its existing foundations. Bentham writes:

The idea of a Law has never yet been precisely settled: the conditions requisite to reduce the idea of a command so as to render it commensurate to that of a Law have never been ascertained. This task it is my purpose to attempt [...] my business therefore is not to remind the reader what is meant by a Law: for no one certain thing is as yet meant by a Law, but to declare what shall be meant by a Law. ${ }^{125}$

The significance of this shift is made clear in Bentham's unequivocal rejection of Blackstone's natural

123 Bentham \& Schofield, supra note 118 at 441 .

124 Schofield, supra note 110 at 28.

125 Jeremy Bentham, University College London Library, Bentham Papers, Box LXIX, fo 86, cited in Schofield, supra note 110 at 22. 
law/metaphysical legal model, ${ }^{126}$ which rested on "the law of nature and the law of revelation."127

Bentham has two concerns here. The first is that natural law was open to whimsical and idiosyncratic forms that would make it ill suited to accomplish any objectively defined task. Additionally, if an objectively legitimate law could be developed, it could only produce its attendant benefit if its recognition was not subject to the vagaries of conscience or legal myth. ${ }^{128}$

Instead of ensconcing positive law outside the bounds of any normative critique, it was Bentham's project to identify it as having been posited. The law thus isolated from a normative root could be analyzed according to its capacity in the present to satisfy other criteria. Whether the law had reacted to a circumstance in the past or settled on some rule said

126 See William Blackstone, The Commentaries of Sir William Blackstone (Chicago, IL: American Bar Association, 2009) at 41 ("This law of nature, being co-eval with mankind, and dictated by God himself, is of course superior in obligation to all other. It is binding over all the globe, in all countries, and at all times: no human laws are of any validity, if contrary to this; and such of them as are valid derive all their force, and all their authority, mediately or immediately from this original.").

127 Ibid.

128 Bentham writes, "[...] if, in a word, there be scarce any law whatever but what those who have not liked it have found, on some account or another, to be repugnant to some text of scripture; I see no remedy but that the natural tendency of such doctrine is to impel a man, by the force of conscience, to rise up in arms against any law whatever he happens not to like". See Bentham, supra note 117 at 287 . 
nothing to its capacity in the present to respond to the evolving needs of society.

Thus, Bentham's project is inseparable from the radicalism of his proto-emancipatory utilitarian project. Indeed, it is important to note that Bentham's positivism is not anchored at the conventional pole of the justice matrix. It is not the reproduction and stability of positive law as law that his conception seeks to enable.

On the contrary, he seeks its sweeping and ongoing change. If law is forbidden from the pretension of innately reflecting metaphysical (faith), subjective (universal reason), and even conventional (legal formalist) justice claims, the emancipatory claim can become the source of normative anchoring. By aiming to describe the law amorally, Bentham was opening up the question of normativity to that which is other than existing law.

However, Bentham's radicality is immobilized by the supremacy of his empirically driven concept of pleasure and pain. Bentham asserts that the utility principle should,

[...] preside over and govern, as it were, such arrangement as shall be made of the several institutions or combinations of institutions that compose 
the matter of this science [...] Governed in this manner, by a principle that is recognized by all men, the same arrangement that would serve for the jurisprudence of any one country, would serve with little variation for that of any other. Yet more. The mischievousness of a bad law would be detected, at least the utility of it would be rendered suspicious, by the difficulty of finding a place for it in such an arrangement: while, on the other hand, a technical arrangement is a sink that with equal facility will swallow any garbage that is thrown into it [...] The synopsis of such an arrangement would at once be a compendium of expository and of censorial Jurisprudence... Such a synopsis, in short, would be at once a map, and that an universal one, of jurisprudence as it is, and a slight, but comprehensive sketch of what it ought to be. ${ }^{129}$

Instead of the emancipatory ethos opening itself up to

the multiplicity and heterogeneity of human needs (which can produce pleasure or pain), Bentham stakes his entire project on the assertion of a factual happiness criterion. ${ }^{130}$ Justice will be rendered when the individual and the collective receive their due according to the principle of eudaemonic utility.

A timeless rejoinder to this can be found in socrates' response to Polemarchus' assertion that "it is just to give to each what is owed". ${ }^{131}$ Socrates' answer illustrates how justice involves addressing a multi-

129 Ibid at 237-38 [emphasis in original].

130 Bentham writes, "but except in so far as in some shape or other it leads to and is productive of well-being - a balance on the side of happiness - what is the value of all the knowledge in the world? - Just nothing." See ibid at 233.

131 Plato, The Republic, translated by Allan Bloom (New York: Basic Books, 1991) at 7 . 
plicity of claims:

But as to this very thing, justice, shall we so simply assert that it is the truth and giving back what a man has taken from another, or is to do these very things sometimes just and sometimes unjust? Take this case as an example of what I mean: everyone would surely say that if a man takes weapons from a friend when the latter is of sound mind, and the friend demands them back when he is mad, one shouldn't give back such things, and the man who gave them back would not be just, and moreover, one should not be willing to tell someone in this state the whole truth. ${ }^{132}$

Socrates chose the case of weapons to stress a macrojustice consideration within the miniature of the example. This displays what I would term the externalization of a justice burden. The creditor's apparent incapacity forces upon the debtor the consequences of judging that capacity. ${ }^{133}$

By contrast, Bentham's eudaemonic affirmation relies on the good derived from the existing state of an individual, and the aggregate of all such individual states. Bentham's describes the process of calculating aggregate collective pleasure and pain as follows:

To take an exact account then of the general tendency of any act, by which the interests of a community are affected, proceed as follows. Begin with any one person of those whose interests seem most immediately to be affected by it: and take an account,

132 Socrates contra Cephalus, Republic 331c.

133 This type of relationship to the non-obvious needs of another foreshadows fiduciary otherness that is the subject of chapter four of this thesis. 
Of the value of each distinguishable pleasure which appears to be produced by it [...]

Sum up all the values of all the pleasures on the one side, and those of all the pains on the other. The balance, if it be on the side of pleasure, will give the good tendency of the act upon the whole, with respect to the interests of that individual person; if on the side of pain, the bad tendency of it upon the whole.

Take an account of the number of persons whose interests appear to be concerned; and repeat the above process with respect to each. Sum up the numbers expressive of the degrees of good tendency, which the act has, with respect to each individual, in regard to whom the tendency of it is good upon the whole: do this again with respect to each individual, in regard to whom the tendency of it is good upon the whole: do this again with respect to each individual, in regard to whom the tendency of it is bad upon the whole. Take the balance which if on the side of pleasure, will give the general good tendency of the act, with respect to the total number or community of individuals concerned; if on the side of pain, the general evil tendency, with respect to the same community. ${ }^{134}$

Despite these limitations, Bentham does give a dramatic shift in meaning to Polemarchus' customary definition of justice. ${ }^{135}$ As opposed to asserting that everyone has a right to what they deserve (i.e. own, have earned, or are worthy of), Bentham substitutes a right to an unending process of individual and collective enabling of gratification.

Bentham did not believe that individuals are motivated by reason; rather the passions are the genuine

134 Bentham, supra note 117 at 15-16.

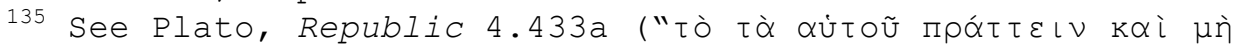

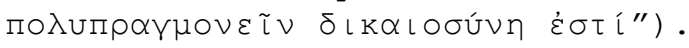


seat of choice (preference) and action (decision). A society that failed to construct itself around this insight would be depriving individuals of the only thing that could empirically matter to them. Thus Polemarchus' statement is read to mean that each individual owes to himself, and the collective owes to itself, the reproduction of a state of maximized (free) gratification

This empirical, factual quality of Bentham's model depends on the individual always freely choosing an outcome that will maximize happiness. A normative order thus legitimated would be the best of all worlds in the eyes of its citizens. The law's role would be to facilitate and ensure this outcome. Any other justice consideration would be a limitation on the legitimacy of the normative order because it would demand a sacrifice of the eudaemonic aggregate, and a loss of subjective (though in Bentham's eyes, objective) freedom .

Bentham's concept has as a consequence that happiness through the maximization of pleasure and the minimization of pain must be maintained at the expense of all values. Radical transformation is necessary, so long as the collective places the gratification of its 
passions before all other considerations.

This form of posited legalism encompasses a (radical) justice claim. It is however negated by Bentham's reliance on an economy of affirmation predicated on the avoidance of justice alterity and antinomical burdening. The emancipatory claim is reified within the confines of an autopoietic form of subjectivity, thereby making its justice externalities anonymous. In sum, the colonization of the emancipatory claim by a circumscribed form of subjectivity, coupled with the hypostasis of norms generated by the economy of affirmation, becomes the quintessence of the legal. Bentham's model is a prototype for the elision between an economy of affirmation - in his terms, the aggregate of calculable desire and motivation - and the law.

The autopoietic character of a gratificationseeking normativity depends on the exclusion of nonempirical, viz. non-possessory heterogeneous claims. That is, the kind of subject who would not seek to maximize pleasure and minimize pain cannot be recognized. The end point of Bentham's project is that we are all on the same page because we are convinced that we have gotten there without making any sacrifices; our collective gratification could not be greater. An- 
yone attempting to undermine such a state could have no $\operatorname{legitimacy} \cdot^{136}$

The utilitarian eudaemonic articulation would have to be imposed in such a way that competing, less material justice imaginaries or aggregate justice outcomes are precluded. ${ }^{137}$ Bentham's distinction between the Expositor and the Censor is significant here:

To the province of Expositor it belongs to explain to us what, as he supposes, the Law is: to that of the Censor, to observe to us what he thinks it ought to be. The former, therefore, is principally occupied in stating, or in inquiring after facts: the latter, in discussing reasons. The Expositor,

136 See Bentham \& Schofield, supra note 118 at 449 ("The principle of utility placed the question of the desirability of reform on a factual basis, whereas it was the mistake of the adherents of natural law, and of other nonutilitarian ethical standards, to claim that they had knowledge of right and wrong without any reference to facts. Bentham believed that, the 'mischievousness of a bad law' would be detected, at least the utility of it would be rendered suspicious, by the difficulty of finding a place for it in such an arrangement: while, on the other hand, a technical arrangement is a sink that with equal facility will swallow any garbage that is thrown into it."). Note that the test of Pareto efficiency - that an alternative state represents an improvement if it enhances the utility of at least one individual without diminishing that of others - has taken on precisely this legitimating quality in the economic literature. As Amartya Sen observed in his 1998 Nobel Prize lecture, "[a] good deal of [...] welfare economics restricts attention to 'Pareto efficiency' only (that is, only to making sure that no further Pareto improvements are possible). This criterion takes no interest whatever in distributional issues, which cannot be addressed without considering conflicts of interest and of preferences." See Amartya Sen, "The Possibility of Social Change" in Torsten Persson, ed, Nobel Lectures in Economic Sciences, 1996-2000 (London: World Scientific Pub Co Inc, 2003) at 183. Sen is acknowledging here the exclusion of a justice alterity from a utilitarian account of justice, and indeed locates the origin of such thinking in Bentham. See ibid at 181 .

137 Compare this to a real-socialist process of socialization in which an individual would gradually be brought to an abandonment of subjectivity towards a collective, non-individualized eudaemonic outcome. In this case other-regarding becomes the social currency, and self-regarding becomes the anomic ethos. 
keeping within his sphere, has no concern with any other faculties of the mind than the apprehension, the memory and the judgement: the latter, in virtue of these sentiments of pleasure or displeasure which he finds occasion to annex to the objects under his review, holds some intercourse with the affections. ${ }^{138}$

Accordingly, the task of the Expositor (i.e. the jurist), is to describe the actual determinations of legislators and judges, while that of the censor (i.e. the reformer) is to frame what ought to be done in the future in light of changing social affections - what we would today call values. ${ }^{139}$

The continuity of the law is guaranteed only on the basis of its momentary articulation of "utility". Bentham asserted:

For my part, I know not for what good reason it is that the merit of justifying a law when right, should be thought greater, than that of censuring it when wrong. Under a government of laws, what is the motto of a good citizen? To obey punctually; to censure freely. ${ }^{140}$

On the one hand, Bentham's emancipatory ethos liberates subjectivity to discover the primacy of a eudaemonic collective; on the other hand it limits such emancipation to a justice horizon locked within the epistemic borders of an economy of affirmation. In this sense, Bentham is an architect of enthroned lega-

138 Bentham, supra note 117 at 229 [emphasis in original].

139 Ibid at 230 .

140 Ibid. 
cy subjectivity.

Once justice is inseparable from the limits of an autopoietic self-regarding subjectivity, the consideration of other-regarding forms of justice, or even of the concept of the alterity of justice itself, is illegitimate. Bentham's methodology presages the "enlightened" hegemony of law.

This hegemony depends on an epistemic axis, the net affirmative surplus of which mirrors the economic concept of surplus value. Its plausibility replaces the question of substance, by allowing (and thus mandating) the privatization of other dimensions of subjective identification. Heterogeneity can be downloaded onto the individual and re-appears in diverse patterns of consumption and individualist materialist fetishization as the only socially sanctioned method for its expression. ${ }^{141}$

Bentham's outline for an implicit social contract concerning the limits of legitimacy, the extent of private choice and the operation of legal prerogative pre-empts other social contracts because it can be re-

\footnotetext{
141 See Habermas, supra note 20 at 246 ("Weber sees the sign of the age in the return of a new polytheism, in which the struggle among the gods takes on the depersonified, objectified form of an antagonism among irreducible orders of value and life. The rationalized world has become meaningless.").
} 
produced without the transaction costs associated with a fully other-regarding relationship. The otherregarding contained within the law that Bentham affirms is only towards a symmetrical other legal subject, viz. to oneself as the legal subject in another. The desire I recognize in myself I can recognize in another, and in aggregate, in and with all others.

Once collectives are reified by this autopoietic form of "legal subjectivity", an individual's need to have alternative forms of relationship is perceived as an illegitimate burden on the apotheosis of the selflegitimating, self-regarding self. This latter self would lose gratification if it adhered to any other ethos; such loss of gratification is itself a heretical act.

To summarize, the form of legal subjectivity that Bentham proposed reflects the evolution of the role of law towards collectively affirmed rational/economic gratification. This form of rationality reifies normativity and subjectivity into an economy of affirmation. ${ }^{142}$ The effectiveness of this channelling is a rationalization of a subjective justice claim and a lim-

142 See generally, Habermas ibid at 218-353. 
itation of the justice imaginary. ${ }^{143}$

The form of legal subjectivity inaugurated by Bentham reproduces this justice antinomy while producing at the same time a threshold justice moment, which I term an unavoidability ${ }^{144}$. Once Bentham's emancipatory ethos is epistemically/normatively embraced, any justice aggregate that refuses to account for these claims would always already be unjust when measured against it.

It is unavoidable for any further evolution of a justice imaginary, or for a deployed justice aggregate, to not account for historically articulated autopoietic emancipatory claims. Failure to do so can prima facie delegitimise any given normative ordering. Suppression of autopoietic justice claims is always at the risk of their being reasserted, irrelevant of the cost to the justice aggregate. The very structure of their reproduction bonds an economy of affirmation, a justice imaginary, an epistemic horizon, as

143 Weber's sociological analysis of law initially identifies a legal order by the fact that it serves to orient the real behavior of individuals. Weber writes, "an order will be called [...] law if it is guaranteed by the probability that physical or psychological coercion will be applied by a staff of people in order to bring about compliance or avenge violation". See Max Weber, Max Weber on Law in Economy and Society, translated by Max Rheinstein \& Edward Shils (New York: Simon and Schuster, 1954) at 34. 144 The German term is Nichthintergehbarkeit. The concept of unavoidability used in this chapter is discussed at greater length in Chapter 4. 
well as an unavoidable emancipatory justice claim. The resulting societal facticity is both a response to the challenges of antinomical burdening, as well an autopoietic barrier to their unrestrained consideration.

Bentham's legal positivist understanding is a challenge to any emancipatory project, not only because it reifies an emancipatory justice claim, but also because the threshold unavoidability of this claim requires inclusion at the risk of illegitimacy.

For example, Bentham's positivism could be taken up as part of a reform process. The law would appear to transform itself in line with people's needs. Yet if people's needs are recognized only if they reflect a surplus value maximizing subjectivity, the negotiation of the antinomies between existing law and future justice will be under-resourced.

Existing forms of subjectivity, irrelevant of their unsustainability, will be reified. On the other hand, if the transformational process attempts to do without the justice claims of legacy subjectivity, viz. those claims seeking a new trajectory for the maximization of utility, the persistence of such claims will cause another form of antinomical overburdening. In this sense the establishment of Bentham's 
eudaemonic unavoidability carries a deep ambivalence. Once established, it imposes a significant encumbrance on any future emancipatory trajectory. ${ }^{145}$

\title{
Post Imperativist Legal Posivitism
}

\author{
Whereas Bentham sought to ground law in empirical \\ facts, later positivists, notably Kelsen and Hart, \\ turned to the analysis of threshold moments of legiti- \\ mation outside an imperativist model. ${ }^{146}$ Post- \\ imperativist approaches retain and yet recast non-law \\ and breach of law by seeking to render the latter more \\ normatively "neutral" than it had been for Bentham. By \\ arguing that the law is not transcendent, post- \\ imperativist positivists distance the law from any \\ over-arching legitimation in two senses. The law is no \\ more than what it is, and the law does not have to be \\ 145 It is not so much that the justice claims contained within Ben- \\ tham's eudaemonism trump those of future emancipation. Rather, \\ Bentham's normative unavoidability impoverishes the epistemic \\ constellation needed to produce other-regarding judgments. \\ 146 Imperativist legal positivism has been subject to relentless \\ critique for its simplification of law. The most common question \\ is how imperativist approaches could account for many forms of \\ private law, i.e., contracts or wills, in which rules were set up \\ to allow private actors to order their affairs largely as they \\ wished. How could sovereign authority be seen as the moving force \\ of such pre-eminently private ordering? Parallel to this, modern \\ democracies do not exhibit the characteristic of showing defer- \\ ence to some authority outside the law. Elected representatives \\ are not above the law, and their authority is mandated by their \\ electorate and limited by constitutional restraints. For examples \\ of the discussion of imperativism, see Alexander Passerin d' En- \\ tréves, Natural Law: An Introduction to Legal Philosophy (New \\ Brunswick, NJ: Transaction Publishers, 1951) at 175; Ota Wein- \\ berger, "The Expressive Conception of Norms: An Impasse for the \\ Logic of Norms" 4 Law and Philosophy 165 (1985).
}


more than what it is.

One could argue that this is a form of unburdening of the law, so that it can be focused on the things it can do best. It also forces us to observe the law in complete isolation. Bentham's Expositor will have no accompanying Censor. All that we ask is: what is the factual context around the creation and adjudication of the law? This separation for the sake of greater clarity can produce its own kind of emancipatory outcome. The law is no longer subordinate to Bentham's utility-maximizing subjectivity. However, the creation of an emancipatory/epistemic unavoidability around law's normative neutrality may also result in the entrenchment of another economy of affirmation that also incapacitates the resourcing of justice alterity

In contrast to a criticism often raised, that because of its moral neutrality, post-imperativist legal positivism is disabled from preventing legal totalitarian excesses, ${ }^{147}$ I argue that the greater peril posed is its epistemic/normative disabling of emancipatory claims. Both Kelsen and Hart can be considered methodological positivists.

147 See generally, Lon L Fuller, "Positivism and Fidelity to Law: A Reply to Professor Hart" (1957) 71 Harv L Rev 630. 
Kelsen affirms a closed conventional framework. I will use the comparison with Kant's transcendental idealism to show how Kelsen's epistemic/normative model leads to the virtual exclusion of justice alterity. The analysis of Kelsen's Grundnorm will also advance the analysis of how conceptual methodologies in and of themselves are open to an emancipatory justice critique. Bentham's limitations can be uncovered by focusing on the role of legacy subjectivity in his emancipatory narrative. But deficits in Kelsen's positing of the law require a more metatheoretical approach to expose the interdependence between epistemic and normative ordering.

\section{Kelsen in the Shadow of Kant: Ex Ante Unavoidability}

Hans Kelsen responds to imperativist reductionism of law to command by developing threshold categories and genetic concepts for the recognition of the legal. He writes, "[l]aw is not, as it is sometimes said, a rule. It is a set of rules having the kind of unity we understand by a system". ${ }^{148}$ In addition to its systematic quality (the categorical threshold for the identification of the law), Kelsen argues that there will

\footnotetext{
148 Hans Kelsen, General Theory of Law and State (Clark, NJ: The Lawbook Exchange, 2007) at 3 .
} 
always be an underlying normative presumption, a normative unavoidability, which he calls the "basic norm" (Grundnorm).

The chain of affirmations surrounding a legal norm cannot be explained or grounded without it. ${ }^{149}$ The Grundnorm is required for the creation or reproduction of the concept of law itself. This type of ex ante epistemic/normative unavoidability is not unique to Kelsen's methodology. A brief comparison of Kelsen's approach with Kant's transcendental idealism allows us better to situate the effect of Kelsen's Grundnorm on emancipatory questions.

Kant's transcendental idealism ${ }^{150}$ asserts that phenomena are knowable to us only in so far as our capacities allow. They do not mean something in and of

149 A society could exist without a legal order, as we understand it. Kelsen admits that the recognition of the Grundnorm is noncompulsory: "The Pure Theory describes the positive law as an objectively valid order and states that this interpretation is possible only under the condition that a basic norm is presupposed [...]. The Pure Theory, thereby characterizes this interpretation as possible, not necessary, and presents the objective validity of positive law only as conditional-namely conditioned by the presupposed basic norm." See Hans Kelsen, Pure Theory of Law (Berkeley: University of California Press, 1978) at 217-18.

150 See Immanuel Kant, Immanuel Kant: Kritik Der Reinen Vernunft (Berlin: Akademie Verlag, 1998) at 332 ("I understand by the transcendental idealism of all appearances the doctrine that they are all together to be regarded as mere representations and not things in themselves, and accordingly that time and space are only sensible forms of our intuition, but not determinations given for themselves or conditions of objects as things in themselves. To this idealism is opposed transcendental realism, which regards space and time as something given in themselves (independent of our sensibility)."). 
themselves. Because ultimate reality - the thing-initself - is unknowable, that which is available to our sensory and cognitive capacity is already all that we can hope to know.

Kant argues that synthetic a priori judgments concerning the representations of space and time - are a necessary prerequisite for experience and rationality. ${ }^{151}$ But for their existence, cognition would not be. Furthermore, the categories are a sine qua non of the objects coming into being for us. Thus a cognitive unavoidability is the basis of human self-understanding and that which we could possibly assert about the concept of something being "true".

Kant's argument is not limited to epistemology; he also raises a connected ontological argument. Kant as-

\footnotetext{
151 See Immanuel Kant, Critique of Pure Reason, translated by Werner S Pluhar (Indianapolis, IN: Hackett, 1999) at 88 ("Therefore experience, as empirical synthesis, is in [regard to] its possibility the only kind of cognition that provides reality to all other synthesis. By the same token, this latter synthesis, as a priori cognition, has truth (agreement with the object) only because it contains nothing more than what is necessary for synthetic until of experiences such. Hence the supreme principle of all synthetic judgments is this: Every object is subject to the conditions necessary for synthetic unity of the manifold of intuition in a possible experience. Thus synthetic judgments are possible a priori if we refer the formal conditions of a priori intuition, the synthesis of imagination, and the necessary unity of this synthesis in a transcendental apperception to a possible experiential cognition as such, and if we then say that the conditions for the possibility of experience as such are simultaneously conditions for the possibility of objects of experience and hence have objective validity in a synthetic a priori judgment.").
} 
serts that our capacity for reason, by virtue of which we are capable of having a free will, also gives us a form of selfhood that is a threshold category for humanity

For Kant, the quality of a good person is dependent on the overlap between one's free will and one's reason in the reproduction of moral conventions. Only those decisions that mirror our profound duties, independent of our inclinations, and to an extent independent of outcomes, meet this test. ${ }^{152}$ At the base of morality and society are threshold levels of rationality that permit free will.

Kant's categorical imperative asserts a baseline universal rule that overlaps with our cognitive capacities. ${ }^{153}$ The key aspect of this is the concept of freedom of choice; that once autonomy and freedom have defined one's choices, one is self-governing. This form of autonomous rule formation means that both the process and outcome engender an identifiable form of cognitive and subjective reproducibility, an economy

152 For the teleological vs. deontological debate surrounding Kant see generally, R M Hare, "Could Kant Have Been A Utilitarian?" (1993) 5:01 Utilitas 1; David Cummiskey, Kantian Consequentialism (New York: Oxford University Press, 1996).

153 "I ought never to act except in such a way that I could also will that my maxim should become a universal law". This is only one articulation of the categorical imperative, for a fuller list see Roger J Sullivan, Immanuel Kant's Moral Theory (Cambridge, UK: Cambridge University Press, 1989) at 346. 
of affirmation.

Kantian reason is immanent and thus requires no contextualized normative formation. It demands only that the individual choose to exercise it. At the same time, however, the individual's moral judgment and true motivation according to the free exercise of reason are to be sharply distinguished from abiding by the law - itself an ethical obligation.

Insofar as each can distinguish and defer to the law, and there is no categorical imperative requiring conscientious objection to it, positive law binds. Jeremy Waldron has argued that in this sense, Kant is a legal positivist. ${ }^{154}$

While Kelsen does not assert the same kind of transcendental a priori norm as Kant, the Grundnorm can be seen as performing a role similar to Kant's thing-in-itself. The Grundnorm is the paradigmatic category upon which the legal order is founded. The Grundnorm is not knowable; its existence is a counterfactual assertion from which an understanding of the

\footnotetext{
154 See J Waldron, "Kant's Legal Positivism" (1996) 109:7 Harv L Rev 1535 at 1566 ("If, nevertheless, there are reasons for thinking that society needs just one view on some particular matter to which all its members are to defer, then there has got to be a way of identifying a community view and grounds for one's allegiance to it that are not predicated on any judgment one would have to make concerning the view's moral rectitude.") .
} 
legal would otherwise be impossible. The thing-initself and the Grundnorm are posited as necessary conceptualizations for the coming into being of a subjectivity that manifests itself in a socio-cognitive and legal order enabled through autopoiesis, upon which the legal subject depends. ${ }^{155}$

However, Kelsen and subsequent legal positivists do not take on the deeply critical dimension of Kant's thing-in-itself, which invalidates any claim that phenomena can be conclusively defined, and makes this fact the constant corrective to the inadequacy of our capacities. The thing-in-itself can thus give rise to the necessity for continuous resourcing of Erkenntnis ${ }^{156}$, with no affirmative end in sight. ${ }^{157}$

155 This kind of counterfactual normative unavoidability is comparable to Habermas' late Kantian ideal speech situation. See Habermas, supra note 20 .

156 Erkenntnis is not easily translatable. It is often rendered as "knowledge" but it also carries the meaning of awareness, insight or perception. It might therefore be rendered as "knowledge recognition".

157 Duncan Kennedy concludes his paper on the Kelsen/Hart debate by noting that the CLS project is about this very distinction: "That results are not determinate in some cases, according to Bix, does not 'negate the [...] possibility of right answers even for the harder cases.' The only intelligible meaning of a 'right answer' in a case, hard or easy, given the phenomenology above, is that having worked with the time and resources available and according to a chosen strategy, the interpreter can't find an alternative to some particular apprehension of what rule applies and what it requires when applied. In other words, after performing the phenomenological reduction, the 'right answer' is the one that is produced by an argument having the 'effect of necessity.' As to whether there is a right answer in the sense of one available to cognition, CLS takes the position of Kant as to the 'thing in itself.'" See "Left Phenomenological Alternative To The Hart/Kelsen 
Kant's lasting ethical insight extends beyond the admonition towards rational self-governance. As we will see in Chapter four when we come to Adorno, the unknowability of the thing-in-itself requires ongoing re-calibration of our ability to have knowledge or assert truths.

The right-Kantian position, adopted by Kelsen, takes this to mean that the unknowability of the object allows, if not mandates, the reduction of the object to the bare understanding of its possible a priori affirmation. We can only understand how and what we posit, not anything about what we posit.

A left-Kantian position, adopted by Adorno, would take such an a priori understanding to be the trace of self-awareness, but for which we could admittedly not know enough to be epistemically legitimate, yet would assert that this does not exhaust our debt to the object.

A full understanding of the Kantian turn does not license us to take the fact or understanding of selfpositing as an adequate ethical or moral threshold. Rather, we are encumbered both by the limitations of

Theory of Legal Interpretation" in Duncan Kennedy, Legal Reasoning: Collected Essays (Aurora, Colo: Davies Group Publishers, $2008)$. 
our own cognition, as well as by the truth (and justice) claims attendant upon the object.

Any unravelling of this double challenge to truth and justice claims comes at the expense of epistemic legitimacy. Adorno calls for the priority of the object in an epistemic process driven by the justice claim of subjectivity. Only subjectivity can render justice to the object's alterity, because only consciousness renders justice willable or known.

Brian Leiter in his late-positivist account explicitly affirms the existence of a schism between the process of knowing and the object of knowledge:

Let us distinguish between epistemic values and moral values. Epistemic values specify (what we hope are) the truth-conducive desiderata we aspire to in theory construction and theory choice: evidentiary adequacy ("saving the phenomena"), simplicity, minimum mutilation of well-established theoretical frameworks and methods (methodological conservatism), explanatory consilience, and so forth. Honor those values-even the explicitly pragmatic ones like simplicity-and, we hope, we will acquire knowledge. Moral values are those values that bear on the questions of practical reasonableness, e.g., questions about how one ought to live, what one's obligations are to others, what kind of political institutions one ought to support and obey, and so forth. [...] The question, then, is whether the judgments of "significance" and "importance" that [...] are indispensable in theory-construction must make reference to moral values in addition to epistemic values? Descriptive jurisprudence accepts the Banal Truth in answering this question "no". Descriptive jurisprudence says that epistemic norms, alone, suffice 
to demarcate legal phenomena for purposes of jurisprudential inquiry. ${ }^{158}$

Leiter's characteristically right-Kantian reading reproduces a thread from Bentham through Kelsen: the positing of subjectivity as a legitimate and exclusive normative source.

However, if the transcendental subject is strictly supposed to require sensation and nothing else in order to function and thus to judge accurately (so as to describe legal norms), then it would be attached not only to pure apperception, but just as much to its source of perception, from which its matter flows.

But this undermines the doctrine of subjective constitution, which according to Kant, entails that matter cannot be traced back to the source of itself. For Kant, the idea of something immutable, identical to itself, collapses. That idea is derived from the domination of the concept, which by aspiring to be constant towards its content, precisely its "matter", is in fact for that reason blind to its matter and non-identical with it.

Kelsen's (and Leiter's) one-sided affirmation of an unavoidability of conceptualization imposes epis-

158 B Leiter, "Beyond the Hart/Dworkin Debate: The Methodology Problem in Jurisprudence" (2003) 48 Am J Juris 17 at 34-5. 
temic limitations under the guise of being able to differentiate binding norms. However, it in fact reduces the capacity for antinomical negotiation by restricting itself to what Leiter himself calls the "banal truth" of description. In chapter four, the justice repercussions of this epistemic limitation will be juxtaposed with the conception of other-regarding drawn from Adorno's analysis of the same concepts.

\section{Hart's Concept of Law}

In the Concept of Law, H.L.A. Hart moves beyond the tautology of Kelsen's Grundnorm, qua empirical a priori, embracing a closed but more emancipatory form of methodological positivism. Hart argues that what Kelsen understood to be an a priori norm is predicated on a metanorm, a rule that factually determines under what circumstances other more concrete rules will be observed or enforced.

The "rule of recognition" has no constitutive function other than the fact of being necessarily reproduced. It, like Kelsen's Grundnorm, is an a priori moment. The important distinction is that the being of law is asserted inductively. No need to impose a counter-factual Grundnorm. Instead, Hart sets out to prove 
the inevitable recurrence of deep patterns of legal construction. These patterns or rule construction, stripped of the transitory, would finally allow us to distinguish law from other forms of normative ordering. Whatever law could become, it would always have to contain this core.

Hart writes, "[t]he rule of recognition exists only as a complex, but normally concordant, practice of the courts, officials, and private persons in identifying the law by reference to certain criteria. Its existence is a matter of fact."159 Thus, like Kelsen, Hart adopts a post-imperativist position that does not ground law in the affirmations of sovereign power:

The rule of recognition providing the criteria by which the validity of other rules of the system is assessed is in an important sense, [...] an ultimate rule: and where, as is usual, there are several criteria ranked in order of relative subordination and primacy one of them is supreme. These ideas of the ultimacy of the rule of recognition and the supremacy of one of its criteria merit some attention. It is important to disentangle them from the theory, which we have rejected, that somewhere in every legal system, even though it lurks behind legal forms, there must be a sovereign legislative power which is legally unlimited. ${ }^{160}$

In contradistinction to Kelsen, Hart models the means by which law, independent of its facticity, is rei-

159 HLA Hart, The Concept of Law, 2d ed (New York: Oxford University Press, USA, 1997) at 110 .

160 Ibid at 105-106. 
fied. Hart defends a positivistic conception of the ontological status of the law. ${ }^{161}$

Thus, the only necessary claim is that the law is always posited relying on an identifiable second order action. Primary rules "impose duties"162 while secondary rules "specify the ways in which the primary rules may be conclusively ascertained, introduced, eliminated, varied, and the fact of their violation conclusively determined."163 As Owen Cox argues:

The purpose of the secondary rules is to remedy the defects of uncertainty, staticity and inefficiency which are found in a system consisting only of primary rules. [...] It is the rule of recognition which has precedence, as it is the rule which enables laws of the system to be identified and applied, and thereby to be distinguished from other kinds of rules. ${ }^{164}$

The secondary rules are the means by which "the contrast between legal and other rules hardens into some-

161 See, Leo Zaibert \& Barry Smith, "Legal Ontology and the Problem of Normativity" (1999) The Analytic-Continental Divide, Conference, University of Tel Aviv.

162 Supra note 159 at 81 .

163 Metalegal knowledge is legal knowledge about legal knowledge, or, legal knowledge that refers to other legal knowledge. This category of legal knowledge is roughly equivalent to Hart's secondary rules; it includes norms that refer to primary norms. Two basic functions are supported by metalegal knowledge. First, it regulates the dynamics of the legal system, for instance, by prescribing how to make amendments, and how to issue new primary norms). Second, it provides mechanisms to solve conflicts between instances of legal knowledge.

164 Owen Cox, "The Meaning of Law in the Concept of Law" (1999) 24 Austl J Leg Phil 145 at 147. By "staticity" Hart means the static, unchanging quality of rules if there is no secondary rule, see Hart, supra note 159 at 92-94. See also, Robert S Summers, "Professor HLA Hart's 'Concept of Law'" (1963) 1963:4 Duke LJ 629 at 639-40. 
thing definite". ${ }^{165}$ The law reproduced through the rule of recognition is prima facie one that participants would recognize as such.

His version of positivism asserts that laws do not necessarily reproduce or satisfy demands of morality, despite having "often done so". ${ }^{166}$ Dilution of the ability to identify normative claims is for Hart at risk when we disregard the necessary separation between law and morality. In fact, Hart argues against claims that immoral laws are not law:

If [...] we formulate our objection as an assertion that these evil things are not law, here is an assertion which many people do not believe, and if they are disposed to consider it at all, it would seem to raise a whole host of philosophical issues before it can be accepted [...]. [W] hen we have the ample resources of plain speech we must not present the moral criticism of institutions as propositions of a disputable philosophy. ${ }^{167}$

For Hart, general acceptance of a "plain speech" notion of law is the only way to promote the emancipatory justice potential of law as against the anomic inclinations of sundry subjectivity.

Hart seeks to model the law with comparable objectivity to that of natural phenomena and the inductive

165 Hart, supra note 159 at 92-98.

166 Ibid. at 185-86.

167 HLA Hart, "Positivism and the Separation of Law and Morals" (1957) 71 Harv L Rev 593 at 602 . 
method. ${ }^{168}$ His key affirmation, beyond the separation of law and morality, is that the law is identifiable by inductive generalization. The recurring characteristics of the law as we reproduce it are taken to be essential. The fact of the secondary rule is sufficient in itself to ground the existence of the law. As Hart puts it, quite categorically:

The statement that a rule exists may now no longer be what it was in the simple case of customary rules - an external statement of the fact that a certain mode of behaviour was generally accepted as a standard in practice. It may now be an internal statement applying an accepted but unstated rule of recognition and meaning (roughly) no more than "valid given the system's criteria of validity". In this respect, however, as in others a rule of recognition is unlike other rules of the system. The assertion that it exists can only be an external statement of fact. [author emphasis] ${ }^{169}$

Hart, together with other legal positivists, argue that this reduction is both openly imposed by social practice and a necessary prerequisite for exploring the law.

"Exploring" and "defining" the law in this way gives us the Law that we would otherwise not be able to distinguish. However, the desire to attribute to the law the status of an is, a status of being, inevi-

168 Posner discounts Weber's theory of law on the basis that Weber does not produce scientifically valid "conditional predictions". Richard A Posner, "The Sociology of the Sociology of Law: A View from Economics" (1995) 2:4 Eur JL \& Econ 265 at 265. 169 Hart, supra note 159 at 110 . 
tably necessitates a theory according to which knowledge of the law can legitimately generate its being .

It appears superficially impartial to define law as "being" through its reproduced manifestations. An example of this is the gapless web theory of the private law disclosed in Weber's postulates of legal formalism:

(1) that every decision of a concrete case consists in the "application" of an abstract rule of law to a concrete fact situation;

(2) that by means of legal logic the abstract rules of the positive law can be made to yield the decision for every concrete fact situation;

(3) that consequently, the positive law constitutes a "gapless" system of rules, which are at least latently contained in it, or that the law is at least to be treated for purposes of legal practice as if it were such a gapless system;

(4) that every instance of social conduct can and must be conceived as constituting either obedience to, or violation, or application, of rules of law. ${ }^{170}$

And yet the existence, or being of the law, in contrast to its manifestations, is a category inaccessible to inductive investigation. ${ }^{171}$

170 Weber, supra note 143 at 102 .

171 Stephen Perry makes a parallel point: "[The] descriptiveexplanatory approach is appropriate if one intends to do science, but for jurisprudence, which is a branch of philosophy, the most appropriate procedure is conceptual analysis. When jurisprudence is understood in this way, and gives up trying to borrow inappropriate elements from the descriptive-explanatory approach, it can be seen that particular theories of law must be offered from the point of view and must be defended, in part, by resort to moral 
Neither the mere reproducibility of the law, nor the conceptual elision supported by epistemic causality can legitimately or reliably speak to what law is. Even if one were able to produce categories capturing all the attributes of every law that has ever come into being, one would not be entitled to affirm the existence of law on the basis of those categories.

It is one thing to have a (relatively) consistent practice that allows judges to determine (to interpret, to prescribe) what "is" the law applicable to a particular problem. On this basis we may be able to say, for example, that for there to "be" a contract there must "be" offer and acceptance. By this we would mean to state a proposition characterizing a certain set of practices, and inevitably beg questions as to nested sets of practices (around how offer and acceptance are identified, for example). It is quite another thing to assert that the law of contracts therefore "is" a being distinct from the fluid subjectivities and practices that fashion it.

To the extent that the nature of the law itself is plastic and able to transform or be transformed, we are obligated to see existing laws both substantively

argument. The result is the complete abandonment of methodological positivism." See Perry, supra note 108 at 513. 
and formally as contingent iterations. In other words, we are barred at looking at the law as we know it and deriving causal or deterministic conclusions from it.

The legal positivist position in fact achieves the opposite of making our understanding of the law more neutral. By focusing on the epistemic equivalent of Bentham's utilitarian principle - through a definition of the law that seeks the least resistance to adoption because it corresponds to prima facie expectations of the greatest number of people - legal positivism undermines the capacity of law to embrace alterity. In doing so, the law is deprived of a necessary prerequisite for its evolution, and thus of its neutrality with respect to future possible law.

The argument being made here is not that the synthetic theory of late legal positivism asserts a closed canon. Rather, its methodology is based on the valuation of affirmations that are incommensurable with an adequately differentiated understanding of the law and its relation to epistemology. Because these deficiencies are not apparent without a metatheoretical analysis, there is no argument that can be made against legal positivism on its own terms.

Compare the inductive statements derived in New- 
tonian physics. ${ }^{172}$ Newton's law of universal gravitation does not purport to derive the category of being of gravity from the observation of the attraction between two bodies. It does not provide a "rule of recognition" of gravity. To the extent that the context of physical laws and conditions remains constant, gravitation can be predictably assumed to manifest even in the absence of observations, or even if no one ever existed. The nature of its being is not dependent on us and does not derive from its recognition. The law is something that is produced. It is nothing that would exist without us. Thus there is a contradiction in Hart's legal positivism ab initio on at least two fundamental levels.

Firstly, the attempt to derive the existence of the law from access to its contingent manifestations (since the law is not simply a given) always entails mapping the law onto the epistemological (and hegemonic) constraints of that very methodology. Newton's universal gravitation theory does not purport to

172 See Sir Isaac Newton \& Florian Cajori, Sir Isaac Newton's Mathematical Principles of Natural Philosophy and His System of the World: The system of the world (Berkeley: University of California Press, 1962) at 547 ("In [experimental] philosophy particular propositions are inferred from the phenomena and afterwards rendered general by induction".). I do not purport here to canvass post-Newtonian physics, which in any event would provide little comfort for Hart's position on the being of law. 
ground the nature of the phenomenon to which it applies. Rather, it makes the prior existing phenomenon of gravity accessible and predictable for us. In contrast, the being of law advanced by Hart and other legal positivists expresses itself through the particular theoretical narrative deployed.

Secondly, the being of law is indivisible from human will. To affirm a being for law is ideological, in that its counterfactual positing requires the eclipse of the conceptual and factual inadequacy of the category of law's being. $^{173}$ The sleight of hand here is that positivism makes the indisputable assertion that the social practice of interpreting and applying norms involves positing those norms. However, positivism then conflates this set of social facts with a greater claim, namely that the law is identifiable independent of the will of actors.

173 One irony of legal positivism is that its quest for legal science is at odds with the notion of science described by Aristotle when he defines what justice based on $\Phi$ ú $\sigma$ means. Kenny notes, summarizing Aristotle's position, "[...] things that are capable of being other than they are, are excluded as subjects of scientific knowledge. Only the necessary can be a subject of scientific knowledge. Necessity is limited to things that cannot be otherwise, or, from another point of view, it is limited to things whose basis and essence are not capable of being otherwise." See Aristotle, The Eudemian Ethics, translated by Anthony Kenny (Oxford: Oxford University Press, 2011) at 65. Shellens maintains that "[n]atural law is not present (a) where the answer to a problem depends upon our free moral decision and, hence, cannot be supplied by scientific proof; and (b) where no rule of a general character is involved." see shellens, supra note 97 at 87. 
The existence of a fact (here that law is posited) is not the proof that either the posited or the act of positing is anything in and for itself. The is here does not suffice to ground an independent claim or nexus for its self-referencing, but rather reflects the iteration (and the ambivalence) of the will on which it depends.

The being of this will itself cannot be fit into an inductively reasoned causality either. The being of this will is a constellational articulation, adequate or not, to the challenge of selfhood and the reproduction of a collective. John Finnis writes:

A theorist, [...] cannot give a theoretical description and analysis of social facts [including law] unless he also participates in the work of evaluation, of understanding what is really good for human persons, and what is really required by "practical reasonableness," that is, reasoning about what one ought to do. He cannot do this because "the subject-matter" of the theorist's description [namely, law] does not come neatly demarcated from other features of social life and practice. ${ }^{174}$

Law's positing depends on and refracts constellational justice considerations that only become visible when subjected to a metatheoretical analysis that explicitly includes the epistemic nexus of justice claims.

Thus being, not of the law itself, which I have undertaken to show is a tautological concept, but ra-

174 Finnis, supra note 19 at 4. 
ther of that which the law is a positing of, independent of the discrete articulation, becomes a central moment in both the unravelling of legal positivism and a bridge to understanding the role of justice constellations and a justice matrix.

Hart's legal positivism is systemically disabled from producing a vision of the law adequate to an emancipatory outcome. As explored, it may provisionalIy act as a threshold for the evolution of the legal, but it invariably carries with it the weight of its own hypostasis. The very terms that Hart is trying to remove from the debate by the production of an analytic core achieve the contrary result.

As in the case with Bentham and Kelsen, the conceptualization of the law stops here at its selfimposed epistemic limits, while at the same time claiming the necessity to do so. The underlying deficit of these methodologies is the unwillingness to embrace the critical interdependence of the epistemic frame and the normativity it generates. That is, even if the most plausible positivist argument is made, such plausibility is neither epistemically nor normatively neutral. This way of thinking is one key source of failure of the law when confronted with macro- 
normative challenges.

This brief examination of legal positivism exposes epistemic limits and related justice deficits as regards emancipatory claims. Such failure is however not limited to the legal positivist episteme. Its other, natural law, also proceeds on the basis of emancipatory claims, even asserting justice alterity as one of its central axes. And yet, natural law also reproduces epistemic categories that are disabled from actualizing an emancipatory justice alterity.

\title{
Natural Law
}

\author{
Conceptualizations of natural law ${ }^{175}$ emphasize jus- \\ tice claims beyond the immanence of conventional \\ claims. ${ }^{176}$ Whether the source is located in a theologi-
}

175 Shellens points out that the term natural law is inherently problematic" "As for the terminology in general, it cannot be denied that the term $\delta$ lkalov $\varphi v \sigma l k o v$ is more satisfactory than the more equivocal expression 'natural law'. We make a clear statement when we say: 'of justice part is natural, part is legal.' Such a statement cannot easily be misunderstood; it declares that the second part, namely, legal justice, is man-made justice. Conversely, it makes natural justice an eternally open question, unsolved and maybe unsolvable. Because of the close affinity of 'legal' and 'law', the term 'natural law' is more likely to be confounded with man-made law than the term 'natural justice'. Also, at times it might be safer to approach the whole problem of natural law in terms of whether a certain conduct accords with natural justice. However, since the term 'natural law' is commonly used, we shall follow the established tradition and speak, though with some hesitation, about natural law and legal law." See Shellens, supra note 97 at 73 [footnotes omitted].

176 See Paul Vinogradoff, "Legal Standards and Ideals" (1924) 23:1 Mich L Rev 1 at 5 ("Let us notice that the expression 'Law of $\mathrm{Na}$ - 
cal element, a state of nature to be discovered, or the Stoic conception of natural law deriving from human reason, natural law depends on the intervention of an otherness. ${ }^{177}$

Whereas we are called upon within legal positivist narratives to affirm conceptual restrictions, natural law intervenes against such identification. Max Salomon Shellens, in his analysis of the contradictory assertions of natural law in Aristotle, summarizes as follows: "natural law serves better the task of justice as a whole; it is capable of answering questions that are unavoidable in our social life, but are beture' was used at that time for two different purposes. It appears commonly as the theoretical foundation as the axiomatic truths from which a rational system of positive law could be derived. Pufendorf's Treatise may serve as an example of such an attempt to deduce the precepts of actual law from certain abstract propositions. This is connected, of course, with the rationalistic tenet that all knowledge is to be derived from a few self-evident axioms; hence, the existing legal rules have to be accepted as manifestations of permanent juridical principles. But the law of nature could also be used, and was actually used as a critical standard for distinguishing between reasonable and unreasonable rules. The law of nature in this sense was to act as an acid test of positive law. In this sense, as a standard of right law, it was developed, e.g. by Rousseau and by Kant, and it formed the philosophical element of a revolutionary movement."). 177 See Sir Frederick Pollock, Jurisprudence and Legal Essays (New York: St. Martin's Press, 1978) at 124 ("The term 'Law of Nature', or natural law, has been in use in various applications ever since the time of the later Roman Republic. Their variety and apparent diversity have tended to obscure the central idea which underlies them all, that of an ultimate principle of fitness with regard to the nature of man as a rational and social being, which is, or ought to be, the justification of every form of positive law. Such a principle, under the name of reason, reasonableness, or sometimes natural justice, is fully recognized in our own [English] system, but the difference in terminology has tended to conceal the real similarity from English lawyers during the last century or more."). 
yond the capacity of justice if we adhere only to our public laws."178 Natural law affirms an alterity that contains an emancipatory dimension, i.e. the claim to overcome subjectivity in its own name. This is its key threshold moment, its emancipatory unavoidability. Natural Law counterbalances proximate, and conventional justice claims. ${ }^{179}$

Natural law represents a transcendent pole of justice alterity. This transcendence comes at a price. The transcendence of natural law depends on the contradictory ability both to universalize claims and to discount emancipatory, heterogeneous, or antinomical justice claims. The self-overcoming of natural law carries with it the risk of alienation from both process and outcome. Natural law categories confine the justice imaginary to being squarely within an economy of affirmation that has as its goal its own reproduction. ${ }^{180}$

\footnotetext{
178 Shellens, supra note 97 at 99.

179 This is particularly the case when the two overlap, i.e., when both the "legal" right to a remedy, and a high degree of subjective identification is present. It is for this reason that natural law is also a significant contributory to human rights law. 180 Hobbes" definition is that "[t]his is that law of the gospel: Whatsoever you require that others should do to you, that do ye to them. And that law of all men, quod tibi fieri non vis, alteri ne feceris." See Thomas Hobbes, Leviathan, Parts I and II (Calgary: Broadview Press, 2010) at 127. This universalization reifies the limits of an explicitly known economy of affirmation. The al-
} 
In order to make out this claim, I will focus on two representative natural law theories, namely those of John Finnis and Robert Alexy. My goal is to identify overarching contradictions in the construction of the theory.

Whereas Finnis continues to serve as a touchstone for modern natural law theory, Alexy uses metatheory to anchor natural law in an immanent critique of the justice conceptions raised by positive law. ${ }^{181}$ Both assert the necessity of placing the existence of law in a normative context that derives its legitimacy outside of the "legal". Each views positivism as an untenable conceit.

Through my analysis of Finnis, I will undertake to show how some of the fundamental tenets of natural law are susceptible to an equally disabling justicetheoretical outcome. Alexy consciously uses metatheory to avoid the normative/epistemic contradictions that

terity of justice cannot be adequately represented from this perspective.

181 James Gordley, writes in the "The Moral Foundations of Private Law", (2002) 47 Am J of Jurisprudence 1 at 22 that "[t]here is, then, a life to be lived which is truly of value, and an ability to see what that life entails, although we can be mistaken." Gordley distinguishes between well-being and happiness, with the emphasis on overarching legitimacy of the former. The refutation of various forms of limited rationality, particularly that of economic efficiency, rests on a natural law revival. This seemingly plausible embrace of justice alterity suffers from the same limitations that will be explored in Finnis. Pointing to an otherness whose ostensible purpose is to lead us back to ourselves, is a tautology that enthrones a self and may be its undoing. 
Finnis's approach engenders. However, Alexy's immanent critique is ultimately disabled from identifying the role of justice alterity or the scope of antinomical resourcing necessary to the task of macro-normative transformation.

\section{Finnis}

John Finnis's Natural Law and Natural Rights ${ }^{182}$ became a benchmark for contemporary natural law theory upon its release in 1980 and remains one of the central texts of the canon. ${ }^{183}$ Finnis approaches the ques-

182 Finnis, supra note 19.

183 Danielson's comment is apposite: "Natural Law and Natural Rights warrants comparison with John Rawls' A Theory of Justice [ (Cambridge, MA: Belknap Press of Harvard University Press, 1971)]. This is a large claim, as Rawls' book has become the definitive modern solution to the problem of justifying institutions. Finnis develops a classical alternative to this dominant approach. This is an alternative theory - not a mere critique comparable to Rawls' work in three crucial ways. First, NLNR is a treatise bringing together ethics, political philosophy, and jurisprudence under a unified theory. Contrast this with monographs restricted to a single field or presenting wide-ranging arguments not yet unified into a theory. Second, NLNR presents a previously undeveloped theory, not variations on the familiar themes of utility, contract, and rights. A measure of this is the extent to which natural law theory (like the social contract tradition before Rawls) is generally ridiculed and dismissed. Finnis goes about reintroducing natural law theory in a way similar to Rawls. NLNR is neither a history of its tradition nor a defence of the classics against their critics. Instead Finnis restates and elaborates natural law as a "theory of the rational foundations for moral judgement" (supra note 19 at 25). Finally, Finnis's solution to the foundations problem makes his theory relevant. After Rawls, those who rejected utilitarianism had to work within the Rawlsian framework or say why not. Some who have opted outNozick and Thomson are good examples - have done so under the banner of natural rights. But their arguments rely heavily on appeals to a background of natural laws, which they have not developed. Up to now, natural rights has been a moral theory that lacks foundations. Henceforth natural rights theorists must work within Finnis's framework or propose an alternative to it." See 
tion of justice as a eudaemonic essentialist. ${ }^{184} \mathrm{He}$ sets out the relation between law and moral others using a constellation of justice claims drawn from "knowledge, life, play, aesthetic experience, sociability, friendship, religion, and practical reasonableness."185 The constellational characteristic of these goods is expressed explicitly:

Each is fundamental. None is more fundamental than any of the others, for each can reasonably be focused upon, and each, when focused upon, claims a priority of value. Hence there is no objective priority of value amongst them. ${ }^{186}$

Each of these goods is

[a]n intrinsic good [...], considered to be desirable for its own sake and not merely as something sought after under some such description as "what will enable me to impress my audience" or "what will confirm my instinctive beliefs" or "what will contribute to my survival."187

Finnis thus locates his normative epistemology in what might be called a justice biotope, further adding somewhat to its diversity by including the following absolute human rights:

Peter Danielson, "Book Review: Natural Law and Natural Rights" (1980) 30:4 U of T LJ 441.

184 Whereas Bentham's position generalizes positive law precisely because of its lack of normative anchoring, Finnis's position attempts to overcome this limitation by asserting a eudaemonic natural law constellation. Human needs are no longer limited to subjective immediacy, but are the product of the intermediation of normative invariables. Finnis's eudaemonics takes a deontological turn.

185 Finnis, supra note 19 at 86-89.

186 Ibid at 93.

187 Ibid at 62 . 
[...] the right not to have one's life taken as a means to further an end, the right not to be lied to if truth should be reasonably expected, the right not to be condemned on knowingly false charges, the right to procreate, and the right to be consulted in any assessment of what the common good requires. ${ }^{188}$

Finnis asserts that these rights are intimately associated with human flourishing. ${ }^{189}$

Further, he asserts that the legitimation of such goods and rights is the innate result of human interiority. ${ }^{190}$ The moment we take up the process of understanding who we are, we are driven to embrace a form of critical interiority that forces us to seek our identity in the constellation of values which, taken together, produce our relationship to justice. Finnis writes: "by a simple act of noninferential understanding one grasps that the object of the inclinations (e.g. a desire for knowledge/truth) which one experiences is an instance of a general form of good, for oneself (and others like one)."191

Finnis differentiates participation in the emancipatory and open-ended search for knowledge and truth from the attempt to functionalize that search toward

Ibid at 225.

Ibid at 23.

Ibid at 32 .

Ibid at 34 . 
an instrumental outcome. ${ }^{192}$ The resulting theory of natural law,

(1) critiques and rejects ethical skepticism, dogmatism, and conventionalism; (2) clarifies the method of descriptive and explanatory social theories like political science, sociology, etc. [...]; and (3) critiques and rejects aggregate conceptions of the right and just, like utilitarianism and consequentialism. ${ }^{193}$

The paradigmatic element in Finnis's catalogue is that of practical reasonableness. ${ }^{194}$ In fact, Finnis's entire system is based on this metanormative, metaepistemic category

He describes practical reasonableness as that "which is participated in precisely by shaping one's participation in the other basic goods, by guiding one's commitments, one's selection of projects, and what one does in carrying them out."195 The justice claim connected to this is the pre-requisite for a natural theory's ability to

[...] undertake a critique of practical viewpoints, in order to distinguish the practically unreasonable from the practically reasonable, and thus to

192 Ibid at 64 .

193 John Finnis, "Natural Law Tradition" (1986) $36 \mathrm{~J}$ Legal Educ 492 .

194 Practical reasonableness is "[m]ore important (for ethics, political theory and jurisprudence) than the account of basic human goods is for the account of the second level of ethical reflection, identifying the 'requirements of practical reasonableness' or 'modes of responsibility.'" See ibid at 494, cited in Caryn L Beck-Dudley \& Edward J Conry, "Legal Reasoning and Practical Reasonableness" (1995) 33:1 American Business Law Journal 91 at 101. 195 Finnis, supra note 19 at 100. 
differentiate the really important from that which is unimportant. [...] A theory of natural law claims to be able to identify conditions and principles of practical right-mindedness, of good and proper order among men and in individual conduct. ${ }^{196}$

The goods taken together provide the orientation for practical reasoning: "they constitute either the explicit starting point of reasoning about what to do"197 or "the implicit, irreducible assumption of reasoning". ${ }^{198}$

Practical reasonableness ultimately is both a precondition for and the most elaborate iteration of a metajustice claim. Indeed, Finnis identifies it as such: "[t]he common good is identified as the condition that needs to exist for each individual to obtain his or her own objective."199 Caryn Beck-Dudley and Edward Conry summarize Finnis's criteria for determining when this condition has been met. A person participating in practical reasonableness:

(1) maintains a harmonious set of principles; (2) exhibits no partiality towards basic values (no arbitrary preferences); (3) exhibits no partiality among humans; (4) be (sic) detached; (5) shows fidelity towards basic values; (6) brings about good in the world; (7) observes the strict inviolability of basic human rights; (8) fosters the common good; and (9) follows

\footnotetext{
Ibid at 18

Ibid at 63 .

Ibid at 64 .

Ibid at 156 .
} 
one's conscience. ${ }^{200}$

Finnis, without speaking its name, thus introduces a fiduciary standard. The test of practical reasonableness is the constraint upon the potential legitimacy of all normative decisions. There must be no "personal gain," 201 and a prescriptive standard of care is required.

In a manner comparable to Adorno's postenlightenment project, Finnis is concerned with exposing the epistemic limits of a given set of normative judgments. He writes,

[a]ny judgment about what is an important feature of a legal system is, at least in part, a normative judgment. Ignoring this reality will systematically introduce a subtle, unstated, normative element. Bias may be more likely with positivism's inexplicit approach than in an approach that is openly normative. ${ }^{202}$

Here one observes Finnis playing off a metaepistemic justice claim - viz. a judgment concerning what counts as an important feature of a legal system - against a base level justice threshold (bias). This approach is comparable to the justice matrix approach discussed in the previous chapter.

It is certainly true that Finnis takes a signifi-

200 See Beck-Dudley \& Conry, supra note 194 at 102, citing Finnis, ibid at 100-127.

201 Beck-Dudley \& Conry, ibid.

202 Finnis, supra note 19 at 17. 
cant step towards realizing the goal of requiring "the decision maker to reveal the real reasons for making certain choices" and not "to hide behind rhetoric or legal fiction." 203

However, this first step does not open up the question as to a mode of critique that would force the "decision maker" to confront the inadequacies of the means of production of his own economy of affirmation or legacy subjectivity. Finnis's reliance on common sense is firmly contained within a narrowly circumscribed economy of affirmation. ${ }^{204}$ Finnis is incapable of modeling moments of radical transformation, and is also consequently blind to structural inadequacies in such moments as amongst each other. Additionally, Finnis's model relies on a static genetic model of human subjectivity. ${ }^{205}$ It sets up the

\footnotetext{
203 Beck-Dudley \& Conry, supra note 194 at 108 .

204 As evidenced in John Finnis, "Law, Morality and Sexual Orientation" in Human Rights and Common Good: Collected Essays (Oxford University Press, 2011). Here Finnis takes a position against same-sex marriage applying his understanding of practical reasonableness.

205 In this sense he plays on a concept of natural law that is immutable, but restricts this immutability by his concept of reasonableness. The assertion that the form of reasonableness could contain forms of justice alterity outside itself is tautological. Contrast this with Aristotle's paradigmatic natural law differen-

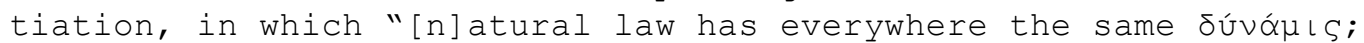
the mere human law could with equal propriety be different. Therefore, natural law is not capable of being different than it

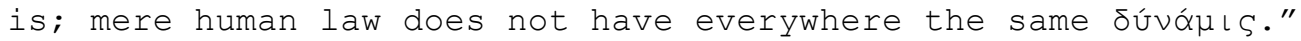
See Shellens, supra note 97 at 85. I question whether Finnis's catalogue of values exhaustively reflects this necessity for an
} 
idealized conditions under which a form of subjectivity could reproduce a current horizon of aggregate justice expectations. Successful implementation of his criteria "seeks to determine what the requirements of practical reasonableness really are, so as to afford a rational basis for the activities of legislators, judges, and citizens."206 Furthermore, he argues that "[t]he authority of the law depends [...] on its justice or at least its ability to secure justice."207 Neither the fallibility of rationality, nor the fallibility of legal justice is subject to a full epistemic critique. The justice claims contained within Finnis's basic goods can hold us back from the aggregate justice distortions of catastrophically deployed emancipatory claims, but they will also hold us back from overcoming catastrophic legacy subjectivity.

In this sense, Finnis reproduces the legal positivist fallacy of taking existing, posited conceptions of justice as the benchmark for normative accountability. The tethering of a proto-emancipatory epistemic claim to a normative matrix prevents the claim from

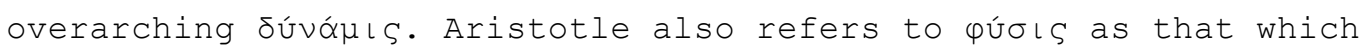
"prevails generally, that is, what is based on nature" (generally, and so by nature) is "what is valid in most cases and for the greatest length of time." see ibid at 93.

206 Finnis, supra note 19 at 290.

207 Ibid at 260. 
vitiating the basis of its own legitimacy, but it also truncates its emancipatory mandate.

There are two additional levels on which Finnis's theory displays limitations. First, the interrelationship between self and rationality that Finnis demands is symbiotic. A self moving beyond or outside her own rationality by definition would be illegitimate. An appeal to another to do the same would be equally untenable.

The relationship to rationality here is not only self-restricted, but also determines a threshold of legitimacy that imposes that restriction on our relationship to others. The strict connection made between justice and rationality is posited unquestionably. The justice externalities thus created are occluded as a pre-requisite for the experience of legitimate community. ${ }^{208}$

This leads to a second critique. Finnis's protofiduciary claim is inadequate because his concept of self would preclude any enabling of other that would be transformative of self or other to such a degree that the basic natural law values might be eclipsed.

Interventions that would deprive individuals of

208 See the discussion of legacy subjectivity in the previous chapter, supra at 47. 
the "freedom" to choose normative outcomes would be impossible. Thus, for example, a true prescriptive fiduciary model is inaccessible to Finnis's theory, since a fiduciary might undertake normative judgments for another, and is also unavailable to a critique of self with the same outcome.

Finnis's natural rights model resembles the Triceratops dinosaurs that Adorno describes as

drag[ging] their protective armor with them, an ingrown prison which they seem - anthropomorphically, at least - to be trying vainly to shed. The imprisonment in their survival mechanism may explain the special ferocity of rhinoceroses as well as the unacknowledged and therefore more dreadful ferocity of homo sapiens. The subjective moment is framed, as it were, in the objective one. As a limitation imposed on the subject, it is objective itself. 209

Finnis's vision of natural law may serve as a corrective to an imbalanced justice aggregate, particularly one that has been deprived of its constellational characteristics.

Yet the lack of metatheoretical differentiation leads to an outcome in which Finnis's justice conceptualization is unable either to impact on the process of producing an emancipatory justice alterity or to relate to the antinomical burdens attendant upon that

209 Adorno, supra note 1 at 180. 
process.

The disappointment $t^{0 / 1}$ problematic is not renderable from Finnis's frame of reference. Despite being aware of the antinomical nature of justice, the epistemic horizon that Finnis affirms does not permit an adequate modeling of justice externalities.

\section{Alexy: Argument from Injustice}

In contrast to Finnis's approach to natural law, Robert Alexy proceeds not by affirming (legacy) normative thresholds, but rather by looking at how positive law engages in performative contradictions.

In the Argument from Injustice, ${ }^{210}$ Alexy analyses an array of legal positivist standpoints. His intent is to distinguish definitive legal positivist features independent of semantic variation. The key question for Alexy is whether legal positivism produces systematically unaccounted for justice externalities. ${ }^{211}$ This form of immanent critique exposes the justice deficits of legal positivism, but reproduces concepts that limit the capacity of natural law to respond to its own antinomical inadequacy .

210 Alexy, supra note 55.

211 Alexy cites other examples of comparable approaches: the arguments from tyranny, lex corrupta, perversion of the law, and from totalitarianism. See ibid at 28 . 
Alexy identifies three distinguishing elements in legal positivism: authoritative issuance, ${ }^{212}$ social efficacy, and correctness. ${ }^{213}$ Natural law discounts authoritative issuance and social efficacy, whereas positive law disregards correctness. We have seen that post-imperativist legal positivists like Kelsen and Hart also discount arguments rooted in issuance, so I will not here examine Alexy's treatment of the same subject. Rather, I will focus especially on Alexy's analysis of social efficacy

Positivist arguments based on efficacy or effectiveness can be broken down into (i) an external (sociological) perspective and (ii) an internal (realist) approach. External, observable positivist narratives focus on compliance or sanction. Weber's definition illustrates this: "[a] system is to be called [...] law if it is externally guaranteed by the possibility of (physical or psychic) coercion through action aimed at

212 Having dealt with this in previous sections, I will reference this point here through the work of John Austin. Austin's theory placed the origin of law in a command backed up by a sanction. "Of the laws or rules set by men to men, some are established by political superiors, sovereign and subject: by persons exercising supreme and subordinate government, in independent nations, or independent political societies. [...] To the aggregate of the rules thus established, or to some aggregate forming a portion of that aggregate, the term law, as used simply and strictly, is exclusively applied. Thus the source of law is the sovereign who owes no deference and whose authority is conventionally affirmed. See John Austin, Lectures on Jurisprudence (London: J. Murray, 1873) at 89 .

213 Alexy, supra note 55. 
enforcing compliance or punishing violation, the action of a staff of persons expressly geared to this task. "214

Even applying Gustav Radbruch's threshold between legitimate and "lawless law",215 one could conclude that an enforced unjust statute should be considered valid law. Hoerster claims that there is significance to a "value-neutral designation for authoritatively issued and socially efficacious norms."216 From an outside observer's perspective, there is no absolute bar against the recognition of law independent of morality

Alexy asserts that the assessment of positive law becomes radically different when we adopt an internal, realist perspective. According to Alexy, for participants within a legal system, "legal decisions as well as legal systems as a whole necessarily lay claim to correctness."217 A law that contradicted this would be

\footnotetext{
214 Weber, supra note 106 [emphasis added].

215 See Gustav Radbruch, "Statutory Lawlessness and Supra-Statutory Law (1946)" (2006) 26:1 Oxford J Legal Studies 1 at 3 ("The conflict between justice and legal certainty may well be resolved in this way: The positive law, secured by legislation and power, takes precedence even when its content is unjust and inexpedient, unless the conflict between statute and justice reaches such an intolerable degree that the statute, as 'lawless law', must yield to justice.") .

216 Norbert Hoerster, "Die rechtsphilosophische Lehre vom Rechtsbegriff" (1987) JuS 181 at 187.

217 Alexy, supra note 55 at 36 .
} 
a performative contradiction.

A judge issuing a verdict cannot but raise the claim to have interpreted the law as it should be. ${ }^{218}$ Alexy writes, "[p]articipants in a legal system necessarily, on all sorts of levels, lay claim to correctness. If and in so far as this claim has moral implications, a conceptually necessary connection between law and morality is demonstrated." 219 This means that the law raises the claim of validity and as such, includes "the institutional context of lawmaking, law application, and law enforcement, a context that can be of significance on the question of a conceptually necessary connection between law and morality."220 A judge must view each distinct legal norm as "the point of departure for a norm-applying procedure in which he participates and whose result is accompanied by the claim to correctness."221 A judge cannot act in the absence of concern for the quality of the outcome and still appear to be pronouncing on the law.

Alexy's insistence that from an internal point of

218 According to Luhmann, "[w] e can [...] define law as the structure of a social system, a structure based on the congruent generalization of normative expectations of behavior." See Niklas Luhmann, A Sociological Theory of Law, translated by Martin Albrow \& Elizabeth King (London: Routledge \& Kegan Paul, 1985) at 82 .

219 Alexy, supra note 55 at 39.

220 Ibid at 24.

221 Ibid at 42. 
view law depends upon an effort to find correct moral outcomes is not unique to him. Lon Fuller had notably argued that law depends upon eight principles of internal morality, including stability, clarity, consistency, transparency in promulgation, and nonretroactivity. ${ }^{22}$ Fuller further asserted that if norms failing to respect these principles were made or enforced, by whatever method, they could not be "legal" in the narrow sense of being recognizable as law. ${ }^{223}$

In focusing on the immanent inadequacy of legal positivism, Alexy reproduces Finnis's reliance on a principled conception of the legal to overcome law's own structural limitations. However, justice claims against the law cannot be confined by overarching or parallel claims from within the law. Alexy's Argument from Injustice is disabled from recognizing this distinction. He correctly identifies the locus of legal positivism's wilful blindness, but cannot account for the fact that epistemically, this blindness is coeval with that of law's economy of affirmation - namely,

222 Lon L Fuller, The Morality of Law (New Haven: Yale University Press, 1969) at 46-62.

223 Höfe makes the legality of a system dependent on material aggregate thresholds that generalize justice goods for the collective, i.e., security, freedom of threat of physical violence or harm. See generally, otfried Höffe, Politische Gerechtigkeit: Grundlegung einer kritischen Philosophie von Recht und Staat, 4th ed (Frankfurt am Main: Suhrkamp Verlag, 1989). 
the very investments we have made in delimiting what can be socially affirmed and reproduced. ${ }^{224}$

The immutable opposition to injustice, from which Alexy's natural law theory defines itself, is substituted for the threshold moment of legal positivism's asserted legitimacy. Yet, whereas legal positivism collapses law with its economy of affirmation, thus depriving us of adequate resources to address emancipatory claims, Alexy collapses law with its emancipatory justice alterity, thus depriving us of adequate resources to address incommensurable legacy claims. In this sense, by discounting or not recognizing the justice claims around the normative power of the legal economy of affirmation, Alexy's response involuntarily follows positivism's reductionist path.

Despite taking the significant step towards grounding his argument in a metatheoretical justice critique, viz. one that does not advance an affirmative understanding of a set of justice claims, Alexy misconstrues positivism as an argumentative position, and not as a parallel response to potential justice externalities. In doing so, Alexy perpetuates the irreconcilability of the discourses surrounding positiv-

224 See Chapter 1, above, "Economy of Affirmation". 
ism and natural law and reproduces the need for their constant reiteration.

The inadequacy of Alexy's metatheoretical approach becomes clear in his analysis of "monstrous law," that is, law that intends or accepts manifestly immoral or unethical (meta)normative outcomes. A characteristic legal positivist response is that monstrous law is a liminal, exceptional case that should not affect law's general recognition. As a practical matter, Hart adds that because of its lack of normative sustainability, monstrous law will implode under the weight of its own inadequacy. The allocation of resources to the prospect that each law might be monstrous would be parasitic on the capacity to oppose injustices in other ways. ${ }^{225}$ Thus, positive law need not and should not define itself according to its relationship to monstrous law.

Consistent with his metatheoretical approach, Alexy rejects this positivist position yet merely substitutes conventional justice thresholds that flow from typical natural law concepts. Whereas, Finnis

\footnotetext{
225 Kelsen writes, "only a moral social system is 'law' [...] such a system, in its actual application by the jurisprudence prevailing in a particular legal community, leads to an uncritical legitimation of the state coercive system constituting this community." See Kelsen, supra note 149 at 68-69. See also Alexy, supra note 55 at 46 .
} 
would argue that there are normative outcomes that trump the legal, Alexy argues instead that we will know that the legal has subsided when we are confronted by outrageous outcomes. He writes, "[...] the question is how a conflict between law and morality is to be comprehended conceptually. Neither Hart nor Hoerster would resolve the conflict even in the case of extreme injustice."226 He continues: "[t]he nonpositivist [...] claims that, in the case of extreme injustice, the ethical problem is also a legal problem. The result is that he draws legal conclusions from his moral judgment."227 Alexy asserts that extreme injustice can be determined according to prima facie understood human rights law and comparable justice claims. ${ }^{228}$ He writes, "[t]he threshold beyond which norms forfeit legal character is marked by minimum moral requirements. An example is the elementary human

\footnotetext{
226 Alexy, supra note 55 at 44 .

227 Ibid.

228 Cf Gustav Radbruch, "Five Minutes of Legal Philosophy (1945)" (2006) 26:1 Oxford J Legal Studies 13 at 110 ("There are principles of law, therefore, that are weightier than any legal enactment, so that a law in conflict with them is devoid of validity. These principles are known as natural law or the law of reason. To be sure, their details remain open to question, but the work of centuries has in fact established a solid core of them, and they have come to enjoy such far-reaching consensus in the so-called declarations of human and civil rights that only the dogmatic sceptic could still entertain doubts about some of them.") .
} 
right to life and physical security." 229 There are (common sense) cases in which Alexy's reinterpretation of Radbruch's weak connection theory ${ }^{230}$ holds. However, I argue that even if Alexy's critique is appropriate, it nonetheless falls into positivism's trap of reifying justice thresholds at the expense of resourcing emancipatory claims or macro-normative transformation. Alexy writes:

[I] the case of extreme injustice, [the move] away from the standpoint of morality to the standpoint of the law is not a veiling of the problem, but, rather, the expression of a substantive thesis. And this thesis can be attacked only with substantive arguments, not with a formal argument charging a lack of clarity. ${ }^{231}$

The problem is that this "move to substance" is subject to the epistemic/normative limits of legal subjectivity explored in the foregoing critique of Finnis.

The aggregate justice outcome thus affirmed may be disabled from resourcing justice alterity. The "move

229 Alexy, supra note 55 at 48.

230 See ibid ("The weak connection thesis does not lead to an identification of the law with morality. It says that unjust and therefore immoral norms can be law. So, like legal positivism, it admits of a moral critique of the law and, in this respect, makes possible a critical stance vis-a-vis the law. It differs from legal positivism simply in that beyond a certain threshold, legal character is forfeited. Now, one might think that this alone suffices for uncritical legitimation. Jurists would be inclined to say that the threshold has not been crossed; therefore their legal system possesses at least a minimum moral legitimacy.") .

231 Ibid at 45. 
to substance" succeeds only if it can be posited unquestioningly, and thus remains firmly ensconced within an existing economy of affirmation.

Legal positivists argue that the imposition of the burden of a "move to substance" on legal norms imputes too much meaning to them. Alexy counters that without this, legal norms download too much justice burdening on to the individual. My argument is that macro-normative failure cannot be modeled adequately using either legal positivism or natural law. And even if we were to realize a hybrid of the emancipatory claims contained in both, we would still not have adequate resources for overcoming the antinomical challenges posed by the justice claims contained in legacy subjectivity and or those present in disappointment ${ }^{0 / 1}$.

Take the example of a legal regime that would fundamentally transform existing legal subjectivity, which I will stylize deliberately in order to dramatize justice incommensurabilities. The possibility of such a regime is indicated in recently articulated academic discourse regarding economic de-growth and human de-population, based on the assumption that ecological collapse can only be averted by the forced restriction of the human appropriation of net primary 
production.

Norms that would issue forth from these justice considerations will not conform to an existing economy of affirmation. An actor charged with their implementation - call her the Green Queen - will be forced to make choices regarding how to allocate the burden of transformation. Assume that the Green Queen proceeds objectively in "good faith". Assume also that the consequence of her pursuit of sharp degrowth ${ }^{232}$ and a sudden decline in population will be death and misery to untold numbers, albeit in the interests of securing the survival of the majority. She could readily conjure the claim that the aggregate justice done justifies her choices. Her opponents could readily invoke monstrous law - that the injustices to be done render the regime non-law.

However, and this is the rub, the Green Queen could also claim that the existing regime, in its failure to avoid a destructive pathway, was also monstrous law. Each side would have the credible right to use the category of extreme injustice to respond to the situation; furthermore, each citizen would be in-

232 On the moral claims that could ground degrowth, see Peter G Brown \& Geoffrey Garver, Right Relationship: Building a Whole Earth Economy (San Francisco: Berrett-Koehler Publishers, 2009). 
vited to interpret the law or non-law according to whichever outcome was privileged.

Alexy's "move to substance" presumes that avoidance of injustice will produce clarity as between the Green Queen and her opponents. Yet, his assertion that "the more extreme the injustice, the more certain the knowledge of it" is sadly untenable, especially in light of the experiences of the twentieth century and as the example of degrowth is meant to highlight. ${ }^{233}$

Alexy's response, that "beyond the threshold of extreme injustice, there is at any rate no risk of uncritical legitimation if the minimum moral requirements that mark the threshold can be rationally justified,"234 is not convincing in light of macro-normative challenges fraught with injustice both in the preservation of the existing legal order and in the effort to transform it. The challenges of justice alterity and indeterminacy, explored in greater depth in the subsequent chapter of this thesis, require a different kind of resourcing than Alexy or Finnis can offer.

\footnotetext{
233 Alexy, supra note 55 at 52 .

234 Ibid at 49.
} 


\title{
Beyond Legal Positivism and Natural Law: Duncan Kennedy and Legal Work
}

\author{
In his paper entitled "A Left Phenomenological \\ Alternative to the Hart/Kelsen Theory of Legal Inter- \\ pretation," 235 Duncan Kennedy goes a long way towards \\ identifying the process of normative reproduction as a \\ question of resources, and thus prepares the way for a \\ more differentiated approach to the antinomy of legal \\ positivism and natural law. \\ His approach overcomes the positivist legal onto- \\ logical problem as well as Alexy's affirmation of a \\ contingent alterity of moral or ethical givens. The \\ reproduction of ethical giveness is not Alexy's focus, \\ but the fact that Alexy's moral considerations are as \\ constructed as the law that they line up against \\ leaves his theory begging the question as to how to \\ move beyond this limitation. Kennedy helps to chart \\ the path beyond Alexy. \\ For Kennedy, legal outcomes are the product of \\ work on an alterity. This he defines as something un- \\ knowable that is everything the law could possibly be, \\ to which work is applied in order for it to come into \\ being. According to Kennedy, there is no meaning to \\ 235 Duncan Kennedy, supra note 157.
}


normative reproduction if it is not connected to agency. In this sense, the law is radically deontologized, and this has a delegitimizing effect. As Kennedy writes:

The "ontological" question is whether it is appropriate to regard the determinacy of the rule as applied to the facts, meaning its insuperably binding or "valid" quality at the end of the period allowed for working on it, as its own attribute, something inherent to it. The alternative is that the determinate or indeterminate quality of the rule cannot be understood otherwise than as an "effect," the "effect of necessity" or "effect of determinacy," produced contingently by the interaction of the interpreter's time, strategy and skill with an unknowable "being in itself" or "essential" nature of the rule in the given factual context. ${ }^{236}$

An economy of affirmation gains normative force from the semblance of being that is imputed to the rules, while at the same time thereby impoverishing the capacity of agents to engage reflexively with justice as they do the work of producing outcomes from the rules. The exploration of the tension thereby created within and between agents is at the core of Kennedy's critical legal studies (CLS) phenomenology. As Kennedy explains:

For CLS, the important point is that the antiformalism of $\mathrm{H}[\mathrm{art}] / \mathrm{K}[\mathrm{elsen}]$ presupposes the schema according to which every case is located either in the area of determinacy or in the penumbra or

236 Ibid at 160-1 [emphasis in original]. 
frame. For our purposes, what counts is not that policy analysis is frequently required and appropriate, but that they provide no account of how the situation gets framed as one located in the penumbra or frame, so that there is no determinate right answer available.

In other words, before the policy analysis begins, whatever its content, the interpreter explicitly or implicitly frames the situation as one in which there is a conflict or a gap that exempts him from the elementary duty to apply a clear norm when the facts clearly fit within its definitions. H/K resemble the conceptual jurists and the inventors of interest balancing in that they do not theorize this initial framing. ${ }^{237}$

Kennedy defines the interpreter's task as legal "work", 238 "understood as the transformation of an initial apprehension (Husserl) of what the legal materials making up the system require, by an actor who is pursuing a goal or a vision of what they should require."239 The goal is a (re)articulation or a shift in legal determinacy.

Although Kennedy disputes explicitly the notion of a found or a given legal determinacy, ${ }^{240}$ he asserts that the legal-phenomenological hyle (ư $\lambda \eta)^{241}$ is constrained "in the way a medium constrains any other worker. It constrains only against an effort to make

237 Ibid at 157 [emphasis in original].

238 Ibid at 158 .

239 Ibid [footnote omitted; emphasis in original].

240 See ibid at 159 ("In all these cases, the interpreter works to create or to undo determinacy, rather than simply registering or experiencing it as a given of the situation.").

${ }^{241}$ Kennedy analyses both law as transcendent material and law as medium. I use hyle here to define a substratum to which both concepts refer. 
the materials mean one thing or another." 242

If we accept Kennedy's theory that the resourcing of legal work has a substantive impact on bringing law to be, and thus on law's ontology, we can reach through to the concept of the legal as an expression of resource ideology.

Kennedy uses the definition of ideology, drawn from contemporary legal discourse, as a "universalization project" and "the assertion of a controversial conception of justice, alleged by some to be mere rationalization of partisan interests, but defended by its adepts as serving the interests of all - as well as the interests alleged by its opponents to be merely partial". ${ }^{243}$ He concludes that "[i]deology inflects work, which inflects frames and cores, which in turn provide, in the coherence view, means to further destabilizations of other cores and frames."244

Carrying the analysis further opens up the question of whether ideology also can be seen as a form of legitimation for the (presence or absence of) resources devoted to overcoming justice deficits. By determining what in the economy of affirmation legiti-

Kennedy, supra note 157 at 160 .

Ibid at 162 .

Ibid at 165. 
mates the resourcing of "legal work", legal workers reproduce functionalized forms of normativity. Kennedy writes:

In this view, the body of valid law, that is law that is regarded by legal workers in their initial encounter with the materials as core or frames, is well understood, first, as an historical work product of lawyers, jurists and judges who have pursued (some of the time; consciously or unconsciously) conflicting ideological projects (which may be centrist, in the above sense), and, second, as always but unpredictably subject to destabilization by future ideologically oriented work strategies. ${ }^{245}$

The prediction that no legal work will be done because it will serve no purpose within the legal economy of affirmation becomes synonymous with CLS's definition of determinacy. As Kennedy emphasizes:

The only intelligible meaning of a "right answer" in a case, hard or easy, given the phenomenology above, is that having worked with the time and resources available and according to a chosen strategy, the interpreter can't find an alternative to some particular apprehension of what rule applies and what it requires when applied. In other words, after performing the phenomenological reduction, the "right answer" is the one that is produced by an argument having the "effect of necessity." As to whether there is a right answer in the sense of one available to cognition, CLS takes the position of Kant as to the "thing in itself."246

The analysis of legal positivism in this chapter set out to explore the issue of antinomical burdening and

245 Ibid.

246 Ibid at 170. 
its exclusion through law. Kennedy's analysis is parallel to that of the thesis, emphasizing in the passage just cited how an effect of necessity can be produced so as to relieve an interpreter of the burden of doing legal work.

By contrast, Alexy's natural law argument against legal positivism does not rise to the critical challenge of accounting for the role of legal positivism in reproducing the empirically existing normative economy of affirmation. In this sense, the important point is not whether positivism is discredited. The character of its pervasiveness attracts not only Kennedy's deconstruction, but also begs the question of what epistemological pre-requisites mesh with the threshold characteristics of legitimacy surrounding the resources of legal work.

It is my argument that the disabling of emancipatory outcomes arises not only through the underresourcing of alternative forms of "legal work,"247 as CLS would assert, but even more so out of the failure

247 See ibid at 167 ("And it will often be possible to predict that no such work will be done, because the extant ideological projects empowered through the judiciary are likely in agreement with the initial apprehension, or in agreement that the outcome is not worth destabilizing work. We might anticipate that it would be otherwise if actors with radical or other outlying ideological projects more commonly worked as judges or as influential jurists."). 
to uncover how epistemological thresholds would need to be resourced continuously to make the concealed economy of affirmation around "legal work" illegitimate.

That is, we must inquire into what resourcing is necessary so that we can credibly no longer rely on legitimation through de facto outcomes. When we do not, we fail to do the "legal work" necessary to enable anything other than reproducing de facto outcomes, even if some emancipatory claims are already being realized in those outcomes. 


\title{
But Does the Law Begin and End with the Legal?
}

\author{
Kennedy gives us an insight into the involuted, \\ non-emancipatory quality of legal work that is per- \\ formed within the horizon of legal positivism. This \\ chapter offered a parallel insight into the non- \\ emancipatory effort to forge a straight connection be- \\ tween law and justice through legal work within natu- \\ ral law.
}

Emancipatory justice claims are asserted in both positivist and natural law paradigms. From opposing intrinsic and extrinsic standpoints, both legal positivism and natural law seek to enable law to overcome itself within an existing justice imaginary. The explicit or implicit closure of the open-ended nature of emancipatory claims is credible from a theoretical standpoint. In fact, the epistemic limitations of theory it incapable of going further. Metatheory, by contrast, can investigate the limitations underlying theoretical articulations that an economy of affirmation relies upon.

Justice metatheory has the added task of exploring the justice externalities that epistemic/normative theory aggregates reproduce. This allows us to model shifting configurations of the justice matrix. This 
overcomes the debate about the legitimacy of discrete positions. Their emancipatory claims can all be visualized along with their epistemic/justice-theoretical lacunae.

Accordingly, we might represent the differences in position among Bentham, Kelsen, Hart, Finnis and Alexy as follows:

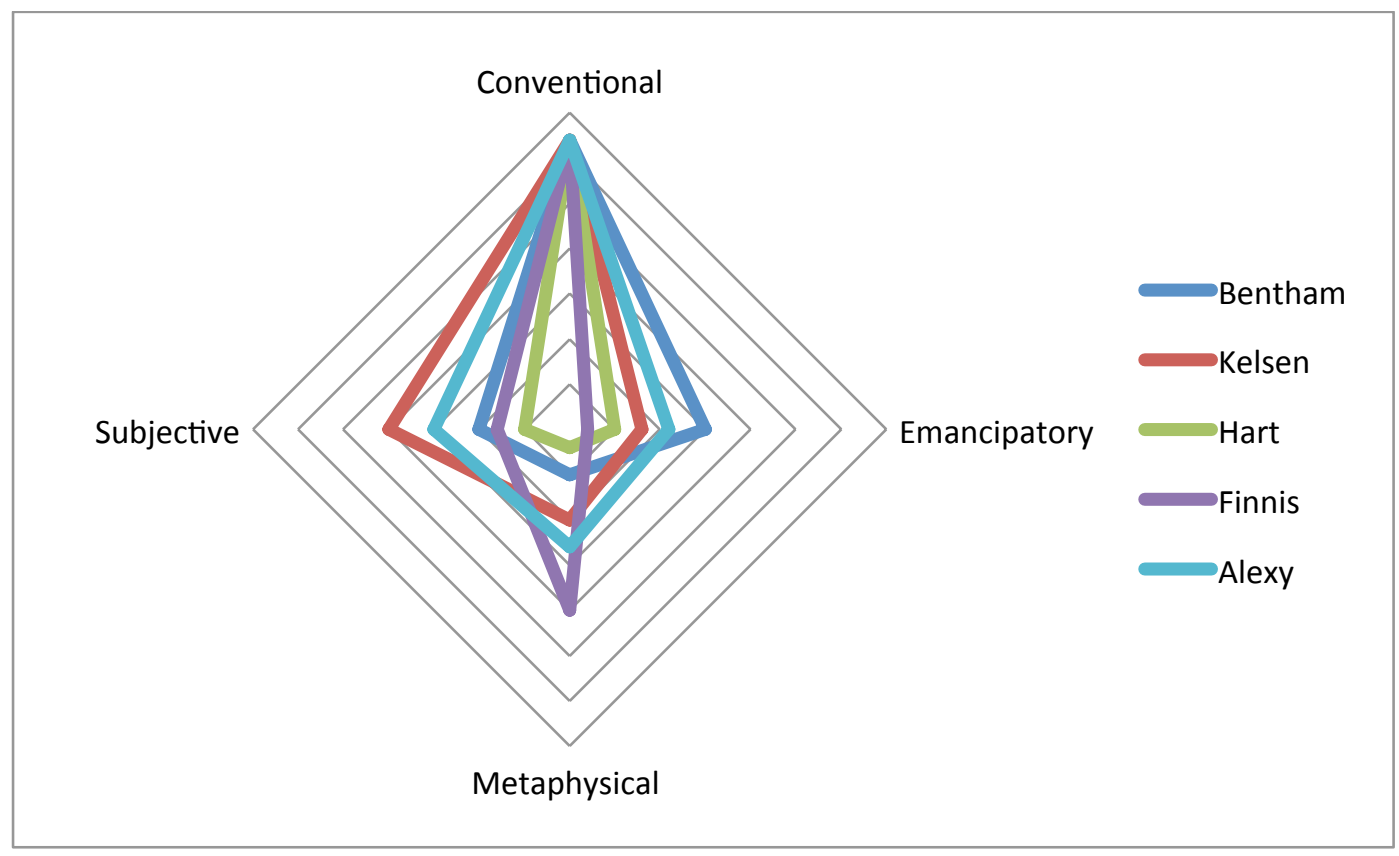

For the reasons we have seen, all end up clustering justice claims around the conventional pole.

The variance between intrinsic to extrinsic is tracked in the relative prominence given to subjective versus metaphysical claims. Legal positivism tends to knit together more closely conventional and subjective claims, whereas natural law tends to knit together 
conventional and metaphysical claims. In all cases, albeit to different degrees, the pull of the conventional pole tends to occlude the emancipatory pole.

The following chapter relies on metatheory to explore the alterity to law recognized within it. This analysis will define equity's emancipatory core, as well as circumscribe the process of its capture resulting in normative stasis. Equity is a longstanding justice conceptualization adjacent to and within the law. ${ }^{248}$

248 See Joseph Story, Commentaries on Equity Jurisprudence: As Administered in England and America, 5th ed (London: V\&R Stevens and GS Norton, 1849) at 45 ("[E]quity must have a place in every rational system of jurisprudence, if not in name, at least in substance." ). 


\title{
Chapter 3: Equity
}

\section{Deficits of the Legal}

\begin{abstract}
In an effort to relate justice to determinism and freedom, Henri Bergson conceived justice as emanating from two sources: a biological impulse to foster the interests of the group, and the grounds of uniquely human free will, exercised towards the fulfillment of social ends. ${ }^{249}$ Yet in analysing positivism and natural law in the previous chapter, we have seen that the intertwining of determinism with freedom penetrates even further into legal affirmations. Whereas legal positivism vitiates choice on the basis of putting the positivist moment above subjective interpretation, natural law negates choice by invoking manifest justice alterity, but then restricting it to a sublation of legacy subjectivity. In both cases, a justice unavoidability - a threshold normative affirmation - resulted.
\end{abstract}

Nonetheless, Justice alterity is a constant Doppelgänger of the legal. The anchorings of alterity sought by Bentham in eudaemonism, Kelsen in the Grund-

249 See generally, Henri Bergson, The Two Sources of Morality and Religion, translated by R Ashley Audra \& Cloudesley Brereton (Notre Dame, IN: University of Notre Dame Press, 1977). 
norm, Finnis in practical reasonableness, and Alexy in an argument from injustice, are all tied down in relation to an epistemic horizon that the law is set against in order to be recognized as such.

Natural law and positive law both strive towards universalization from this anchoring point. Positive law is driven by intrinsic justice claims, natural law by extrinsic claims. Metatheoretical emancipatory justice theory of the sort undertaken in this thesis models legal positivist and natural law unavoidabilities in order to transcend their contingent justice imaginaries.

The normative consciousness of an irreconcilable justice alterity has existed since time immemorial, whether in the Torah as Lifnim Mi-shurat Ha-din (נדלפנ

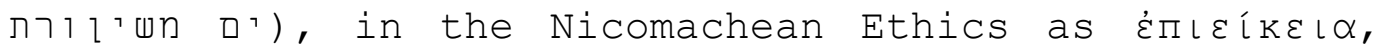
as deployed by the Roman Praetor Peregrinus to facilitate the claims of non-citizens, or in the Code of Edgar to mitigate the heaviness of the law. What has come to be known as equity ${ }^{250}$ is "one of the names un-

\footnotetext{
250 I use the term "equity" here to indicate its generic meaning encompassing heterogeneous historical roots, and "Equity" with a capital E to refer to the body of law traditionally coming under the authority of the Chancellor in common law jurisdictions. When discussing the related concept in Jewish law, I will use משורת לפנים הדין or its transliteration, lifnim mi-shurat ha-din. When discussing the related concept in classical Greek thought, I will use
} 
der which is concealed the creative force which animates the life of the law."251 Traditionally, equity trumps the law, becoming a touchstone for legitimacy. The border between equity and law is fluid. Today law has largely absorbed equity. ${ }^{252}$ Yet, as George Henry Boke cautiously concludes, "[t] he relation between law and equity is found difficult of final statement."253 Whether equity perfects the law's intention, ${ }^{254}$ overcomes its inadequacy, ${ }^{255}$ or undermines the law's $^{\prime}$ authority $^{256}$ it is an expression of justice alterity

the term $\dot{\epsilon} \Pi\llcorner\dot{l} k \varepsilon\llcorner\alpha$ and its transliteration, epieikeia. When discussing the related term in Roman law, I will use the term aequitas.

${ }^{251}$ Puig Brutau, "Juridical Evolution and Equity" in Ralph Abraham Newman \& Sheldon Glueck, eds, Essays in Jurisprudence in Honor of Roscoe Pound (Indianapolis: Bobbs-Merrill, 1962) at 82.

252 In the US by virtue of the Federal Rules of Civil Procedure of 1938. The last province in Canada to adopt concurrent common law/Equity jurisdictions was Ontario in 1881. See generally, Donovan WM, "The Reception of Equity in the Supreme Court of Canada (1875-2000)" (2001) 80 Can Bar Rev 620.

253 George Henry Boke, Cases in Equity (St. Paul: West Publishing Co, 1915) at 1240-41.

254 See Edward Hake, Epieikeia, A Dialogue on Equity in Three Parts (New Haven: Yale University Press for the Yale Law Library, 1953) at 11 ("[...] if the lawe we speake of be a good lawe and well grounded, then the Equity that must be used to the correction of the generalitye thereof cannot be said to be the Equitye of the judge, but of the lawe, for otherwise the lawe muste be a lawe without Equitye, which weare indeede to be a lawe without justice, and so (uppon the matter) to be no lawe but a meare tyranicall constitution.").

255 Christopher Saint German, Doctor and Student (London: Selden Society, 1974) at 77 .

${ }^{256}$ See William Lambarde, Archeion (Cambridge, MA: Harvard University Press, 1957) at 186 ("For on the one part it is thought as hard a thing to prescribe to Equitie any certaine bounds, as it is to make any one generall Law to be a meet measure of Iustice in all particular cases. And on the other side it is said, that if it be not knowne before-hand in what cases the Chancellour will reach forth his helpe, and where not, then neither shall the Subject bee assured how, or when he may possesse his owne in 
distinct from natural law and the legal. Equity is predicated on its antinomical co-existence with the law.

Equity's emancipatory intent is potentially destabilizing of the law and is thus typically contained through a doctrine of the exception. According to Sidney Smith:

Equity and its equivalents have throughout legal history been current terms [...]. [...] [T]he general notion underlying them is that of a doctrine of authority capable of abrogating or ameliorating the hardship which otherwise would ensue either from the literal extension of positive rules of the period of strict law, or from the literal exclusion of cases from those rules notwithstanding that the cases fall within the true spirit of them. ${ }^{257}$

Equity is systemically barred from affirmation independent of the law and asserts its prerogative only through the negation of the law. There is a general consensus that any theory of equity that would attempt to circumscribe it within propositions that are logically coherent and systematic would be inappropriate. Hence equity is amenable to a metatheoretical, con-

peace, nor the Practizer in Law be able to informe his Client what may become of his Action."). In Holdsworth's critical assessment, "the Chancery procedure became a bye-word for dilatoriness and inefficiency." See William Searle Holdsworth, A History of English Law, 7th ed (London: Methuen, 1956) at 342.

257 Sidney Smith, "The Stage of Equity" (1933) 11:5 Can B Rev 308 at 309 . 
stellational approach, which cannot produce a unified, closed canon, but rather illuminates the tensions between contradictory elements. Each star in equity's constellation is as much a part of it as it is in tension with it.

As elaborated in the preceding chapters, much of law's epistemic/normative prerogative depends on its epistemtic/normative reproducibility, its economy of affirmation. Law's blindness, depicted in statues as its equal balance or isonomia (ioovouí), is a threshold synchronicity of mutual expectations that conventional justice claims rely upon. In contrast, equity's justice claims appear at the horizon of disappointment that law inevitably creates.

The further evolution of emancipatory claims encompasses the threshold conventional justice claims of the legal, and depends on a metatheoretical understanding of equity. Building on an analysis of equity that privileges its capacity to embrace justice alterity and antinomical burdening, I advance a theory of how this may be understood to overcome antinomical overburdening, such as disappointment ${ }^{0 / 1}$, which impairs and delegitimizes macro-normative transformation.

Equity archetypally takes two forms: it may call 
upon a person not to invoke his or her rights; or it may be brought to bear as a remedy not available at law. In both instances, the law provides the horizon that equity sublates. Equity is open to a critical review of justice externalities that law depends on and generates. It is enabled to include substantive heterogeneity towards varying justice aggregate outcomes.

As in the foregoing exploration of positivist and natural law conceptions of the legal, my intent in this chapter's metatheoretical analysis of equity is to focus on epistemic/normative unavoidabilities. I argue, that we can see equity's relationship to emancipatory justice by seeking to analogously transcend its historicity. The understanding of equity as an extraordinary remedy tied to law disables it from further evolution towards macro-normative challenges.

Equity mirrors the tensions between the intrinsic emancipatory impetus privileged by positive law (drawn from the internal plasticity of existing law) and the extrinsic emancipatory impetus of natural law (drawn from a normative alterity external to existing law). A right, intrinsic reading of equity affirms law rooted in its capacity for self-correction. The left, extrinsic reading of equity models the overcoming of law by 
confronting the fact that equity is ultimately unknowable.

Through equity's evolution, there is a continual tension and oscillation between its extrinsic, emancipatory justice claim and its intrinsic stabilizing tendency. The extrinsic and intrinsic poles of equity are antinomical and cannot unproblematically occupy the same plane of legitimacy.

What we understand today as equity has flowed from heterogeneous tributaries. As William Walsh contends:

Any definition of equity must necessarily be incomplete and therefore misleading, or so general and vague as to be of no real value. The content and nature of equity can be understood only by a study of its historical development and of the principles and practices which it comprehends. ${ }^{258}$

Each articulation of equity incorporates emancipatory claims, capacity for antinomical enabling, and the exploration of a justice imaginary. It is a mercurial and chimerical concept that immediately invites a metatheoretical analysis. ${ }^{259}$ Ralph Newman describes its multifarious shadings of meaning:

An important reason for the uncertainty as to the

258 William Francis Walsh, Cases on Equity (Chicago: Callaghan, 1937 ) at 1.

259 See Harold Greville Hanbury, Essays in Equity (Oxford: Clarendon press, 1934) at 196 ("Equity has at no time lent itself to very exact definition, and at the present day it is more difficult than ever to lay down its exact scope, the exact field which it covers."). 
nature of equity is the fact that the word "equity" is used in seven different senses; in the sense of what is fair and just, in the sense of natural law, in the sense of a system of law which corrects failures of justice in the main body of the law, in the sense of a theory of justice in which the operation of legal precepts is adjusted to the exigencies of special circumstances, in the sense of a body of law which was administered in the English Court of Chancery when it was a separate court, in the sense, in civil law, of a method of liberal interpretation of code provisions in accordance with the spirit and general purpose of the statute, and, in Anglo-American law, in the sense of a body of legal precepts which introduce into the law, in suits for specific relief, criteria of justice which are based on higher ethical values than those which are ordinarily required in actions for damages. ${ }^{260}$

When attempting a metatheoretical examination of equity, it makes sense therefore to identify, if only in broad brushstrokes, its various historical iterations, paying attention to how the tension between its intrinsic and extrinsic dimensions has been contained and reconfigured within various legal traditions and historical periods. ${ }^{261}$

I will examine in turn Jewish, Classical Greek, Roman, and English conceptualizations in order to highlight shifting relationships between intrinsic and

\footnotetext{
260 Newman, supra note 80 at 403.

261 On the notion of legal traditions see H Patrick Glenn, Legal Traditions of the World: Sustainable Diversity in Law, 3d ed (Oxford: Oxford University Press, 2007). I do not here seek to review the treatment of equity in all legal traditions. Rather, I have selected strong articulations of equity that reveal the interplay of its intrinsic and extrinsic conceptualizations.
} 
extrinsic equity. ${ }^{262}$ Equity in its Jewish law origins was oriented toward the extrinsic confrontation with an unknowable antinomy to the law. Equity invoked God's irreducible justice and mercy. In classical Greece, Aristotle's conception of equity marked an intrinsic turn. Equity could intrinsically correct law's inadequate assertion of a universalizing norm. Roman aequitas revealed a new form of legal subjectivity crystallized around the efforts of the Praetor to produce equitable outcomes for the non-subject of law (the non-citizen).

English Chancery displayed a deep ambivalence between the intrinsic pole of royal prerogative and the justice alterity of the King's "conscience." The Chancellor represented an extrinsic aspect of equity, but as sovereign authority increasingly bound his function, conscience was inflected from being the voice of justice alterity to producing an even deeper adherence to existing normative conventions. ${ }^{263}$ At the same time,

262 Pettit wrote, "[i]t is [...] not really possible to define [Equity] successfully; it can only be described by giving an inventory of its contents or in [...] historical terms." Philip Henry Pettit, Equity and the Law of Trusts, 11th ed (Oxford: Oxford University Press, 2009) at 1.

263 As Rotman points out, legal formalism in the nineteenth century, led "over time, however, [to] the increasing judicial reliance upon accepted categories of fiduciary relations [and] diminished analysis of the fiduciary concept. Further, the grouping of fiduciary relations into categories ceased to be undertaken sole- 
the mixture of prerogative and justice alterity laid the groundwork for the fiduciary relationship, explored in the next chapter.

\section{Lifnim Mi-shurat Ha-din (ים משיןורת הדלפנ)}

In his account of the origins of equity, Leonard Rotman traces one of its major tributaries back to the Jewish concept of משלפ משים (lifnim mi-shurat ha-din), actions that are "beyond the line of the law."264 He notes that in lifnim mi-shurat ha-din, "we can see the distinction between law (halakhah, in the form of strict rules and procedures, and Equity, as understood through the more ample notions of justice, fairness, and right." ${ }^{265}$ Newman gives a parallel reading to 1 As he puts it, lifnim mi-shurat ha-din can be

\footnotetext{
ly for purposes of jurisprudential convenience and reference, but became itself a prima facie basis for determining relationship fiduciarity. Putative fiduciaries bore the onus of demonstrating that they were not fiduciaries without having had any substantive indication of the fiduciary nature of their interactions." See Leonard Ian Rotman, Fiduciary Law (Toronto: Thomson Carswell, $2005)$ at 67 .

264 Rotman, supra note 227 at 163.

265 Ibid at 164.

266 Newman reiterates the difficulty of defining הדי משורת לפנים conclusively. He notes, "that the concept has not been used consistently throughout the tradition, but rather evolved from a strictly moral, extra-legal standard in the talmudic period to a fully actionable legal norm in medieval times." Louis E Newman, Past imperatives: Studies in the History and Theory of Jewish Ethics (Albany, NY: State University of New York Press, 1998) at 18 .
} 
the morally praiseworthy action of doing more than the law requires or, as we would say, going above and beyond the call of (legal) duty. [...] [This] suggests that Judaism does indeed recognize a type of moral action that is not embodied in the halakha, [...] and that the law is not invariably just, so that in fulfilling one's legal duty one does not always discharge one's moral duty. ${ }^{267}$

H.H. Cohn defines it as "a sphere which is beyond strict law, where the letter of the law is no longer decisive."268 Robert Eisen draws out a further dimension relating to the operation of internal conscience:

[T]he rabbis did indeed recognize a category of ethics not mandated by divine directive. As such it reflects the belief that all people have a natural moral conscience and that morality is not reducible to halakhah alone. ${ }^{269}$

At the same time as distinguishing lifnim mi-shurat ha-din from halakhah, the commentators are careful to insist upon the intimate connection between the two.

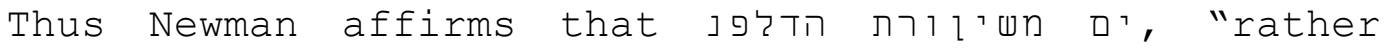
than standing in opposition to the law, [...] is in fact part and parcel of one's legal responsibility in the broadest sense."270 Eisen also distinguishes this position, noting that "lifnim mi-shurat ha-din is itself a directive within the halakhic system and therefore in

267 Ibid at 230 .

$268 \mathrm{HH}$ Cohn, "Ancient Jewish Equity" in Ralph Abraham Newman \& René Cassin, eds, Equity in the World's Legal Systems: A Comparative Study, Dedicated to René Cassin (Brussels: Établissements Émile Bruylant, 1973) at 45 .

269 Robert Eisen, "Lifnim Mi-Shurat Ha-Din in Maimonides Mishneh Torah" (1999) 89:3/4 The Jewish Quarterly Review 291.

270 Newman, supra note 266. 
no sense an extra-legal norm."271

Accordingly, two primary readings emerge. On the one hand there is an intrinsic emphasis, where the law contains its own self-overcoming. On the other hand, there is an extrinsic emphasis, where law's overcoming is a necessary step towards the realization of its essence. In both cases a relationship to justice alterity is asserted. In the former, the law seeks to incorporate the point of normative otherness as always already having been part of law.

This embrace of alterity means that the law opens up to transformation, but remains normatively ascendant. Plus ça change, plus c'est la même chose. In the latter case, the law must confront the fact of its own invalidation. The law can only be legitimate to the extent that it seeks to be transformed by the realization of its own inadequacy. The consequence of an extrinsic equity emphasis is the risk that the law may be unmasked as no law at all.

The tension between whether ניפ משיו מרת מים obligates us not to stop at the strict obeisance of (positive) law, or to legitimate the law through our own judgment in apposition to it (natural law), reflects a

271 Eisen, supra note 269. 
constellational structure. All forms of "equity' explored here manifest this intrinsic/extrinsic antinomy. Kirschenbaum underscores this point:

As a mystic has put it, din "law", biblical law in all its majesty and as it is interpreted and explicated by holy tradition, represents the command of the Lord. Lifnim mishurat hadin in its widest connotation as the deviation from the formal law in the interests of hayashar ve-hatov [that which is upright and good], hassidut [piety and saintliness], and kedushah [holiness], represents His desire. Jewish law lays down that which the Lord commands; it aspires to that which He desires. ${ }^{272}$

Upon closer examination, the justice alterity of is tilted towards an extrinsic, aspirational justice. Its emancipatory claim extends beyond an economy of affirmation based on law revealed at a decisive moment of divine authority.

As Eisen notes, "[a] person is a hasid and exhibits [...] lifnim mi-shurat ha-din if he waives his exemption from a task that compromises his dignity. That is, he displays in this act the capacity for meekness."273 Meekness has a special significance here, distinct from any pejorative connotation. Rather, according to Eisen, "[m]eekness is a propaedeutic to the

\footnotetext{
272 Kirschenbaum, "Jewish Law and Aristotelian Equity" in Alfredo Mordechai Rabello \& Israel B Greene and Sara Mann Greene Fund for Equity Studies, eds, Aequitas and Equity: Equity in Civil Law and Mixed Jurisdictions (Jerusalem: Harry and Michael Sacher Institute for Legislative Research and Comparative Law, the Hebrew University of Jerusalem, 1997) at 65.

273 Eisen, supra note 269 at 305.
} 
imitation of God, for it takes the focus away from the self and places it on God, while at the same time allowing us to behave with impassivity, especially in situations of insult."274

ים משין typically arises in cases where a rabbi interacts with a Jew of no special status. More specifically, "in practically every halakhic discussion in the Babylonian Talmud most often the rabbi waives a legal right[...]."275 An instructive example can be found in the following aggadah:

Rabbah bar bar Hannah hired some porters to carry a jug of wine for him. They broke it and he took their cloaks. They went before Rav. He said to Rabbah bar bar Hannah, "Go and give them their cloaks." Rabbah bar bar Hannah asked, "Is this the law?" Said Rav, "(As Scripture says), "Follow the ways of the good' (Prov. 2:20a)." They then stood and cried out to Rav, saying, "We are poor and we worked for him the entire day; we are hungry and have nothing to eat." So Rav said to Rabbah bar bar Hannah, "Go pay them their wages." Rabbah bar bar Hannah asked, "Is this the law?" Said Rav, "(As the rest of the verse says), 'And keep to the paths of the just'."276

Of particular relevance is the fact that Rabbah bar bar Hannah was within his halakhic (legal) right to retain the garments as compensation for the negligence. Not only does the Rav mandate their return, but

274 Ibid at 314

275 Ibid at 309.

276 Nahum M Sarna, Marc Zvi Brettler \& Michael A Fishbane, Minhah le-Nahum: Biblical and other Studies presented to Nahum M. Sarna in Honour of his 70th Birthday (Sheffield, UK: JSOT Press, 1993). 
he also requires the payment of their wages. Talmudic

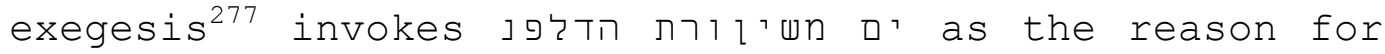
this reversal of outcome.

What makes this result characteristically equitable is the accountability of the socially enabled, here Rabbah bar bar Hannah, to an outcome whose measure of justice is other-regarding. What would be the injustice visited upon Rabbah bar bar Hannah, if the halakhic outcome won out? His methexis - participation in the pure form - of divine justice, of radical justice alterity, would be diminished and his conscience therefore burdened.

In this reading, the halakhah can be identified with (normally legitimate) self-interest, and by implication with an eudaemonic claim. Rabbah bar bar Hannah asks the Rav twice about the legal ruling, i.e. what his legitimate expectation should be. In both instances he is exhorted to abstract from his rights and to pursue the path of the good and just.

The emphasis here is on process. The Rav does not insist on a specific outcome, but rather that a pro-

\footnotetext{
277 See Eisen, supra note 269 at 310 ("Even though this case is often used as the prime example of lifnim mi-shurat ha-din, that principle is never actually mentioned in this passage. It is Rashi who understands Rav's ruling as an exhortation to Rabbah to act lifnim mi-shurat ha-din.") .
} 
cess of justice alterity be resourced. Rabbah bar bar Hannah, although entitled to a legal remedy, is required to forego his right in favour of the pursuit of a heterogeneously contextualized justice.

A further important Talmudic example can be found at bBer 7a:

Whence do we learn that the Holy one who is blessed prays? It is written: "I will bring them to my holy mountain and I will make them joyful in my house of prayer [lit. the house of my prayer]" [Is 56:7]. It does not say "their prayer," but rather "my prayer." Thus we learn that the Holy One who is blessed prays. What does God pray? Said Rav Zutra bar Tuvia, Rav said, "May it be my will that my mercy may suppress my anger and my mercy prevail over my other attributes, so that I deal with my children according to the attribute of strict mercy and on their behalf act [lit. enter] lifnimm i-shur ath a-din."278

The aspirational aspect of even divine obligation is expressed here as a form of other-regarding. The source of law and justice is seen here to be analogously duty-bound to a process of self-overcoming to the benefit of the other. This is the case even if this other has not earned such treatment, or in fact merits the opposite. It is significant that a legal question is resolved with recourse to the concepts of process, path, justice, self-overcoming (otherness to self), and other-regarding.

278 Newman, supra note 266 at 68 . 
How does lifnim mi-shurat ha-din address the disappointment ${ }^{0 / 1}$ antinomy described in chapter one? Once equity has been done, it neither reifies what has not and cannot be transformed, nor eliminates the tensions that led to the antinomical burden. Both parties are enabled towards their legitimate interests, beyond the limits of their own agency.

Disappointment ${ }^{0}$ is addressed because the point of departure is not restrained by legacy subjectivity. Rabbah bar bar Hannah is brought to act in a manner other than what his reasonable expectations would produce. Disappointment ${ }^{1}$ is circumvented by the fact that no pre-existing or future expectations are affirmed. Although Rabbah bar bar Hannah does not receive satisfaction, the law remains unquestionably valid. The negation of the conventional expectation here is part of the justice outcome. The outcome does not answer the justice expectations of an existing economy of affirmation, which persists in parallel. In this sense, justice alterity is seen to trump the limitations of subjectivity

The heart of imposition of an emancipated agency on subjectivity through justice alterity. The emancipatory moment is 
that of liberation from the justice deficit in the lack of relationship/agency produced by a halakhic normative/epistemic horizon. ${ }^{279}$ In breaking the identification of övtos-voulkós - existence and legal rule an otherness to law is reinstated without this transgression itself being reified.

In lifnim mi-shurat ha-din, the agency of the disabled transgressor, here a common distinguishing characteristic of the cases, is transformed by the selfovercoming of the enabled aggrieved. The antinomical justice burden is placed upon the more resourced party.

The metatheoretical moment is expressed in this resourcing of the non-identical. The aggrieved is enabled not to require the outcome that would block the emancipatory dimension of justice alterity. A liberation from self-regarding is the prerequisite of acting "on behalf" of the wrongdoer. Consequently, הדלפנ ים משיוזרת demands a greater justice of selfovercoming by the enabled in the face of the failure of the other.

הדיl משורת לפנים provides us with an archetypal

279 The invocation of a parallel non-affirmative justice horizon will be taken up in greater depth in Chapter 4 in the section on Adorno's emancipatory epistemology. 
exploration of the elements of equity. As we explore its re-configuration in other legal cultures and epochs, it will be valuable to recall the characteristics of subjective overcoming, other-regarding, resourcing of process, justice alterity, agency without absolute equality of liability, non-satisfaction of expectations derived from a legal economy of affirmation, and finally a form of subjective enabling that notionally counterbalances disappointment ${ }^{0 / 1}$.

As we noted in the discussion of legal positivism and natural law, legal subjectivity circumscribes the justice imaginary, and thus in turn the possible forms of legitimacy and justice alterity. Each normative framework also produces justice unavoidabilities. Equity reiterates the intrinsic/extrinsic archetypes of legal positivism and natural law, notably their obverse strategies for containing and emancipating the law.

By contrast, however, equity does not suppress the antinomical tension, as do legal positivism and natural law each by denying the legitimacy of the other. Rather, equity actually embodies the tension. In this sense, the emancipatory justice claim shadows the evolution of equity 


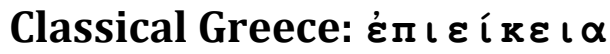

Multiple normative frames are central to classical

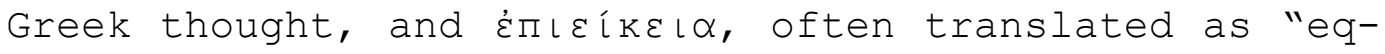
uity", is closely connected to vouós, often translated as law. The problematic character of these translations helps to reveal the relations between the terms in Greek. As Shellens explains:

The term vouós refers not only to what we commonly call "law", but also to the principles of customs, morals, manners and habits - to everything which is a principle of order within social life. Thus we read in the Rhetoric that courage, as well as temperance and justice, is based on the vouós, and that they are in accord with the dictates of the vouós. The vouós, so to speak, is at work wherever people submit to, and feel bound by, propositions deciding the worthiness or unworthiness of a certain behavior within a given community. [...] "Norm" [...] is probably a more satisfactory translation. Whether such a norm is written or not is unimportant. The decisive characteristic of a norm is that it is fixed (in some way) and enacted. ${ }^{280}$

Steve Wexler makes clear, furthermore, that "for Aristotle, vópos (nomos), law or custom, is tókıs, ar-

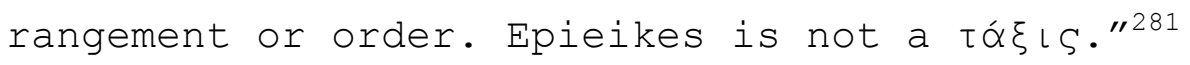

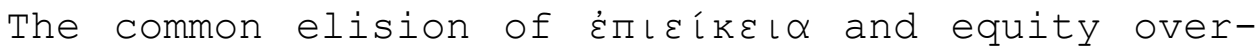
looks the problems of translating from Greek through Latin into English. Wexler points out that the presumption that equity and equality are "linguistically

280 Shellens, supra note 97 at 74 .

281 Steve M Wexler \& A Irvine, "Aristotle on the Rule of Law" (2006) 23:1 Polis: The Journal of the Society for Greek Political Thought 116 at 98 . 
related" is misleading. He writes, "[e]pieikes is not equality, or rather on the one hand it can be equality, but on the other hand it does not have to be."282 He continues,

Epieikes is an unsystematic natural law. [...] Unsystematic natural law is a contradiction in terms. Law is arrangement, so natural law must be a natural arrangement. It must be systematic. Epieikes is unsystematic but it is natural in that people are supposed to just know it. This is one of the foremost characteristics of natural law: people just know it. Neither epieikes nor "equity" is equality. Both are a matter of knowing when equality is right and when equality is not right. ${ }^{283}$

After a considerable process of detranslation, Wexler reaches the conclusion that the most faithful constel-

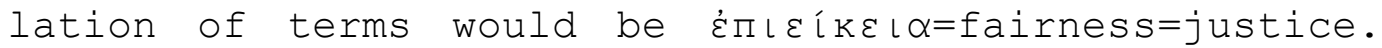
For all these reasons I will retain the term Énı when talking about the specific characteristics of equity in Classical Greece.

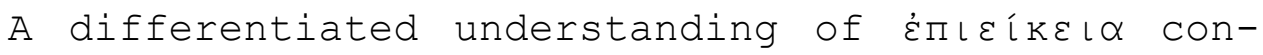
fronts the ambiguity and fragmentary quality of Aristotle's texts. Wexler describes the works of Aristotle as one-off, hand-made antiques. ${ }^{284}$ The primary diffi-

\footnotetext{
282 Steve M Wexler, On the Other Hand: Retranslating Aristotle on law (2008) at 97, online: < http://faculty.law.ubc.ca/wexler/pdf/on_the_other_other_hand.pdf> 283 Ibid.

284 His characterizes his own project as giving rise to "retranslations - which might almost be called 'detranslations' - [they]
} 
culty is that Aristotle's texts have been made to conform to a posthumous understanding of the ordering of his thought. According to Wexler:

Almost all the English translations of Aristotle use at least occasional Latin, and all translate in light of the commentaries. They make Aristotle articulate the philosophy that scholars have found in him. They are interpretations, not translations. ${ }^{285}$

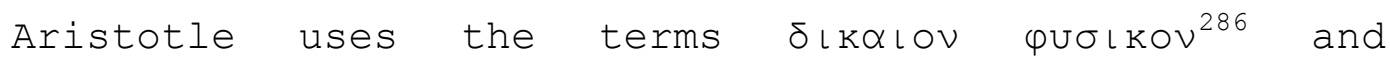

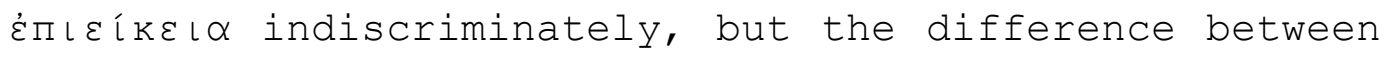
them is significant.

Wexler stresses their unsystematic nature and their ambivalent relationship to other characteristics

are an attempt to make clear how unsophisticated Aristotle's writings are." See ibid at 2 .

285 Ibid at 10.

286 Aristotle's expositions of $\dot{\varepsilon} \Pi \varepsilon \dot{l} \mathbf{k} \varepsilon\llcorner\alpha$ are in the Nicomachean Ethics and the Rhetoric. In them, Aristotle makes a basic distinction between fundamental and ordinary laws, between the customary, natural, and universal in law, and the local, conventional, and ordinary enactments. Haines asserts that, "[to] Aristotle justice was either natural, as in accordance with nature, and hence universal; or local and conventional, as applicable to a particular place. The higher law, as Aristotle conceived it, was unwritten, universal, eternal and immutable, and in accordance with nature." See Charles Grove Haines, The Revival of Natural Law Concepts, 4th ed (New York: Russell \& Russell, 1965) at 2. Shellens explains that, "particular law is that law which is applied by a particular state in administering justice; general law is that law which, being acknowledged and recognized by everybody, is not confined to a particular state. The latter is logically unwritten law". See Shellens, supra note 62 at 75. Natural law, or $\delta$ lkolov $\varphi v \sigma l k o v$, according to Aristotle, is anterior to the positive laws [...] from which the latter take their origin. To render a political order stable there must be administered in it a justice independent of arbitrary rules or of human enactments and superior to every individual interest." See E Burle, Essai historique sur le développement de la notion de droit naturel dans l'antiquité grecque (Ulan Press, 2012) at 178. Haines also points out, that natural law, "[...] is universal and divine, and positive law, is local and human [...]". See Haines, supra note at 2. 
of the law:

In summary, when we say "just", on the one hand we mean "equal", on the other hand, we mean "in accordance with law". When justice is equality, on the one hand, "equal" means "the same", on the other hand, it means with "relevant differences taken into account". These are four different justices. Two of them are opposites of each other in one dimension and two are opposites in another dimension, but on the other hand, they are all four the same. They are all internally consistent and there is yet another justice that is the opposite of all four in a different dimension. This justice is not internally consistent. It is unsystematic. ${ }^{287}$

Wexler also draws a further distinction concerning the non-affirmational core of Éாı

Natural law is always supposed to have the form: it is always wrong to do such and so or it is always right to do such and so. The form of epieikes is totally different. In the first place there is no "always" in epieikes. In the second place, there is no "such and so" in epieikes. Most important, there is no "right" in epieikes. Epieikes does not tell us what it is right to do. Epieikes is like Socrates' daimonion. It tells us what not to do. It says this or that particular result of the legal arrangement is wrong and must not be allowed. 288

This willingness to adjudicate at the level of antino-

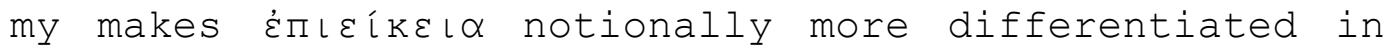
addressing justice alterity .

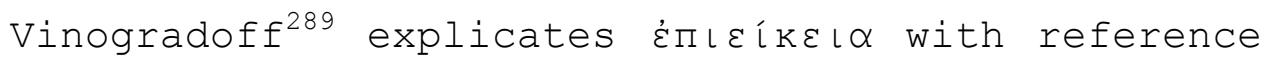
to the problem of accommodating unlike elements:

287 Steve M Wexler, supra note 282 at 4.

288 Wexler \& Irvine, supra note 281 at 98.

289 Actually, Павел Гаврил́ович Виноградов. 
If justice is to be done in society, account has somehow to be taken of proportion. As Aristotle puts it, we have to reckon with geometrical and not with arithmetical relations. ${ }^{290}$

Vinogradoff presents us with a political equivalent of equity ${ }^{291}$ : "to every one according to his needs; from every one according to his capacities". ${ }^{292}$ He also stresses the antinomical characteristic of this formulation:

[...] if we start from two entirely disconnected terms, we are bound to arrive at two independent results and no method is provided for effecting a rational combination between them. The problem is somewhat simpler in law than in constructive policy. While in the latter case the choice of measures must be left to wisdom, in the former an approximation to justice may be obtained by the exercise of equity.[...] Equity in this sense appears as a "correction" of law. Its estimates are formed not only in accordance with abstract general rules but with a view to the particular circumstances of the case. The Greeks called it

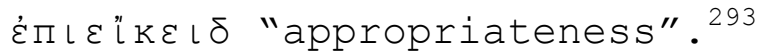

Vinogradoff's analysis reveals two relevant extrinsic

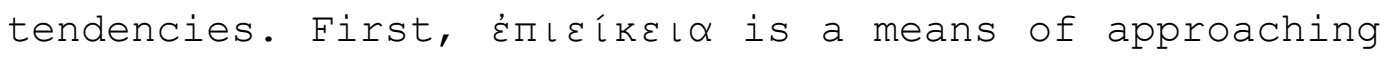

\footnotetext{
290 Wexler \& Irvine, supra note 281 at 98.

291 Erroneously citing Charles Fourier rather than Louis Blanc (later relied upon by Marx) for this version of the principle. 292 Vinogradoff, supra note 176 at 3. This phrase is attributed to Morelly in Eisen, supra note 269 at 310 ("I. Nothing in society will belong to anyone, either as a personal possession or as capital goods, except the things for which the person has immediate use, for either his needs, his pleasures, or his daily work. II. Every citizen will be a public man, sustained by, supported by, and occupied at the public expense. III. Every citizen will make his particular contribution to the activities of the community according to his capacity, his talent and his age; it is on this basis that his duties will be determined, in conformity with the distributive laws.") .

293 Vinogradoff, supra note 176 at 3.
} 
justice questions that arise from unequal or heterogeneous terms. This engenders an antinomical burden, which is unresolvable using conventional methods.

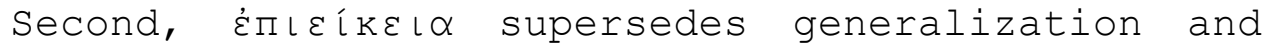
embraces the specific case without calling the validity of the law into question. The epistemic presumptions related to the legitimacy and generality of law are both retained and bracketed. On this understanding, $\dot{\varepsilon} \Pi \varepsilon\{k \varepsilon l \alpha$ is the correction of the law's shortcomings. ${ }^{294}$

In the Laws, Plato has the Athenian Stranger describe law-making in terms parallel to $\dot{\varepsilon} \Pi \operatorname{li} \mathbf{k} \varepsilon\llcorner\alpha$ as follows:

First, [the legislator] desires that his laws should be written down with all possible exactness; in the second place, as time goes on and he has made an actual trial of his decrees, will he not find omissions? Do you imagine that there ever was a legislator so foolish as not to know that many things are necessarily omitted, which some one coming after him must correct, if the constitution and the order of government is not to deteriorate, but to improve in the state which he has

294 See Shellens, supra note 97 at 77 ("We know from practical experience that in certain instances a specific conduct may be illlegal' and still be 'equitable'; that is, in accordance with the principles of justice and righteousness. In such cases we should not adhere to the wording of the law, but look at the intentions of the lawgiver and settle the dispute by 'arbitration.' Does this imply that legal justice should be abolished and replaced by something else called 'equity'? Far from it. When we check Aristotle's statements we see quite another picture."). 
established? ${ }^{295}$

Aristotle mirrors this when he writes:

What creates the problem is that the equitable is just, but not the legally just but a correction of legal justice. The reason is that all law is universal but about some things it is not possible to make a universal statement which shall be correct. In those cases, then, in which it is necessary to speak universally, but not possible to do so correctly, the law takes the usual case, though it is not ignorant of the possibility of error. And it is none the less correct; for the error is not in the law nor in the legislator but in the nature of the thing, since the matter of practical affairs is of this kind from the start. When the law speaks universally, then, and a case arises on it which is not covered by the universal statement, then it is right, when the legislator fails us and has erred by over-simplicity, to correct the omission - to say what the legislator himself would have said had he been present, and would have put into his law if he had known. Hence the equitable is just, and better than one kind of justice - not better than absolute justice, but better than the error that arises from the absoluteness of the statement. And this is the nature of the equitable, a correction of law where it is defective owing to its universality. ${ }^{296}$

The notion that Énı $\mathbf{i k \varepsilon} \iota \alpha$ is a correction of the law

lives in uneasy tension with the notion that it is "above the law".

P.J. Zepos writes that Herodotus, the sophists (Gorgias), and Plato "noticed the preponderance of

295 Plato, Laws, translated by Benjamin Jowett (Champaign, IL: Project Gutenberg, 199AD) at 94, online: <http://www. gutenberg.org/ebooks/1750>.

296 Aristotle, The Nicomachean Ethics, translated by David Ross (Oxford: Oxford University Press, 2009) at 98. 


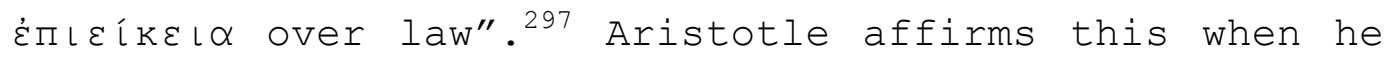
writes:

These, then, are pretty much the considerations that give rise to the problem about the equitable; they are all in a sense correct and not opposed to one another; for the equitable, though it is better than one kind of justice, yet is just, and it is not as being a different class of thing that it is better than the just. The same thing, then, is just and equitable, and while both are good the equitable is superior. ${ }^{298}$

This pre-eminence for Énı justice quality explored with respect to משיו 口י

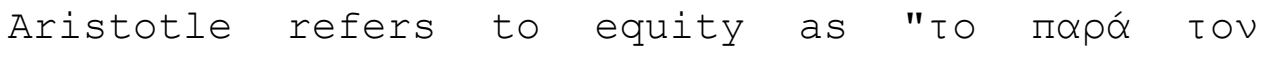

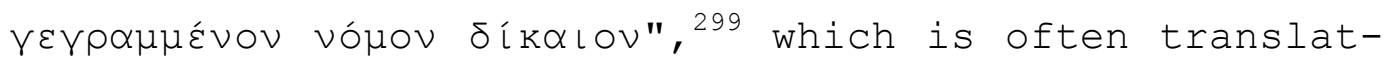
ed as being "justice which goes beyond the written

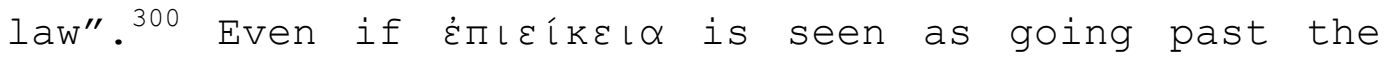
limitations of law, it does not, unlike $\delta\llcorner$ kolov

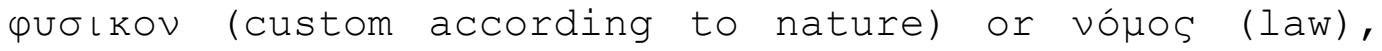
take an affirmative form. We cannot determine what Éாıદíkı $\alpha$ means in the absence of an antinomical burden .

Énı

297 PJ Zepos, "Equity in Greek Law" in René Cassin \& Ralph Abraham Newman, eds, Equity in the World's Legal Systems: A comparative Study, dedicated to René Cassin (Brussels: Établissements Émile Bruylant, 1973) at 434 .

298 Supra note 263 at 98.

299 Aristotle, Aristotelis Ars Rhetorica, translated by Moerbeke von William (Lipsiae: B. G. Teubneri, 1867) at 143.

${ }^{300}$ Shellens emphasizes that the translation should rather read "alongside the law". See Shellens, supra note 97 at 77. 
negation. It negates the standing of both $\delta\llcorner$ ko ıov

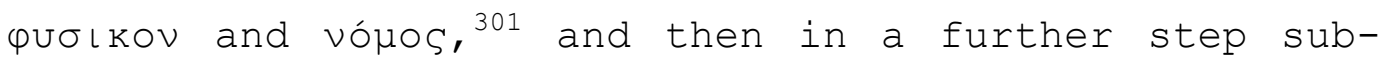
lates itself by not conforming to any fixed status. Shellens writes:

Whenever Aristotle discusses equity at greater length he posits a direct relation between equity and the unwritten law [...] The "norms" or "rules" of equity are not of the kind that could be written down. That is their very essence. [...] But this kind of "unwritten law" is not natural law. Nor does it help to solve the real problem of natural law. ${ }^{302}$

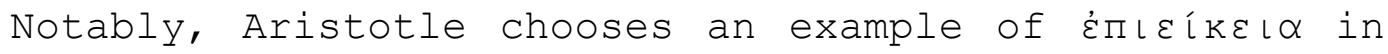
the Nicomachean Ethics that mirrors characteristics of •ים משי ון ורת הדלפנ.

Where a litigant has an actionable legal right (rov vouov $\beta$ onӨov) ${ }^{303}$ - that is, he or she is backed by

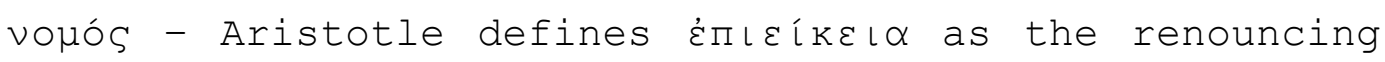

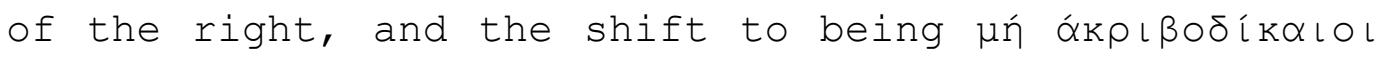
- one who does not stand on rights unduly. ${ }^{304}$ The $\mu n$

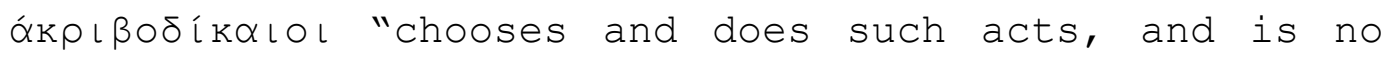
stickler for justice in a bad sense but tends to take less than his share though he has the law on his

\footnotetext{
301 Shellens writes, "[w]e know from practical experience that in certain instances a specific conduct may be 'illegal' and still be 'equitable'; that is, in accordance with the principles of justice and righteousness." see ibid. 302 Ibid at 78 .

303 Aristotle, Ethica Nicomachea (Oxford: Clarendon Press, 1828) at 156 .

304 Non-prejudicial, non-discriminatory.
} 


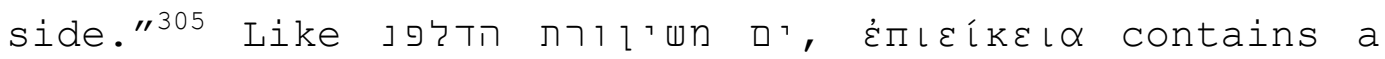
deliberate embrace of justice alterity.

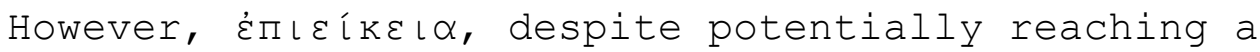

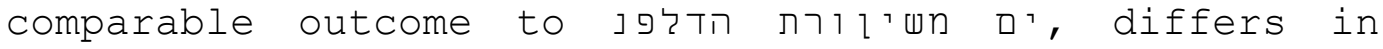
that it solidifies the role of equity as a constant parallel normative force. Énı ים משי in that it no longer represents the exceptional existence of an obligation that exceeds the requirements of

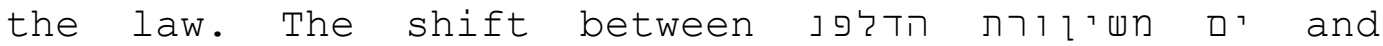

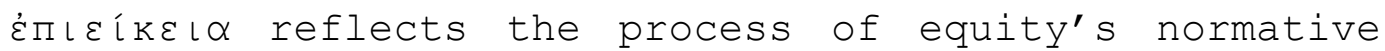
assimilation. It is a subtle shift in the balance between intrinsic and extrinsic elements.

The reasoning of the Rav left it up to individuals to decide whether they were enabled to embody ים משים ים משית היוזת הדלפנ The equity embraced in explicitly appealed to the capacity to overcome human justice. Already in غ̇กıદíkı $\alpha$ we see the shift to the perfection of humanly articulated justice. The extrinsic justice alterity of נים משיו מרת הדלפ is shifted to the intrinsic consummation of law. This has a direct impact on justice alterity and the emancipatory claim. On the one hand, the economy of affirmation sur-

305 Supra note 303 at 99. 
rounding ים משים is inconclusive. On the other hand, halakhic failure is unimaginable. This produces an economy of affirmation that embraces antinomy, and yet leaves halakhah untouched.

Subjective agency is called upon to resource this burden. The Trom, or adherent, is called upon to overcome self, to leave the confines of legal subjectivity, without the security of being supported by a hala-

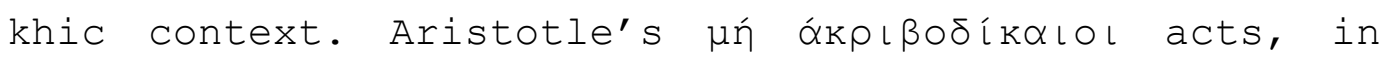
contrast, to a significantly larger degree within the confines of a legal person. The subjectivity thus affirmed is an important step away from the limitless

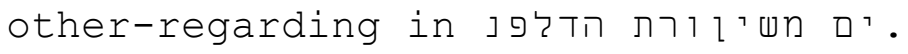

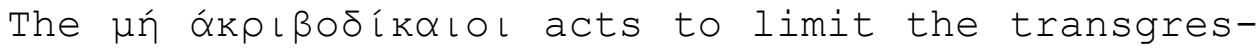
sion of legitimacy inherent in classical Greek citizen subjectivity. The emancipatory claim evinced in places methexis with divine justice above any subjectivity. The тоा is only truly emancipated when subjectivity, and hence legal rights, are sacrificed to a form of justice alterity that overlaps with a form of other-regarding.

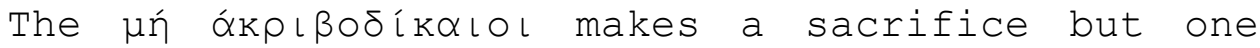
significantly more connected to the reproduction of the law "defective owing to its universality." The $\mu n$ 


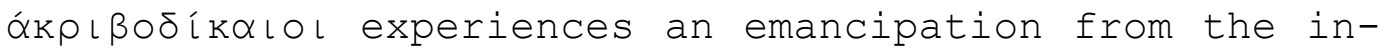

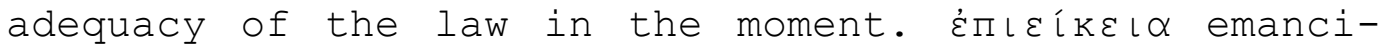
pates the subject from the burden of the law's failure, but does not demand the same degree of antinomical negotiation.

\title{
Roman Aequitas
}

\author{
There are multiple normative conceptions feeding \\ into the evolution of equitable concepts. The related

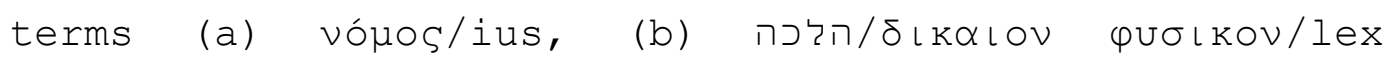

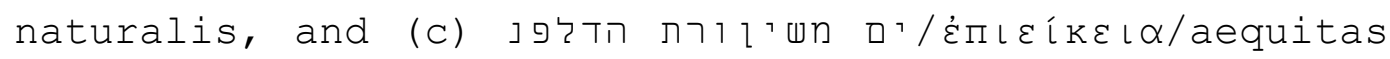 \\ came into being both marked by their predecessors, as \\ well as evolving sui generis to respond to societal \\ needs.

\begin{abstract}
Pollock writes, "the terms lex naturalis, naturae, and ius naturalis came into Roman law as deliberate translations of Greek expressions. ${ }^{306}$ They were then used to express ideas that were already evident in Ro-

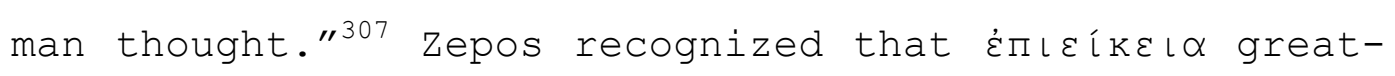
ly influenced Roman jurists like Cicero and Seneca and
\end{abstract}

\footnotetext{
306 "The Roman jurisconsults, in order to account for the improvement of their jurisprudence by the Praetor, borrowed from Greece the doctrine of a Natural state of man - a Natural society - anterior to the organization of commonwealths governed by positive laws." See Maine, supra note 209 at 68.

307 See generally Frederick Pollock, Essays in the Law (London: Macmillan, 1922).
} 
contributed to the Roman notion of aequitas. ${ }^{308}$

\author{
Falcón y Tella's etymology of the Latin aequitas \\ illustrates that it drew upon concepts apposite to

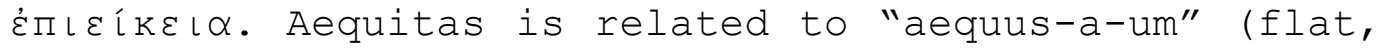 \\ equal, straight), and "aequor" (the plane of the coun- \\ tryside and of the sea, the horizon). ${ }^{309}$ For Maine, \\ "the ius gentium 310 and the ius naturale were connected \\ by aequitas, which comes from the word aequus, which \\ connotes the sense of 'levelling.'"311
}

Falcón y Tella sees the first origins of aequitas in the ancient Greek Eikós, to which Aristotle curiously refers as "that which happens for the most part."312 Liddell and scott define Eikós more broadly around two primary meanings. On the one hand cikós is the probable, reasonable, likely, and close to the

308 Zepos, supra note 297 at 434.

309 María José Falcón y Tella, Equity and Law (Leiden: Martinus Nijhoff Publishers, 2008) at 23.

310 See Haines, supra note 253 at 10-11 ("Ulpian and other Roman jurists seemed vaguely to distinguish between the jus naturale and the jus gentium, the former partaking more of the primitive and instinctive rules applicable to all life, and the latter, of the conventional rules of mankind at a given time and place. Thus the later Roman jurists regarded slavery as contrary to the jus naturale, since men by the law of nature are born free and equal, but as sanctioned by the jus gentium. By the time of Justinian the jus naturale had come to mean a body of ideal principles which men could rationally apprehend and which included the perfect standards of right conduct and of justice. The compilers of the Institutes attempted to discriminate between the rules and instincts common to animals - the jus naturale; rules common to all mankind - the jus gentium; and the particular rules of a community - jus civile.") .

311 Maine, supra note 209 at 56.

312 Aristotle, Aristotle's Poetics, translated by stephen Halliwell (Chicago: University of Chicago Press, 1998) at 101. 
truth; on the other it is the fair and equitable. ${ }^{313}$

Falcón y Tella stresses that غ̇пı the idea of 'suitability'; while the term Aequitas carries with it the sense of 'rectitude'." ${ }^{314}$ Consequently, aequitas cannot be mapped directly on to غ́nıદíkદı $\alpha{ }^{315}$ Falcón y Tella takes the following view:

Etymologically, then, as its first meaning, "aequitas" seems to refer to equality, and in legal terms means that law has as an end the awarding of equal protection to equal interests and fellow beings who deserve it, in such a manner that the law must be the same for all individuals who make up society. The operation of justice is nothing but that of equalizing, of adjusting two things according to its rule of measuring with its ruler so as to identify one thing with another, by means of equitative or egalitarian proportion. ${ }^{316}$

The rendering of heterogeneous claims into a common horizon of assumed or systemically generated mutuality is a significant intrinsic shift from משיו ロי

Aequitas, as a justice claim associated with being treated on the same basis as others, is historically premised on becoming free from antinomical burdens rather than on assuming them. This has the consequence of putting unlike legal subjects on the same footing.

\footnotetext{
313 Note the circularity of the definitions when taken together.

314 Falcón y Tella, supra note 309 at 43.

315 Aequitas is also related to "the Sanskrit 'aika' (or 'aikya'; that is 'one'), and 'aikatuan' (unity, likeness), alluding to the idea of equality, equilibrium, proportion." see ibid at 23. 316 Ibid.
} 
Aequitas' contribution to equity, as we will when discussing the role of the Praetor Peregrinus, is to open the law to those who are outside or other to it. This is a process by which the legal subjects are emancipated from their alterity in order to be visible to law.

To the extent that this process enables agency, we can identify a dialectical relationship, analogous to that between positive and natural law. In Falcón y Tella's view:

It is commonly asserted that 'ius' tends to uphold the social order-and, hence, hierarchy, discipline-while 'aequitas' tends to embody social equality-that is, equality of treatment, the reconciliation of contrasting interests. ${ }^{317}$

The enabling of the subject through aequitas allows for a remedy, but at the expense of allowing the reification of ius. The justice alterity brought into ius conforms in large measure with an intrinsic rather than extrinsic trajectory, since aequitas aims at equality within the entirety of ius.

This last statement is not to be confused with the assertion that a just outcome cannot be produced through aequitas. The remedy offered through aequitas for a claim invisible to the quiritarian law was anal-

317 Ibid at $23-24$. 
ogous to the renunciations of right by the Talmudic

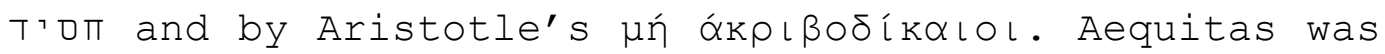
clearly better than no remedy at all.

At the same time, aequitas meant the shifting of alterity into law and the rendering of equity predominantly within the limits of the legal economy of affirmation. Even if other aspects of equity were later revitalized, this containment of equity within ius, along with the consequences it has for justice alterity and the emancipatory claim, remain with us today.

Although Cicero described aequitas as the spirit of the law in contrast to ius or the letter of the law, ${ }^{318}$ lawmakers in Roman times did not systematically use the term aequitas. ${ }^{319}$ Practical application of aequitas found its paradigmatic expression in the office of the Praetor Peregrinus, ${ }^{320}$ which came into ex-

\footnotetext{
318 Marcus Tullius Cicero, The Orations of Marcus Tullius Cicero (London: H.G. Bohn, 1856) at 65, cited in Zepos, supra note 297 at 434 .

319 This new body of law, which "had its source in the aequitas of the praetor", although he notes that "it does not seem that this body of law was ever itself called aequitas." See Sir John William Salmond, Salmond on Jurisprudence (Andover: Sweet \& Maxwell, 1957) at 87 .

320 The Praetor was preeminent Roman office equally applied to military command as to the judiciary. The Praetor "was a magistratus curulis, exercised imperium, and consequently was one of the magistratus majores. He had the right to sit in the sella curulis and wear the toga praetexta. [...] A praetor was a magistrate with imperium within his own sphere, subject only to the veto of the consuls (who outranked him)." See Barry Nicholas \& Ernest Metzger, An Introduction to Roman Law, revised ed (Oxford: Oxford University Press, 1975) at 4. See also Marcus Tullius Cicero, De
} 
istence contemporaneously with the implementation of the ius gentium, at the height of the Roman Republic. ${ }^{321}$

Rome's imperium produced the need to manage disputes among innumerably diverse peoples. ${ }^{322}$ The office of the Praetor Peregrinus (praetor qui inter peregrinos ius dicit), originally mandated for disputes between non-citizens, eventually became charged with disputes between citizens and non-citizens ${ }^{323}$ (praetor inter cives et peregrinos). As Maine summarizes:

In the early Roman republic the principle of the absolute exclusion of foreigners pervaded the Civil Law no less than the constitution. The alien or denizen could have no share in any institution supposed to be coeval with the state. He could not have the benefit of Quiritarian law. He could not be a party to the nexum which was at once the conveyance and the contract of the primitive Romans. He could not sue by the Sacramental Action, a mode

Re Publica: De legibus, translated by Clinton Walker Keyes (Cambridge, MA: Harvard University Press, 1961) at 467 ("Let there be two with the authority of the king, and let them be called praetors, judges and consuls from their going before, judging and consulting. Let them have the supreme right of command of the military $\left.[\ldots]^{\prime \prime}.\right)$.

321242 BC: Office of Praetor Peregrinus created. See A Arthur Schiller, Roman Law: Mechanisms of Development (The Hague: Mouton, 1978) at 403 .

322 See Rudolf Sohm, The Institutes: A Text-book of the History and System of Roman Private Law, translated by James Crawford Ledlie, 2d ed (Oxford: Clarendon Press, 1901) at 68 ("Numerous communities are annihilated by the Roman state; their members are incorporated with the Roman community without any treaty and without being placed on a footing or equality with Roman citizens ('dediticii'). The Roman civitas now becomes a valuable privilege. Even the mere jus commercii is only granted to noncitizens in exceptional cases, and the jus civile thus shuts its gates to the world without.").

323 Note that the Romans had a complicated system of legal statuses even as between cives. See ibid. 
of litigation of which the origin mounts up to the very infancy of civilization. [...] All ancient communities ran the risk of being overthrown by a very slight disturbance of equilibrium, and the mere instinct of self-preservation would force the Romans to devise some method of adjusting the rights and duties of foreigners, who might otherwise - and this was a danger of real importance in the ancient world - have decided their controversies by armed strife. ${ }^{324}$

Despite being elected officials (during the Republic), the Praetors had almost untrammeled judicial power, and were subject only to the right of the consuls. ${ }^{325}$

As Sohm notes:

For as against aliens he, the praetor, the magistrate of the city of Rome, was in nowise bound by the jus civile, nor even by popular statutes: popular statutes applied exclusively to citizens. As far therefore as the affairs of aliens were concerned the magistrate was absolutely unfettered in the exercise of his imperium. ${ }^{326}$

The body of law laid down by magistrates, the ius honorarium, was applied in the same court where ius gentium, ius naturalis ${ }^{327}$ and ius civile were also applied.

\footnotetext{
324 Maine, supra note 209 at 46.

325 They retained the Consul's ius militiae.

326 Sohm, supra note 322 at 69.

327 See Justinian, The Digest of Justinian (Philadelphia: University of Pennsylvania Press, 2011), glossary ("Ius Naturalis (Natural Law). A vague expression In Roman law. At times it was merely a synonym for the term Ius Gentium (q.v.]. It often means that the rule or principle in question was thought of as based on everyday experience, referred to as 'natural reason' [naturalis ratio]. Sometimes referred to as the justice or faintness of a rule, but the view of natural law as a universal ideal order in any way contrasted with positive law is almost entirely absent.").
} 
The praetors used their edicts to assist, complement, or modify the ius civile. Spence describes their interventions as follows:

To supply this deficiency in their original system of jurisprudence, first the consuls, then the Praetors, were permitted as occasion required to correct "the scrupulosity and mischievous subtlety of the Law," and supply its defects; not, indeed, as regards the Praetors, by altering the law itself, but by means of a distinct equitable code, framed by themselves and propounded on entering on their office; and which was for the most part administered by the same tribunals which dispensed the ordinary law, and by the same mode of procedure. ${ }^{328}$

Under the ius civile, foreign non-citizens could only rely on bona fides for the consummation of their rights. They had no standing to enter into or enjoy the protection of the law or the courts. By appealing to the Praetor Peregrinus non-citizens could achieve a remedy by virtue of praetorian edict.

The Roman praetors used their jurisdiction "to intervene on behalf of equity and against tradition."329

As Pomeroy stresses:

No separate tribunal or department was made necessary in the Roman jurisprudence, because the ordinary magistrates were willing to do what the early English common law judges utterly refused to perform - that is, to promote and control the entire legal development as the needs of an advancing

\footnotetext{
328 George Spence \& Henry Maddock, The Equitable Jurisdiction of the Court of Chancery (Charleston, SC: Nabu Press, 2011) at 322. 329 David Johnston, The Roman Law of Trusts (Oxford: Clarendon Press, 1988) at 4 .
} 
civilization demanded. ${ }^{330}$

In the course of time, "the flexible procedure of the peregrine praetor's court was made available for cases in which both parties were citizens."331

A Praetor Peregrinus's edict did not place a peregrinus in the same position as a Roman civis. In fact, Roman society was premised on categorization of its members according to the history of their integration into the empire. For example, the dediticii were members of conquered peoples whose individual political identity was considered extinguished. They were neither slaves, nor citizens, nor latini. ${ }^{332}$

The dediticii were in many matters devoid of legal agency. They could not have title in res nec mancipi because they were barred from offering a solemn mancipatio. ${ }^{333}$ Thus, the acceptance in the ius honorarium of

330 JN Pomeroy, A Treatise on Equity Jurisprudence, vol I, (San Francisco: AL Bancroft, 1881) at 9.

331 P Stein, "Equitable Principles in Roman Law" in René Cassin \& Ralph Abraham Newman, eds, Equity in the World's Legal Systems: A Comparative Study, dedicated to René Cassin (Brussels: Établissements Émile Bruylant, 1973) at 75.

332 Who enjoyed no rights of jus commercii or ius migrationis.

333 See Gaius, The Institutes of Gaius, translated by OF Robinson \& WM Gordon (London: Duckworth, 1988) at 81 ("Mancipatio is effected in the presence of not less than five witnesses, who must be Roman citizens and of the age of puberty, and also in the presence of another person of the same condition, who holds a pair of brazen scales and hence is called Libripens. The purchaser, taking hold of the thing, says: hunc ego hominem ex iure quiritium meum esse aio isque mihi emptus esto hoc aere aeneaque libra (I affirm that this slave is mine according to quiritary right, and he is purchased by me with this piece of bronze and scales). He 
a formless traditio ${ }^{334}$ to transfer title created a fundamental shift in Roman law; transfer of title became predicated on the fact that the purchaser paid the price and that there was clear expression of will by both parties. According to Sohm:

The principle thus adopted [...] was afterwards extended to traditio in general, provided only the parties had concluded some transaction which placed the intention to convey ownership beyond doubt. [...] For by securing the legal recognition of formless transactions, i.e. transactions which depend for their effect not on any form, not on something visible, external, or tangible, but rather on the will of the parties themselves, the jus gentium was laying down the lines of a new development for the law governing the ordinary dealings between Roman and Roman. ${ }^{335}$

Not only did the ius honorarium contribute to the general development of Roman law, it is also significant for an understanding of the dialectical development within the law of the relationship between otherregarding and justice alterity .

The Praetor Peregrinus was explicitly charged with

then strikes the scales with the piece of bronze, and gives it to the seller as a symbol of the price").

334 See Yves Congar, The Meaning of Tradition (San Francisco: Ignatius Press, 2004) at 9 ("[T] he Latin traditio, the noun of the verb tradere, 'to transmit', 'to deliver'. It was a term of ratification in Roman law: for example, the legal transfer of a shop or house was accompanied by the act of handing over its keys, tradition clavium; the sale of a piece of land was accompanied by the act of handing over a clod of earth. Tradere, traditio meant 'to hand over an object', with the intention, on the one hand, of parting with it, and, on the other, of acquiring it. Tradere implied giving over and surrendering something to someone, passing an object from the possession of the donor to the receiver."). 335 Sohm, supra note 322 at 70 . 
integrating the claims of those who had no legal agency and whose status precluded them from any expectation of such. In this sense, the emergence of the Praetor Peregrinus represents a watershed moment for the development of the fiduciary duty .

A petitioner had no legal right before the Praetor Peregrinus, who had to impute to the petitioner a justice outcome outside the existing ius civile. The adjudicated remedy did not convey to the petitioner the status of legal agency, nor did the remedy accrue to the individual, but rather to the consummation of ius aequum. The relationship taken up by a person with unfettered judgment to an entrustor, ${ }^{336}$ who was systemically barred from having formal rights, can be understood as a proto-fiduciary relationship.

In the example of the move from the solemn mancipatio to the traditio we can witness the assimilation of a justice alterity within the confines of a second order legal subjectivity. The extrinsic equitable claims of the peregrini (non-citizens) are introduced

${ }^{336}$ The general term used by Tamar Frankel for the beneficiary of a fiduciary duty across the spectrum of such obligations. According to Tamar Frankel the defining characteristics of fiduciary relations are (1) that "the fiduciary serves as a substitute for the 'entrustor' and (2) that the fiduciary obtains powers from the entrustor or from a third party for the sole purpose of enabling the fiduciary to act effectively." See Tamar Frankel, "Fiduciary Law" (1983) 71 Cal L Rev 795 at 808-809. 
to generate an extra-civic relationship to the quirites (citizens).

The basis of praetoria potestas aequitas is asserted when the performance of the prestation coupled with the expression of free will by both parties manifests an "equitable relationship." This relationship of virtual equality to that of legal subjects, predicated on factual circumstances and independent of the legal identities of the actors, allows aequitas to live up to its etymology. It performs a leveling function, producing equilibrium.

At the same time, this is predicated on the inflection of justice alterity into equality. ${ }^{337}$ That is, justice is served when the alterity of both parties is brought into a state of mirrored subjectivity. Ius aequum, though contrasted to ius strictum, nevertheless redirects equity's extrinsic tendency toward an intrinsic form.

Transcendent legal subjectivity becomes focused on establishing parity between concrete differences of social status and on investing in the concept of free

337 See Charles Howard McIlwain, The Growth of Political Thought in the West, from the Greeks to the end of the Middle Ages. (New York: Cooper Square Publishers, 1968) at 114-115 ("[T]he idea of the equality of men is the profoundest contribution of the stoics to political thought."). 
will. This focus casts a narrow light on justice alterity and significantly displaces the emancipatory claim. The mirrored subjectivities aligned through aequitas cannot give or receive the experience of justice alterity. Their imputed identity is predicated on abstracting from differences rather than on transforming or overcoming them. ${ }^{338}$

In this third example of the evolution of equity we witness a pivotal moment in the evolution of the legal person. The mirroring of Roman citizen and noncitizen was to be contained within the ius civile. Justice was to be the consummation of the selfunderstanding that equal treatment should ultimately obtain. This arose not by rejecting or overcoming distinctions of status, but in fact by conforming to the preconditions of legally designated identities, upon which aequitas would then operate.

Justice alterity was thus strictly speaking anomic and outside the Roman sense of self. Unlike the case of called upon to confront justice alterity by voluntari-

338 This is still seen today in the "objective standard" of contract formation in the common law where it does not matter what the actor's thought they were doing, rather what a reasonable legal person should have thought. See, Joseph M Perillo, "The Origins of the Objective Theory of Contract Formation and Interpretation" (2000) 69 Fordham L Rev 427. 
ly taking up a relationship to divine justice, or in

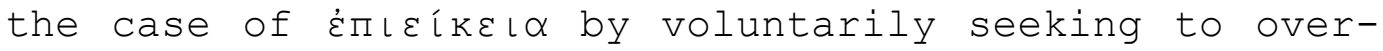
come the limitations of the law's purported universality, in the case of aequitas, actors are called upon to enter into a state of mutuality.

The aequitas of the Praetor Peregrinus emancipates the actors from the limitations of their subjectivity and enforces a relationship of mutuality. The Praetor must not mechanically apply the formal law, but rather must impute to the parties a mutually acknowledged normative space in which their equitable interests are present. Thus the praetor must take up a quasifiduciary role to the otherness of the parties' formal legal subjectivity.

The mirroring that this second order "non-legal" identity entails voids the agency of the actors towards justice alterity, reposing instead all such agency in the office of the Praetor. This voiding of legal subjectivity at the discretion of another charged with an outcome that is not self-interested and loyal to the second order subjectivity further underscores the proto-fiduciary moment.

Using the language of the justice matrix discussed in chapter one, the shift from ים משיו מרת הדלפנ to 


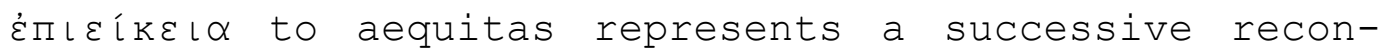
figuration of the matrix away from the metaphysical pole toward the conventional and subjective poles, with an attendant occlusion of the emancipatory pole.

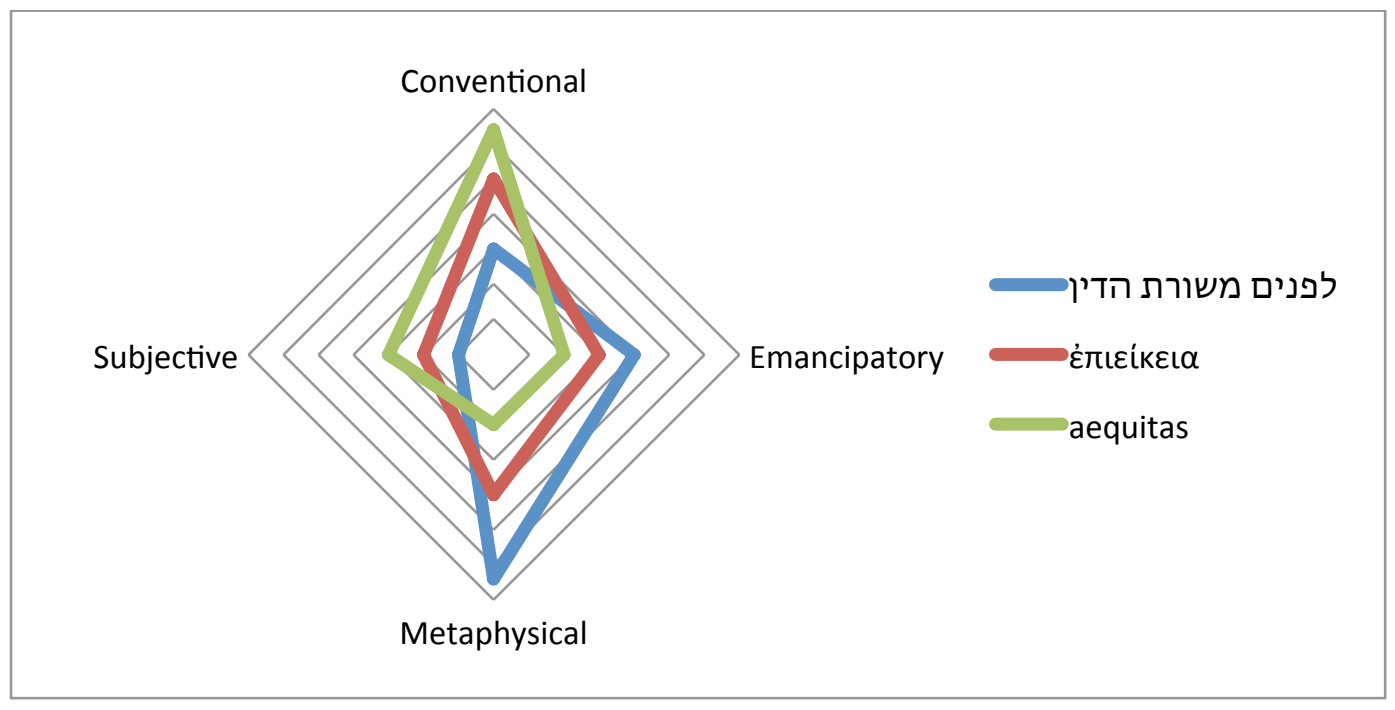

While the evolution of positive law at the conventional pole to embrace what previously was understood to be anomic was to be welcomed, this calls to mind the analogous configuration of emancipatory claims in legal positivism and natural law.

The assimilation of the emancipatory pole into the function of the Praetor foreshadows future authoritarian configurations of the justice matrix when an iteration of justice alterity is identified and affirmed as conventional at the expense of either the metaphysical or the subjective poles. In short, the affirma- 
tions of the peregrinus in aequitus ultimately legitimate the ius civiles, and the epistemic presumptions that it relies on.

In the last part of this chapter, I will continue the critique of how the second-order legal subjectivity became further internalized. English Equity, as reified conscience, marks yet another milestone of emancipatory inflection.

\section{Chancery}

The role of Chancery in English Equity was the culmination of historic developments surrounding English royal entitlement. As Sidney Smith writes, "Equity in the modern form, exercising a moderating influence in English law, was inherent in our 'jurisprudence' long before it became more specialized first by the King's Council, ${ }^{339}$ then by the Chancery and then by

339 See Spence \& Maddock, supra note 295 at 77 ("Besides the jurisdiction which was exercised by the king in his court, or by his councils, he appears to have exercised a kind of jurisdiction for mitigating the rigor of the positive law laid down in the codes, when its strict execution in the particular case, would have operated injustice. Thus, it is declared by the code of Edgar, that if the law were too heavy, a mitigation might be sought from the king. The law of Edgar [...] declared that it belonged to the king to solve ambiguities, and to interfere when a case arose requiring a remedy, but as to which the written law was silent; and to apply the doctrines of equity to the decision of cases involving special considerations. In each nation the prerogative appears to have been of imperial origin. Edgar's successors, Anglo-Saxon, Norman, and English, continued to exercise this jurisdiction, which is the germ of the jurisdiction of the court of Chancery. 
the Chancellor apart from the Council." 340

In the first period ${ }^{341}$ after the Norman Conquest ${ }^{342}$,

Adams describes Equity as

prerogative action, not yet distinguished from other prerogative action, [...] administered by [...] the Curia Regis, or by royal commissioners appointed for special cases, who hold a local Curia Regis. The action of the court is occasional only and by special permission. ${ }^{343}$

As Holdsworth comments:

It is quite clear that the jurisdiction exercised by the undifferentiated Curia Regis of the 12th century was marked by two of the chief characteristics which we associate with a court of equity. Proceedings were begun by a petition to the king for his interference; and that interference might result in remedies which, by reason both of their character and their methods of enforcement were, as Professor Adams has said, 'as much outside of, and in violation of, the ordinary system of justice which prevailed throughout the Anglo-Norman state, as ever Equity was at any later time in re-

To the king also, it belonged to protect persons in holy orders, and strangers who had no patron or defender.") .

340 Smith, supra note 257 at 311.

341 One account finds an explicit historical reference to the first English Chancellor during the reign of Edward the Confessor (1003-1066). See Frank Barlow, Edward the Confessor (New Haven: Yale University Press, 1997) at 245. Offices analogous to the Chancellor existed in a variety of forms before this, as in the case of the keeper of the seal during the Carolingian dynasty (750-887). See generally, Sidney Painter, A History of the Middle Ages: 284-1500 (New York: Knopf, 1956).

342 The office of the Chancery in England dates back at least to around the time of the Norman Conquest, and has been occupied ever since. See George Burton Adams, Council and Courts in AngloNorman England (New Haven: Yale University Press, 1926) at 202 ("There is no escape from the conclusion that institutionally the modern system of equity has come down to us in a continuous and unbroken growth from the system of prerogative action of the first Anglo-Norman kings, which was started upon a new development by the reforms of Henry II.").

343 George Burton Adams, "The Continuity of English Equity" (1917) 26:7 Yale LJ 550 at 554. 
lation to the Common Law systems.' ${ }^{344}$

It was only during the second stage of Equity (c. 1170

to c. 1300) that Royal courts were created,

to administer the prerogative interference with the ordinary procedure on equitable grounds. [...] Prerogative action was still the special function of the council and, by reason of that fact, the operation of these new courts was under the supervision of the Council, to which important and difficult cases were reserved. [...] The action of the council in this connection came soon to be known as coram rege and was the germ of the future King's Bench courts [...]. ${ }^{345}$

The court of Chancery ${ }^{346}$ itself dates to $1340 .{ }^{347}$ By the end of the fifteenth century the chancellor's court had become separate from the Council. ${ }^{348}$

The prerogative of English Equity departs more

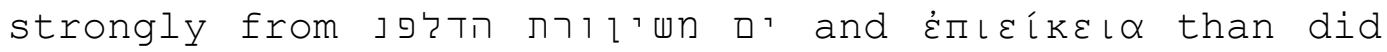
the aequitas of the Praetor. Even though the Praetor's "imperium" is comparable to the sovereign power of the Rex Anglorum, the Praetor (at least during the Republic) was obligated to exercise his power with a view to legal subjectivity rooted in the ius civiles, en-

\footnotetext{
344 Holdsworth, supra note 256 at 302 .

345 George Burton Adams, supra note 310 at 554.

346 See Adams, supra note 309 at 203 ("This equitable jurisdiction of the Council rapidly increased in importance during the fourteenth and fifteenth centuries, and somewhere in the fourteenth the chancellor began imperceptibly to relieve the council of some of this work, and so by degrees to draw off more and more of this equity jurisdiction until what we know as equity proper had been withdrawn from the Council.").

347 Holdsworth, meanwhile, indicates that Chancery was first mentioned as a court in 1340. See Holdsworth, supra note 256 at 67. 348 Ibid at 199 .
} 
hanced by other regimes discussed in the previous section.

\author{
English sovereign prerogative, ${ }^{349}$ despite the con- \\ tinuity of English law after the Norman invasion, 350 \\ was not bound by the same conceptualization of the le- \\ gal subject. ${ }^{351}$ It is within this context of heightened \\ prerogative, coupled with the unique representation of
}

349 See Blackstone, supra note 90 at 239 ("By the word prerogative we usually understand that special pre-eminence, which the king hath, over and above all other persons, and out of the ordinary course of the common law, in right of his regal dignity. It signifies, in it's etymology, (from prae and rogo) something that is required or demanded before, or in preference to, all others. And hence it follows, that it must be in it's nature singular and eccentrical; that it can only be applied to those rights and capacities which the king enjoys alone, in contradistinction to others, and not to those which he enjoys in common with any of his subjects: for if once any one prerogative of the crown could be held in common with the subject, it would cease to be prerogative any longer. And therefore Finch lays it down as maxim, that the prerogative is that law in case of the king, which is law in no case of the subject.").

350 See Hugh M Thomas, The Norman Conquest: England after William the Conqueror (Lanham: Rowman \& Littlefield Publishers, 2008) at 84 ("Because Anglo-Saxon law seems so different from the common law of England that began emerging in the twelfth century, it is easy to imagine that the Normans must have radically changed the legal system. The Normans themselves claimed otherwise. William I and his son Henry both promised to maintain the 'Law of Edward,' their name for the laws that were in practice when Edward the Confessor died. Sources from after the conquest reveal the Normans consulting with English experts on law. For instance, William himself had Aegelric, an aged bishop 'wise in the law of the land,' brought by wagon to testify in an important lawsuit between Archbishop Lanfranc and the king's half brother, Bishop Odo of Bayeux. Moreover, many Anglo-Saxon law codes were copied and studied after 1066, and a compilation describing the laws in practice under Henry I, containing much Anglo-Saxon law, was written by an anonymous French-speaking student of Anglo-Saxon law.").

351 After the conquest and the subjugation of the further rebellions, William held all lands. Subsequently, subjects enjoyed property rights at the King's pleasure. This was radically different from the Roman property law policies surrounding the ager publicus (public lands). See generally, JS Richardson, "The Ownership of Roman Land: Tiberius Gracchus and the Italians" (1980) 70 The Journal of Roman Studies 1 . 
a wide range of equitable doctrines, culminating in conscience, ${ }^{352}$ that we see the evolution of the fiduciary doctrine. Adams describes this progress as

directly in the line of the development of the equity system proper, which in the end passes under the jurisdiction of the chancellor [...]. [I]t falls within the function of the equity court to enforce the rules of reason and of conscience. This new doctrine assured a broader function than that of securing justice to all. It enabled the equity court to insist that faith should be kept in cases where the common-law courts could not act [...]. ${ }^{353}$

The shift in the locus of prerogative from the councils to chancery was the origin of an entirely new form of equity. Kerly notes that this enhanced adjudication allowed Chancellors to reach unconventional solutions:

The work of the Ecclesiastical Chancellors was an exceedingly beneficial one, for it may well be doubted whether judges trained in the practice of the Common Law would ever have possessed the courage to interfere with its rules, in the face of the professional opinion of their brethren, or indeed have been sufficiently detached in mind to discover that the rules stood in need of correction. It were better, the judges held, in the case of actions on bonds paid without acquaintance taken, that an individual should pay twice than that the law be changed, and it is certain that none but a great officer, wielding all the power of the King, could ever have enforced his decrees as the

352 According to Yale, in 1587 Sir Christopher Hatton became the first Chancellor to describe himself as the keeper of the royal conscience. See Yale, in Hake, supra note 254 at viii (preface). 353 George Burton Adams, supra note 343 at 559 [emphasis in original]. 
Chancellor did. ${ }^{354}$

As a court of conscience, the primary object of the Court of Chancery was not to "enforce or even primarily assist legal rights but [was] rather concerned to prevent their abuse." ${ }^{35}$ Chancery's untrammeled authority and focus on conscience produced an exceptional equitable relief based on a second order legal subjectivity, very different from that of aequitas.

The intrinsic and extrinsic aspects of equity experienced a paradigmatic transformation through the role of the Chancellor as keeper of the King's conscience. ${ }^{356}$ Smith asserted that "Chancellors supported by a recognition of conscience as a source of law, inaugurated the new stage in the development of English law." ${ }^{357}$ This conscience was to be the crystalline manifestation of natural and human law. The model outcome was to "purge the corrupt conscience of the defendant", not to redress the wrong done to the plain-

\footnotetext{
354 Duncan Mackenzie Kerly, An Historical Sketch of the Equitable Jurisdiction of the Court of Chancery (Cambridge, UK: University Press, 1890) at 94 .

355 Heneage Finch Nottingham \& DEC Yale, Lord Nottingham's Chancery Cases (London: B. Quaritch, 1957) at cvi-cvii.

356 See Rotman, supra note 263 at 199 ("In addition to being assigned jurisdiction over such matters because of his role as a cleric, the Chancellor became responsible for this task because he was also the highest official of the sovereign's council, and, most importantly, keeper of the sovereign's conscience.").

357 Smith, supra note 309 at 312 .
} 
tiff. ${ }^{358}$ That is, Equity was designed to bring the legal subject back into harmony with an overarching justice claim to which the King and the Chancellor were theoretically also bound.

Keeton and Sheridan make explicit the extent to which Chancery was obligated by justice alterity:

In the Chancery a man shall not be prejudiced by mispleading or by defects of form, but he shall be judged according to the truth of his case; and we must judge according to conscience and not according to things alleged by the parties. And there are two manner of powers and processes in the Chancery - the Ordinary and the Absolute power. The Ordinary power is the power in which a certain order is observed just as it is observed in positive law; but the law of nature has no certain order, but it acts by any means that the truth may be known, and therefore is its procedure called Absolute. 359

The Chancellor was originally an ecclesiastic ${ }^{360}$ versed

in Roman $^{361}$ and Canon law. ${ }^{362}$ His position as an eccle-

358 As Ashburner points out, "[i]n spite of its different focus than the common law, Chancery's cleansing of a wrongdoer's conscience did generally carry the ancillary effect of redressing wrongs perpetrated against the complainants." See Walter Ashburner, Principles of Equity (Oxford: Butterworth \& Co., 1902) at 38. 359 George Williams Keeton \& LA Sheridan, Equity, 3d ed (Chichester, West Sussex: Barry Rose, 1987) at 3.

360 Being one of the few literate in the realm, he was keeper of the royal seal and documents.

361 As Newman indicates, "from 1330 to 1515 at least 15 chancellors had studied either canon or Roman law." See Newman, supra note 80 at 27 .

362 See Charles George Herbermann, The Catholic Encyclopedia: an international work of reference on the constitution, doctrine, discipline, and history of the Catholic Church (New York: Encyclopedia Press, 1913) at 57 ("[J]us canonicum becomes current only about the beginning of the twelfth century, being used in contrast with the 'civil law' (jus civile), and later we have the 'Corpus juris canonici', as we have the 'Corpus juris Civilis'. Canon law is also called 'ecclesiastical law' (jus ecclesiasti- 
siastic befitted his ability to provide advice or render opinions on matters of grace and charity. Early Chancellors were not even necessarily familiar with the common law. ${ }^{363}$

The Chancellor could exceed the limits of the common law to "unburden the conscience of the defendant," but this also led to widespread discontent over the unpredictability and certainty of outcomes. ${ }^{364}$ As Holdsworth comments, "[i]t is clear that in early days there were no fixed principles upon which the Chancellors exercised their equitable jurisdiction."365 Norburie, writing in the middle of the seventeenth century, noted that

the boundless power of the Chancery in not having rules and grounds written and prescribed unto it, in what cases it shall give relief and in what not, is the cause of much discontent and distraction to the King's subjects, and clamours against

cum)."). Canon Law draws its influences from the Old and New Testaments, as well as Roman, Saxon, and Celtic legal sources. See generally, Robert Cecil Mortimer, Western Canon Law (Berkeley: University of California Press, 1953).

363 As Kerly notes, "[t] he Chancery was naturally identified with the Church, since, with few exceptions [...]The Chancellors were always Churchmen, and generally Archbishops and Cardinals, until the appointment of Sir Thomas More by Henry VIII." See Kerly, supra note 354 at 44 .

364 See Sir William Searle Holdsworth \& John McDonald Burke, A History of English Law: The Judicial System (London: Methuen, 1956) at 451 ("The Chancellor, putting the case of an official privileged to be sued only in the chancery, said that he might use either his legal or his equitable jurisdiction: 'for if it appear upon the matter showed in the suit that there is conscience, he may judge thereof according to conscience'.") .

365 Ibid at 467 . 
the Lord Chancellor. ${ }^{366}$

Keane points out that,

it is also worth noting that the clerics who staffed the medieval Chancery, unlike the judges of the courts of common law, were not dependent upon the jury to supply it with the factual basis for the decision of a case. Until the time of Francis Bacon, ${ }^{367}$ Chancery followed a practice of examining witnesses to inform the conscience of the court. This practice may have derived from continental procedures: that would hardly be surprising because in both cases procedures of the confessional were part of their professional lives: resort to examination of the parties in order to get at the truth of a dispute and to reconcile them with the conscience of the court did not involve a creative leap. ${ }^{368}$

The significance of the role of conscience cannot be

overestimated. The justice imaginary thus advanced was significantly different from that of the common law.

Keane writes:

The mindset of the late medieval and early modern clerics who established equity's mission was formed within an intellectual tradition, articulated most authoritatively by Thomas Aquinas, ${ }^{369}$ which accorded primacy to the idea of the person as opposed to the individual. Within this tradition the emphasis was upon the community as a society of persons in relationship with each other and, of course, with God, rather than a multitude

366 See generally, Francis Hargrave et al, The Abuses and Remedies of Chancery (Abingdon, Oxon: Professional Books, 1982).

367 Bacon was Chancellor from 1618-1621.

368 PA Keane, "The 2009 Wa Lee Lecture in Equity: The Conscience of Equity" (2010) 10:1 Law and Justice Journal 106 at 111.

369 See St Thomas Aquinas, Summa Theologica, translated by Fathers of the English Dominican Province (New York: Cosimo, 2007) at 995

("Thus from the four preceding articles, the definition of law may be gathered; and it is nothing else than an ordinance of reason for the common good, made by him who has care of the community, and promulgated.") . 
of atoms bound together only by prudent bargains struck at arm's length. This tradition was concerned with the social responsibilities of individuals, not their rights. ${ }^{370}$

Aquinas summarized law as being "nothing else than an ordinance of reason for the common good, made by him who has care of the community, and promulgated."371

Without reason, acts could not be freely willed. They would be simple reactions or instincts, with no necessary ethical claim. The criterion of common good is equally central. Something can only take on the characteristic of normative value if it produces benefits for more than just the person proposing it.

Thus, the Thomist influence on the Chancellor privileged legal subjectivity that fully affirmed the role of reason, albeit reason of divine provenance, while at the same time mandating that the object of such reason be the generation of collective value. The legitimate subjectivity that the Chancellor imputed to

370 Keane goes on to emphasize that Aquinas primarily drew on Aris-

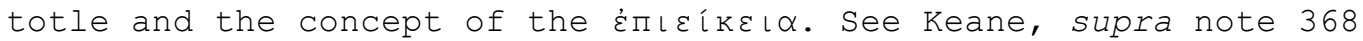
at 4 .

371 Aquinas, supra note 369 at 1820. Aquinas also makes distinctions between eternal law, natural law, and human law. Eternal law is divine timeless reason that moves providence, available to us by revelation, and the only source of justice alterity that can overcome human limitations. Natural law is the manifestation of eternal law in the reason and rational acts of humans. Natural law consists of five virtuous inclinations: embracing the good, conserving of life, conserving the species, propagating life, discovering the truth, and sustaining the life of society. Reason enables us to articulate the meanings of these inclinations through our thoughts and actions. Human law is the perfection of virtue in the particular case. 
the conscience of the litigants was sui generis and without possible contradiction. The seat of obligation was no longer to be found in the "legal rights" of an individual (or citizen), but rather the ability of that actor to reveal reason compatible with the common good.

Whereas in the previous forms of equity that we have explored, the litigants were recognized in their otherness to the law, from a Thomist perspective, this otherness was no longer normatively constitutive. ${ }^{372}$ Rather, the relevant otherness was to be found in the legal subject, whose own conscience produced an alterity to the legal outcome insisted upon at common law.

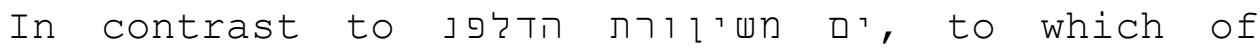
course the Thomist notion of conscience was related, the key moment is the inner alignment of self with good conscience rather than the foregoing of right so as to fulfill a higher external justice. ${ }^{373}$ This align-

\footnotetext{
372 See Edmund Henry Turner Snell, Snell's Equity (Andover: Sweet \& Maxwell, 2005) at 93 ("This imputation of conscience to the actors also had the consequence that their legal actions would themselves have to issue from such a 'conscience'. From whence comes the admontion that ' $[\mathrm{h}] \mathrm{e}$ who comes into equity must come with clean hands." ") .

373 On the inward turn of selfhood, see generally, Charles Taylor, Sources of the Self: The Making of the Modern Identity (Cambridge, MA: Harvard University Press, 1992). On the relationship between conscience and "synderesis," an inner spark of God, see Richard Janda, "Equity, Legal Architecture, and Christopher st. German" in Brierley et al \& Centre de recherche en droit privé et
} 
ment had to be enabled by another, personified by the Chancellor.

The extent to which the chancellor could take up an enabling relationship to inarticulate legal subjectivity can is demonstrated in an example cited by Vinogradoff. In a case where the defense was raised that the plaintiff had been negligent in adherence to the rules regarding covenants, the Chancellor Bishop Stillington granted a motion based on the following argument:

God acts as attorney to foolish people. ${ }^{374}$ The maxim bears the stamp of rough and ready mediaeval clericalism, and it opened the way for the chancery to look behind the external regularity of all sorts of transactions with a view to the redress of wrongs committed by skilful miscreants who had taken advantage of weakness of intellect, insufficient knowledge, or casual negligence. ${ }^{375}$

comparé du Québec, eds, Mélanges Paul André Crépeau (Cowansville: Éditions Blais, 1997).

374 As Klinck points out, this maxim has an ambivalent provenance. Y BP 8 Edw IV Pf4, pl 11 contains the expression, "[d]eus est procurator futurorum, meaning that God looks after the departed, 'and the Chancellor, being charged to God's will, must act appropriately and make sure that the will is performed for the good of the soul of the departed'." Roben Stillington (1420-91), Bishop of Bath and Wells and Chancellor from 1467-70, is reported to have used the formulation deus est procurator futurus [...]. More commonly this is read Deus est procuraton fatuorum and is taken to mean that God, not the court, looks after fools, that is, the court will not give relief for injuries arising from the plaintiff's own folly." See Dennis R Klinck, Conscience, Equity and the Court of Chancery in Early Modern England (Farnham, Surrey: Ashgate, 2010) at 23 .

375 Y BP 8 Edw IV Pf4, pl 11, cited in Sir Paul Vinogradoff, The Collected Papers of Paul Vinogradoff: Jurisprudence (Oxford:

Clarendon Press, 1928) at 199. 
The role of "conscience" in Chancery was thus to enable those incapable of affirming their own subjectivity. In this way it became a critical factor in the development of the fiduciary relationship.

In Chancery, justice was understood as rendered through conscience, namely an alterity to anything alien to "reason" (not the same thing as reason itself, since divine reason is not fully accessible), and subject to the test of transcendent eudaemonic affirmation. The eudaemonic moment predicated itself on the renunciation of subjectivity for all participants. Absolute prerogative prevailed in Chancery's jurisdiction provided these conditions were met, and produced a second order subjectivity personified in the chancellor.

This second order subjectivity had implications that went far beyond the concept of equality in the Praetor's ius honorarium, which was not lost on those affected. A sixteenth century commentator, William Lambarde wrote:

For seeing that the Positive and Common Law is made meet for the most part, and that Equitie is added for helpe in some few or singular cases, it followeth by reason, that commonly and regularly the positive Law should bee put in ure, and that Equitie should not bee appealed unto but only in rare and extraordinary matters, lest on the one 
side, if the judge in Equitie should take Jurisdiction over all, it should come to pass (as Aristotle saith) that a Beast should beare the rule: For so hee calleth man, whose judgement, if it bee not restrained by the Chaine of Law, is commonly carried away, with unruly affections. And on the other side, if onely streight Law should bee administred, the helpe of GOD which speaketh in that Oracle of Equitie, should be denyed unto men that need it. And therefore even as two Herbes being in extremitie of heat, or cold, bee by themselves so many poysons, and if they bee skilfully contempered, will make a wholesome Medicine $[. ..] .{ }^{376}$

The beast here is the risk of totalizing the emancipatory claim understood as "reason" qua the true expression of conscience. ${ }^{377}$

In Chancery, the inflection produced by the affirmation of "reason," at the expense of other forms of justice, radically internalized the emancipatory claim. Other-regarding was only affirmed to the extent that it was in conformity with such "reason." The individual was always in a position of inadequacy vis-àvis this outcome.

The conscience of Chancery produced an historic internalization of justice alterity into the core conceptualization of (legal) subjectivity. This opened up the justice imaginary to a previously unknown concept of other-regarding. The "absolute" power in Chancery -

376 Lambarde, supra note 256 at 44.

377 This is a paradigmatic example of the inter-dependence between episteme and justice imaginary. 
its crystallization of prerogative and justice alterity - is the core of fiduciarian other-regarding. Chancery would not have reached the fiduciarian threshold but for the specific form of prerogative it embraced. The antinomy between just power wielded for the other, and the inadequacy of any legal subject to wield such power, animated the Equity pursued in Chancery and, as we will see in the next chapter, became the antinomical burden borne by the fiduciary relationship.

One might, in summary, depict the shift in the justice matrix effected through the English Equity as follows (maintaining the comparison with classical equity) :

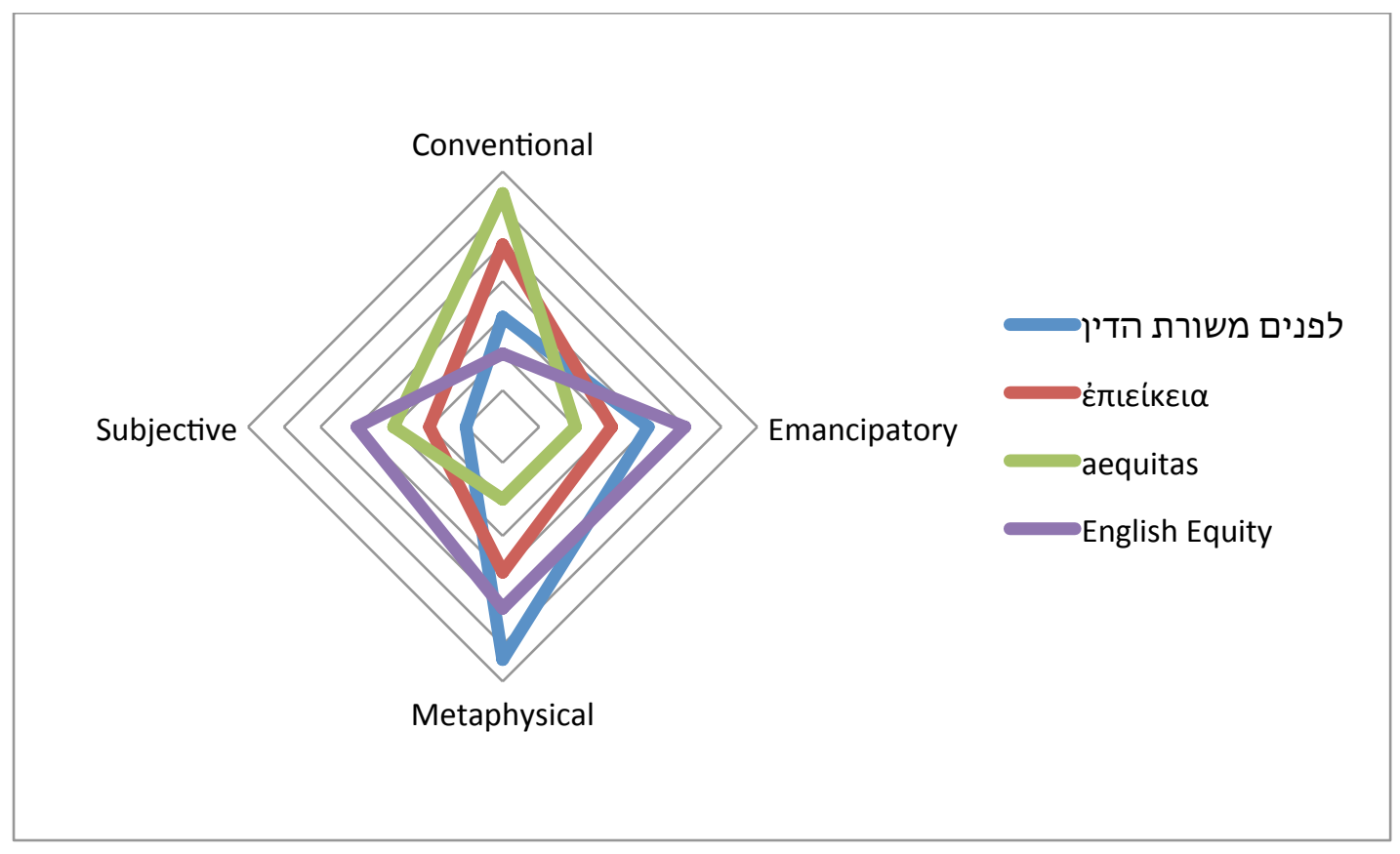


The Chancellor's prerogative appeal to conscience "flattened" the predominance of the conventional pole characteristic of aequitas and even as compared with the significance of halakhah in Jewish law. It maintained the significance of the metaphysical pole, although placing it further out of reach than through .ים משין Bיורת הדלפנ But its most significant contribution was to strength the subjective and emancipatory poles, albeit in an antinomical relationship. The next chapter will pursue a further elaboration of these themes. 


\title{
Chapter 4: Fiduciary Relations and Antinomical Burdens
}

\author{
As we saw in chapter two, positive law's legitima- \\ cy depends on an identification with empirically de- \\ terminable norms capable of generalization. Natural \\ law depended on threshold moments of normative affir- \\ mation that contain unavoidable epistemic limitations. \\ By contrast, every stage of equity explored in chapter \\ three involves a negotiation of heterogeneous claims.
} Equity also takes on the conflict between the law and those claims that are also relevant to a just outcome, but do not or cannot conform to the law. It acknowledges the problem of rendering justice based on multiple (mutually exclusive) justice claims. In this sense, equity does not simply correct the law's imperfections. ${ }^{378}$

Equity must adjudicate such that the normatively "legal" (i.e. what is within the horizon of expectations of legal subjectivity) persists, while at the same time assuming responsibility for its own ambivalence in relation to legal outcomes. Equity cannot be legitimate ${ }^{379}$ without also producing a shift in legal

\footnotetext{
378 This can be seen as the effect of equity, but not necessarily its cause.

379 Here understood as "conformable to law or rule; sanctioned or authorized by law or right; lawful; proper". See OED, supra note 15 .
} 
subjectivity such that this subjectivity itself becomes identified with the balancing of justice antinomies. In this sense equity is by definition the internalization of antinomical burdens and is a (negative) affirmation of justice alterity. ${ }^{380}$

This chapter seeks to explore how equity engages with legal subjectivity through the fiduciary relationship. Its structure departs somewhat from that of the previous two chapters, each of which sought to canvass a range of examples illustrating shifts in the configuration of the justice matrix, notably in relation to emancipatory claims.

In this chapter, the focus is on how equity can produce a legal subjectivity that both bears existing antinomical burdens and enables future legal subjectivities that are emancipated from existing unavoidable justice affirmations. The following chapter will bring the theoretical analysis to bear on contemporary judicial decisions concerning the fiduciary relationship.

This chapter begins by confronting law's continuous inadequacy to render justice. This is followed by

380 For an attempt to map out justice alterity in natural law and positivism, see Richard Janda, "Law's Limits" (1989) 63 S Cal L Rev 727. 
an account of the epistemology requisite to enabling emancipatory claims (drawing here explicitly on the work of Theodor Adornol. This emancipatory epistemology is contextualized and set into relief through a discussion of Hegel's parallel epistemological project: his dialectics. Returning to Adorno then allows a clearer insight into what is meant by negative dialectics.

With these epistemological foundations in place, the thesis investigates non-identity and the constitution of the subject. It then turns to how this relates to the problem of disappointment ${ }^{/ 1}$ as well as to the economy of affirmation, both identified in chapter one. The question then becomes how the antinomically burdened and fragmented subject, who is located within an economy of affirmation that produces unavoidable limitations upon recognizable justice claims, can relate to justice alterity - to a utopia that is at once a non-place and a summum bonum.

Adorno's analysis allows for a non-affirmative approach to the justice reserve available within the existing economy of affirmation and its attendant legacy subjectivity, and thus for the modeling of a fiduciary relationship to justice alterity. 
Nevertheless, Adorno's negative dialectics produce what I characterize as a defective emancipatory algodicy (legitimation of pain), borrowing a term from Peter Sloterdijk. ${ }^{381}$ Fully acknowledged fiduciary relations would alter or sublate suffering rather then merely bearing it.

\title{
Continuous Inadequacy
}

\begin{abstract}
Macro-normative evolution means a continuous process of integrating and resourcing a confrontation with law's failure and persistence. This type of antinomical task is already fully present as an ethos in equity. Yet, equity's co-dependency with law limits its capacity ex ante to question law's hegemony. Whereas equity engages antinomical burdens apposite to law, the fiduciary relationship is premised on law's failing.
\end{abstract}

Legal relations affirm some form of equivalence; a mirroring designed to reproduce the mutuality of expectations. In equity, the differences between legal actors are engaged in order to be bridged by equitable adjudication. By contrast both to law and equity, in fiduciary relationships no equivalence or mediation is

381 Sloterdijk, supra note 59 at 460 . 
sought. Fiduciary relationships iterate a form of justice predicated on the persistence of the incommensurability of roles. The fiduciary relationship relies on legal subjectivities and systematically disables them. ${ }^{382}$ Clark writes that,

[f]iduciary law is stricter on fiduciaries than contract law is on ordinary contracting parties in at least four fundamental respects. There are stricter rules about disclosure, more open-ended duties to act, tighter delineations of rights to compensation and to benefits that could flow from one's position, and more intrusive normative rhetoric. ${ }^{383}$

Posner J. observed that "contract law does not require parties to behave altruistically toward each other; it does not proceed on the philosophy that I am my brother's keeper. That philosophy may animate the law of fiduciary obligations but parties to a contract are

\footnotetext{
382 For example, contract law looks at the actions of both parties; where fiduciary duties apply only the fiduciary's actions are relevant. Despite being decidedly opposed to seeing fiduciary duties as anything other than a method of lowering transaction costs by decreasing the need for defensive behavior. Even Easterbrook \& Fischel cite Market Street Associates Limited Partnership $\checkmark$ Frey to acknowledge that "[t]his duty [of good faith in carrying out a contract] is, as it were, halfway between a fiduciary duty (the duty of utmost good faith) and the duty merely to refrain from active fraud. Despite its moralistic overtones it is no more the injection of moral principles into contract law than the fiduciary concept itself is." See Market Street Associates Limited Partnership V Frey H (1993), 21 F3d 1993 782, online <http://openjurist.org/21/f3d/782/market-street-associateslimited-partnership-v-frey-h> .

${ }^{383}$ RC Clark, "Agency Costs Versus Fiduciary Duties" in JW Pratt \& RJ Zeckhauser, eds, Principals and Agents: The Structure of Business, (Boston: Harvard Business School Press, 1985) at 76.
} 
not each other's fiduciaries [...]."384 David Hayton adds that "ultimately, fiduciary relationships are imposed $^{385}$ by equity, not by agreement of the parties." ${ }^{386}$ Fiduciary duties require adequate real time resources around a risk that remains potentially indeterminate. The fiduciary and the beneficiary are in a relationship where a single self-regarding action can negate it in its entirety. The fiduciary relationship is at the risk of the moment. It is not even relevant to a fiduciary breach what a fiduciary believed he or she was doing, or even what benefit was intended for the beneficiary. The nature, scope, and duration of the duties in question are exceptional.

Given that the fiduciary's judgment will be prone to error, and that the best outcome for the beneficiary is subject to interpretation, entering the fiduciary relationship is fraught with more potential lia-

384 Original Great American Chocolate Chip Cookie Company Incorporated V River Valley Cookies Limited M Sigel (1969), F2d 1969

273, online <http://openjurist.org/970/f2d/273/original-v-river> at 22 .

385 The absence of an undertaking by the fiduciary is no bar to liability. See Deborah A DeMott, "Fiduciary Obligation under Intellectual Siege: Contemporary Challenges to the Duty to be Loyal" (1992) 30 Osgoode Hall LJ 471 at 475.

386 David Hayton, "Fiduciaries in Context: An Overview" in Peter Birks, ed, Privacy and Loyalty (New York: Oxford University Press, USA, 1997) 284 at 284. 
bility than taking up any other legal relationship. ${ }^{387}$

Once fiduciary duties are established, it is difficult to conclude that they have been irrevocably extinguished. ${ }^{388}$ In this sense the participants in a fiduciary relationship are always inadequate to its potential scope. Even if a fiduciary comports him or herself within known boundaries of accountability, a court may determine that a higher standard was required in the circumstances. This has considerable implications for our relationship to, and conceptualization of legal subjectivity.

The contours of fiduciary obligations hover around the moral precipice of uberrima fides. No amount of effort will permit us to know with certainty that we have fulfilled this criterion: "[n] ot honesty alone, but the punctilio of an honor the most sensitive, is then the standard of behavior". ${ }^{389}$ One is a fiduciary because one stands in a certain relationship to the other, not because the title of fiduciary has

387 Marsman v Nasca (1991), 5731991 NE 2d 1025. In this case, an attorney incurred liability for having inadequately inquired into the financial needs of the beneficiary.

${ }_{388}$ Cf Stewart V Canadian Broadcasting Corp, (1997) 150 DLR (4th) 24 (ONSC). 10 years after defending a client, Edward Greenspan participated in a television dramatization of events related to the accused. Greenspan was held liable for breach of his fiduciary duties that were created during the period of his representation, even though the court found that he had no present fiduciary duties to his former client.

${ }^{389}$ Cardozo CJ in Meinhard V Salmon, 164 NE 545 at 464. 
been bestowed.

Fiduciary obligations focus on the relationship

between the parties, and circumstances that surround the fiduciary's exercise of discretion. The desire of the fiduciary to engage in behaviour that deviates from the abstraction of "most abundant faith", even if the beneficiary agrees, is pursued at the fiduciary's own risk.

The fiduciary's position of power produces a moral hazard: the ease of and opportunity for misappropriation. To remedy breaches of fiduciary discretion, far-reaching powers are necessary. Fiduciary obligations do not typically allow for anything comparable to liquidated damages, and do not stop at restitutio in integrum.

Laura Hoyano's provisional list of potential fiduciary liabilities underscores their overwhelming consequences. They include:

Circumventing common law barriers to establishing liability, such as negating apparent consent to a battery, or defeating any exclusion of liability or liquidated damages in a contract between the parties; overcoming procedural hurdles, such as avoiding limitation periods applicable to common law actions [...]; Establishing a breach of duty where the evidence falls short of proof of the subjective dishonesty required for deceit, or of breach of a common law standard of care, through the construction of evidential presumptions and 
shifting the burden of proof of certain exculpatory facts to the fiduciary; Surmounting other evidential problems, such as proof of harm to the plaintiff, and forging a causal link between that loss and the defendant's breach of duty; and seeking to hold a fiduciary responsible for losses caused by events and parties beyond the fiduciary's control. 390

Breach of fiduciary duties enables an entirely different regime of remedies:

[...] greater quantum of monetary compensation by sweeping all losses, including those in excess of the compensatory measure, into the consequences of the breach of duty, by dispensing with the common law limitations of foreseeability and remoteness of loss; by seeking to avoid the mitigation principle operating against the plaintiff in common law wrongs; by avoiding reduction of damages for any contribution to the breach or loss by the plaintiff; by obtaining exemplary damages. Finally breach can also attract "proprietary remedies", such as equitable tracing of the plaintiff's property into hands of subsequent transferees (other than a bona fide purchaser without notice) or into substituted property, or creation of a constructive trust. ${ }^{391}$

The scope of fiduciary consequences serves two clear purposes: to deter and to remedy. ${ }^{392}$ In both cases, its reach is unparalleled. Only the consciousness of the fiduciary's inadequacy to the totality of all possible

390 LCH Hoyano, "The Flight to the Fiduciary Haven" in Peter Birks, ed, Privacy and Loyalty (New York: Oxford University Press, USA, 1997) at 175-77 (references omitted).

391 Ibid.

392 "The rule, inveterate and uncompromising in its rigidity, does not rest upon the narrow ground of injury or damage [...] resulting from a betrayal of confidence, but upon a broader foundation of a wise public policy that, for the purpose of removing all temptation, extinguishes all possibility of profit flowing from a breach of the confidence imposed by the fiduciary relation." Guth $\checkmark$ Loft Inc, 5 A 2 d 503 at 510 . 
outcomes allows for the fiduciary relationship to be legitimately engaged. The fiduciary relationship is the paradigmatic case for the continuous resourcing of justice alterity and indeterminacy.

\section{Adorno's Emancipatory Epistemology}

In order to probe the conceptual foundations of the fiduciary relationship, I turn to the work of Theodor Adorno, because his Negative Dialectics (hereafter ND) is focused on mapping the relationship between antinomical negotiation, epistemology, and justice.

The previous chapters have explored how alterity relates dialectically to an understanding of justice. Here I will seek to show that fiduciary indeterminacy is graspable using negative dialectic modeling. Negative dialectics helps to make the justice claims and tensions contained within the fiduciary relationship more epistemically and normatively transparent. Accordingly, Adorno's critique may help to reveal sustainable yet radical emancipatory characteristics in the concept of fiduciary obligations.

The opacity ${ }^{393}$ of Adorno's style is methodological-

393 See Theodor W Adorno, Negative Dialectics, translated by Dennis Redmond at 63 [unpublished] ("The almost universal compulsion to confuse the communication of that which is cognized with this 
ly linked to his deep aversion to the concepts of synthesis ${ }^{394}$ and affirmation. His resolute assertion was that any purported philosophy that can be taught is not in fact philosophy. ${ }^{395}$ To write about the ND means essentially to engage in exegesis. Axel Honneth and Christoph Menke point out that attempts to render Adorno's work outside of its own constellational form are problematic:

The minute the attempt is made to render a part of the argument outside of the organic compositional whole, one loses not only the character of expression, but also a not trivial amount of substance; and in the alternative any attempt to assume the voice or style of the text in order to do it justice, ends in superficial paraphrase. ${ }^{396}$

Yet, it was not Adorno's intention to leave his work unread or unreadable. His objective was to produce an experience with the reader that would in some way already be a trace of the enabling that transformed subjectivity would have required.

Adorno's thinking is structured as constellations of concepts meant to be grasped interdependently. He

former, all too often ranking the latter as higher, is to be resisted; while at present, every step towards communication sells truth out and falsifies it.").

394 Theodor W Adorno, Lectures on Negative Dialectics: Fragments of a Lecture Course 1965/1966, translated by Rodney Livingstone (Cambridge, MA: Polity, 2008) at 16.

395 Adorno, supra note 393 at 19 ND.

${ }^{396}$ Christoph Menke \& Axel Honneth, Theodor W. Adorno: Negative Dialektik (Berlin: Akademie Verlag, 2006) at 11 [translated by author]. 
does not argue in a linear fashion. Towards this end Adorno sets antinomical conceptualizations in a compositional whole. They contain not only the consciousness of their contingency, but also the awareness of our need to project affirmations on to them. ${ }^{397}$

If, as asserted in the Dialectic of Enlightenment, ${ }^{398}$ the mythical character of conceptual ordering is inescapable, and a conscious return to myth is itself an equally illegitimate regression, then the alternative that Adorno embraces is to produce a composition of opposing conceptual and non-conceptual elements - animi if you will - which are in turn refracted through their self-consciously aesthetic deployment.

The ethical moment in Adorno's approach arises from the fact that nothing can be taken for granted. Adorno has accepted that conceptual thought is always already totalitarian, but inexorable. The confrontation with conceptual thought produces the need to hover in proximity to it, so as not to let mythical aspects of irrational thought assert themselves un-

\footnotetext{
397 See generally, Richard Lehun, "Affirmation und Schein" in Gisela Engel \& Gisela Notz, eds, Sinneslust und Sinneswandel: Beiträge zu einer Geschichte der Sinnlichkeit (Berlin: Trafo, 2001 ).

398 Horkheimer \& Adorno, supra note 28.
} 
checked, but at the same time never to draw or directly rely upon it. ${ }^{399}$

In this sense, his negative dialectic is a methodological response to the disappointment ${ }^{0 / 1}$ problematic and emancipatory implosion. It seeks to relate to the conceptual affirmations of legacy subjectivity without either embracing them or cutting them loose.

Two intertwined leitmotifs govern Adorno's approach. On the one hand, it is characterized by a deep commitment to exploring the question of emancipatory justice; that is, how might we approach an aggregate justice that substantively transcends the limitations of the given? Negative Dialectics seeks through critical exploration of what is immanent in the given to work through the given towards this end. At the same time, transcending the given means coming into proximity with an alterity that cannot be localized in it. An understanding of the ND is dependent on the reader's capacity to bear this tension.

For Adorno, critique is concerned with the nonidentity of a phenomenon with its conceptualization. Hence, for me, critique is also concerned with the

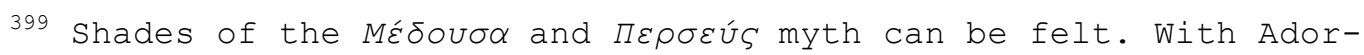
no's opacity related to the ä̈ठos kuvénv. See Homer, The First Six Books of Homer's Iliad, translated by Charles Anthon (New York: Harper, 1876) at 381 . 
non-identity of myself as phenomenon with what I apprehend conceptually. This latter dimension of critique is explicitly framed by Adorno as relating to justice: "These [two aspects of a phenomenon] are measured here against the yardstick of their concept because their non-identity with themselves, which they always claim they possess, also tells us something about their rightness or wrongness." 400

His justice theory of the concept impacts on the legitimacy of a phenomenon; that is, since the phenomenon and its concept are non-identical, the dissonance between the two produces zones of illegitimacy for the phenomenon. Adorno asserts, in a mirrored turn, that the phenomenon is subject to an immanent critique originating in its conceptual substrate. Not only is the concept subject to critique for its non-identity with the phenomenon, but the phenomenon is also subject to critique for its non-identity with the concept as it relates to questions of justice. It is only in this sense that Adorno perceives philosophy as legitimate. ${ }^{401}$ In this double turn Adorno asserts an unreal-

400 Adorno, supra note 394 at 40.

401 See Adorno, supra note 361 at 47 ("In the unreconciled condition, non-identity is experienced as that which is negative. The subject shrinks away from this, back onto itself and the fullness of its modes of reaction. Only critical self-reflection protects 
ized justice potential.

I have linked the consciousness of inadequacy at the core of the fiduciary relationship to antinomical burdening and justice alterity. The fiduciary relationship is legally binding and is held up to the highest standards of other-regarding behaviour by negating the "legal" subjectivity of both the fiduciary and the beneficiary.

The fiduciary relationship thus anchors incommensurability within the law. Exceptionally, this incommensurability extends into forms of justice that are not capable of being identified either in advance, or even at the moment that they become material. Contemporaneous with the embrace of antinomical burdens, fiduciary relationships thus also incorporate forms of justice indeterminacy.

Whereas justice alterity reflects the impossibility of closing the canon of what may be an iteration of justice (the not yet known), fiduciary indeterminacy compels us to resource the unknowable. To differentiate these concepts I will make use of Adorno's distinction between dialectical and negative dialectical

it from the limitations of its fullness and from building a wall [Wand: interior wall] between itself and the object, indeed from presupposing its being-for-itself as the in-itself and foritself."). 
categories.

\section{Dialectics: Adorno in relation to Hegel}

The concept of dialectics has experienced significant historical change, and as a result is subject to radically differing understandings. ${ }^{402}$ Accordingly, it is critical to distinguish Adorno's usage, which straddles epistemological and normative dimensions. ${ }^{403}$ A rough distinction ${ }^{404}$ can be made between science and dialectics. Science moves from "sensually perceptible existing projections und advances from such to a selfasserted objective." ${ }^{405}$ Dialectics moves

[...] from substrate of belief to a sui generis principle that depends on no pre-condition, and without being facilitated by projections which are utilized in the first categories of the cognizable, using pure concepts to advance along the path of scientific advancement. ${ }^{406}$

For Adorno, dialectics is the living accommodation of antinomy, and a threshold moment in epistemology and

402 See generally Hans Heinz Holz, Dialektik: Problemgeschichte von der Antike bis zur Gegenwart (Darmstadt: WBG (Wissenschaftliche Buchgesellschaft), 2011).

403 On the continuing relevance of dialectical thinking, see generally Hegel, Adorno, and the Concept of Transcendent Critique, Andrew Buchwalter, Dialectics, Politics, and the Contemporary Value of Hegel's Practical Philosophy (New York: Routledge, 2012) at ch 12 .

404 For a critique of the interdepence of dialetic and analytic traditions see Joseph J Russell, Analysis and Dialectic: Studies in the Logic of Foundation Problems (The Hague: M Nijhoff, 1984). 405 Helga Gripp-Hagelstange, Theodor W Adorno: Erkenntnisdimensionen negativer Dialektik (Paderborn: F Schöningh, 1986) at 31. [translated by author]. 406 Ibid. 
justice. As he summarizes:

In dialectics the rhetorical moment takes [...] the side of content. Dialectics seeks to master the dilemma between [...] that which is nonessentializingly correct, mediating this with the formal, logical one. It tends however towards content as that which is open, not already decided in advance by the scaffolding: as protest against myth. That which is monotonous is mythic, ultimately diluted into the formal juridicality of thinking. The cognition which wishes for content, wishes for utopia. This, the consciousness of the possibility, clings to the concrete as what is undistorted. It is what is possible, never the immediately realized, which obstructs utopia; that is why in the middle of the existent it appears abstract. The inextinguishable color comes from the not-existent. Thinking serves it as a piece of existence, as that which, as always negatively, reaches out to the not-existent. Solely the most extreme distance would be the nearness; philosophy is the prism, in which its colors are caught. ${ }^{407}$

Adorno's intention is to seek out the dialectical aporetic immanence of conceptual thought; to expose how in its deepest structuring, conceptual thinking is ultimately driven to its opposite, the non-conceptual.

Adorno further defines dialectics as:

to begin with nothing more than that objects do not vanish into their concept, that these end up in contradiction with the received norm of the adaequatio. The contradiction is not what Hegel's absolute idealism unavoidably transfigured it into: no Heraclitean essence. It is the index of the untruth of identity, of the vanishing of the conceptual into the concept. The appearance [Schein] of identity dwells however in thinking itself as a pure form from within. To think means to identify. Conceptual schematas self-contentedly push aside

407 Adorno, supra note 393 at 65-66. 
what thinking wants to comprehend. ${ }^{408}$

Adorno affirms Hegel's analysis of dialectical thought as an epistemic and normative unavoidability.

Negative dialectics proceed through an immanent critique of the epistemic and normative limitations of Hegel's dialectics. Adorno's goal is the illumination of emancipatory justice moments that Hegel's conceptual thought is structurally disabled from seeing. Hegel's ontological theory of knowledge appropriates and radicalizes the Enlightenment in its anthropological implications. The power of reason not only renders natural laws knowable, but also enables the subject to take an epochal step towards autonomy. For this reason, Hegel's ontological theory of knowledge is, from its very beginning, a theory of emancipatory justice. The system of Hegel's philosophy gestures toward an image of humanity that has no more need of any external, alien determination. This does not imply that the subject simply creates itself; rather the subject is free, operating within a reciprocal relationship among truth, reason, reality and its own subjectivity.

Hegel surpasses the problematic of Kant's inacces-

408 Ibid at 5 . 
sible "thing-in-itself" by seeking theoretical proof that knowledge cannot or must not arise from out of being itself. For Hegel, being is not an independent category; it is only a part of a system of logical relations whose developmental laws are knowable, and are reflected back to and within the human mind.

Inasmuch as humans have access to this epistemic faculty, they not only have access to truth, but also the capacity to bring themselves into harmony with freedom and reason, which for Hegel is virtually synonymous with the demand of justice.

For Hegel, humans bear the final responsibility not just for the measure of reason and freedom within their own subjectivities, but for the construction of society as well. Hegel draws these radical conclusions from the revolutionary social, political and scientific developments of his time.

Hegel's account of human freedom and its relation to the will is decisive for his concept of emancipatory justice. His modern vision of humanity is marked by the potential for constantly renewed selfpositing. 409 Human beings have no divine or worldly ad-

409 Georg WF Hegel, Hegel's Philosophy of Right, translated by Thomas Malcolm Knox (New York: Oxford University Press, 1975) at 34 . 
vantage apart from the fact of consciousness and the consequences of their acts of willing. Subjects only are insofar as they become. In becoming, the will also becomes determined:

Pursuant to the moment of the particularity of the will, it has in addition a content consisting of determinate aims and, as exclusive individuality, it has this content at the same time as an external world directly confronting it. ${ }^{410}$

A consciousness of this content emerges, which in turn points to a determinate aim in relation to the world:

Personality implies that as this person: (i) I am completely determined on every side (in my inner caprice, impulse, and desire, as well as by immediate external facts) and so finite, yet (ii) none the less I am simply and solely self-relation, and therefore in finitude I know myself as something infinite, - universal, and free. ${ }^{411}$

Consciousness of this freedom "constitutes the concept and the basis (itself abstract) of the system of abstract and therefore formal right." ${ }^{412}$ There is no morality, and no justice, apart from the concept of the free and initially undeterminable expression of the will.

The driving forces of history, society, and of reality itself proceed from the human being's free selfpositing through the free expression of human will.

Ibid.

Ibid at 367 .

Ibid at 36 . 
Hegel asserts:

All passions are nothing other than humanity seeking its particularity in the general. The purely general idea is gravid; it does not lead beyond itself. The active element is initially subjectivity, making the general into something concretely real, ready to hand.[...] The real world represents something doubled, in that the goals and desires of the individual appear in it as the realizing and the general. This external side is simply necessary. ${ }^{413}$

Individuals are compelled to eternalize themselves, and to manifest themselves in external reality. Hegel writes, "that I go over into something different, into the determinate, makes me into something determinate." ${ }^{14}$ A distinctive moment emerges from out of the pure will: "[t]he undetermined is itself determined since it stands opposed to the determined, just as the general stands opposed to the specific, and the infinite to the finite." 415 In this manner, the will has an experience of its own finitude. ${ }^{416}$ It is here that the will becomes subjective. ${ }^{417}$ As the will becomes subjective and determinate, it can only stand as an example of a possible particular will.

413 Georg WF Hegel, Philosophie des Rechts: Die Vorlesung von 1819/20 in einer Nachschrift (Frankfurt am Main: Suhrkamp, 1983) at 49 .

414 Ibid at 60 .

415 Ibid.

416 See ibid ("The will assumes a form, a content - as a goal (an entirely different existence) the determinacy of the will has the form of a subjectivity [...]. The will gives itself form. We name this its goal.").

417 Ibid. 
Nevertheless, this particular will suffers under the limitation of all subjective thought. It is part of a stream of consciousness whose meaning and significance cannot be derived from out of itself. Real freedom demands that the subject be in a position not only to be able to carry out an arbitrary series of moments of willing, but also to be able to abstract from itself: "[a]s we reflect on the will, so we take note that it is purely abstract, pure thought."418

In the final analysis, the capacity for abstraction requires that the individual have the freedom to abandon everything: "I can forsake all the bonds that restrain me, I can even give up the entirety of these bonds of my existence (with my death). It is the moment of complete indeterminacy, generality."419

In order to overcome [aufheben] the contradiction within the will that it is simultaneously free and determined, Hegel postulates the negation of the negation. The freedom of the will presupposes that every self-determination that arises within the process of becoming is freely chosen. After every self-positing, the individual must retain the right to posit itself freely again.

418 Ibid at 59 .

419 Ibid. 
In this way the individual maintains freedom, but also gains the necessary distance not only for freedom in itself, but also for freedom for itself: "[f]initude and infinitude are identically posited, so that the determinacy itself is posited as the general, in such a way that determinacy becomes something for me."420 If the subject then negates the already posited or merely possible individual expression of its own will - a negation of the will in and for itself, because it necessarily reflects the subjective will back upon itself in order to preserve its own freedom then the subject reproduces a moment in which both individuality and the purely abstract are overcome and transcended simultaneously.

This is the image of the free will: "[t]his is the negation of the negation, the overcoming of the limit. That is the true infinite; the concept of the will and its freedom. The speculative concept of the will is freedom, and this is the beginning of our entire science." ${ }^{221}$ That the will can and must continually posit itself anew comprises the interface between its transcendence and the universal:

The concept of the will is initially only a con420 Ibid at 60 . 421 Ibid. 
tent. It is the substance in me that wills. Spirit is the system of that which it wills. Its contents initially have the form of immediacy. [...] But this is not the form that belongs to it. The content must be made to correspond to the form of spirit. It must receive the form of something mine, and this is the form of generality. ${ }^{422}$

The valuation of this dialectical relationship between will and Spirit comprises the heart of Hegel's ontological theory of knowledge, and is in turn critical to his theory of justice.

Hegel expresses the axiom of justice in the following way: "[m]an, insofar as he possesses rights, is absolutely his own end, and never a means, not something outside of his concept." ${ }^{423}$ The only truly human end is to be free: "[r]ight stands opposed to the will. The will is free because it makes something initially internal into something else in external reality. That is its freedom. The system of right is nothing other than the system of self-realising freedom."424 For Hegel, the individual can want nothing other than this form of freedom. ${ }^{425}$ Consequently, Hegel's philosophy is the basis for the concept of eman-

422 Ibid.

423 Cf Immanuel Kant, Groundwork for the Metaphysics of Morals, translated by TK Abbott (Calgary: Broadview Press, 2005) at 88 ("So act as to treat humanity, whether in your own person or in that of any other, in every case at the same time as an end, never as a means only.") .

424 Hegel, supra note 413 at 54.

425 Ibid at 52. 
cipatory justice.

\section{(Negative) Dialectics and the (Non)Identical}

While the emancipatory moment in Hegel's thought is incontestable, Adorno rejects the notion that emancipation is exhausted within the confines of the dialectical concept. The ambivalence of the justice threshold achieved by dialectical negation is comparable for Adorno to the law's ambivalent relation to justice. Emancipation is achieved at the expense of excluding that which cannot be rendered within dialectical negation or sublation. The negative dialectic is an immanent critique of such conceptual hypostasis. ${ }^{426}$

Adorno's affirmation of dialectic is contingent on negotiating antinomy. On the one hand, Adorno asserts that the concept, Begriff, ${ }^{427}$ is in contradiction with the thing that it represents.

The concept is the aggregate of subordinate characteristics. Significant qualities of otherness of the object are not represented in the concept. On the oth-

\footnotetext{
${ }^{426}$ Anke Thyen, Negative Dialektik und Erfahrung: Zur Rationalitat des Nichtidentischen bei Adorno (Frankfurt am Main: Suhrkamp, 1989) at 111 ("Thought displays the ambivalence of both instrumental and non-instrumental reason. Thought is also reflection against the quasi-naturally dominant survival instinct.") [translated by author].

427 Adorno, supra note 394 at 11.
} 
er hand the concept is capable of being more than an aggregate of characteristics. Adorno writes,

In certain respects dialectical logic is more positivistic than the positivism which condemns it: it respects the object which is to be thought as thought, even there, where it does not follow the rules of thought. Its analysis is tangential to the rules of thought. Thought need not remain content with its own juridicality; it has the capacity to think against itself, without sacrificing itself; were a definition of dialectics possible, this might be one worth suggesting. ${ }^{428}$

An axiomatic conclusion of the Hegelian process of dialectical negation is the finding that the given (in the abstract) represents a state of reason, and that the zenith of legitimate (and just) subjectivity is found in the sublation of its own contingent reason in order to be united with the overarching reason of the existing. ${ }^{429}$ For Adorno this affirmation is untenable. The totality is not true or legitimate simply because it is. ${ }^{430}$

Adorno describes the ambivalence of dialectics as follows:

428 Ibid.

429 See ibid at 12. ("If the existent is to be totally deduced from the spirit, then the latter would be doomed to become similar to the mere existent, which it meant to contradict: otherwise the Spirit and the existent would not harmonize. Precisely the insatiable identity-principle perpetuates the antagonism by means of the suppression of what is contradictory.").

430 See Adorno, supra note 393 at 38 ("The system-producing ego principle, the prescribed method purified of every sort of content, was from time immemorial the ratio. It is not delimited by anything outside of it, nor through so-called intellectual orders.") . 
The contradiction is the non-identical under the aspect of identity; the primacy of the principle of contradiction in dialectics measures what is heterogenous in unitary thinking. By colliding against its own borders, it reaches beyond itself. Dialectics is the consistent consciousness of nonidentity. [...] Thanks to the immanent nature of consciousness, that which is in contradiction has itself the character of inescapable and catastrophic nomothetism [Gesetzmäßigkeit]. Identity and contradiction in thinking are welded to one another. The totality of the contradiction is nothing other than the untruth of the total identification, as it is manifested in the latter. Contradiction is non-identity under the bane [Bann] of the law, which also influences the nonidentical. ${ }^{431}$

Adorno's ND pursues dialectical negativity, qua antinomical burdening, without affirmative outcome. The Hegelian conception of positive infinity, a system that defines itself through "pure becoming," turns the "constitutive nature of thinking" into metaphysics, thereby eliminating the antinomical capacity for imaging the heterogeneous. ${ }^{432}$

The Hegelian system is not one of true becoming for Adorno, because it "was already preconceived in each particular determination. Such assurance condemned it to untruth."433 Instead, Adorno's negative dialectical approach seeks to illuminate the contradictions in the interdependence of the epistemic or- 
dering and the justice deficits within society.

Such an analysis does not generate affirmation or "legitimacy", but rather a greater responsibility towards justice alterity and indeterminacy. Adorno describes the result: "[r]econciliation would be the meditation on the no-longer-hostile multiplicity, something which is subjective anathema to reason. Dialectics serves reconciliation. It dismantles the logical character of compulsion, which it follows". ${ }^{434}$ Adorno asserts that a negative dialectic pursues reasoning that cannot terminate in the identical, but resources the epistemic and normative space around the non-identical. ${ }^{435}$

Adorno styles the non-identical as that in which:

Hegel, in accordance with tradition, proclaimed his disinterest: in the non-conceptual, the individual and the particular; in what, ever since Plato, has been dismissed as transient and inconsequential and which Hegel stamped with the label of lazy existence. ${ }^{436}$

Negative dialectics not only focuses on that which is

\footnotetext{
434 Ibid at 8 .

435 See ibid at 1 ("Already in Plato dialectics intended to establish something positive through the thought-means of the negation; the figure of a negation of the negation named this precisely. The book would like to emancipate dialectics from these types of affirmative essence, without relinquishing anything in terms of determinacy. The development of its paradoxical title is one of its intentions."). 436 Ibid at 10 .
} 
excluded from conceptual reasoning. ${ }^{437}$ It illuminates the structural illegitimacy of conceptual thinking, while not leaving its side.

Dialectical negation is synchronously driven to confront its own insufficiency. Adorno describes the interweaving of the two as follows:

The requirement that philosophy must operate with concepts is no more to be made into a virtue of this priority than, conversely, the critique of this virtue is to be the summary verdict over philosophy. Meanwhile, the insight that its conceptual essence would not be its absolute in spite of its inseparability is again mediated through the constitution of the concept; it is no dogmatic or even naively realistic thesis. Concepts such as that of being in the beginning of Hegel's Logic indicate first of all that which is emphatically non-conceptual; they signify, as per Lask's expression, beyond themselves. It is in their nature not to be satisfied by their own conceptuality, although to the extent that they include the nonconceptual in their meaning, they tend to make this identical to itself and thereby remain entangled in themselves. Their content is as immanent in the intellectual sense as transcendent in the ontical sense to such. By means of the selfconsciousness of this they have the capacity of discarding their fetishism. Philosophical selfreflection assures itself of the non-conceptual in the concept. ${ }^{438}$

The Sisyphean burden of being unable to relinquish the unavoidable conceptualizing, while at the same time being responsible for rendering justice to the nonidentical, echoes a fiduciary responsibility.

437 This would be similar to the relationship of equity to law, standing in or taking up claims on an ad hoc basis.

438 Adorno, supra note 393 at 16. 
Essential inadequacy to the task does not deprive it of its value; the absence of adequate agency corresponds with the potential to achieve otherwise impossible emancipatory outcomes. Adorno writes:

The less the identity between the subject and object can be ascertained, the more contradictory what is presumed to cognize such, the unfettered strength and open-minded self-consciousness. Theory and intellectual experience require their reciprocal effect. The former does not contain answers for everything, but reacts to a world which is false to its innermost core. Theory would have no jurisdiction over what would be free of the bane of such. ${ }^{439}$

For Adorno, there is a constant normative inadequacy to the prerequisites for conceptual thought, which he condenses into the "logic of identity". ${ }^{440}$

Adorno sees the ND as attendant in the bestimmte Negation (determinate negation) of the given. Such negation does not, by definition, allow for its own reification. It cannot pre-empt the process of the given coming into being, but it is immanent to it. In this narrow sense, a negative dialectical analysis cannot produce a normative outcome or bar the coming into being of illegitimacy. Its form of analysis is always counter-factual and causally unconnected. The re-

439 Ibid at 47.

440 His relationship to this changed notably over time from the Dialectic of Enlightenment, through to the Negative Dialectics, and finally to his unfinished Aesthetic Theory. 
sources necessary for it will always be in competition with those deployed within causal contexts, and as a result, be subject to structural prejudice. For this reason a justice horizon made visible by a negative dialectical analysis will always be inefficient, and will bind resources in a way that may be considered illegitimate.

In contrast, Hegel's bestimmte Negation described an immanent process that sequentially and dialectically develops an underlying legitimacy that manifests in the present and in our overlapping capacity to recognize it. Through it consciousness becomes validated by the ability ex post to recognise the result of becoming. Negation is the very constituent of both reality for us and the attendant conceptual framework which gives existential experience structure, and to an extent meaning. ${ }^{441}$ Adorno characterizes Hegelian subjectivity as follows:

According to strategic necessity he denounces the individuated as if it were the immediate, whose appearance [Schein] he himself is destroying. With this however the absolute contingency of individu-

441 See Adorno, supra note 393 at 27 ("To think is, already in itself and above all particular content, negation, resistance against what is imposed on it; this is what thinking inherited from the relationship of labor to its raw material, its Ur-image. [...] The effort which is implied in the concept of thinking itself, as the counterpart to the passive intuition, is already negative, the rejection of the overweening demand of bowing to everything immediate." ). 
al experience disappears, too. It would have no continuity without concepts. Through its participation in the discursive medium it is, according to its own determination, always at the same time more than only individual. The individuated becomes the subject, insofar as it objectifies itself by means of its individual consciousness, in the unity of itself as well as in its own experiences: animals are presumably bereft of both. Because it is universal in itself, and as far as it is, individual experience also reaches into that which is universal. Even in epistemological reflection the logical generality and the unity of individual consciousness reciprocally condition one another. ${ }^{442}$

Subjectivity is relegated within the Hegelian model to synchronizing itself with the truth content of the given, itself then by idealistic extension always legitimate ex post facto. ${ }^{443}$ For Adorno such affirmation is proscribed:

The immanent critique of idealism defends idealism, to the extent it shows how far it is defrauded by itself; how much that which is first, which is according to such always the spirit, stands in complicity with the blind primacy of the merely existent [Seiendes]. ${ }^{44}$

A negative dialectical analysis is not dependent on the dialectical unfolding of the given through bes-

442 Ibid at 70 .

443 There is some confusion surrounding the use of this term regarding Hegel. As Kojève points out, in the main Hegel does not assert the power of some idealistic force from which the existing is moved. The existing, in the process of becoming, actualizes an underlying coherence whose aggregate he terms the spirit. The idealistic moment enters the constellation when Hegel legitimates this concept sui generis. See Alexandre Kojève, Introduction à la lecture de Hegel: leçons sur la Phénoménologie de l'esprit professées de 1933 à 1939 à l'Ecole des hautes études (Paris: Gallimard, 1968).

444 Adorno, supra note 393 at 45. 
timmte Negation to reveal its actuality. The legitimation and justice deficit that it imagines is always already present, and thus already capable of being a source of emancipation and transformation before the unfolding of events. It is in this sense that a negative dialectical analysis is asserted to be a threshold justice moment.

A left-Hegelian dialectical interpretation would in contrast privilege emancipation through an affirmation of the unfolding through contradictions of stages of development that overcome the existing and the given. The concept of revolution, relying on the radicalizing direction of Hegelian subjectivity, is conceptually occupied by a justice imaginary that asserts legitimacy through recognizing and facilitating the "truth" contained within this process. ${ }^{445}$

In a negative dialectical approach, the aggregate justice deficit that has been produced is always already revealed in the economy of affirmation's relationship to antinomical burdening. Whereas embracing bestimmte Negation does lead us to a partial methexis (participation of the concept in being), the ND inter-

445 See ibid at 9 "Hegel's substantive philosophizing had as its fundament and result the primacy of the subject or, in the famous formulation from the introduction to the Logic, the identity of identity and non-identity." 
rupts its self-referential affirmative character. The net effect of this is to displace the locus of emancipatory justice claims.

For Adorno, the constitutive antinomy of Hegel's dialectic lies in the opposition between: (i) the perpetual dialectical transformation of categories, viz. the constituent conceptual elements that taken together reproduce the meaning horizon on which the experience of contingent reality is based; and (ii) the immutability of logical concepts that are assumed to be active in the process. This antinomy has as a consequence that the radical dynamic of Hegelian dialectics is arrested. In contrast, Adorno's vision sees the moment of synthesis as the "expression of the nonidentity of thesis and anti-thesis."446

Adorno thus concentrates on the dissonance between two intertwined moments. On the one hand, there is the threshold moment producing dialectical epistemological categories (i.e. that dialectics is something that we can consider to be true). On the other hand, there is the perpetually dynamic moment in which categories of dialectical reality are self-sublated (if we abstract from the Hegelian idealistic moment) to produce a syn-

446 Adorno, supra note 394 at 52. 
thesis of inadequacy. Affirmation is impossible, because the outcome, although "true", does not eliminate the constituent elements, both in thought and in real outcomes. The persistence of the threshold moment is not proof of the legitimacy of the result as much as it is the index of its futility.

In this context, Adorno speaks of the ND as an "ensemble of model-analyses":

The demand for committalness [Verbindlichkeit] without system is that for thought-models. These are not of a merely monadological sort. The model strikes the specific and more than the specific, without dissolving it into its more general master-concept. To think philosophically is so much as to think in models. ${ }^{447}$

In this sense, at the same time as experiencing the inevitability of the transformational moment of bestimmte Negation, Adorno's perception of emancipation relies on enabling the capacity to see its outcome as an expression of illegitimacy and inadequacy. This does not foreclose identification with emancipation, but rather internalizes the justice deficit produced as a measure and threshold concept of legitimacy.

Adorno would argue that positive (i.e. Hegelian) dialectics is incapable of fulfilling its selfunderstanding because of its focus on intrinsic

447 Adorno, supra note 393 at 43. 
claims. Negative dialectics pursues the same goal as the extrinsic pole of equity. It focuses on the nonidentical as a Doppelgänger to conceptual thought. The intention is to require our enabling towards a totality of forms of otherness that are normatively relevant for the object and our relationship to it. For Adorno this is not an abstract exercise:

If philosophy is concerned with the real, then it is evident that a purely contemplative relation to this reality, a relation that does not envisage any practical action, is nonsensical because an act of thought about reality is - whether consciously or not - always a practical act. ${ }^{448}$

Adorno asserts that negative dialectics actualizes the objective of theory being emancipatory normative praxis. ${ }^{49}$ The epistemological characteristic of the ND is inseparable from its normative dimension.

\section{Constitutive Subjectivity}

The Begriff (concept) is both the necessary historical prerequisite for constitutive subjectivity and an irrational husk disabling subjectivity. Dialectic is for Adorno not only the way of the Begriff but also the means by which its own inadequacy may become mani-

448 Adorno, supra note 394 at 48.
449 Ibid at 37 . 
fest. ${ }^{450}$ Adorno writes:

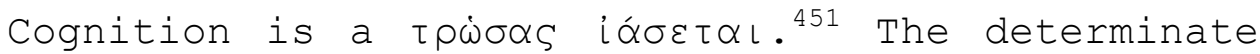
failure of all concepts necessitates the citation of others; therein originate those constellations, into which alone something of the hope of the Name has passed. The language of philosophy approaches this latter through its negation. What it criticizes in words, its claim to immediate truth, is almost always the ideology of the positive, existing identity of the word and the thing. Even the insistence on the specific word and concept, as the iron gate to be unlocked, is solely a moment of such, though an indispensable one. In order to be cognized, that which is internalized, which the cognition clings to in the expression, always needs something external to it. ${ }^{452}$

Constitutive subjectivity is an unavoidability, without which there is no consciousness of illegitimacy of an economy of affirmation or the legacy subjectivity upon with it depends. The ND is directed at the justice challenge of this antinomy. ${ }^{453}$

The primacy of the object in Erkenntnis ${ }^{454}$ does not mean that the object is to replace the epistemic fulcrum of constitutive subjectivity. ${ }^{455}$ The justice claim

\footnotetext{
450 See Menke \& Honneth, supra note 364 at 18 ("Up until now one can only conclude from the opposite to positive dialectic, that the proof of the insufficiency of conceptual determinations is not to be seen as a lack to be overcome, but must rather be seen as a real outcome.") [translated by author].

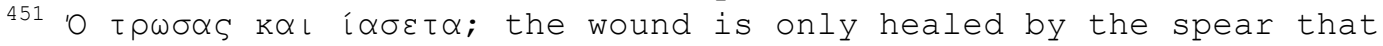
caused it.

452 Adorno, supra note 393 at 82.

453 Adorno writes, "[s] ince the author has trusted himself to follow his own intellectual impulses, he felt it to be his task to break through the delusion of constitutive subjectivity by means of the power of the subject." see ibid at 2 .

454 see supra note 118.

455 See generally, Norbert Schneider, Erkenntnistheorie im 20. Jahrhundert: klassische Positionen (Stuttgart: Reclam, 1998).
} 
of the ND obliges constitutive subjectivity to meet the aporetic impossibility of making the object an epistemic partner. The primacy of the object is one that necessitates the added embrace of the non-conceptual.

Adorno distinguishes Kantian epistemology when he describes the non-conceptual as follows:

Sensations, the Kantian matter, without which the forms could not even be imagined, which are therefore the conditions of the possibility of cognition in their own right, have the character of that which is transient. The non-conceptual, inalienable from the concept, disavows its being-initself and transforms it. The concept of the nonconceptual cannot pause by itself, in epistemology; this necessitates the substantiality of philosophy. ${ }^{456}$

Adorno does not remain within the aporia of the philosophy of mind. ${ }^{457}$ Adorno explicitly situates the justice moment of the ND within the constellation of a counter-factual justice imaginary, based on the structural inadequacy and necessity of constitutive subjectivity.

Adorno's ND turns the task of Erkenntnis into a confrontation with our ability to allow for and generate the limitlessness of the meaning of the object. To do justice to the object demands an epistemic process

\footnotetext{
456 Adorno, supra note 394 at 5.

457 The shortcomings of Habermas's reception of Adorno are explored in Claudia Rademacher, Versöhnung oder Verständigung?: Kritik der Habermasschen Adorno-Revision (Lüneburg: Klampen, 1993).
} 
for which the moment of knowledge is always inadequate and where we are charged with continuing to inquire, not only for the sake of the object, but also for the sake of the legitimacy of the entire undertaking. The contingency of the Erkenntnis moment is critical, Adorno writes "[...] that truth content contains an element of time instead of subsisting in time and appearing as something eternal and indifferent to it." 458

Non-conceptual truth and justice claims are the means by which Adorno intends to transcend the limits of the philosophy of consciousness, by not only confronting it with its immanent contradictions, but also with its correlative substantive alterity. ${ }^{459}$ This is the core mirroring that is commonly understood in the prismatic characteristic of the ND. Alterity is that which is other to Erkenntnis but essential to it; the substratum to which Erkenntnis is beholden. Adorno writes, "[t]he concept cannot otherwise represent the thing which it repressed, namely mimesis, than by appropriating something of this latter in its own mode

\footnotetext{
458 Adorno, supra note 394 at 86.

459 See Adorno, supra note 361 at 64 ("Truth is objective and not plausible. [...] It loses its privileged character, which rancour holds against it, by not allowing itself to be talked out of the experiences to which it owes itself, but rather allows itself to enter into configurations and explanatory contexts which help make it evident or convict it of its inadequacies. Elitist arrogance has not the least place in philosophical experience.").
} 
of conduct, without losing itself to it." ${ }^{460}$

Despite the ephemeral character of the ND as immanent critique, Adorno does not want to relinquish the force of philosophical system:

And it is from this standpoint that I would ask you to understand the concept of a negative dialectic: as the consciousness, the critical and self-critical consciousness of such a change in the idea of a philosophical system in the sense that, as it disappears, it releases the powers contained within itself. This is along the lines of what we may say of theology, since in this latter case the process of secularization released the idea of the system as the idea of a coherent, meaningful world. ${ }^{461}$

This paradoxical and somewhat enigmatic position can be interpreted as creating a form of Doppelgänger for the economy of affirmation.

Immanent critique does not lead us to the conjecture that the economy of affirmation can be overcome by knowledge of it. This would be simple dialectical sublation, another proscribed serial affirmation. Instead, Adorno asserts that we must contemplate that which would respond to the same need or state without the capacity of replacing it. He writes: "[w]e might say that in this sense the unity of thought is always to be found in whatever it negates in its historical

460 Ibid at 21.

461 Adorno, supra note 394 at 38. 
context, in its specific situation."462 Adorno goes on to assert that the ND is "antisystem": "[w]ith logically consistent means, it attempts to put, in place of the principle of unity and of the hegemony of the supra-ordinated concept, that which would be outside of the bane of such unity." 463

The concept of the non-affirmative Doppelgänger is fundamental to Adorno's understanding of critique. He writes,

[...] my postulate would then be that the power of the system - what at one time was the unifying power of a structure of thought as a whole - had to be transformed into the criticism of individual detail, of individual phenomena. ${ }^{464}$

Criticism here has a double meaning. Adorno begins the ND by emphasizing, that "[p]hilosophy, which once seemed outmoded, remains alive because the moment of its realization was missed."465 In this terse note Adorno lays the groundwork for the Doppelgänger. The manner in which the analysis of aggregate justice is related to inadequacy, both ex ante and ex post, provides a premonition of the fiduciary constellation.

The ND's systemic characteristic, in contrast with a conventional justice claim, is embodied in a contin-

462 Ibid at 40.

463 Adorno, supra note 393 at 2.

464 Adorno, supra note 394 at 40.

465 Adorno, supra note 393 at 1 . 
uous process of determining the right relationship to the object. As Adorno notes,

cognition throws itself à fond perdu at objects, so as to be fruitful. The vertigo which this creates is an index veri; the shock of the revelation, the negativity, or what it necessarily seems to be amidst what is hidden and monotonous, untruth only for the untrue. ${ }^{466}$

The manifest inadequacy to the task, just as in the fiduciary relationship, is, counter-factually, neither delegitimizing, nor an abandonment of capacity .

\section{The Economy of Affirmation and Adorno}

The economy of affirmation brings together two strands originating in critical theory. ${ }^{467}$ In that tradition, affirmation is roughly understood as an epistemic identification that may be logically or empirically formed, but which is maintained by the exclusion of epistemically or normatively material non-identity. The affirmation creates a form of illegitimate, if plausible closure. Adorno writes:

The non-identical is not to be won immediately as something positive for its part and also not through the negation of the negative. This latter is not itself, as in Hegel, the affirmation. The

466 Ibid at 49 .

467 See Brian O'Connor, Adorno's Negative Dialectic: Philosophy and the Possibility of Critical Rationality (Cambridge, MA: MIT Press, 2004) at IX ("Critical theory is [...] a consciousnessraising critique of society in which empirically specific aspects of society are examined."). 
positive, which to him is supposed to result from the negation, has more than just its name in common with that positivity which he fought in his youth. The equation of the negation of the negation with positivity is the quintessence of identification, the formal principle reduced to its purest form. With it the anti-dialectical principle wins the upper hand in the innermost core of dialectics, that traditional logic, which more arithmetico [Latin: in mathematical terms] books minus times minus as a plus. It was borrowed from that mathematics, against which Hegel otherwise so idiosyncratically reacted. If the whole is the bane, the negative, then the negation of the particularities which have their epitome in that whole remains negative. Its positive would be solely the determinate negation, critique, not a circumventing result, which the affirmation could happily hold in its hand. In the reproduction of an opaque immediacy which, as something come to be, is also appearance [Schein], the very positivity of the mature Hegel bears marks of what according to predialectical usage is bad. ${ }^{468}$

Consequently, affirmation is understood as the opposite of what is commonly experienced.

Whereas affirmation would normally produce an overlap or investment between categories of cognition and knowledge, Adorno reads this as the means by which subject and object are alienated. O'Connor summarizes the point as follows:

As a contribution to critical theory the "negative dialectic" provides an account of how we might criticize the irrationality of contemporary society. It takes seriously the Hegelian idea of "experience" in which a "consciousness" confronted by a body of data that does not cohere with its concept of knowledge must revise its concept.

468 Adorno, supra note 393 at 161. 
[...] Or the reality of reification might become knowledge to an individual struck by the inability of her concepts to determine adequately some given object. In each of these cases, the rational response is to develop a sophistication of conceptual framework. [...] Adorno approaches the question of the possibility of critical rationality through epistemological considerations. This necessarily deprives it of a certain specificity. But its strength lies in its capacity to defend a notion of rational experience (contrasted with 'withered' experience). Again and again his critiques of the key positions of contemporary philosophy are conducted through an enquiry into what conditions must pertain if experience is to be possible. And finding these positions problematic he charges not simply that they make philosophical errors, but that they operate under erroneous models of rationality, models that, in various ways divide subject and object, rather than expressing their mutual mediation. ${ }^{469}$

In this sense, the concept of affirmation is one that

is discredited in Adorno's ethical epistemology.

The concept of economy, ${ }^{470}$ like affirmation, is

held in particular derision by Adorno:

The more consistently however the legal system is constructed throughout, the more incapable it is of absorbing that which has its essence in refusing absorption. The rational system of law allows the claim of fairness, which meant the corrective of the injustice in justice, to be regularly stricken down as a species of patronage, as unfair privilege. The tendency to do so is universal, of one mind with the economic process, which reduces individual interests to the common denominator of a totality, which remains negative, because it distances itself by means of its constitutive abstraction from the individual interests, out of which it is nevertheless simultaneously

469 O'Connor, supra note 467 at 167 .

470 The term economy is derived from the Greek, olkos house + vópos law or custom. 
composed. The universality, which reproduces the preservation of life, simultaneously endangers it, on constantly more threatening levels. The violence of the self-realizing universal is not, as Hegel thought, identical to the essence of individuals, but always also contrary. They are not merely character-masks, agents of value, in some presumed special sphere of the economy. Even where they think they have escaped the primacy of the economy, all the way down to their psychology, the maison tolérée of what is unknowably individual, they react under the compulsion of the generality; the more identical they are with it, the more un-identical they are with it in turn as defenseless follower. ${ }^{471}$

Adorno's deep misgivings about seemingly natural limits on our scope of epistemic or normative enabling led him to place alterity and the emancipatory as always beyond them. The critique of affirmation and economy evince a left-Kantian ethical and epistemic debt to the object. This debt arises because of the structural limitations produced by constitutive subjectivity.

The deep tendency ${ }^{472}$ toward conceptual affirmation iterates disappointment ${ }^{0 / 1}$, at the same time as providing the horizon upon which continuous disappointment can be cognized. In this sense, the economy of affirmation is a core antecedent antinomy of constitutive subjectivity. The unavoidability of this antecedent antinomy is the cause of the essential justice failing

471 Adorno, supra note 393 at 305 .

472 I would use the word Urtendenz. 
of legacy subjectivity. Constitutive subjectivity, the legal subject, and legacy subjectivity are symbiotic.

\title{
The Non-identical and Disappointment ${ }^{0 / 1}$
}

\author{
The alterity that Adorno explores, while admit- \\ ting the performative contradiction of constitutive \\ subjectivity (i.e. that it is the pre-requisite for \\ any emancipatory consciousness), does not model jus- \\ tice claims that would be attendant on any such con- \\ stitutive subjectivity. To summarize, epistemic alter- \\ ity may be limitless, and this may be truer than any \\ other assertion. It may also be more "legitimate" to \\ confront our inadequacy to alterity and to accept the \\ attendant justice burdens. We must then, in divergence \\ from Adorno's position yet in a parallel move, sustain \\ the reproducibility of constitutive subjectivity's \\ normative capacity while creating relationships of \\ concrete alterity that inflect the totalizing separa- \\ tion brought about through negative dialectics. \\ The ND's focus on negation of negation without \\ affirmation, referred to succinctly in Adorno's short \\ form for a fundamental antinomy of the ND, Geistige \\ Erfahrung [spirit experience], is the willingness to \\ contextualize sensual experiences with conceptualiza-
}


tions whose legitimacy is dependent on immanent critique, refracted through the aggregate justice analysis and outcomes.

In my view, it is questionable whether Adorno follows through with this entirely. ${ }^{473}$ The concept of the economy of affirmation is designed to include preanalytical justice moments, as well as those that remain affirmative despite their banishment from the negation of the negation.

As I have explored at the beginning of this thesis, the problem with legacy subjectivity is that it confuses its justice claims with legitimacy. The concept of the economy of affirmation straddles both sides of this divide. On the one hand it holds up a mirror to the ethical and epistemic blindness of legacy subjectivity. On the other hand it takes Adorno at his word, and asserts the metajustice claim of "illegitimate" subjectivity.

This must be carefully distinguished from a "conservative" position that would defend the reproduction of legacy subjectivity for its own sake. The concept of the economy of affirmation contains the premise that we must also confront the justice antinomy of

473 This is pursued in the fragments of his unfinished Aesthetic Theory. 
having an epistemic or normative consciousness of alterity - an emancipatory justice claim - under circumstances in which every (possible) iteration of this claim will be subject to the contingencies of enabling. In contrast to Adorno, I do not seek to erect justice alterity as the sole and unquestionable criterion of metalegitimacy.

While I share his emphasis on justice alterity and indeterminacy, Adorno's theory lacks for me a normatively apposite concept comparable to the economy of affirmation. Adorno's emphasis in the ND is on structural epistemic deficits. The non-identical, as a radically emancipatory theoretical iteration, grounds the demand for continuous recalibration of the justice imaginary. Yet such metaconcepts can only be normatively material (and I am not making a causal argument here) if their own immanent normativity is also questioned. The immutability of the emancipatory claim is for Adorno a form of redemption. This redemption appears to me to omit the types of eudaemonic thresholds that I explored in the implicit emancipatory claims of legal positivism and natural law. However, Adorno's insights start to have greater normative resonance when considered together with the fiduciary model explored 
here. Fiduciary obligations can be seen to trace out a horizon of continuous inadequacy. The suspension of conventional legal subjectivity and agency counterbalances the implications of disappointment ${ }^{0 / 1}$.

The foregoing can be summarized as follows. Legal subjectivity is a first order negation, the rendering of subjectivity within the bounds of a normative economy of affirmation. As explored at the beginning of this thesis, legal subjectivity is also a form of avoidance of the ambivalence associated with disappointment ${ }^{0 / 1}$ and emancipatory claims. The autopoietic legitimacy of the legal subject is dependent on this avoidance.

The fiduciary relationship is a second order negation that fulfills Adorno's admonition that only a negation of negation that does not assert an affirmative can bridge the gap between critical epistemology and justice theory. The fiduciary relationship negates the negation of the disappointment ${ }^{0 / 1}$ ambivalences, without asserting another affirmation.

Legal categories remain intact but are subordinate to the aggregate justice considerations that remain indefinable and non-identical. The concept of fiduciarian justice, refracted through an understanding of 
the non-identical, overlaps with the emancipatory claim more than any other normative regime.

Adorno's concept of the non-identical can be used for a further level of deconstruction of the relationship between disappointment ${ }^{0 / 1}$ and legal subjectivity. A heightened antinomical sensibility reveals contradictions between the emancipatory and the epistemic:

While thinking does violence [to that upon which] it exerts its syntheses, it follows at the same time a potential which waits in what it faces, and unconsciously obeys the idea of restituting to the pieces what it itself has done; in philosophy this unconsciousness becomes conscious. The hope of reconciliation is conjoined to irreconcilable thinking, because the resistance of thinking against the merely existent, the domineering freedom of the subject, also intends in the object what, through its preparation to the object, was lost to this latter. ${ }^{474}$

This sense of indeterminate burdening towards the epistemological object combined with a contemporaneous sense of structural inadequacy mirrors the analysis I have undertaken of the fiduciary relationship.

On this basis, it can be said that Adorno makes explicit that epistemic antinomical consciousness is already an unavoidable normative threshold. The functionalization of disappointment ${ }^{/ 1}$ in law stands at the opposite pole of the non-identical in the antinomical

474 Adorno, supra note 393 at 28 ND 28. 
enabling of a fiduciary relationship.

As was discussed previously, disappointment ${ }^{0}$ arises from justice claims that cannot be taken up by subjectivity (because that subjectivity is untransformable). Disappointment ${ }^{1}$ arises from the emancipatory projection that has seamlessly been incorporated into the ex post version of self (because that subjectivity is unaddressable by the transformation). The economy of affirmation around the legal is premised on the exclusion of justice alterity, antinomical burdens, and in consequence, emancipatory claims that would undermine its unavoidable status.

Contrary to a normatively utopic emancipatory reading of the "legal" (I have also pointed to the emancipatory justice claims contained within the "legal"), and the related claims connected to the concept of legacy subjectivity, the "legal" expresses its emancipatory claim always also through exclusion of the non-identical. The other-regarding of the fiduciary relationship, in contrast, does not have the goal of reproducing a mirrored (second-order) legal subjectivity, but rather of enabling a mutuality of otherness, open and sustained by the justice indeterminacy of the risk of the moment. 
Disappointment ${ }^{0}$ is structurally contained by constant fiduciary inadequacy. Fiduciary obligations cannot normally be determinately affirmed. Thus, the risk and consequences of disappointment ${ }^{0}$ are internalized to the fiduciary regime. Disappointment ${ }^{1}$ is avoided for the beneficiary. The beneficiary's first order subjectivity is never directly served by the fiduciary relationship. In contrast, the exclusion of the nonidentical in the "legal" reduces the capacity for the differentiation between disappointment ${ }^{0}$ and disappointment ${ }^{1}$.

The legal economy of affirmation reproduces legitimacy specifically in relation to its capacity to displace other forms of knowledge. Adorno writes:

Thinking is capable of critically cognizing the compulsory character immanent to it; its own inner compulsion is the medium of its emancipation. The freedom towards the object, which in Hegel resulted in the disempowerment of the subject, is first of all to be established. Until then, dialectics diverges as method and as one of the thing. Concept and reality are of the same contradictory essence. What tears society apart antagonistically, the dominating principle, is the same thing which, intellectualized, causes the difference between the concept and that which is subordinated under it. The logical form of the contradiction however achieves that difference, because every one which does not suborn itself to the unity of the dominating principle, according to the measure of the principle, does not appear as a polyvalence which is indifferent to this, but as an infraction 
against $\operatorname{logic}{ }^{475}$

In contradistinction, a negative dialectical account of justice externalities does not dislodge the economy of affirmation. This would merely have the effect of producing some other form of implicit or explicit affirmation. Indeed it would have the effect, for example, of forcing the focus of affirmation into greater forms of irrationality, thus reifying disappointment $t^{0 / 1}$.

The static quality of the legal has an existential dimension. The continuous impression created that there is no possibility other than law, and the creation of sanctions that download all risks to the individual if they attempt to move outside of it, are instrumental in the disabling of any emancipatory sustainability. The reification of disappointment ${ }^{0 / 1}$ retards the consciousness of the role of becoming in being.

This existential stop-gap empowers subjectivity to reproduce itself in a way that creates a commodity of the present, in the sense that it is fungible. Each state of presence is indistinguishable from the next

475 Ibid at 75 . 
as the immutability of disappointment ${ }^{0 / 1}$ proves. ${ }^{476}$ This is one of the poles of legacy subjectivity - the normative center of the logic of identity - and a negative, disabling threshold moment, otherwise known as law's determinacy.

Law can perform this function because it can be made to appear or be contextually reproduced as a moment of choice and a socially affirmed, indeed requisite, interstice. ${ }^{477}$ Adorno writes:

The abstract thesis of the conditionality of every thought is to be most concretely reminded of that of its own, the blindness towards the supraindividual moment, through which individual consciousness alone becomes thought. Behind this thesis stands a contempt of the spirit which prefers the primacy of material relationships, as the only thing which should count. ${ }^{478}$

Looking through the lens of the ND, this prizing of free thought blind to its supra-individual moment is illegitimate because the justice externalities thus produced are in fact downloaded onto the individual. Adorno recapitulates:

The relativity of all cognition can only be main-

476 See ibid at 83 ("Ever since the fundament of all cognition was sought in the presumed immediacy of the subjectively given, there have been attempts, in thrall to the idol of the pure presence, as it were, to drive out the historical dimension of thought. The fictitious one-dimensional Now becomes the cognitive ground of inner meaning.") .

477 See ibid at 55 ("In truth divergent perspectives have their law in the structure of the social process, as one of a preestablished whole.") . 478 Ibid. 
tained from without, for so long as no conclusive cognition is achieved. As soon as consciousness enters into a determinate thing and poses its immanent claim to truth or falsehood, the presumably subjective contingency of the thought falls away. Relativism is null and void simply because, what it on the one hand considers popular and contingent, and on the other hand holds to be irreducible, originates out of objectivity - precisely that of an individualistic society - and is to be deduced as socially necessary appearance [Schein]. ${ }^{479}$

The individual has no recourse, because the facticity of choice exercised implicates one's subjectivity. The creation of this category of presence meets subjectivity with a prototroph, ${ }^{480}$ a meme, whose loss cannot be replaced because it does not exist. The affirmation created around this meme is sufficiently generalizable (i.e. it is democratic) to map onto the perceived threshold positive justice category of generalizable norms (i.e. it is normatively autopoietic).

Those forced to affirm the form of choice modeled here will automatically be more enabled to build affirmational collectives that do not require substantive (real-time) authentication. When survival is the (validly) dominant imperative, looked at dialectically, this affirmational trope satisfies the requirement

\footnotetext{
479 Ibid.

480 "A strain (usually of bacteria or fungi) that can grow on the simplest medium necessary for the growth of its species, without supplementary nutrients." See OED, supra note 15.
} 
of a legitimate positive threshold. Without a surviving individual able to form a collective with others, no differentiated aggregate justice is possible.

However, it is the deep justice critique of the ND that the imposition of a justice and epistemic threshold premised on survival, when looked at from a metatheoretic standpoint, is a moment whose sublation is a pre-requisite for human legitimacy. The ND asserts that self-overcoming is a characteristic of justice per se, and that this must productively embrace the antinomy that Hegel's logic resisted. Subjectivity once achieved is irrevocable, and the relationship to it is open to the utopic moment of sublation in the emancipatory claim, which is no less mutable. It is in fact the $\mathrm{ND}^{\prime} \mathrm{s}$ model of immanent critique of subjectivity that illuminates the necessary interdependence of subjectivity and its own sublation.

To maintain the constant state of lack on which complicit subjectivity depends, deficiency must be constantly re-referenced, and the suppression of emancipatory claims in the constellation of choice described above compensated for. The analysis of this constellation may provide insights into the moral vacuum necessary for the macro-self-destructive behaviour 
reproduced by societies whose resources should enable other outcomes. The negative threshold choice that constitutes legacy subjectivity is potentially at the origin of the need for the usurpation of all resources. ${ }^{481}$

Adorno's ND works to remove the obstacles in consciousness precisely because the shards of identity remaining after their alienation can only be overcome, not by the further alienation through a moral or ethical burden placed upon the individual, but by making the decontextualized, alienated self accept the liberty that this implies. ${ }^{482}$ Adorno is asserting, to simplify, that the freedom that alienation has produced be placed at the service of justice.

The ND directly counters the lack of real freedom exhibited by legacy subjectivity in the perceived im-

\footnotetext{
481 Adorno, supra note 393 at 56 ("Yet the perennial hostility to the spirit is more than a feature of subjective bourgeois anthropology. It is due to the fact that the concept of reason inside of the existing relations of production, once emancipated, must fear that its own trajectory will explode this. This is why reason delimits itself; during the entire bourgeois epoch, the idea of the autonomy of the spirit was accompanied by its reactive self-loathing. It cannot forgive itself for the fact that the constitution of the existence it controls forbids that development into freedom, which lies in its own concept.").

482 see ibid at 62 ("In sharp contrast to the usual scientific ideal, the objectivity of dialectical cognition needs more subject, not less. Otherwise philosophical experience shrivels. [...] In any case the subjective quotient of philosophy, compared with the virtually subjectless rationality of a scientific ideal which posits the substitutability of everyone with everyone else, retains an irrational adjunct. It is no natural quality.").
} 
possibility of making other decisions. The void of becoming without the otherness to this and in this, embodied in the justice constellation, could not anchor a subjectivity with a sufficient relation to choice to be termed free. Without the otherness of the justice aggregate and the emancipatory justice claim, each successive moment of negation would not be contextualizable and subjectivity would become aleatoric. ${ }^{483}$ Justice in this sense is a response to the antinomy of the void in becoming. The justice aggregate, driven by the emancipatory claim, can be seen as infusing the process of becoming with a form of legitimacy that sublates subjectivity.

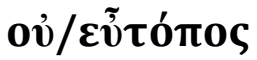

The ND is the attempt to realize an epistemic utopia: "The utopia of cognition would be to open up the non-conceptual with concepts, without making it the

\footnotetext{
483 See Adorno, supra note 394 at 8 ("The absolute first necessarily remains as indeterminate as its opposite; no investigation of what is concretely precedent reveals the unity of what is abstractly antithetical. Rather the rigid dichotomical structure crumbles by virtue of the determinations of each pole as the moment of its own opposite. The dualism is already given in the philosophical thought and as inescapable, as the process by which it becomes false in thought. Mediation is merely the most general, itself inadequate expression for this. - If however the claim of the subject that it is the first, which surreptitiously inspired ontology, is cashiered, then what is secondary according to the schema of traditional philosophy is no longer secondary, in a double sense subordinate.") .
} 
same as them." ${ }^{484}$ Utopia is not here be understood as some form of imaginary that simply is other than the given. ${ }^{485}$ The emancipatory claim does not represent a "place" where we come to rest; and yet it is as much a

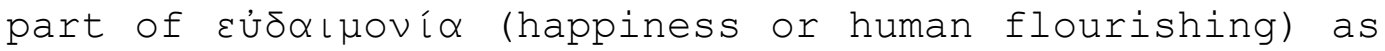
any other virtue.

There is a play on words in the concept of utopia lost to the modern usage. U-topia in English could re-

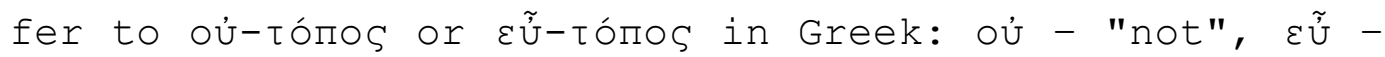
"good", and tónos - "place". A double sense of noplace and good-place emerges from a justice imaginary that has captured the immutability of the emancipatory claim. Adorno asserts:

A faith, as always subject to question, that philosophy would still be possible; that the concept could leapfrog the concept, the preparatory stages and the final touches, and thereby reach the nonconceptual, is indispensable to philosophy and therein lies something of the naïveté, which ails it. ${ }^{486}$

The paradox between a threshold epistemic moment and its legitimacy outside the structure of the economy of affirmation is fundamental to the ND, understood as

484 Adorno, supra note 393 at 13.

485 Adorno "But a mode of conduct which protects nothing as the first or the secure, and yet, solely by power of the determination of its portrayal, makes so few concessions to relativism, the brother of absolutism, that it approaches a doctrine, causes offence." ibid at 51.

454 Adorno, supra note 393 at 13. 
both legitimate critique and praxis. As Adorno himself summarizes:

Ladies and gentlemen, such a philosophy, which on the one hand does not presume to apprehend the infinity of objects but on the other hand does not reduce itself to the finite - such a philosophy would amount to a full, undiminished experience in the medium of conceptual reflection. We might also say, it would amount to intellectual experience. ${ }^{487}$

An economy of affirmation manufactures legitimacy specifically in relation to its capacity to displace other forms of knowledge. "[U]nreduzierte Erfahrung im Medium der begrifflichen Reflexion" - undiminished experience in the medium of conceptual reflection - demands that conceptual thought be exercised and then unmasked. This unmasking does not raise the pretence of being enabled to replace conceptual thought ex ante. Importantly, it does however assert that without this threshold moment the emancipatory claim, and thus any truth, will be occluded. ${ }^{488}$

This has as its corollary the presumption that the

\footnotetext{
487 Adorno, supra note 362 at 82. In the Negative Dialectics, Adorno calls this "nothing other than the full, unreduced experience in the medium of conceptual reflection". See Adorno, supra note 393 at 19 .

488 See Adorno, supra note 393 at 37 ("What the objects communicate in, instead of each being the atom to which classificatory logic reduces it, is the trace of the determination of objects in themselves, which Kant denied and which Hegel wished to re-establish against Kant through the subject. To comprehend a thing itself, not to merely fit it in, to register it in a system of relationships, is nothing other than to become aware of the particular moment in its immanent context with others.").
} 
existing economic and social order is false because of the limitations placed on possible aggregate justice by inadequate epistemic accountability. Yet this constraint would seem a small price to pay for the benefits of the rule of law.

A negative dialectical analysis reveals that the limitation of emancipatory claims to those contained within the conventional pole of the justice matrix enshrines historical injustice. Although the economy of affirmation surrounding the rule of law "rationalizes" justice resources allocated, the ND would hold it inversely responsible for the reproduction of injustice caused by inadequate resourcing of the emancipatory.

Given law's ambivalent relationship to justice, the benchmark for legitimacy is the status/quality of the object/other, and in the broader sense, alterity itself, which for Adorno is normatively inseparable from the emancipatory claim. ${ }^{489}$

\footnotetext{
489 The constellational interdependence of the tributaries to the concept of law is specifically understood in the justice matrix model. Recht und Gerechtigkeit are always in tension. This tension is one that can be found in many traditions. In French, justice and justesse have a more hidden ambivalence than the German; here the tension includes the concepts of directness and fitness. The concept of law includes prehistoric Old Norse lagu, Old Icelandic log, 'something laid or fixed'; the plural had the collective sense 'law'. The Old Norse lag corresponds to the old Saxon lag. Germanic lagom, Latin lēg, lēx is not now generally believed to be cognate, being referred to as the root leg- of legĕre to gather, $\lambda \varepsilon \dot{\varepsilon} \varepsilon\llcorner\nu$ to gather, to say. In many other languages the
} 
Like the concept of utopia, alterity does not mean an abstract otherness. The concept of the nonidentical is developed both in the continuity of all epistemological antecedents to the economy of affirmation, and in the ongoing immanent experience of materially producing individualist subjectivity.

Adorno's analysis is premised on the assertion that we cannot regress behind subjectivity. The justice claim instantiated around alienated subjectivity cannot be overcome. One may come to the limit of one's own real-time cognitive capacity, but subjectivity will always continue to re-articulate the emancipatory justice claim against that limit. It is for this reason that Adorno connects the motor of justice to otherness within the epistemological horizon. The very moment that the economy of affirmation uses to legitimate stasis - that is, avoidance of antinomical overburdening in disappointment $t^{0 / 1}$ - is the moment Adorno seeks to propel through and past in the name of justice.

word for 'law' is derived from roots meaning 'to place'; compare, Greek $\theta \varepsilon \dot{\mu} \mu \mathrm{s}, \theta \varepsilon \sigma \mu o ́ s$, Latin statutum, German gesetz. However, law is the usual English rendering of Latin lex, and to some extent of Latin jus, and of the Greek vópos. Law is mapped onto the conventional pole of the justice matrix, but its meaning can only be understood in its relationship to a complex web of parallel justice theoretical concepts. See OED, supra note 15. 


\section{Justice Reserve and the Fiduciary}

A key ethical contention of the ND is that legitimate Erkenntnis (roughly, knowledge recognition) is not accompanied by the will to affirm its own givenness or that of its other. Erkenntnis can thus embrace epistemic constellations the motive element of which is the justice reserve; that is the ability to be bear disappointment $t^{0 / 1}$.

This outcome corresponds in part with the shift in the justice imaginary explored earlier. The negative dialectical projection of a to be defined alterity on the object of Erkenntnis, (that is, to be disabled from viewing the object as determinate, and to be beholden to its articulation through a counter-facticity - semblance, Schein), when paired with positive dialectical Erkenntnis that invests in the subject, imposes on the subject a justice burden and unavoidability, which is immune from disappointment ${ }^{0 / 1}$. For Adorno,

the point at which [philosophy] is able to demonstrate its true actuality, if indeed it has one, consists in the resistance it offers to the prevailing need for security, in contrast to all current modes of knowledge which have more or less adjusted their sights so as to conform to that need. It is the point at which it realizes that - 
as Nietzsche would have put it - knowledge that is not dangerous does not deserve to be thought. ${ }^{490}$

The danger that Adorno refers to is not distant from the risk of the moment discussed earlier.

Echoes of the fiduciary constellation proliferate when Adorno describes the pursuit of legitimate Erkenntnis as that form of irrationality which is capable of ignoring the right of the given against a right as yet to be defined. The aporetic entanglement of Erkenntnis and legitimacy is described in detail:

We might also say that speculative ratio, the kind of ratio that goes beyond the conceptual order of an already owned, positive given, necessarily possesses an irrational element in that it offends against the secure knowledge it already has. There is no rationality without this intrinsic element of irrationality. However, the moment this element of irrationality is postulated, or turns itself into something autonomous or even an absolute, it degenerates into illusion and lie. ${ }^{491}$

The holding open to a right that is incapable of being defined before the moment of its articulation, which is always at risk of radical invalidity, is analogous to the fiduciary relationship.

This comparison is further accentuated by Adorno's description of "the mimetic element in other words, the moment at which living beings and consciousness make themselves identical with what differs from

490 Adorno, supra note 394 at 127.

491 Ibid at 91 . 
them."492 Adorno affirms an epistemic model in which identification with the object, to be understood as the aggregate and shifting justice claim of its alterity, is necessarily also non-conceptual and mimetic in nature, as is true of aesthetic experience.

Adorno's interweaving of the inadequacy of both aesthetic (non-conceptual) and conceptual Erkenntnis is a further moment upon which aggregate justice critique depends. Non-conceptual Erkenntnis suffers from a "blindness" which causes it to be actualized only in semblance. ${ }^{493}$ Conceptual Erkenntnis has as its medium the Begriff, the barrier that it fails to overcome at the peril of its invalidity. Adorno draws the distinction that "[b]oth keep faith with their own content through their opposition; art, by making itself obdurate against its meaning; philosophy, by not clinging to anything immediate. ${ }^{494}$

The aporetic character of this rhetoric can only be understood properly from a non-affirmational perspective. Adorno is not asserting that the interlocking inadequacy of conceptual and non-conceptual Erkenntnis is the outcome of a negative dialectical

Ibid at 135 .

Ibid at 140 .

494 Adorno, supra note 393 at 22. 
analysis. Instead, these unavoidable inadequacies are threshold moments, contextualized and legitimated by their aggregate justice consequences.

These unavoidabilities create barriers specifically to the legitimacy of the economy of affirmation. As affirmations gain currency they are stripped of any aporetic consciousness; that is, of the means by which their unavoidable inadequacy can be seen as integral to their authority. ${ }^{495}$ Adorno refers to his longeststanding original conceptual framework, his previous iteration of the ND, as the Logik des Zerfalls, or the $\operatorname{logic}$ of decay.

Adorno demarcates negative dialectics as an arrangement of epistemic unavoidabilities. In this arrangement, the relationship of subjectivity to the object of Erkenntnis is enabled by ensuring that the emancipatory claim is not subsumed under the affirmation of constitutive subjectivity. Instead, the epistemic and justice threshold moments act as barriers to illegitimate outcomes. Legitimacy itself is imaginable

\footnotetext{
495 See Adorno, supra note 394 at 127 ("The fact is that philosophy does not have any particular guaranteed object of study; it is possible to think philosophically only where thinking can go awry, where it is fallible. The moment that nothing can happen to philosophical thought, that is, the moment it finds itself in the realm of repetition, mere reproduction, at that moment philosophy will have missed its mark.").
} 
through a process in which subjectivity and the justice imaginary toward alterity share in the potential for an exchange unfettered by commensurability.

The rightful unhinging of the validity of constitutive subjectivity can only take place in a justice constellation that is comparable to the ND. The metric that the ND applies is not itself. ${ }^{496}$ It is for this reason that Adorno's work is open to its own overcoming. ${ }^{497}$ The ND does not constitute its own unavoidability. Adorno's position is unequivocal:

[I]n the philosophical turn I am laboring to explain to you in these lectures, the categories themselves become altered in their contents, just as the concept of speculation has changed. Speculation was originally a category that created meaning, whereas now, according to what I have just been telling you, it is essentially there in order to destroy the semblance of meaning usurped by merely existing actuality. Philosophy is the power of resistance: I believe that a definition of philosophy other than as the intellectual power of resistance simply does not exist. The power of resistance - by not allowing itself to be fobbed off with whatever might deflect it from its true

\footnotetext{
496 See Adorno, supra note 361 at 19 ("Philosophical content is to be grasped solely where philosophy does not mandate it. The illusion that it could captivate the essence in the finitude of its determinations must be given up. Perhaps the word infinite dropped so quickly from the tongues of the idealistic philosophers because they wished to hush up gnawing doubts about the threadbare finitude of their conceptual apparatus, even Hegel's, in spite of his intent. Traditional philosophy believes it possesses its object infinitely, and thereby becomes as philosophy finite, conclusive. A different one ought to cashier that claim, no longer trying to convince itself and others that it has the infinite at its disposal. Instead of this it would become, put delicately, infinite to the extent that it refuses to define itself as a corpus of enumerable theorems."). 497 Gripp-Hagelstange, supra note 405 at 367.
} 
interest; it does not let itself be fobbed off with the facts, as opposed to gratifying its essential needs, even if only through a decided No, in other words, by the demonstration of the impossibility of gratifying them. ${ }^{498}$

The justice outcome that the ND seeks to place above all other considerations is necessarily one that cannot affirm the existing economy of affirmation, nor can it simply be a position of perpetual scepticism. Adorno asserts that "the effort or the resistance of thought consists precisely in refusing such an immediate assertion of the meaningful nature of mere existence. Likewise, depth cannot mean something like the sort of retreat into inwardness [...]." ${ }^{499}$ The ND is not an immaterial step in the trajectory of dialectical thought.

Without the capacity for externalization (Entäußerung) thought is without normative substance and thus only a fragment of what it could be. ${ }^{500}$ Within the constellational model of this externalization is the reproduction of the fiduciary moment, a context in which the emancipatory claim can be legitimately deployed.

The fiduciary moment is made clear in Adorno's

\footnotetext{
498 Adorno, supra note 394 at 148 .

499 Ibid at 155.

500 Ibid at 156 .
} 
ethos of resistance:

[T]he mark of depth nowadays is resistance [...] This means refusing to accept a preordained idea, however profound it claims to be; [...] Resistance means refusing to allow the law governing your own behaviour to be prescribed by the ostensible or actual facts. In that sense resistance transcends the objects while remaining closely in touch with them. ${ }^{501}$

The transcending of the object with the object within the relationship of power that Erkenntnis always automatically is, asserts a fundamental justice and normative threshold. Identical to a fiduciary relationship, this relationship is legitimate only to the degree that the enabling moment, an emancipatory moment per se, permits the existing, the economy of affirmation, and the logic of identity to be safely sublated. The specific justice aggregate achieved by the maintenance of the fiduciary and beneficiary in a state of alterity - a state where their subjectivity is conceded for the benefit of an incommensurable justice outcome can be illuminated using the ND.

\section{Defects of an Emancipatory Algodicy}

The Copernican turn that I am asserting here would entail the resourcing of sustainable justice alterity

501 Ibid at 157. 
and emancipatory claims towards threshold levels of other-regarding. This would have as a consequence that law's legitimacy would depend on its contextualization within non-legal considerations, without succumbing to systemically pre-determined relativism. Antinomical overburdening regularly leads to a justice resource crisis. It is the societal categorization of this crisis that an other-regarding macro-normative transformation would affect.

A substantial difference between the ND and the fiduciary relationship is the weight and character given to the role of the emancipatory claim. Adorno's ND anchors a significant degree of its legitimacy in its relation to algodicy. ${ }^{502}$ For Adorno, legitimate philosophy must be contextualizable with ${ }^{503}$ - and is in fact commensurable with - the articulation of suffering: ${ }^{504}$

What in thought goes beyond that to which it is bound in its resistance is its freedom. It follows the expressive urge of the subject. The need to give voice to suffering is the condition of all truth. For suffering is the objectivity which weighs on the subject; what it experiences as most subjective, its expression, is objectively mediat-

502 See supra note 95 and accompanying text.

503 Adorno cites Goethe here: "And if humans in their agony grow silent; a God gave to say to me, how I suffer." See Johann Wolfgang von Goethe, "Torquato Tasso" in Goethes Werke 5, Dramatische Dichtungen: (Hamburg: Wegner, 1952) at 166.

504 Adorno, supra note 394 at 158. 


$$
\text { ed. } 505
$$

The emancipatory horizon also has moments of algodicy expressed in disappointment ${ }^{0 / 1}$. However, an insupportable moment within the ND may be its focus on the affirmation of the legitimacy of suffering as an index of the object. ${ }^{506}$

Even though Adorno rejects an unthinking affirmation of suffering qua negativity as a form of "empty depth", 507 there is a normative elision towards the privileging of emancipatory alterity marked by suffering. Specifically, a subjectivity transformed by disappointment $t^{0 / 1}$ does not suffer the same way as someone restricted from transformation by the deformations caused by the economy of affirmation. Adorno is dis-

\footnotetext{
505 Adorno, supra note 361 at 25.

506 See ibid at 26 ("This may help to explain why portrayal [Darstellung] is not a matter of indifference or external to philosophy, but immanent to its idea. Its integral moment of expression, non-conceptually-mimetic, becomes objectified only through portrayal - language. The freedom of philosophy is nothing other than the capacity of giving voice to this unfreedom."). 507 Adorno, supra note 362 at 104 ("According to this way of thinking, all thought that takes happiness seriously is deemed shallow, whereas thought is said to be deep if it treats denial and negativity as something positive that gives it meaning. ... What I am saying, then, is that this concept of depth, which amounts to a theodicy of suffering, is itself shallow. It is shallow because, while it behaves as if were opposed to the shallow, rather mundane desire for sensual happiness, in reality it does no more than appropriate worldly values which it then attempts to elevate into something metaphysical. It is shallow, furthermore, because it reinforces the idea that failure, death and oppression are the inevitable essence of things - whereas important though all these elements are and, connected as they are to the essence of things, they are avoidable and criticizable, or at any rate the precise opposite of what thinking should actually identify with.").
} 
missive of such a possibility:

The pure, completely sublimated subject would be on the other hand that which is absolutely traditionless. The cognition which experienced only the idol of that purity, total timelessness, coincides with formal logic, would become tautology; it could not grant even a transcendental logic any room. Timelessness, towards which the bourgeois consciousness strives, perhaps as compensation for its own mortality, is the zenith of its delusion. 508

Adorno asserts here the irrationality of a postsuffering stasis.

"Timelessness" stands in for the identical, which is, as we have explored, the measure of its own illegitimacy. At the same time, the emancipation and enabling of subjectivity towards a transformed relationship to disappointment ${ }^{0 / 1}$ can have no other goal than to shift the ontological, deontological, epistemic, and material moments towards a more differentiated aggregate justice outcome.

Whereas Adorno legitimately criticizes his predecessors for being inconsequential in respect to antinomies, his own position concerning legacy subjectivity displays a conflation between the necessity of embodied non-transcendence, and its legitimate suspension in light of the real possibility of as yet historical-

508 Adorno, supra note 393 at 84 . 
ly unarticulated justice aggregates.

Legacy subjectivity is a justice question - a matter of justice and a problem for justice - not a threshold justice category. In this sense it is difficult uncritically to accept the ND's contextualized notion of utopia on the one hand and its analysis of the "zenith of bourgeois delusion" on the other. ${ }^{509}$ If we take the aggregate justice aspect of the ND as the legitimate source of its metatheory, we are confronted by the "timelessness" of Adorno's fetish of antinomy.

The question remains whether a person having been enabled in the sense that the ND implies would experience emancipation or the need for it in the same way as beforehand. If the experience of emancipation is not a possible legitimate outcome, then the suspicion is created that the ND affirms the potential for emancipation in the consciousness of alterity at the expense of the outcome itself. In this sense the exact justice positioning of legacy subjectivity is a significant moment in the real emancipatory enabling that an ND analysis would methodologically empower.

In fact, as we explored earlier, the economy of affirmation is itself a response to the suffering im-

509 Ibid at 464 . 
manent in antinomical overburdening. This is why I have analyzed it as a node of conventional justice and of legacy subjectivity, contrary to its interpretation within the ND.

The necessity to recur to suffering skews the focus of transformation away from enabling and towards reparation. It is in this sense that, just as the ND is useful for illuminating the workings of the fiduciary relationship, the latter can help to analyze the justice conceptualizaton of the ND. A deep fiduciary relationship could advance a beneficiary's transformation through disappointment ${ }^{0 / 1}$ in such a way that suffering would be altered, or sublated. ${ }^{510}$ In the following section I will examine and apply the forgoing analysis to the concept of the fiduciary, in parallel with an account of how it is already increasingly impacting on macro-normative social outcomes.

510 This vision can be seen as the result of the Negative Dialectics's model of immanent critique applied to the emancipatory claim. 


\title{
Chapter 5: Fiduciary Normativity
}

\author{
The exploration of Adorno's epistemology in the \\ previous chapter prepares the final chapter of this \\ thesis devoted to modeling the fiduciary relationship \\ in law. The purpose of this modeling is to address \\ macro-normative social concerns and not simply to al- \\ low for redress inter partes. I therefore select a few \\ recent cases that display the potential for a macro- \\ normative deployment of fiduciary relationships, not- \\ ing how existing legal constructs still impede access \\ to equity's available justice reserve.
}

The chapter begins with a short account of the ongoing reception of the fiduciary conception through Equity into common law jurisdictions. I then discuss how the law's deployment of the fiduciary relationship opens up the prospect of achieving more than narrowly conceived private law outcomes between individual legal subjects. I draw here notably on the work of Evan Criddle and Evan Fox-Decent, who are among those commentators seeking to find a public law dimension to the fiduciary relationship. I conclude with an analysis of two Supreme Court of Canada cases, Guerin and Elder Advocates, which have begun imperfectly to open 
up the macro-normative potential of the fiduciary conception

\title{
The Reception of the Fiduciary Relationship by Equity
}

\author{
Formal fiduciary obligations emerged relatively \\ late in the history of equity. The prototypical fidu- \\ ciary cases of Walley $v$ Walley (1687) ${ }^{511}$ and Keech $v$. \\ Sanford $(1734)^{512}$ predate the Judicature Act ${ }^{513}$ by less \\ than two hundred years. The term fiduciary itself only \\ found its modern use in the nineteenth century. ${ }^{514}$ Long \\ understood as amalgamated with the trust, ${ }^{515}$ fiduciary \\ liabilities have greatly expanded in the latter half \\ of the twentieth century. \\ Fiduciary duties can be found in agency, partner- \\ ships, guardianships, conservatorships, receiverships, \\ bailments, corporations, joint ventures, equitable \\ charges, security arrangements, venture capital, stra- \\ tegic alliances, franchising, and certain counseling \\ relations such as the attorney-client and doctor-

\footnotetext{
511 Walley $v$ Walley, 16871 Vern 484.

512 Keech $v$ Sandford, 1726 Sel Cas Ch 61, 25 ER 223. 1875 (UK), 38 \& 39 Vict, c 77 [together Judicature Act].

514 Sealy notes, that the term 'fiduciary' was uncommon and came into usage by way of textbook writers in the first half of the nineteenth century. See LS Sealy, "Fiduciary Relationships" (1962) 20:01 The Cambridge Law Journal 69 at 72 .

515 When the fiduciary concept was first developed in English courts, it was not distinguished terminologically from the concept of the trust. See ibid at 70 .
} \\ 513 Judicature Act, 1873 (UK), 36 \& 37 Vict, c 66; Judicature Act,
}


patient relationships, as well as in the roles of parents, educators, and clergymen, amongst others. ${ }^{516}$

This expansion is particularly noticeable in Canada. In 1988, the former Chief Justice of Australia, Sir Anthony Mason commented that "[a]ll Canada is divided into three parts: those who owe fiduciary duties, those to whom fiduciary duties are owed, and judges who keep creating new fiduciary duties!" Quoting that remark, MCEachern CJ of the Court of Appeal for British Columbia went on to observe:

Our Supreme Court of Canada has led the way in the common law world in extending fiduciary responsibilities and remedies but it has not provided as much guidance as it usually does in emerging areas of law. The law in this respect has been extended by our highest court not predictably or incrementally but in quantum leaps so that judges, lawyers and citizens alike are often unable to know whether a given situation is governed by the usual laws of contract, negligence or other torts, or by fiduciary obligations whose limits are difficult to discern. ${ }^{517}$

As those comments suggest, the expansion of fiduciary duties in Canada has given rise to significant criticism. Birks argues that "the fiduciary concept, in its current articulation, is a wholly illusory wrong, du-

\footnotetext{
516 Jerry W Markham, "Jerry W. Markham, Fiduciary Duties Under the Commodity Exchange Act" (1992) 68 Notre Dame L Rev 199 at 214. $517 A(C)$ V Critchley, (1998), 166 DLR (4th) 475 (CA) at 496, after quoting Chief Justice Mason.
} 
plicating the work of the ordinary law of tort." 518 To similar effect, John McCamus writes that the "new version of fiduciary doctrine has blurred the distinction between the domains of contract, tort and restitution or unjust enrichment." ${ }^{519}$ He goes on to conclude:

The recognition of new types of fiduciary obligations and the granting of damages as a form of relief for the breach of such duties has catapulted fiduciary obligation into a leadership role in doctrinal innovation and reform in the private law of obligations in Canadian common law. No longer confined to traditional notions of conflict of interest and profit-taking, fiduciary duties appear to be capable of expanding to include "disloyalty" in a much broader sense and, indeed, acts of incompetence. No longer confined to the traditional disgorgement remedies, fiduciary obligation now appears in the guise of a sort of freewheeling tort [...] an equitable kind of tort with respect to which common law constraints on tortious liability may or may not apply. It is, in this sense, a curious amalgam or blend of common law and equitable concepts. ${ }^{520}$

This indeterminacy is clear to the supreme court itself. Writing in Lac Minerals, Mr. Justice La Forest cautioned against resort to fiduciary language

[...] because of the view that certain remedies, deemed appropriate in the circumstances, would not be available unless a fiduciary relationship was present. In this sense, the label fiduciary imposes no obligations, but rather is merely instrumental or facilitative in achieving what appears to

\footnotetext{
518 Sealy, supra note 514 at 70.

519 JD McCamus, "The Evolving Role of Fiduciary Obligation" in Meredith Memorial Lectures 1998-1999 (Cowansville, Québec: Éditions Yvon Blais, 2000) at 209. 520 Ibid at 204 .
} 
be the appropriate result. ${ }^{521}$

Waters summarizes the state of the law as follows: "[i]t is undeniable that the concept of fiduciary relationship has been stretched in [certain] circumstances [...] to a degree where it has become meaningless [...]". ${ }^{522}$ What Waters refers to as "meaningless" is the appearance of justice alterity and indeterminacy at the highest levels of adjudication. The renaissance of Equity through the expansion of fiduciary obligations is accompanied by significant ambivalence.

As I have shown, the history of equity is marked by the negotiation of justice alterity, and in the case of fiduciary relations, justice indeterminacy. It is also a history of the sublation of legal subjectivity to achieve otherwise impossible forms of aggregate justice. Indeed, the intimation and manifestation of fiduciary obligations in areas where the "legal" is structurally disabled to recognize emancipatory claims may be inevitable in light of macro-normative failure. In short, the very proliferation of fiduciary relationships and the attendant criticism this has spawned attests to the justice alterity to which fiduciary re-

521 Lac minerals Ltd V International Corona Resources Ltd, [1989] 2 SCR 574 at 649 .

522 DWM Waters, ed, Waters' Law of Trusts in Canada, 3d ed (Toronto: Thomson Carswell, 2005) at 405 . 
lations seek proximity.

As Tamar Frankel has famously suggested, the advance of fiduciary duties in common law countries can be contextualized within a greater narrative through which status-based rights were eclipsed by contract, which is in turn eclipsed by the increased use of fiduciary obligations to encourage and generate mutual reliance. ${ }^{523}$ The shift from status to contract ${ }^{524}$ mirrored a concept of legitimacy based on an instrumentally calculating actor, the homo economicus, often associated with the works of John Stuart Mill. This atomized subject is focused on the rational maximization of wealth. Self-interest is his or her driving ethos, and to achieve this, a maximum of particularized wishes must be capable of enumeration.

The analysis of unavoidable epistemic thresholds in the previous chapter implies that free choice becomes inseparable from inalienable rights, and the ability to define and realize them with others who are likewise oriented. According to Amos:

The purpose of the Law of Contract is to impart stability and security to certain temporary relationships with one another which men spontaneously frame for themselves. The relationship between two contractors differs from the relationship of

523 See Frankel, supra note 336.

524 See generally, Maine, supra note 209. 
family life in the spontaneity which originates it, and in the freedom which the parties enjoy for the purpose either of describing and modifying its terms or of annulling it altogether. Thus the essential quality of the relationship implied in contract is freedom in respect of its original creation; in respect of the description of its nature and its terms; and in respect of the mode and period of its conclusion. The real policy which dictates a law of contract is that of giving the same reality and consistency to the groups which evolve themselves through the play of social and economic life as primitive law gives $[\ldots] \cdot{ }^{525}$

Oliver Wendell Holmes, a contemporary of Amos, wrote:

The duty to keep a contract at common law means a prediction that you must pay damages if you do not keep it - and nothing else. [...] But such a mode of looking at the matter stinks in the nostrils of those who think it advantageous to get as much ethics into the law as they can. ${ }^{526}$

As the complexity of society evolved this form of isolated self-interest contradicts the increasing need to depend or rely on others to exercise independent judgment or ensure outcomes in the pursuit of such interests.

In 1981, Jethro Lieberman began explicitly describing the rise of litigation as a method of realizing new forms of rights, ${ }^{527}$ and the consequential shift

525 Sheldon Amos, The Science of Law (Charleston, SC: Nabu Press, 2011) at 190 .

526 Holmes, supra note 24.

527 (1) Product liability (2) medical malpractice, (3) environmental issues, and (4) infringement of individual rights by public and private institutions. 
from contract to a fiduciary standard. ${ }^{528}$ Frankel has extensively explored this in numerous monographs and articles. ${ }^{529}$ She writes:

In our society, affluence is largely produced by interdependence, but personal freedom is cherished. Society's members turn to an arbitrator, the government, to obtain protection from personal coercion by those on whom they depend for specialized services. A fiduciary society attempts to maximize both the satisfaction of needs and the protection of freedom. [...] Unlike status and contract societies, a fiduciary society emphasizes not personal conflict and domination among individuals, but cooperation and identity of interest pursuant to acceptable but imposed standards. It permits the government to moderate between altruistic goals and individualistic, selfish desires, as well as between the social goal of increasing the common welfare and the individual desire to appropriate more than a "fair share."530

Frankel's position reflects a clear "fiduciarian" emphasis. David Hayton stresses the necessity for society to foster the capacity of individuals to be generous towards justice considerations. He writes, "[e]quity by promoting the ability of actors to legitimately choose to be a 'good man' [...] prevents a de528 See Jethro Koller Lieberman, The Litigious Society (New York: Basic Books, 1983) at 20 ("The course the law has taken may be denoted as a movement from contract to fiduciary, a phrase chosen deliberately to contrast with Sir Henry Maine's famous apothegm [...] that 'the movement of progressive societies has hitherto been a movement from status to contract." ").

529 In addition to "Fiduciary Law" supra note 303, Frankel's prolific output on these issues includes: Tamar Frankel, Fiduciary Law (Oxford; New York: Oxford University Press, 2011); Tamar Frankel, Fiduciary Law: Analysis, Definitions, Relationships, Duties, Remedies over History and Cultures (Anchorage, AK: Fathom, 2008); and, Tamar Frankel, "Fiduciary Duties as Default Rules" (1995) 74 Or L Rev 1209.

530 Frankel, supra note 336 at 801-02. 
fendant subjected to the fiduciary duty of loyalty from denying that he was a good man." ${ }^{531}$

Ernest Weinrib sees fiduciary obligations as a means by which legal categories of "stability and security" are maintained. He writes:

A sophisticated industrial and commercial society requires that its members be integrated rather than autonomously self-sufficient, and through the concepts of commercial and property law provides mechanisms of interaction and interdependence. The fiduciary obligation [...] constitutes a means by which those mechanisms are protected. ${ }^{532}$

At the same time, Weinrib notes the emerging "fiduciarian" focus: "[...] the notion of the high standard incumbent on a fiduciary has spread from its original homeland in the law of trusts and has subjected a diverse variety of entrepreneurs - directors, partners, agents, employees - to its colonizing sway."133

Despite fiduciary obligations being part of private legal ordering, they form a conduit to justice claims that are otherwise barred. These justice claims are normatively situated outside of the framework of private law and touch on over-arching questions normally associated with public policy without, however, being the product of statute. Finn writes:

531 Hayton, supra note 386 at 306.

532 Ernest J Weinrib, "The Fiduciary Obligation" (1975) 25:1 U Toronto LJ 1 at 11 .

533 Ibid at 1 . 
A fiduciary responsibility, ultimately, is an imposed not an accepted one [...]. The factors which lead to that imposition doubtless involve recognition of what the alleged fiduciary has agreed to do. But equally public policy considerations can ordain what he must do, whether this be agreed to or not. ${ }^{534}$

Deborah DeMott notes that, "[l]ike the giant panda, fiduciary obligation is difficult to classify and, unless one is willing to ignore various observed traits, arguably 'aberrant' however or wherever it is situated in a taxonomic scheme." 535

Miller insists that fiduciary obligations are a form of private law ordering, or even a subset of contract or unjust enrichment. ${ }^{536}$ But such a "legalist" position typically assumes that fiduciary relations are based on an implicit or constructive undertaking. Miller understands the recent Canadian Supreme Court case, Galambos, ${ }^{537}$ to reject

[t]he notion that a would-be beneficiary may establish a fiduciary relationship unilaterally. The faithfulness exacted of fiduciaries ought not to be capable of being commanded upon the whim, or even upon the reasonably founded trust, of beneficiaries. The idea of equal freedom that underlies private right entails that one cannot compel an-

534 Paul Finn, "The Fiduciary Principle" in T G Youdan, ed, Equity, Fiduciaries and Trusts (Toronto: Carswell, 1989) at 1.

535 DeMott, supra note 385 at 474.

536 Miller cites Frank H Easterbrook \& Daniel Fischel, "Contract and Fiduciary Duty" (1993) 36:1 JL \& Econ 425; Gareth Jones, "Unjust Enrichment and the Fiduciary's Duty of Loyalty"(1968) 84 Law Q Rev 472; and, Paul B Miller, "A Theory of Fiduciary Liability" (2010) 56 McGill L J 235 at 237.

537 Galambos $v$ Perez, 2009 SCC 48. 
other to serve his ends. ${ }^{538}$

Miller's position, amongst others who undertake to reprivatize equitable developments, ${ }^{539}$ constitutes a rearguard action designed to dull the significant impact that fiduciary development may have for the concept of "legal" agency.

The necessity for "legal" claims to be "imputable" to a legal subject is predicated upon the very notion of "free" agency that fiduciary indeterminacy excludes. ${ }^{540}$ Legalistic arguments aimed at fixing the

538 Miller, supra note 536 at 278 .

539 See Butler, $\mathrm{H}$ N \& Ribstein, L E, "Opting out of Fiduciary Duties: A Response to the Anti-Contractarians" (1990) 65 Wash L Rev 1 at 7 .

540 Free agency implies the absence of another's authority over the agent's action, whereas the fiduciary relationship implies continuous responsibility for and dependency upon another. It is the capacity to act that is perceived by the self to be unbound by any external authority. Free agency is the extension into the world of free will, and is ethically dependent on it. One can have free will, for example as the slave in the master-slave dialectic, but not be a free agent. Free agency comes to be affirmed within an economy of affirmation de-limited by convention and legacy subjectivity. The purportedly unbound quality of agency that is of service only to the free will in fact is revealed to be paradoxically - and invisibly to itself - determined by its subservience to norms as positive strictures and to the narrowed possible content of the will en-tailed by legacy subjectivity. As to free will, clark takes a position parallel to that of this thesis by noting that affirming free will inherently involves a set positions on underlying normative claims: "Free will engages us deeply because it seems central to our conception of who we are, our place in the world, and our moral intuitions. To take a position on whether we have free will, and what sort of freedom this is, is to take positions on a host of other fundamental and necessarily interlocking issues ... Free agency implies the absence of another's authority over the agent's action, whereas the fiduciary relationship implies continuous responsibility for and dependency upon another." See Thomas W Clark, "Fear Mechanism: A Compatibilist Critique of the "Volitional Brain'" in Keith Sutherland, Anthony Freeman \& Benjamin Libet, eds, The Volitional 
limits of fiduciary liabilities fail to grasp not only the historical essence of fiduciary claims but also their current role in normative evolution.

The expansion of fiduciary liability is a response to the failure of legal subjectivity and not an accessory to it. ${ }^{541}$ Fox-Decent writes that traditionally,

[p] ublic law encompasses the legal order established by the Constitution, statutes and international agreements. It may at any time supplement or replace altogether the common law regime of private law. Indeed, the story of the administrative state is largely the story of an attempt to dull the sharp edges of inequitable market forces regulated solely by private legal doctrines. ${ }^{542}$

I argue that through the expansion of fiduciary doctrines, we are witnessing a partial reversal of this narrative. In light of governance capture and the macro-normative failure of public law, emancipatory justice claims may be manifesting themselves in fiduciary relations, precisely because they are free of the limitations of both public and private law.

Rotman summarizes an understanding of the fiduciary that Frankel has championed:

Brain: Towards a Neuroscience of Free Will (Exeter, UK: Imprint Academic, 2004) 279.

541 D Gordon Smith, "The Critical Resource Theory of Fiduciary Duty" SSRN elibrary, online:

$<$ http://papers.ssrn.com/sol3/papers.cfm?abstract_id=339100>.

${ }^{542}$ Evan Fox-Decent, "The Fiduciary Nature of State Legal Authority" (2005) 31 Queen's LJ 259 at 282-83. 
Fiduciary law has its origins not only in equity but also in public policy. The creation of fiduciary doctrine may be traced to the need to protect the continued existence of certain types of relationships within a given society. Fiduciary law exists to preserve the integrity of socially valuable or necessary relationships that arise as a result of human interdependency. ${ }^{543}$

Finn concurs:

Fiduciary law [...] has been used, and is demonstrably used, to maintain the integrity, credibility and utility of relationships perceived to be of importance in a society. And it is used to protect interests, both personal and economic, which a society is perceived to deem valuable. ${ }^{544}$

The recognition of fiduciary duties attempts to internalize justice externalities within interdependent relationships. The equitable capacity to negotiate antinomical burdens may be a significant basis for social transformation. Furthermore, on the basis of the analysis offered in the previous chapter, a political attempt to produce or reproduce a legal economy of affirmation sufficient to internalize such justice claims would necessarily fail.

The recognition by the supreme court of fiduciary liabilities regarding macro-normative questions, such as towards Canada's aboriginal peoples, has had far-

\footnotetext{
543 Rotman, supra note 263 at 95. See also Jeffrey B Berryman et al, The Law of Trusts: A Contextual Approach, $2 \mathrm{~d}$ ed (Toronto: Emond Montgomery, 2008) at 742 . 544 Finn, supra note 534 at 26.
} 
reaching political implications. ${ }^{54}$ Thus, rather than interpreting cases like Galambos and Sharbern Holding Inc ${ }^{546}$ to imply the placement of sharp doctrinal constraints on the scope of the fiduciary duty, I would propose that the supreme court is understandably resisting the possibility that fiduciary obligations become decontextualized.

We have seen that finding a fiduciary relationship radically shifts legal burdens. Where this affects individuals of nominal means, fiduciary liability clearIy needs to be subject to reasonable and transparent limitations. However in cases like Elder Advocates ${ }^{547}$ we may be witnessing a new generation of litigation regarding macro-normative fiduciary obligations. ${ }^{548}$

\section{Macro vs. Micro-normative Fiduciary Adjudication}

A current trend to interpret public law generally, administrative law in particular, and the broad norms

\footnotetext{
545 See Guerin $V$ The Queen, [1984] 2 SCR 335; R V Sparrow, [1990] 1 SCR 1075 .

546 Sharbern Holding Inc V Vancouver Airport Centre Ltd, 2011 SCC 23 .

547 Alberta V Elder Advocates of Alberta Society, 2011 SCC 24. 548 Evan J Criddle "Fiduciary Administration: Rethinking Popular Representation in Agency Rulemaking" (2008) 88 Tex L Rev 441 at 443-49; Evan J Criddle, "Fiduciary Foundations of Administrative Law" (2006)54 UCLA L Rev 117 at 120-23; Evan J Criddle \& Evan Fox-Decent, "A Fiduciary Theory of Jus Cogens" (2009) 34 Yale J Int'l L 331; David L Ponet \& Ethan J Leib, "Fiduciary Law's Lessons For Deliberative Democracy" (2009) 34 Yale J Int'l L 331.
} 
of jus cogens using fiduciary concepts is inspired by the need to open macro-normative questions to justice alterity. Fox-Decent asserts that

[...] in the public law setting, the fiduciary duty of loyalty may assume the content of public law duties of fairness and reasonableness. Moreover, I argue that in its most fundamental and general form, the fiduciary obligation is an obligation to exercise fiduciary power exclusively for the sake of the other regarding purposes for which it is held or conferred. ${ }^{549}$

Ponet and Leib argue in addition that the

thinking of public officials as fiduciaries is not only an historical inheritance but is also indicated by functional and structural considerations of the relationship between ruler and ruled. A distinctive feature of the fiduciary relationship - the inequality and asymmetry between fiduciary and beneficiary - maps well onto the relationship between rulers and ruled. The inequality and asymmetry within the relationship usually flows from the fiduciary's possession of greater expertise or greater information than the beneficiary, leaving the beneficiary vulnerable to the fiduciary's predation. ${ }^{550}$

\footnotetext{
549 Fox-Decent, supra note 542 at 259.

550 Ponet \& Leib, supra note 516 at 1255. Despite being in principle sympathetic to the cause of deliberative democracy, Ponet and Leib are caught up in a comparable "legalist" dilemma. They write, "The duty of loyalty creates an affirmative incentive on the part of the ruler to deliberatively engage constituents; only through dialogue and exchange is the elected fiduciary shielded from the charge that she acted after her own private good or the good of her funding patrons rather than the public good dictated by her office. The duty of loyalty creates an affirmative incentive on the part of the ruler to deliberatively engage constituents; only through dialogue and exchange is the elected fiduciary shielded from the charge that she acted after her own private good or the good of her funding patrons rather than the public good dictated by her office." See ibid at 1258. Ponet and Leib do not acknowledge the extent to which fiduciary duties can by definition explicitly distance the fiduciary from the influence of the beneficiary. The fiduciary in an agency relationship is not the same as fiduciary in a trust. Ponet and Leib also stress the vulnerability of the ruled to the superiority of democratically
} 
Fox-Decent concludes:

Simply put, the upshot of conceiving of the state as fiduciary is that everyone subject to state power -regardless of civil or political status is a beneficiary of an overarching fiduciary obligation that manifests itself as the rule of law. The state's conformity to the rule of law gives us a reason to fulfill our legal obligations. ${ }^{551}$

Yet, as Humphrey summarizes, the concept of the "rule of law" is not without contradictions:

The rule of law in a given context, [...] may condone or underpin poverty, violence, or ignorance. [...] [H] owever, reference to the "rule" of law is apparently thought to supply some extra ingredient, injecting some quality into law, or denoting a particular configuration of law, that insures against these outcomes. ${ }^{552}$

Raz has pointed out that "a non-democratic legal system, based on denial of human rights (and) on extensive poverty [...] may in principle, conform to the requirements of the rule of law better than any of the [...] Western democracies." 553 And Sinclair observes:

The idea of the rule of law is negative in two senses. First, conformity to it does not cause good except through avoiding evil and, secondly, the evil which is avoided, could only be caused by law itself. It is crucial for Raz that the rule of law does not become confused with the rule of the good law: a non democratic legal

elected. Almost all commentators are unified in the assertion that vulnerability alone does not form a strong basis for the attachment of fiduciary obligations.

551 Fox-Decent, supra note 542 at 261.

552 Stephen Humphreys, Theatre of the Rule of Law: Transnational Legal Intervention in Theory and Practice (Cambridge, UK: Cambridge University Press, 2010) at 3 .

553 Raz, supra note 106 at 291. 
system based on denial of human rights, racial segregation, sexual inequalities and religious persecution may very well conform to the rule of law. The rule of law does not a good legal system make. It is conformity that is assessed, not content or consequence. The rule of law is principally concerned with the form of law, rather than its content: laws must not impose impossible demands, they should be prospective, not retroactive; laws should be consistent with each other; they should be public, clear and constant over time: Provided a law meets the checklist of requirements its content is unimportant. The belief in the rectitude of governance of laws, not men, has long been considered the mark of a civilized society. The idea of the rule of law retains a powerful resonance in today's society and the common sense of law bears its imprint. ${ }^{554}$

Fox-Decent's model flows from a conception of legal subjectivity that is predicated on the continuity of self-regarding behaviour. However, this approach to perfecting the "legal" by making it accountable to a fiduciary standard is paradoxical. On the one hand, as Fox-Decent writes:

There are advantages, however, to adopting a conception of the rule of law that treats legal norms and standards as intrinsically valuable, and as independent of the particular social goals or policies they may try to secure. If legal norms can be shown to have intrinsic and autonomous value, their authority needs no further justification in terms of some greater good or political ideal. On this view, legal norms are independently valuable, and within that value we find the moral basis of the state's legal authority, as well as the subject's duty to obey the

554 Adriana Sinclair, International Relations Theory and International Law: A Critical Approach (Cambridge, UK: Cambridge University Press, 2010) at 47 . 
law. ${ }^{555}$

This mirrors the intrinsic emancipatory claim explored in the section on positive law. On the other hand, Fox-Decent puts an aspirational limit on this intrinsic affirmation:

Further, if the reason why the rule of law enjoys independent moral authority is that it rests on an overarching state-subject fiduciary relationship, then the legislature will be limited in the sorts of laws it can legitimately enact. As fiduciary, the legislature cannot pass laws that violate its fiduciary duties without at the same time violating the rule of law. ${ }^{556}$

This fiduciary check on the intrinsic claim juxtaposes it with a radical alterity which Fox-Decent's concept of the "rule of law" excludes.

State legitimacy is predicated upon the ability to realize on the fiduciary claim vis-à-vis its discretion over its citizens. Fox-Decent writes:

But more important than enforcement mechanisms is the fidelity to law that the state can demand in virtue of the legitimacy of its legal authority. Because the state as fiduciary owes an impartial duty of loyalty to those within its jurisdiction, it has a moral argument on which to base its claim to legal authority, and in return (other things being equal) it can expect allegiance to its

555 Evan Fox-Decent, Sovereignty's Promise: The State as Fiduciary (Oxford: Oxford University Press, 2011) at 39.

556 Fox-Decent, supra note 542 at 271.

557 Ibid. 
Fox-Decent goes on to assert that the fiduciary takes up the agency for the legal personality of the beneficiary. The fiduciary, on this reading, perfects the beneficiary's legal capacity, and does so in order to fulfill the requirement of respecting the other's innate moral capacity. Fox-Decent concludes:

On this understanding of personality, we can explain the duties of the modern fiduciary only if we assume that the beneficiary's entrusted interests are embodiments of her legal personality, and therefore immune to the fiduciary's appropriation. [...] But the nature of the other regarding obligation that attends an exercise of fiduciary power, as in the parent-child case, remains explicable in terms of the beneficiary's innate moral capacity to place the fiduciary under obligation. ${ }^{558}$

Fox-Decent, while asserting a normative unavoidability, does not draw out its epistemic prerequisites. Because of this lacuna, we are left with the reification of the "legal" person embodying fiduciary interests.

However, to say that fiduciary duties find their consummation in the expression of sui generis "legal" rights does not pay heed to the evolution of the fiduciary in relation to justice alterity and indeterminacy. Fox-Decent indirectly acknowledges this when he writes:

558 Ibid at 280. 
The idea of personality also explains why the fiduciary duty can be characterized at such a high level of abstraction, independent of any particular purpose. Personality denotes a capacity for purposive action, but it does not denote any particular purpose or action per se. Thus, rightful exercises of fiduciary power, in principle, may attempt to satisfy any lawful purpose so long as the purpose is other-regarding in the sense that it respects the demands made by the beneficiary's personality within a regime of equal freedom. ${ }^{559}$

The indeterminacy affirmed here does not yet give an account of justice alterity that sublates legal personality.

Assuming that public fiduciary liability predicated upon the rule of law could be implemented, FoxDecent's model does not in itself promote transformation or the enabling of individuals beyond the limits of their (legal) subjectivity. Although he resolutely defends an expansive view of fiduciary obligations, Fox-Decent's agnostic position regarding justice indeterminacy is in the end parallel to that underlying the legalistic critique of fiduciary obligations. Put differently, his unqualified egalitarian affirmation of justice alterity leads to the risk of aleatoric justice claims being mapped uncritically onto the emancipatory.

559 Ibid. 
Emancipatory claims reflect immutable, incommensurable, and changing justice intuitions, which cannot be fixed and are never "satisfied" or exhausted. PureIy emancipatory claims are the embodiment of pure extrinsic equity. The resourcing of the scope of such claims always risks disappointment ${ }^{0 / 1}$, and places a disproportionate stress on epistemic and justice resources. The unrestricted enabling of emancipatory claims is humanly unsustainable, if theoretically necessary. And yet, emancipatory claims are a normative unavoidability because they reflect, to use Adornian terminology, an intersection of the epistemic and justice non-identical.

As we explored in the section on Adorno, the concept of the non-identical is continuously present, and marks the inadequacy of any justice affirmation. The scope and meaning of this inadequacy can never be entirely transparent in the moment of its articulation. Consequently, the non-identical, as perceived in the emancipatory claim, may be more critical than any other justice perception.

We need only think of ideologies, whether socialist, fascist, or capitalist, that undertook to deliver on eudaemonic thresholds - that is, on their own in- 
trinsic affirmations of the good. ${ }^{560}$ None of these ideologies could or can have their inadequacies overcome by using the logic of justice intrinsic to them, no matter what their macro-justice failures may be.

The non-identical expressed through the emancipatory claim has the potential to delegitimate any normative order (at the risk of its unsustainability). Fiduciary indeterminacy limits the scope of emancipatory claims to those that have some measure of anchoring in the justice claims of legacy subjectivity, without at the same time reifying them - unless, of course, legalism sets in.

Fiduciary obligations that take up the extrinsic pole of equity, typically expressed in prescriptive duties and an aspirational standard of care, can go well beyond any limits that would be set by an imputed legal agency or contingent status of the beneficiary. In this regard it is notable that some fiduciary duties are focussed on enabling the transformation of the status or agency of the beneficiary.

\footnotetext{
560 Throughout the thesis I highlight how various forms of legal reasoning have an emancipatory core, which is explicitly or implicitly driven by emancipatory and eudaemonic considerations. Solidarity in and of itself, as a macro-normative category cannot exceed its structural limitations.
} 
Unlike pure emancipatory claims, even the most extrinsic of fiduciary orientations must work with the contingent identity of the beneficiary, although the goal may be to exceed its limits. Whereas emancipatory claims cannot recognize the justice claims of the "human, all-to-human", ${ }^{561}$ as they already reflect limitations to be overcome, extrinsic fiduciary enabling straddles both legacy subjectivity and emancipatory claims. Fiduciary obligations also mirror this on a structural level. Because fiduciary obligations draw on extrinsic equitable impulses, they are able to animate over-arching, trans-subjective justice claims, while still maintaining a tension with justice indeterminacy. In this sense, fiduciary obligations are structurally enabled to produce the locus of legitimacy in the manner that Criddle and Fox-Decent are seeking to affirm. ${ }^{562}$

\footnotetext{
561 Nietzsche, writing on "The advantages of psychological observation" observed that "meditating on things human, all too human (or, as the learned phrase goes, 'psychological observation') is one of the means by which man can ease life's burden; [...] by exercising this art, one can secure presence of mind in difficult situations and entertainment amid boring surroundings; indeed, [...] from the thorniest and unhappiest phases of one's own life one can pluck maxims and feel a bit better thereby: this was believed, known - in earlier centuries. Friedrich Wilhelm Nietzsche, Human, All Too Human: A Book for Free Spirits, translated by Marion Faber (Lincoln, NE: University of Nebraska Press, 1996).

562 "The basic insight of this Article is that administrative law's metaphorical fiduciary foundations can no longer be dismissed as mere rhetoric; rather, public law increasingly draws upon fiduci-
} 
Obligating those exercising discretion to be accountable to justice indeterminacy is the emancipatory outcome that Criddle and Fox-Decent are both embracing and delimiting at the same time. Their juxtaposition of fiduciary duties with public law embraces, without calling it as such, a negotiation of justice antinomies.

At the same time, the limited perfectibility of the beneficiary as a legal subject partially negates justice alterity. Public fiduciary regimes unable to respond to antinomical burdens that surpass the reproduction of legal subjectivity are incapable of substantive transformation. Such a delimited "fiduciary" regime would join the long list of eschatological models claiming to have found the method for overcoming the need for emancipatory claims.

A fiduciary implosion along these lines could arise as follows. Once a state has fulfilled the unavoidable task of providing a fiduciary response to existing "legal" agency, i.e. agency as confined by the legal order's understanding of (objective) beneficiary rights, needs and interests, there can be no reason

ary law's three foundational elements as a conceptual framework for constraining agency discretion and mediating relationships between the executive, legislative, and judicial branches." See Evan J Criddle, supra note 548 at 120. 
for the state's legitimacy to be called into question. ${ }^{563}$

Within an economy of affirmation, all forms of subjectivity that are non-identical with recognized "legal" identity are normatively marginalized if not excluded. If in fact the state's fiduciary role is to facilitate the legal subjectivity of citizens within the confines of their own consciousness or a comparable constructive one, then there would no opposition to, for example, ecocidal collective irrationalism, as long as it conformed to the "legitimate" reproduction of legacy subjectivity.

Without the ability to trace and develop the relationship among emancipatory claims, justice indeterminacy, and justice alterity, any resources placed in meeting antinomical burdens through a legalistic public fiduciary duty will be wasted. The "rule of law" relied upon here, despite being a justice unavoidability, cannot adequately engage the challenges posed by justice alterity, let alone the indeterminacy of fidu-

563 In the Soviet Union, those who were unwilling to accept the legitimacy of a self-understood fiduciary state were relegated to the psychiatric wards. See Peter Reddaway \& Sidney Bloch, Soviet Psychiatric Abuse: The Shadow Over World Psychiatry (Boulder, Co10: Westview Press, 1985). 
ciary relations or the full gamut of emancipatory claims .

Assuming that that Criddle and Fox-Decent's primary intuition is valid, i.e. that the antinomical capacity of the fiduciary must be brought to bear on macro-normative questions, what would this look like in light of the theoretical explorations undertaken here? A macro-normative shift comparable to universal suffrage or the Thirteenth Amendment previously mentioned contemplates the evolution of further justice unavoidabilities.

An other-regarding macro-normative transformation cannot depend on an apotheosis of individualized selfregarding through an amalgamation of ethical egoism, rational egoism, and contractual egoism. As I have shown, a macro-normative transformation has implications for minimum "legitimate" epistemic thresholds. Adorno's moral and normative model obliges us to subject epistemic presumptions to an additional measure of justice alterity analysis (the non-identical) beyond their capacity for absorption into our economy of affirmation. If we adopt such a position vis-à-vis the concept of "legal" subjectivity, we can map otherregarding fiduciary relations in public law. The nor- 
mative dimension of Adorno's concept of the nonidentical carries with it the obligation to achieve a more differentiated justice aggregate. Adorno's epistemic transformation has direct implications for macro-normative legitimacy.

The locus of such transformation is difficult to affirm with any certainty. The political process is dependent on satisfying a collection of heterogeneous, and to some degree, fungible knowable interests. It is structurally designed to represent interests that, to one degree or another, are those of the majority of a proximate constituency. There is no reason to impute to the (mass democratic) political process the willingness or capacity to resource a normative/epistemic transformation premised on the substantive shift in the economy of affirmation of its constituents.

Private legal (economic) ordering is by definition too diverse, individualized, and fragmented to coalesce into a coherent self-sublating sustainable normative order. ${ }^{564}$ The emancipation of some at some

564 Emancipatory claims of the kind that would create sustainability in the face of macro-failures that impact on our survival are fully outside the framework of private ordering per se. There are no equally represented actors, no consideration, and there is no locus for the embrace of justice alterity or indeterminacy. If we presume that private ordering needs to address an overlap of largely identifiable and existing claims, there is no argument to assert that it can be the source of self-sublation. 
point in time does not constitute a macro-normative shift. Furthermore, the judiciary is disabled from affirming justice alterity at the peril of its own selfunderstanding and legitimacy.

Finally, even radical macro-transformation that would seek emancipation at the expense of the justice unavoidabilities, explored in the analysis of law and equity, engenders the fateful hazard of imploding under the burden of disappointment ${ }^{0 / 1}$. Consequently there is no unique emancipatory agency to shoulder accountability for enabling an other-regarding outcome of the kind implied here.

This conclusion is not as dire as it seems. By recognizing that certain epistemic/justice thresholds are lost at the peril of the totality, we are reminded of a trope immanent to fiduciary liability. Without the capacity to resource and reproduce a fiduciary liability to the justice claims associated with legacy subjectivity, including those justice unavoidabilities and interdependent epistemic thresholds explored here, any macro-normative transformation will collapse.

As the most radical instance of equity, fiduciary relations can embody an unparalleled antinomical capacity. If we could conceive of macro-normative fidu- 
ciary liability as not limited to individuals or classes of individuals, but always also to other-regarding justice/epistemic thresholds, we could develop fiduciary liabilities to justice indeterminacies such as ecological boundaries to the economy. Using such a differentiated fiduciary doctrine as the locus for macro-normative transformation is I argue almost imperative to our circumstances.

\section{Supreme Court Case Law}

The analysis of Criddle and Fox-Decent's model of a fiduciary duty oriented to the legal agency of citizens revealed the unfeasibility of identifying a generalized beneficiary. The supreme court of Canada has rightly refused to recognize the possibility of adjudicating such obligations. ${ }^{565}$ At the same time the Court's effort to refract duties to produce macronormative outcomes (although it would not characterize them as such) fails to articulate core aspects of fiduciary justice, let alone respond to the challenges of macro-normative transformation.

565 See the analysis of Elder Advocates of Alberta Society $V$ Alberta, 2009 ABCA 403, below. 
I explore these themes by analysing two important cases notably with a view to outlining both what has been achieved and what remains unfulfilled in the fiduciary conception still being developed by our highest court. These two cases focus on public fiduciary loyalty and thus have a clear connection to macronormative outcomes.

However, I do not mean to suggest through these examples that the burden of macro-normative transformation reposes only on state actors. A broader investigation of the macro-normative significance of fiduciary duties in other contexts - corporate, professional, familial - lies beyond the scope of this thesis.

\section{Guerin}

There are two ways in which Guerin is central to an analysis of the macro-normative implications of fiduciary relationships. The court analyzes (i) the indeterminate and sui generis nature of aboriginal land claims and property rights; and (ii) the imposition of the Crown's fiduciary duty in protection of them. I argue that the invocation of a fiduciary relationship 
is a consequence of valuing and resourcing justice indeterminacy

Guerin $^{566}$ involved the surrender ${ }^{567}$ of land from the Musqueam Indian Band to the Crown pursuant to the terms of s. 18 of the Indian Act. That surrender was made for the purposes of allowing the crown to enter into a lease for the benefit of the Musqueam. The Band signed a document that gave the government unrestricted discretion regarding the choice of lessee and any conditions of the lease. It also provided oral instructions on the conditions it desired. The government entered into a lease with a golf club, without subsequent consultation, which was worth significantly less than the Musqueam had expected.

The Musqueam Band's action for breach of trust prevailed at trial but was reversed on appeal. In its historic decision, the supreme court affirmed the fiduciary duty of the Crown, and explored the complex of

566 Guerin $V$ The Queen, supra note 545.

567 See ibid at 376 per Dickson J ("An Indian Band is prohibited from directly transferring its interest to a third party. Any sale or lease of land can only be carried out after a surrender has taken place, with the crown then acting on the Band's behalf. The crown first took this responsibility upon itself in the Royal Proclamation of 1763. It is still recognized in the surrender provisions of the Indian Act. The surrender requirement, and the responsibility it entails, are the source of a distinct fiduciary obligation owed by the Crown to the Indians. In order to explore the character of this obligation, however, it is first necessary to consider the basis of aboriginal title and the nature of the interest in land which it represents."). 
indeterminate justice claims that First Nations have sui generis and as against the Crown.

Both levels of the plurality $\mathrm{s}^{568}$ decision ultimately decline to find a pre-surrender relationship of trust for the benefit of the Musqueam Indian Band. For Wilson $J$, in contrast, "the fiduciary duty which existed at large under the section to hold the land in the reserve for the use and benefit of the Band crystallized upon the surrender into an express trust of specific land for a specific purpose."569 Dickson J finds that,

[...] the nature of Indian title and the framework of the statutory scheme established for disposing of Indian land places upon the crown an equitable obligation, enforceable by the courts, to deal

568 Beetz, Chouinard, and Lamer Dickson J concur in the decision of Dickson $J$ (as he then was). Ritchie and McIntyre JJ concur in the decision of Wilson $J$. Estey $J^{\prime}$ s separate reasons argue in the alternative, that the "Crown becomes the appointed agent of the Indians to develop and exploit, under the direction of the Indians and for their benefit, the usufructuary interest." Estey J hesitates "to resort to the more technical and far-reaching doctrines of the law of trusts and the concomitant law attaching to the fiduciary." See ibid at 395-6. Estey J does not explore the role of fiduciary obligations in agency, despite the fact that his agency analysis reaches the same conclusion on the facts. I am not convinced that all nuances of the Crown's obligations are reflected in the concept of agency. Estey $J$ is offering a more restrictive reading of the Crown's obligations than either Wilson or Dickson Ju. The desire to make the crown more narrowly accountable has the effect of limiting its liability primarily to proscriptive duties. Wilson and Dickson JJ concur in finding of a significantly more prescriptive role for the Crown, making reference as they do to statute, the complexity of the history of the Aboriginal peoples, and to the specific facts of the case. In order to reflect the court's over-arching consensus on crown fiduciary duties, I mean my analysis to include the implicit fiduciary elements of Estey J's opinion. 569 Ibid at 355 . 
with the land for the benefit of the Indians. This obligation does not amount to a trust in the private law sense. It is rather a fiduciary duty. If, however, the crown breaches this fiduciary duty it will be liable to the Indians in the same way and to the same extent as if such a trust were in effect. ${ }^{570}$

The Supreme Court's oscillation between trust, fiduciary, and agency underscores the antinomical characteristic of aboriginal land title.

Wilson J cites Lord Watson in St. Catherine's Milling and Lumber Co. $V$ The Queen ${ }^{571}$ in defining "the tenure of the Indians [...] [as] a personal and usufructuary right". ${ }^{572}$ She goes on to say that Indian Bands "have a beneficial interest in their reserves and that the crown has a responsibility to protect that interest and make sure that any purpose to which reserve land is put will not interfere with it." 573

Dickson $J$ delves further into the murkiness of aboriginal title, citing Johnson $V M^{\prime} I n t o s h^{574}$ to support the finding that Aboriginal title relies on the Proclamation of 1763, but also "that rights of Indians in the lands they traditionally occupied prior to Eu-

\footnotetext{
570 Ibid at 376 .

571 St Catherine's Milling and Lumber Co $V$ The Queen (1888) 14 App Cas 46 (PC).

572 Guerin $V$ The Queen, supra note 513 at 349 (Affirmed in Smith $V$ The Queen [1983] 1 SCR 554.

573 Guerin $V$ The Queen, supra note 545 at 349.

574 Johnson $V M^{\prime}$ Intosh, 182321 US 543, 5 L Ed 681, 8 wheat 543.
} 
ropean colonization both predated and survived the claims to sovereignty made by various European nations $[\ldots]^{\prime \prime} .575$

He goes on to write that the "principle of discovery [...] gave the ultimate title in the land in a particular area to the nation which had discovered and claimed it."576 This principle is defined by Marshall CJ as follows:

The exclusion of all other Europeans, necessarily gave to the nation making the discovery the sole right of acquiring the soil from the natives, and establishing settlements upon it. It was a right with which no Europeans would interfere. It was a right which all asserted for themselves, and to the assertion of which, by others, all assented.

$[\ldots]$

In the establishment of these relations, the rights of the original inhabitants were, in no instance, entirely disregarded; but were necessarily, to a considerable extent, impaired. They were admitted to be the rightful occupants of the soil, with a legal as well as just claim to retain possession of it, and to use it according to their own discretion; but their rights to complete sovereignty, as independent nations, were necessarily diminished, and their power to dispose of the soil at their own will, to whomsoever they pleased, was denied by the original fundamental principle, that discovery gave exclusive title to those who made it. ${ }^{577}$

Dickson $J$ underscores the continuity of presumptive title with reference to the Privy Council's decision

575 Guerin $v$ The Queen, supra note 545 at 377-8.

576 Ibid at 378 [emphasis added].

577 Johnson $V$ M'Intosh, supra note 574 at 573-4. 
in Amodu Tijani v. Southern Nigeria,"578 as "an independent legal right which, although recognized by the Royal Proclamation of 1763, nonetheless predates it." 579 The Supreme Court of Canada made a parallel affirmation in Calder v. Attorney General of British CoI umbia. ${ }^{580}$

My analysis of the Court's reasoning in Guerin will leave aside the logical inadequacy of grounding the normative legitimacy of an outcome in its facticity. However, the concept of "ultimate title" based on the barring of competing claims would rely on exclusion of the aboriginal rights to support sovereignty. By this logic the crown must have and maintain exclusive prerogative for the survival of its "sole right"

However, aboriginal peoples have a personal and usufructuary right, a legal right of possession and use at their discretion. If aboriginal peoples have rights, these must be legally enforceable as against the Crown. If the Crown bases its sovereignty on defacto exclusion of competing claims, we are confronted by an antinomy. This is particularly the case if such

578 Amodu Tijani $v$ Southern Nigeria (Secretary), [1921] 2 AC 399.

579 Guerin $V$ The Queen, supra note 545 at 378.

580 Calder $v$ British Columbia (AG), [1973] SCR 313. 
claims admittedly predate any normative prerogative claimed by the crown.

This antinomy first takes the form of mutually exclusive propositions ex ante, i.e. either the crown succeeds in excluding of aboriginal rights, or the aboriginal peoples' rights extinguish Crown sovereignty. In addition, it poses the problem of what these antinomical positions mean for the law on an ongoing basis.

Aboriginal peoples" "legal as well as just claim to retain possession of [aboriginal land], and to use it according to their own discretion" ${ }^{581}$ is iteratively oppositional to the establishment of defined entitlements on those territories that could interfere with those rights, and thus by definition gives rise to indeterminacy

To have the right to use something at one's discretion, using the logic of the Crown's sovereignty, must mean the exclusion of competing claims. It must also mean that these rights are subject to variance at will. Simultaneously to circumscribe this right by a prohibition against alienation installs the crown as

581 Johnson $V M^{\prime}$ Intosh, supra note 574 at 21 [emphasis added]. 
the authority that must ensure that aboriginal peoples are not subject to the Crown's own exclusionary logic.

In short, aboriginal title, as relied upon and protected by the Crown, is both antinomical and indeterminate. It draws upon, and at the same time negates the legal categories of title and right. Dickson J writes:

As was pointed out earlier, the Indians' interest in land is an independent legal interest. It is not a creation of either the legislative or executive branches of government. The Crown's obligation to the Indians with respect to that interest is therefore not a public law duty. While it is not a private law duty in the strict sense either, it is nonetheless in the nature of a private law duty. Therefore, in this sui generis relationship, it is not improper to regard the Crown as a fiduciary. ${ }^{582}$

In chapter three on Equity, up to and including the rise of fiduciary obligations, we observed the efforts to seek justice outcomes through the sublation of legal subjectivity.

In Guerin we see the supreme court maintain and negate the legal agency of the crown and of aboriginal peoples. The Crown, despite its "ultimate title", is held to a fiduciary standard in order "to protect and preserve the Bands' interests from invasion or de-

582 Guerin $V$ The Queen, supra note 545 at 385. 
struction."583 At the same time, the discretionary exercise of aboriginal title is rendered dependent upon the Crown.

I assert that it is contradictory to maintain the notion of the Crown as "fiduciary" when Aboriginal title is understood as "a mere qualification of or burden on the radical or final title of the Sovereign". ${ }^{54}$ As Dickson J makes clear:

Indians have a legal right to occupy and possess certain lands, the ultimate title to which is in the crown. While their interest does not, strictly speaking, amount to beneficial ownership, neither is its nature completely exhausted by the concept of a personal right. It is true that the sui generis interest which the Indians have in the land is personal in the sense that it cannot be transferred to a grantee, but it is also true, as will presently appear, that the interest gives rise upon surrender to a distinctive fiduciary obligation on the part of the crown to deal with the land for the benefit of the surrendering Indians. These two aspects of Indian title go together, since the Crown's original purpose in declaring the Indians' interest to be inalienable otherwise than to the crown was to facilitate the crown's ability to represent the Indians in dealings with third parties. ${ }^{585}$

The thresholds of other-regard and loyalty to be attained in the Crown's fiduciary relationship to aboriginal title force the crown into an equitable em-

583 Ibid at 350 per Wilson J.

584 Amodu Tijani $v$ Southern Nigeria (Secretary), supra note 578 at 403 .

585 Guerin $V$ The Queen, supra note 545 at 382. 
brace of justice alterity to its own stated legitimate source of sovereignty.

The non-transferable quality of sui generis aboriginal title makes aboriginal peoples equally alien to conventional legal agency. This is presented as an example "of the necessity for getting rid of the assumption that the ownership of land naturally breaks itself up into estates, conceived as creatures of inherent legal principle." 586

A signifcant and remarkable feature of Guerin is the discussion of aboriginal title and Crown duties before and after the surrender of the lands in question. For both Wilson and Dickson JJ, the moment of surrender crystallizes Crown duties. Yet if we recall the earlier argument that exclusivity is the basis for prerogative, we encounter a further layer of antinomy.

In Guerin, when the Musqueam Band surrendered all discretion, the Crown became subject to an even greater other-regarding burden. Whether in addition to the fiduciary duty, the crown becomes a trustee, and/or agent is inversely proportional to the degree of discretion that the Crown is understood to exercise.

\footnotetext{
586 Amodu Tijani $v$ Southern Nigeria (Secretary), supra note 578 at 403 .
} 
Unrestricted Crown prerogative is shadowed by aboriginal vulnerability and an expansion in the normative regimes to enforce the Crown's burden to become and be other-regarding. As Dickson J writes,

Parliament has conferred upon the crown a discretion to decide for itself where the Indians' best interests really lie. This is the effect of $\mathrm{s}$. 18 (1) of the Act. This discretion on the part of the Crown, far from ousting, as the Crown contends, the jurisdiction of the courts to regulate the relationship between the crown and the Indians, has the effect of transforming the crown's obligation into a fiduciary one. ${ }^{587}$

Dickson J cites Weinrib to explain that

[where there is a fiduciary obligation] there is a relation in which the principal's interests can be affected by, and are therefore dependent on, the manner in which the fiduciary uses the discretion which has been delegated to him. The fiduciary obligation is the law's blunt tool for the control of this discretion. ${ }^{588}$

Dickson J continues,

where by statute, agreement, or perhaps by unilateral undertaking, one party has an obligation to act for the benefit of another, and that obligation carries with it a discretionary power, the party thus empowered becomes a fiduciary. Equity will then supervise the relationship by holding him to the fiduciary's strict standard of conduct. ${ }^{589}$

In summary, Guerin embraces a shifting constellational analysis of antinomical legal concepts, which become more indeterminate in equity the more legal rights

587 Guerin V The Queen, supra note 545 at 384.

588 Weinrib, supra note 532 at 7.

589 Guerin $V$ The Queen, supra note 545 at 384 . 
concretize.

The scope of possible other-regarding relationships between the crown and aboriginal peoples explored in Guerin indicates the impossibility of resolving and fixing the shifting and indeterminate nature of their mutual obligations. As I have tried briefly to demonstrate, the supreme court has responded to any increase in the degree of legal prerogative with the imposition of far reaching fiduciary obligations, both in Guerin and in subsequent cases. ${ }^{590}$

Guerin defined the "unique" fiduciary duty owed to aboriginal peoples. The Court's language, despite asserting a sui generis categorization, oscillates between private and public law conceptualizations. ${ }^{591}$ The

\footnotetext{
590 It is beyond the scope of the thesis to do a full analysis of the subsequent cases on the Crown's fiduciary duty to aboriginal peoples. Significant cases include $R \mathrm{~V}$ Sparrow, supra note 513; $R$ V Van der Peet, [1996] 2 SCR 507; Delgamuukw v British Columbia, [1997] 3 SCR 1010; Osoyoos Indian Band V Oliver (Town), 2001 SCC 85; and, Ermineskin Indian Band and Nation V Canada, 2009 SCC 9. Useful commentaries include: Michael Coyle, "Loyalty and Distinctiveness: A New Approach to the Crown's Fiduciary Duty toward Aboriginal Peoples" (2002) 40 Alta L Rev 841; Michael Bryant, "Crown-Aboriginal Relationships in Canada: The Phantom of Fiduciary Law" (1993) 27 UBC L Rev 19; Leonard Ian Rotman, "CrownNative Relations as Fiduciary: Reflections Almost Twenty Years After Guerin" (2003) 22 Windsor YB Access Just 363; Paul Finn, "Public Trusts, Public Fiduciaries" (2010) 38 Fed L Rev 335; Eric Reiter, "Fact, Narrative, and the Judicial Uses of History: Delgamuukw and Beyond" (2010) 2010 Indigenous LJ 55.

591 See Guerin $V$ The Queen, supra note 545 at 385 ("[...]obligation [...] that is therefore not a public law duty. While it is not a private law duty in the strict sense either, it is nonetheless in the nature of a private law duty. Therefore, in this sui generis relationship, it is not improper to regard the Crown as a fiduciary.") .
} 
duty is grounded by "analogy" to private law. In Wewaykum, the court affirms that the fiduciary duty owed is not restricted to instances where the facts raise "considerations 'in the nature of a private law duty'".592 In Sparrow, ${ }^{593}$ the court grounds the fiduciary duty in the "historic powers of responsibility assumed by the Crown. [...] The relationship between the Government and aboriginals is trust-like, rather than adversarial $[\ldots] . "{ }^{\prime 594}$

I argue that the appearance in Guerin of fiduciary obligations is the only possible response to the antinomical justice burdens that exist between the Crown and aboriginal peoples. The fiduciary relationship necessarily binds the resources of all participants outside the scope of immediately identifiable needs. The fiduciary relationship here represents disparate justice claims, and is the means by which an otherness-as-relationship is maintained in a requisite tension

Thus, legal recognition of the fiduciary form comes closest to a methodology that would preserve the differentiation of incommensurable claims at the ex-

Ibid at 337.

$R$ V Sparrow, supra note 590.

Ibid. 
pense of formally delimited law. It is a kind of productive paradox within the law, but one that can dissolve readily if the law cedes to the temptation to demarcate narrow fiduciary norms. The productive negation of legal agency is the actual outcome achieved by the supreme Court when it invokes fiduciary liabilities.

Obligating the state to assume a fiduciary relationship that substantively transforms the justice burdens upon it, thereby relativizing its legal agency and embracing an ongoing relationship to justice alterity and indeterminacy, makes Guerin a farsighted judgment.

The Court simultaneously affirms legal prerogative and sublates legal agency under the aegis of an other-regarding fiduciary relationship having prescriptive characteristics. A prescriptive fiduciary standard obligates the fiduciary to facilitate outcomes that accord with the interests of the beneficiary. Here the fiduciary cannot escape liability simply by standing by and making no error, but must potentially answer for the outcomes that the beneficiary confronts. 
Unlike a guardianship or conservatorship, the Crown's role is to ensure the enabling of aboriginal peoples' capacity without ever being able entirely to withdraw from the relationship. Aboriginal enabling vis-à-vis title to land, under this fiduciary doctrine, is restricted from embracing full legal agency. The prescriptive fiduciary duty to enable aboriginal peoples refracts the theme of resourcing justice alterity, explored earlier in this thesis. In essence, the Crown is charged with a relationship to the nonidentical both as regards itself as Crown and as regards aboriginal justice claims.

In contrast to the model explored by criddle and Fox-Decent, Guerin does not affirm the rule of law per se as axiomatic. Instead, the supreme court imposes on the Crown and aboriginal peoples a continuing relationship whose substantive other-regarding and otherenabling outcome is subject to court review. In Guerin, for example, it did not matter that the crown asserted that it had reached the best deal it could. It had done so without taking into account the breadth of its prescriptive fiduciary obligations, including that of consultation. 
It is notable that the supreme court's decision ascribes to the court the jurisdiction to examine the aggregate justice produced by the fiduciary obligations imposed on the Crown. For the court to take up a transformational role vis-à-vis the state by producing an analysis of justice alterity and indeterminacy is a significant step in the direction of embracing sustainable emancipatory justice claims.

The fiduciary analysis explored in this thesis allows a modeling of such sublated legal subjectivity that would no longer need to be legitimated by recourse to fragmented and somewhat contradictory foundations as evinced in Guerin.

\section{Elder Advocates}

The case of Elder Advocates ${ }^{595}$ presents us with the specific question of state fiduciary obligations outside of the confines of the Crown/aboriginal context. McLachlin CJC summarizes what was at stake in the case:

This case thus raises the question of when governments, as opposed to individuals, may be bound by a fiduciary duty. Fiduciary duty originated as

595 Alberta $v$ Elder Advocates of Alberta Society, 2011 SCC 24. For a commentary focusing on the remedial implications of this case as well as Galambos, supra note 537, see Ciara Toole, "Fiduciary Law and the Constructive Trust: Perfecting the Fiduciary Undertaking" (2011) 49 Alta L Rev 655. 
a private law doctrine. In the past, state actors have been held to be under a fiduciary duty in limited circumstances, namely, in discharging the Crown's special responsibilities towards Aboriginal peoples and where the crown is acting in a private capacity, as in its role as the public guardian and trustee. This claim does not fall within either of these situations. ${ }^{596}$

Elder Advocates thus directly addresses the contours and limits of state fiduciary obligations.

The case focuses on the laws concerning the funding of long-term health care for the aged in the province of Alberta. The respondent, here the representative in a class action suit, argued that the appellant (the Crown in Right of Alberta) was obligated by the Canada Health Act (CHA) to provide care without additional financial contributions ${ }^{597}$ by care facility residents. 598 An "accommodation charge" is a "charge in respect of nursing home care payable by a resident for accommodation and meals in a nursing home or an approved [hospital that provides nursing home care]". 599

The accepted statutory intent of the CHA was that "basic care" was the exclusive responsibility of the

\footnotetext{
597 Canada Health Act, RSC 1985, c C-6.

598 Outside of some very narrow exceptions, i.e., for user charges for "accommodation or meals provided to an in-patient who [...] requires chronic care and is more or less permanently resident in a hospital or other institution". See Canada Health Act, ibid s $19(2)$.

599 Alberta Health Care Insurance Act, RSA 2000, C A-20, ss 3-4.
} 
Province. In Alberta, long term care facilities are run either by the Province in the form of Regional Health Authorities or by private operators, both of which charge an accommodation fee not to exceed the limit set by regulations. ${ }^{600}$

The respondent argued that one third of the costs paid to the long-term care facilities by residents was in fact a subsidy for their basic medical care, which was entirely the responsibility of the Province to fund. McLachlin CJC writes:

The representative plaintiffs sought to certify a class action under the class Proceedings Act, S.A. 2003, C. C-16.5, maintaining that the crown and the RHAs have failed to ensure that the monies paid by the residents of LTCFs for "accommodation and meals" are used exclusively for that purpose. The pleadings allege that the Province is only allowed to charge for the actual cost of accommodation and meals, and not to use funds collected at the maximum level to subsidize basic care costs. They claim the residents of Alberta's chronic care facilities have been overcharged and seek return of the overpayment or damages. ${ }^{601}$

The Court of Appeal dismissed the Province's appeal and permitted a cross-appeal by the respondent. ${ }^{602}$ In its unanimous decision, the Court of Appeal reinstated

600 Alberta Health Care Insurance Act, RSA 2000, C A-20; Nursing Homes Act, RSA 2000, C N-7; and, Hospitals Act, RSA 2000, C H-12. 601 Alberta $V$ Elder Advocates of Alberta Society (SCC), supra note 595 at 15 . 602 Ibid. 
the claim that Alberta breached its fiduciary duty. The Province appealed to the Supreme court.

In Elder Advocates, the Supreme Court affirms generally the fiduciary model developed in Frame $V$ Smith, ${ }^{603}$ but makes clear that vulnerability in and of itself is not sufficient to ground a fiduciary obligation. ${ }^{604}$ The Supreme Court draws heavily on its decision in Guerin to support the contention that "[p]ublic law duties, the performance of which requires the exercise of discretion, do not typically give rise to a fiduciary relationship."605 AdditionalIy, the Court cites Wewaykum Indian Band ${ }^{606}$ to the effect that "[t]he crown can be no ordinary fiduciary; it wears many hats and represents many interests, some of which cannot help but be conflicting."607

\footnotetext{
603 See Frame V Smith [1987] 2 SCR 99 at 136 ("Relationships in which a fiduciary obligation has been imposed seem to possess three general characteristics: (1) The fiduciary has scope for the exercise of some discretion or power. (2) The fiduciary can unilaterally exercise that power or discretion so as to affect the beneficiary's legal or practical interests. (3) The beneficiary is peculiarly vulnerable to or at the mercy of the fiduciary holding the discretion or power.").

604 Cromwell J. concludes, "that while vulnerability in the broad sense resulting from factors external to the relationship is a relevant consideration, a more important one is the extent to which vulnerability arises from the relationship". See Galambos $V$ Perez, supra note 537 at 68. Quoted in Elder Advocates (SCC) supra note 595 at 28 .

605 Guerin $V$ The Queen, supra note 545 at 385.

606 Wewaykum Indian Band V Canada, 2002 SCC 79 at 96.

607 Ibid at 37.
} 
The Court then seeks to synthesize Guerin ${ }^{608}$, Hodgkinson $V$ Simms $^{609}$, and Galambos ${ }^{610}$ into a test intended to identify where fiduciary duties arise outside of established categories. The test consists of determining whether three criteria are met: (i) there is an undertaking by the fiduciary, express or implied; (ii) there is a duty owed to a defined person or class that is vulnerable to the discretionary power of the fiduciary; (iii) the fiduciary's power must be capable of impacting on an identifiable legal or vital practical interests of the beneficiary. ${ }^{611}$ These three criteria are to be analyzed in tandem with the Frame $V$ Smith vulnerability test.

The Supreme Court has undertaken according to each of these additional criteria to circumscribe the scope of fiduciary obligations. The court now openly affirms the possibility that the government may owe fiduciary duties to individuals or classes of individuals, but only in "limited and special circumstances."612

In what follows I will assess each of the criteria used by the court to delimit the range of situations

\footnotetext{
608 Guerin $V$ The Queen, supra note 545.

609 Hodgkinson $v$ Simms, [1994] 3 SCR 377.

610 Galambos V Perez, supra note 506 .

611 Alberta V Elder Advocates of Alberta Society (SCC), supra note 595 at $30-36$. 612 Ibid at 37 .
} 
in which crown fiduciary loyalty can arise. Because each of these criteria seeks to place the fiduciary relationship within the legal bounds of formal choice and defined responsibility, they amount to a hollowing out of the concept.

\section{(1) An expressed or implied undertaking}

As regards the first criterion, the court concludes that an "undertaking may be found in the relationship between the parties, in an imposition of responsibility by statute, or under an express agreement to act as trustee of the beneficiary's interests."613 This "will typically be lacking where what is at issue is the exercise of a government power or discretion."614 The Court relies on the presence of an undertaking to create the special relationship to a specific beneficiary. This would forbid generic fiduciary duties, as they would be indiscriminately open-ended.

In fact, the court reasons that the duty of utmost loyalty prohibits mediation between interests. ${ }^{615}$ It

\footnotetext{
613 Ibid at 32 .

614 Ibid at 42 .

615 Notwithstanding the courts desire to exclude consideration of Crown-Aboriginal peoples' relations, undertakings distinguished regarding Aboriginal peoples include the Royal Proclamation of 1763 to the Constitution Act, 1982 and others akin to those found in the private sphere. For example, the Royal Proclamation can be alternatively read as intending to only temporarily recognize Aboriginal rights, or as a nexus of their legal foundation. Section
} 
goes on to say that the duty to act in the best interests of the society as a whole and to "spread limited resources among competing groups with equally valid claims" 616 is at odds with a duty that would privilege "the best interests of the beneficiary" ${ }^{617}$. The Court concludes, that "[t]he Crown's broad responsibility to act in the public interest means that situations where it is shown to owe a duty of loyalty to a particular person or group will be rare."618

One way of approaching this first criterion is to ask how it squares with Guerin. To argue that aboriginal peoples are beneficiaries of a non-public, nonprivate obligation rooted in a sui generis right to which the Crown is accountable by virtue of an undertaking amounts to conceptual contortionism.

Such terminological opaqueness is a product of the limitations of existing legal language and categories, which are unable to express or embrace the justice alterity and indeterminacy at the core of fiduciary obligations. The Court's line of reasoning in El-

35 of the Constitution Act, 1982 does not define Aboriginal rights, and it has been left to the courts to determine their scope and depth.

616 Alberta $v$ Elder Advocates of Alberta Society (SCC), supra note 595 at 44 .

617 Ibid.

618 Harris V Canada, 2001 FCT 1408 at 78. 
der Advocates does little to address the complex challenges that the historical shift in the scope of fiduciary duties implies. In short, the first criterion is fraught with conceptual inadequacies that taken as a whole do little more than reprise previous attempts to canonize fixed fiduciary characteristics.

In fact, the "undertaking" criterion in the public law context is closely connected to the idea, promoted by Criddle and Fox-Decent, of a fiduciary duty undertaken by the state to provide stewardship of the laws. The reduction of fiduciary accountability to the reproduction of law and legal subjectivity precludes the possibility of orienting the public fiduciary toward social transformation. Indeed it leads to the inescapable conclusion that the state cannot even resource all existing legal subjectivity, let alone seek to enable emergent shifting subjectivity.

The legalistic turn taken in Elder Advocates has the Court engage in essence in asking itself whether a specific legal subjectivity - in this case that of recipients of health care - is designated by law as having to receive fiduciary resources. Yet even if this legal subjectivity cannot be fully resourced by law, this should say nothing about the existence of fiduci- 
ary obligations.

Fiduciary obligations can range from proscriptive to prescriptive, and each fiduciary relationship means making choices for the beneficiary among competing objectives. Each possible beneficiary trajectory could imply different, parallel, or opposing outcomes. The concept of fiduciary loyalty means in many cases that the fiduciary is continuously confronted with contradictory choices among various beneficiary needs and possible outcomes. When analyzed in this way, fiduciary loyalty means the selfless dedication to a process of possible beneficiary alterities.

This dedication is at the core of why the conceptualization of the undertaking is not universally supported.619 As Rotman points out, "neither Guerin nor Frame V Smith, cases which established the foundation

619 The support for an undertaking is considered a touchstone of the contractual understanding of fiduciary obligations. See generally, John H Langbein, "The Contractarian Basis of the Law of Trusts" (1995) 105:3 Yale LJ 625; AW Scott, "The Fiduciary Principle"(1949) 37 Cal L Rev 539 at 540; Lynn A Stout \& Margaret M Blair, "Trust, Trustworthiness, and the Behavioral Foundations of Corporate Law" SSRN elibrary, online: $<$ http://papers.ssrn.com/sol3/papers. cfm?abstract_id=241403>. Eileen A Scallen, "Promises Broken v Promises Betrayed: Metaphor, Analogy, and the New Fiduciary Principle" (1993) 1993 U Ill L Rev 897 at 926; John Glover, "The Identification of Fiduciaries" in Peter Birks, ed, Privacy and Loyalty (New York: Oxford University Press, USA, 1997) at 269-78. McLachlin J. asserted in Norberg V Wynrib, "[i]nherent in the notion of fiduciary duty [...] is the requirement that the fiduciary has assumed or undertaken to llook after' the interest of the beneficiary. [...] Generally people are deemed by the law to be motivated in their "relationships by mutual self-interest." See Norberg V Wynrib [1992] 2 SCR 226 at 98. 
of modern Canadian fiduciary jurisprudence indicate the requirement of undertaking for a fiduciary obligation to arise."620 Fiduciary duties are asserted by statute or other means in a number of contexts. ${ }^{621}$ Corporate directors are held to a fiduciary standard by the common law in the $\mathrm{US}^{622}$ and by statute in Canada. ${ }^{623}$

DeMott distinguishes A.W. Scott's oft-cited undertaking theory of a fiduciary duty. She writes:

In some relationships, determining the precise nature of the parties' "undertaking" is a difficult task. And in some situations, scott's formulation does not work at all. In what sense, for example, has a constructive trustee "undertaken" to act in the interests of the beneficiaries of the constructive trust? Typically the trust beneficiaries are the plaintiffs in litigation in which a court has imposed a constructive trust as a remedy. Only an overly attenuated conception of the trustee's "undertaking" could make sense in this context. ${ }^{624}$

Not surprisingly Frankel takes this discussion further:

If we view fiduciary law as a prohibition against taking what is not one's own and against acting negligently, then the duties that the law imposes

620 Rotman, supra note 263 at 95 .

621 See generally, Victor Brudney, "Contract and Fiduciary Duty in Corporate Law" (1997) 38:4 BC L Rev 595.

622 See generally, Stephen A Radin, The Business Judgment Rule: Fiduciary Duties of Corporate Officers, 6th ed (Clifton, NJ: Wolters Kluwer Law \& Business, 2009).

623 Canada Business Corporations Act, RSC 1985, C C-44 s 122(1)(a) ("Every director and officer of a corporation in exercising their powers and discharging their duties shall (a) act honestly and in good faith with a view to the best interests of the corporation.").

624 Deborah DeMott, "Beyond Metaphor: An Analysis of Fiduciary Obligation" (1988) 37 Duke LJ 879 at 910. 
arise when a person undertakes to perform a service effectively and takes property, or accepts power solely for that purpose. That is why it does not matter whether the relationship arose in connection with other legal arrangements or in isolation. The relationship may arise as an incidence of contract, trust, will, statute, charter, election, or without any legally binding arrangement. ${ }^{625}$

As Bruce Chapman asserts, "[p]roperly interpreted, the concepts of trust and loyalty present a deep challenge not only to that contractual model, but also to the very conventions of instrumental rationality upon which the model is based."626

It is true that the state's fiduciary duty cannot respond to an unlimited series of individualist legal subjectivities, each being able to claim exclusivity. State action is obligated to abstract from individual claims and to enable mutually supportive outcomes as among conflicting justice aggregates. A legal test that would focus the fiduciary's mandate on making transparent and responding to the impossibility of fulfilling this task would nevertheless have to resource the enabling of such indeterminate capacity.

The "undertaking" test cannot accomplish this, because no fiduciary can in fact formulate an express

625 Frankel, supra note 529 at 6.

626 Bruce Chapman, "Trust, Economic Rationality, and the Corporate Fiduciary Obligation" (1993) 43:3 U Chi L Rev 547 at 549. 
or implied undertaking to fulfill incommensurable other-regard. She can only expressly or impliedly accept the burden of this Sisyphean task. A polycentric fiduciary relationship is in no less fiduciary than one directed to a unitary beneficiary - arguably just the opposite is true.

To summarize, the Court's insistence on an express or implied undertaking by a public fiduciary is not consistent with its own reasoning, does not reflect any broad academic consensus on the nature of the fiduciary (both past or present), and is in fact inimical to core tensions in the fiduciary ethos.

Whereas it might be possible to conceive of an implied undertaking to enable selfless, otherregarding outcomes as arising out of all forms of mutual dependency, the supreme court has not set out this test so as to characterize a general social state. Rather, it has designed this criterion to operate so as to exclude most public relationships and is therefore aiming to confine the notion of implied undertaking

Yet, to return to Guerin, if a fiduciary undertaking to aboriginal peoples must be implied from the pattern of displacement, neglect and abuse that has 
been heaped upon them, surely a fiduciary undertaking to all legitimate public outcomes could be implied, as Criddle and Fox-Decent would claim, from the effort to produce just laws. Thus, either the supreme court's criterion is so narrow as to be inconsistent with Guerin, or so broad as to do none of the work claimed for it in delimiting public fiduciary loyalty.

\section{(2) A vulnerability to the fiduciary's discretionary power}

The Court's second criterion in Elder Advocates concerns the fiduciary's discretionary power. The existence and scope of fiduciary obligations is also to be inferred from the degree of discretion that a legal actor exercises over the rights of others. ${ }^{627}$

This second constraint is tautologically symbiotic with the first criterion. Fiduciary duties depend on "defining the person or class of persons vulnerable to the fiduciary's exercise of discretionary power."628 Here, the court cites Galambos to require that the beneficiary must prove that the fiduciary has forsaken

\footnotetext{
627 The Supreme Court itself previously stated in Lac Minerals that, "a fiduciary obligation can arise as a matter of fact out of the specific circumstances of a relationship." See Lac Minerals Ltd $v$ International Corona Resources Ltd, supra note 490 at 648 .

628 Alberta $V$ Elder Advocates of Alberta Society (SCC), supra note 595 at 49 .
} 
the "interests of all others in favour of himself or his class." 629

The exclusive duty in relation to aboriginal title "is established by the special crown responsibilities owed to this sector of the population and none other."630 At the same time, the court asserts that Crown must act in the interest of all citizens ${ }^{631}$ and is entitled to "make distinctions between different groups in the imposition of burdens or provision of benefits, subject to s. 15 of the Charter, which forbids discrimination."632 The court recognizes the possibility the Crown might in effect carry out a private duty and thus undertake fiduciary obligations (for example of an agent or trustee). Notably, however, the court concludes that, "[o]utside such cases, a specific class of persons to whom the government owes an exclusive duty of loyalty is difficult to posit."633

The interests of all citizens form the scope of possible legal obligations. MCLachlin CJC states unequivocally:

\footnotetext{
629 Ibid.

630 Ibid.

631 See Bennett $v$ British Columbia, 2009 BCSC 1358 at 71 . See also Drady V Canada, (2007) CanLII 27970 (ONSC) at 28; aff'd 2008 ONCA 659, 300 DLR (4th) 443; leave to appeal refused, [2009] $1 \mathrm{SCR}$ viii.

632 Alberta $v$ Elder Advocates of Alberta Society (SCC), supra note 595 at 49 .

633 Ibid.
} 
No fiduciary duty is owed to the public as a whole, and generally an individual determination is required to establish that the fiduciary duty is owed to a particular person or group. A fiduciary duty can exist toward a class - for example, adults in need of a guardian or trustee, or children in need of a guardian - but for a declaration that an individual is owed a duty, a person must bring himself within the class on the basis of his unique situation. Group duties have not often been found; thus far, only the Crown's duty toward Aboriginal peoples in respect of lands held in trust for them has been recognized on a collective basis. [emphasis added] ${ }^{634}$

Chief Justice McLachlin thus asserts that, "[f]iduciary duties do not exist at large [...] the duty must be owed to a defined person or class of persons who must be vulnerable to the fiduciary in the sense that the fiduciary has a discretionary power over them. " 635

Yet this argument involves a performative contradiction. If the state cannot be a fiduciary unless the beneficiary is distinguishable, but when a beneficiary is distinguished, this conflicts with the prohibition against allowing the state to serve only some interests at the expense of all others, then the supreme Court's test would exclude having a public fiduciary duty arise at all. McLachlin CJC draws a parallel con-

634 Ibid at 50 . 
clusion that leaves the emergence of public fiduciary loyalty elusive:

Fiduciary duties do not exist at large; they are confined to specific relationships between particular parties. Per se, historically recognized, fiduciary relationships exist as a matter of course within the traditional categories of trusteecestui que trust, executor-beneficiary, solicitorclient, agent-principal, director-corporation, and guardian-ward or parent-child. By contrast, ad hoc fiduciary relationships must be established on a case-by-case basis. ${ }^{636}$

Elder Advocates simply gives no account of how the evolution of fiduciary duties may indeed reflect on the public sphere.

In Elder Advocates, the Supreme Court attempts to avoid the adjudication of justice alterity and indeterminacy that are at the core of fiduciary duties. The attempt to restrict fiduciary obligations to identifiable groups ignores the role that the state has in constituting such categories.

Fiduciary duties have a long history as private law remedies that are available to address justice deficits of public law. The court's analysis turns the evolution of fiduciary duties on its head. As Rotman argues,

[c]ategories, by definition, cannot exist until there are a sufficient number of items of a simi-

636 Ibid. 
lar nature that can be logically grouped together. This reveals the inherent limitation in the categorical approach as an exclusive means of defining fiduciary relations: it could not have originated the process of definition. [...] Regarded in this light, it may be seen that even those so-called "traditional" categories were, at one time, novel applications of the fiduciary concept. [...] By subsequently denying the authority of fact-based determinations of fiduciary status, the status-based method disregards the appropriateness of the very methodology responsible for its existence. In truth, the status-based approach truly is only a consolidated, albeit limited, form of fact-based determinations. ${ }^{637}$

In $M(K) \quad V M(H)$, La Forest $J$ asserts that

the substance of the fiduciary obligation in any given case is not derived from some immutable list of duties attached to a category of fiduciary relationships. In other words, the duty is not determined by analogy with the 'established' heads of fiduciary duty. ${ }^{63}$

Worthington makes the parallel claim that,

[...] fiduciary obligations should be imposed not simply when certain descriptors are apt, but where the very function or purpose or reason for one party's role in the relationship demands that the party operate on the basis of self-denial."639

The affirmation that the fiduciary duty must be owed to a group whose definition exists for the court ignores the role and indeed fiduciary duty of the

\footnotetext{
637 Rotman, supra note 263 at 68.

$638 M(K) \quad V M(H)$ [1992] 3 SCR 3 at 326.

639 Sarah Worthington, "Fiduciaries: When Is Self-Denial Obligatory" (1999) 58 Cambridge LJ 500 at 506.
} 
state and the court in the production and reproduction of the group categories. There is no credible support for an interpretation of fiduciary obligations being restricted by the non-existence of a determinate category

This branch of the fiduciary test also suffers from the court's single-minded insistence upon containing the fiduciary conception within private law categories. For all the reasons explored in this thesis, private law categories are inherently incapable of rendering an account of the fiduciary constellation, since that constellation arises in the effort to overcome the limitations of those categories.

\section{(3) A power affecting a significant practical interest}

The third criterion for finding public fiduciary loyalty involves determining whether the government power affects a legal or significant practical interest :

[It] must be a specific private law interest to which the person has a pre-existing distinct and complete legal entitlement. Examples of sufficient interests include property rights, interests akin to property rights, and the type of fundamental human or personal interest that is implicated when the state assumes guardianship of a child or incompetent person. ${ }^{640}$

640 Alberta $v$ Elder Advocates of Alberta Society (SCC), supra note 595 at 51 . 
McLachlin CJC emphasizes that

[...] the degree of control exerted by the government over the interest in question must be equivalent or analogous to direct administration of that interest before a fiduciary relationship can be said to arise. The type of legal control over an interest that arises from the ordinary exercise of statutory powers does not suffice. Otherwise, fiduciary obligations would arise in most day to day government functions making general action for the public good difficult or almost impossible. ${ }^{641}$

The supreme court here eviscerates its own factual conceptualization of fiduciary obligations. The profound emphasis upon finding a private law nexus for fiduciary relationships asserted here interdicts any interrogation of the creation of fiduciary duties based on other considerations, including public control of property, ${ }^{642}$ reasonable expectations grounded in community standards, ${ }^{643}$ and vulnerability because of

\footnotetext{
641 Ibid at 53 .

642 See generally, Robert D Cooter \& Bradley J Freedman, "The Fiduciary Relationship: Its Economic Character and Legal Consequences" (1991) 66:4 NYU L Rev 1045.

643 In Hodgkinson $v$ Simms La Forest J writes that, "[t]he existence of a fiduciary duty in a given case will depend upon the reasonable expectations of the parties, and these in turn depend on factors such as trust confidence, complexity of subject matter, and community or industry standard." Hodgkinson v Simms, supra note 575. In Lac Minerals La Forest J's minority judgment asserts that fiduciary obligations depend on whether, [...] having regard to all the facts and circumstance [...] one party stands in relation to another such [...] that it could reasonably be expected that that other would act or refrain from acting in a way contrary to the interests, of that other." Lac Minerals Ltd $V$ International Corona Resources Ltd, supra note 490 at 40.
} 
asymmetry in power, ${ }^{644}$ to name just a few.

The finding of fiduciary duties in specific areas of state decision-making does not produce a generic fiduciary duty. The very reification of legal subjectivity that the supreme Court engages in precludes the admission of the necessity to resource the capacity for justice alterity and indeterminacy that are at the heart of a fiduciary metatheory. The Court's methodology is itself a source of the antinomical overburdening that it is trying to avoid.

The fundamental step that this thesis advocates is the admission of the macro-normative failure of "legal" regimes. Despite perhaps reaching in Elder Advocates the correct decision, the supreme court fundamentally miscasts the nature of fiduciary obligations, and fails to reflect their historical roots or their current normative potential.

The court might have appropriately resisted any affirmation in the lower courts that a fiduciary rela-

644 Vulnerability as a category is present in the Frame $v$ Smith fiduciary model, as well as in Lac Minerals. It is however downplayed in Hodgkinson. A succint definition of this category can be found in Burden v Miller: "[t] he common law imposes [a fiduciary] duty when the disparity between the parties in knowledge or power relevant to the performance of an undertaking is so vast that it is a reasonable inference that had the parties in advance negotiated expressly over the issue they would have agreed that the agent owed the principal the high duty that we have described [...]. See Burden V Miller, (1992) 957 F.2d 1375 at 1381. 
tionship mandates tying up specific resources in a specific way for an outcome determined by the beneficiary - here the attempt by the respondent to argue that the relevant public funds were earmarked for care facility residents and could not be used to meet competing health care needs.

The court could well have concluded, for example, that care facility residents have specific vulnerabilities that engage fiduciary responsibility of the state as a public provider of health care, but that this did not entail earmarking funds in the way sought. What the court failed to ask itself was whether the Crown had engaged in the task of fiduciary enabling •

That is, was the Crown's decision to seek an additional contribution from care facility residents and to redirect resources elsewhere into the health care system undertaken as part of an accountable effort to enable better outcomes for those residents. If Alberta could say nothing verifiable in answer to that question, it had not engaged in its fiduciary duty. If it could, it would be open to the court to conclude that it had no reason or independent legitimacy to call the Crown's own legitimacy into question. 
The Supreme Court's normative/epistemological nexus precludes an enabling that would embrace the emancipatory justice potential of a different disappointment ${ }^{0 / 1}$ outcome. This is particularly critical, because the focus of the supreme court judgment invalidates the normative critique that must accompany the articulation of emancipatory claims based on post-legal normative subjectivity.

By its omission, the court has contributed to the longstanding pattern of the misappropriation of fiduciary categories to prop up and obscure deficits of the "legal". A transformed understanding of the emancipatory potential underlying the interdependence of private/public fiduciary law would be a crucial step for the supreme court. An analysis of fiduciary obligations that would do justice to the considerations raised here would prompt a shift in social resourcing of greater fiduciary accountability. The reversal or modulation of macro-normative failure is impossible without it. 


\section{Conclusion}

This thesis has attempted both to re-define the fiduciary relationship and to enable it to bear specific antinomical burdens. In doing so, I neither wish to embrace the existing characterizations of the fiduciary relationship, nor do I supply a simple alternative reading. The fiduciary model presented here was intentionally built on tensions that would be compromised by the substitution of a new totality.

To this end I have introduced a modeling of justice that is built on the integration of emancipatory claims and their attendant antinomical burdens. The justice matrix allows for the iterative modeling of the relationship among contradictory claims. The justice matrix is essential to understanding the concept of the economy of affirmation, which links the normative and epistemic dimensions of our subjectivity with hegemonic societal practices.

The justice matrix invites us to model the deployment of justice resources, and to understand how this relates to the limits of our justice imaginary and justice horizon. This in turn explains why justice outcomes are never fixed, and are always the product 
of social resource allocations that are both intrinsically and extrinsically determined.

However, there is a lag, or latency, to the effects of any redeployment of resources toward new justice outcomes. The legacy of past investments of those resources persists in existing subjectivity. Legacy subjectivity extends itself into any reconfiguration of the justice matrix.

The antinomical burdens of legacy subjectivity are significant for the understanding of disappointment ${ }^{0 / 1}$. The persistence of legacy subjectivity, which is also always in the process of being re-cast, produces inevitable inadequacy to any actual justice outcomes. Disappointment ${ }^{0}$ arises because even those actors seeking emancipation will do so shaped by legacy subjectivity. Their disappointment will come from the experience of their own inadequacy to the transformed social setting. Disappointment ${ }^{1}$ arises because the achievement of any transformation comes at the price of producing what will always be revealed as an inadequate social reality. This thesis has focused on disappointment ${ }^{0 / 1}$, not so as to debunk the emancipatory justice claim, but rather so as to shed light on the ongoing inade- 
quacies that will require the investment of social resources if a practice of emancipation is to emerge.

Thus, emancipation is not an ex post state, but rather the adequate resourcing of fundamental emancipatory justice failures. The iterative demands of justice alterity and indeterminacy mean that emancipatory claims are in constant tension with the dominant normative and economic order, its instrumental epistemic substrate, and the constitutive subjectivity it depends on

The analysis of legal positivism introduced the concept of normative/epistemic thresholds, or unavoidabilities. These are significant for the reproduction of an economy of affirmation because of their autopoietic character. Normative/epistemic unavoidabilities result from the historic evolution and articulation of emancipatory claims. Using metatheory, every occurrence of positive law can be mapped onto the justice matrix and followed back to an emancipatory claim. Once this emancipatory claim ossifies into a normative/epistemic unavoidability, the emancipatory dimension and the justice imaginary are compromised.

In constant tension with this oscillation, theories of natural law posit the necessity for justice 
alterity as an openly emancipatory claim. Nevertheless, in an analogous move, justice claims are inflected through the limits of legacy subjectivity. In contemporary versions of such theories, to discern justice alterity (natural law) amounts to discerning the conditions that allow legacy subjectivity to flourish. Natural law does not break out of the threshold conditions linking it reproducing the existing order.

It is only with the concept of equity, throughout its historical iterations, that we saw potential for the full embrace of justice indeterminacy as a response to the law's inadequacy. Equity itself displays a wide range of intrinsic or extrinsic responsiveness to emancipatory claims, can overcome the normative/epistemic limitations of the legal, but lacks an overarching theoretical framework that allows for transparency or sustainability. Fiduciary obligations display the most far-reaching embrace of justice indeterminacy, but analogously have eluded clarification.

$$
\text { Adorno's negative dialectic provided a framework }
$$
for understanding why this has been the case, as well as suggesting normative/epistemic thresholds that can be applied to engage macro-normative issues. Adorno's 
theory is particularly suited to the task because of his focus on analyzing the normative/epistemic relationship between emancipatory claims, justice alterity, and justice indeterminacy.

The thesis closed with an analysis of the growth of other-regarding fiduciary duties and their potential relevance to macro-normative challenges. The critique of recent Supreme Court of Canada cases exemplified the shortcomings of existing fiduciary doctrine and jurisprudence in light of the theory elaborated here.

An evolved theory of the fiduciary is a potential fulcrum for emancipatory justice claims. Its historical differentiation out of equity has produced a unique normative regime that intentionally takes up much of what the legal inhibits. Localizing macronormative transformation in the fiduciary is also in line with the theory developed here that any transformation must work through the justice reserves of the existing economy of affirmation, without being defined by it.

The resourcing of justice alterity and indeterminacy are the key steps towards laying the framework for a Copernican normative turn. All this can only be- 
come possible if we are enabled to leave the confines of the legal and legacy subjectivity, and the limitations of our dominant economy of affirmation, without downloading the attendant risks on to the individual.

In a parallel methodological sense, it has been my intention to take each theme explored in this thesis and to impose upon it both a fiduciary burden towards a macro-normative critique, as well as to make it the beneficiary of a further meta-theoretical turn. I have undertaken to bring together relevant topoi, without succumbing to an aspirational tendency. I make no assumptions about the willingness or probability of outcomes. The thesis has as its goal the analysis of thresholds in methodologies and method. In this manner I undertake to inhibit normative/epistemic capture.

The thesis therefore shares its ethos with Adorno's writings. To be a fiduciary is to allow for the inadequacy of the task, as opposed to fetishizing situations whose resolution depends on the absence of such inadequacy. In short, the thesis has sought through its own method to remain as true as possible to the challenge faced by the fiduciary. Further research will focus on three elements (i) further evolving the analysis of Adorno's norma- 
tive/epistemological critique as regards emancipatory justice claims and moral theory; (ii) refining the justice matrix model towards a greater capacity for interacting with emancipatory initiatives and developments; and (iii) deepening the analysis of what forms of fiduciary obligations can be enabled to embrace practical macro-normative questions.

If fiduciary obligations were to evolve towards embracing the macro-normative challenges posed by emancipation, social accountability, and planetary sustainability, they could be of over-riding significance in overcoming the deficits imposed on us by our legacy subjectivity. A sophisticated and sufficiently differentiated fiduciary paradigm may finally give us the platform to internalize other-regarding to the point of overcoming the catastrophic normative/epistemic limitations of the law, relying as it does on projecting settled norms into the future. Given what we know about the underlying failure of our economy of affirmation, it is impossible to deny our complicity and collective fiduciary responsibility for the macro-justice deficits we are producing in real time. 


\section{Bibliography}

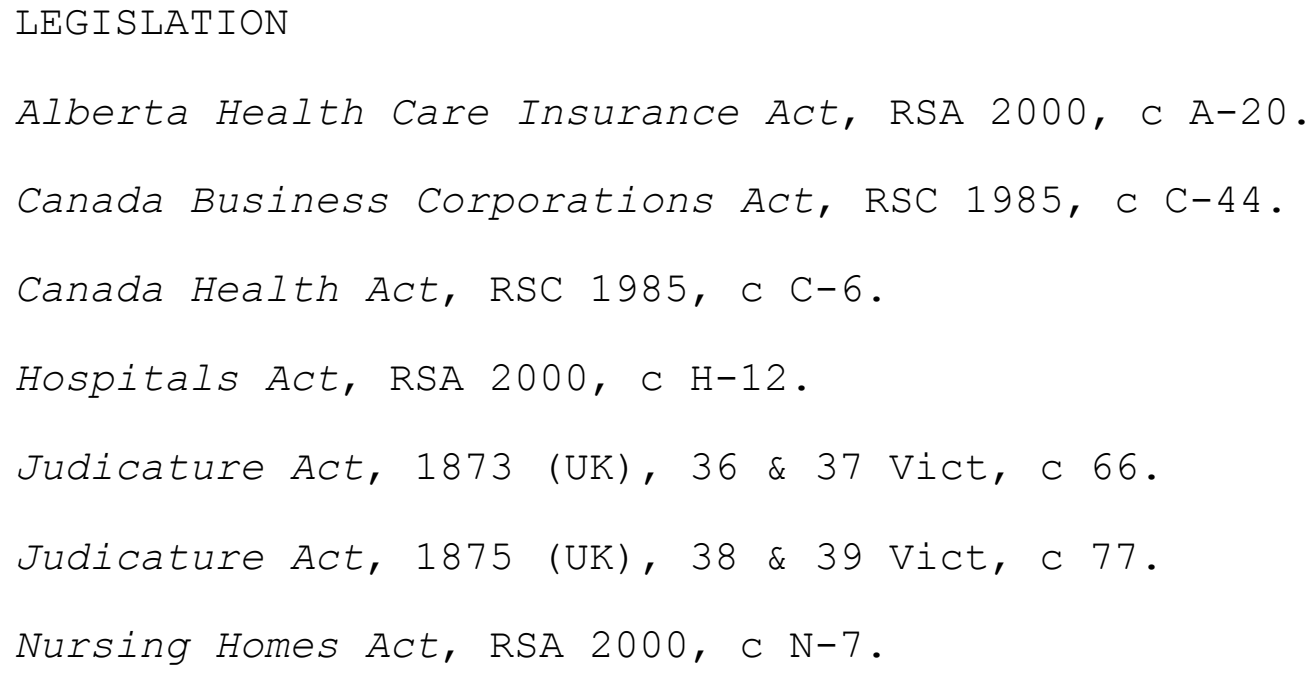


Guerin V The Queen, [1984] 2 SCR 335.

Guth $v$ Loft Inc, 5 A 2d 503.

Harris V Canada, 2001 FCT 1408.

Hodgkinson V Simms, [1994] 3 SCR 377.

Johnson $V M^{\prime}$ Intosh, 182321 US 543, 5 L Ed 681, 8 Wheat 543.

Keech V Sandford, 1726 Sel Cas Ch 61, 25 ER 223.

Lac Minerals Ltd $V$ International Corona Resources Ltd, [1989] 2 SCR 574.

Little Sisters Book and Art Emporium V Canada (Minister of Justice), 2000 SCC 69.

Market Street Associates Limited Partnership V Frey $H$ (1993), 21 F3d 1993 782, online <http://openjurist.org/21/f3d/782/market-streetassociates-limited-partnership-v-frey-h>.

Marsman v Nasca (1991), 5731991 NE 2d 1025.

Meinhard V Salmon, 164 NE 545.

$M(K) \quad V M(H) \quad[1992] \quad 3 \quad \mathrm{SCR} 3$ at 326.

Norberg V Wynrib [1992] 2 SCR 226.

Original Great American Chocolate Chip Cookie Company

Incorporated $V$ River Valley Cookies Limited M Sigel (1969), F2d 1969 273, online <http://openjurist.org/970/f2d/273/original-vriver>.

Osoyoos Indian Band V Oliver (Town), 2001 SCC 85. $R$ V Butler, [1992] 1 SCR 452.

R V Labaye, 2005 SCC 80 .

R V Sparrow, [1990] 1 SCR 1075.

R V Van der Peet, [1996] 2 SCR 507. 
Sharbern Holding Inc $v$ Vancouver Airport Centre Ltd, 2011 SCC 23.

Smith $V$ The Queen [1983] 1 SCR 554.

St Catherine's Milling and Lumber Co $V$ The Queen (1888) 14 App Cas 46 (PC).

Stewart V Canadian Broadcasting Corp, (1997) 150 DLR (4th) 24 (ONSC) .

Walley $v$ Walley, 16871 Vern 484.

Wewaykum Indian Band V Canada, 2002 SCC 79.

SECONDARY MATERIAL: MONOGRAPHS

Adams, George Burton. Council and Courts in AngloNorman England (New Haven: Yale University Press, 1926).

Adorno, Theodor W, Gretel Adorno \& Rolf Tiedemann. Aesthetic Theory, translated by Robert Hullot-Kentor (Minneapolis: University of Minnesota Press, 1997).

Adorno, Theodor W. Lectures on Negative Dialectics: Fragments of a Lecture Course 1965/1966, translated by Rodney Livingstone, Rolf Tiedemann, ed (Cambridge, MA: Polity, 2008).

Adorno, Theodor W. Negative Dialectics, translated by EB Ashton (New York: Continuum, 1981).

Adorno, Theodor W. Negative Dialectics, translated by Dennis Redmond, online: <http://members.efn.org/ dredmond/ndtrans.html>.

Agyeman, Julian \& Yelena Ogneva-Himmelberger. eds, Environmental Justice and Sustainability in the Former Soviet Union (Cambridge, MA: MIT Press, 2009).

Alexy, Robert. The Argument from Injustice: A Reply to Legal Positivism (Oxford: Clarendon Press, 2002). 
Amos, Sheldon. The Science of Law (Charleston, SC: Nabu Press, 2011).

Aquinas, st Thomas. Summa Theologica, translated by

Fathers of the English Dominican Province (New York: Cosimo, Inc, 2007).

Aristotle. Aristotelis Ars Rhetorica, translated by Moerbeke von William (Lipsiae: B. G. Teubneri, 1867 ).

Aristotle. Aristotle's Poetics, translated by Stephen Halliwell (Chicago: University of Chicago Press, 1998).

Aristotle, Ethica Nicomachea. Edward Cardwell, ed, (Oxford: Clarendon Press, 1828).

Aristotle. The Eudemian Ethics, translated by Anthony Kenny (Oxford: Oxford University Press, 2011).

Aristotle. The Nicomachean Ethics, translated by David Ross (Oxford: Oxford University Press, 2009).

Ashburner, Walter. Principles of Equity (Oxford: Butterworth \& Co., 1902).

Austin, John. Lectures on Jurisprudence, 3d ed (London: J. Murray, 1869).

Badiou, Alain. Circonstances: Tome 5, L'hypothèse Communiste (Paris: Nouvelles Editions Lignes, 2009).

Barlow, Frank. Edward the Confessor (New Haven: Yale University Press, 1997).

Bentham, Jeremy. Chrestomathia (London: Messrs. Payne and Foss, and R. Hunter, 1816).

Bentham, Jeremy. The Works of Jeremy Bentham, Sir John Bowring, ed (Edinburgh: W. Tait, 1843).

Bentham, Jeremy. A Comment on the Commentaries and A Fragment on Government, James Henderson Burns \& Herbert Lionel Adolphus Hart, eds (Oxford: Oxford University Press, 2009). 
Bentham, Jeremy \& Philip Schofield. Selected Writings: Jeremy Bentham (New Haven: Yale University Press, 2011).

Bergson, Henri. The Two Sources of Morality and Religion, translated by R Ashley Audra \& Cloudesley Brereton (Notre Dame, IN: University of Notre Dame Press, 1977).

Berryman et al. The Law of Trusts: A Contextual Approach, 2d ed, Mark R Gillen \& Faye Woodman, eds (Toronto: Emond Montgomery, 2008).

Blackstone, William. The Commentaries of Sir William Blackstone (Chicago, IL: American Bar Association, 2009).

Bluhdorn, Ingolfur \& Ian Welsh. eds, The Politics of Unsustainability: Eco-Politics in the Post-Ecologist Era (London: Routledge, 2008).

Böhme, Gernot. Ethics in Context: The Art of Dealing with Serious Questions, translated by Edmund Jephcott, lst ed (Cambridge, UK: Malden, MA: Polity, 2001).

Boke, George Henry. Cases in Equity (St Paul: West Publishing Co, 1915).

Brown, Peter G \& Geoffrey Garver. Right Relationship: Building a whole Earth Economy (San Francisco: Berrett-Koehler Publishers, 2009).

Buchwalter, Andrew. Dialectics, Politics, and the Contemporary Value of Hegel's Practical Philosophy (New York: Routledge, 2012).

Burle, E. Essai Historique sur le développement de la notion de droit naturel dans l'antiquité grecque (Ulan Press, 2012).

Cicero, Marcus Tullius. The Orations of Marcus Tullius Cicero, Charles Duke Yonge, ed (London: HG Bohn, 1856). 
Cicero, Marcus Tullius. De Re Publica: De legibus, translated by Clinton Walker Keyes (Cambridge, MA: Harvard University Press, 1961).

Coleman, Jules. The Practice of Principle: In Defense of a Pragmatist Approach to Legal Theory (Oxford: Oxford University Press, 2001).

Comte, Auguste. System of Positive Polity, translated by John Henry Bridges (Bristol: Thoemmes, 2001).

Congar, Yves. The Meaning of Tradition (San Francisco: Ignatius Press, 2004).

Cosgrove, Richard A. Scholars of the Law: English Jurisprudence from Blackstone to Hart (New York: New York University Press, 1996).

Cummiskey, David. Kantian Consequentialism (New York: Oxford University Press, 1996).

Davis, Evan, RE Baxter \& Graham Bannock. The Penguin Dictionary of Economics, 7th ed (London: Penguin, 2003).

Derrida, Jacques. Specters of Marx: The State of the Debt, the Work of Mourning, and the New International, translated by Peggy Kamuf (New York: Routledge, $1994)$.

Diamond, Jared M. Collapse: How Societies Choose to Fail or Succeed (New York: Viking, 2005).

Dicey, Albert Venn. Introduction to the Study of the Law of the Constitution 3d ed (London: MacMillan, 1889).

Diderot, Denis. Code De La Natur, Gilbert Chinard, ed (Paris: R. Clavreuil, 1950).

Dunn, Geoffrey. The Lies of Sarah Palin: the Untold Story behind Her Relentless Quest for Power (New York: St. Martin's Press, 2011) 
Entréves, Alexander Passerin d'. Natural Law: An Introduction to Legal Philosophy (New Brunswick, NJ: Transaction Publishers, 1951).

Falcón y Tella, María José. Equity and Law (Leiden: Martinus Nijhoff Publishers, 2008).

Finnis, John. Natural Law and Natural Rights, 2 d ed (Oxford: Oxford University Press, 2011).

Foucault, Michel. Power/Knowledge, translated by Colin Gordon (New York: Pantheon Books, 1980).

Fox-Decent, Evan. Sovereignty's Promise: The State as Fiduciary (Oxford: Oxford University Press, 2011).

Frankel, Tamar. Fiduciary Law: Analysis, Definitions, Relationships, Duties, Remedies over History and Cultures (Anchorage, AK: Fathom, 2008).

Frankel, Tamar. Fiduciary law (Oxford; New York: Oxford University Press, 2011).

Fukuyama, Francis. The End of History and the Last Man (New York: Free Press, 2006).

Fuller, Lon L. The Morality of Law (New Haven: Yale University Press, 1969).

Gaius. The Institutes of Gaius, translated by OF Robinson \& WM Gordon (London: Duckworth, 1988).

Glenn, H Patrick. Legal Traditions of the World: Sustainable Diversity in Law, 3d ed (Oxford: Oxford University Press, 2007).

Gregory, Chris A. Gifts and Commodities (London: Academic Press, 1982).

Goudie, Andrew. The Human Impact on the Natural Environment: Past, Present, and Future, 6th ed (Hoboken, NJ: Wiley-Blackwell, 2005).

Gregory, Chris A. Gifts and Commodities (London: Academic Press, 1982). 
Gripp-Hagelstange, Helga. Theodor W Adorno: Erkenntnisdimensionen negativer Dialektik (Paderborn: F. Schöningh, 1986) .

Habermas, Jürgen. The Theory of Communicative Action, translated by Thomas McCarthy (Boston: Beacon Press, $1984)$.

Haines, Charles Grove. The Revival of Natural Law Concepts, 4th ed (New York: Russell \& Russell, 1965).

Hake, Edward. Epieikeia, A Dialogue on Equity in Three Parts (New Haven: Yale University Press for the Yale Law Library, 1953).

Hanbury, Harold Greville. Essays in Equity (Oxford: Clarendon press, 1934).

Hargrave, Francis et al. The Abuses and Remedies of Chancery (Abingdon, Oxon: Professional Books, 1982).

Hart, HLA. The Concept of Law, 2d ed (New York: Oxford University Press, USA, 1997).

Hegel, Georg WF. Hegel's Philosophy of right, translated by Thomas Malcolm Knox (New York: Oxford University Press, 1975).

Hegel, Georg WF. Philosophie des Rechts: Die Vorlesung von 1819/20 in einer Nachschrift (Frankfurt am Main: Suhrkamp, 1983).

Herbermann, Charles George. The Catholic Encyclopedia: an international work of reference on the constitution, doctrine, discipline, and history of the Catholic Church (New York: Encyclopedia Press, 1913).

Hetherington, Marc J. Authoritarianism and Polarization in American Politics (New York: Cambridge University Press, 2009).

Hobbes, Thomas. Leviathan, Parts I and II (Calgary: Broadview Press, 2010). 
Hoffmann, Matthew J. Climate Governance at the Crossroads: Experimenting with a Global Response after Kyoto (Oxford: Oxford University Press, 2011).

Holdsworth, Sir William Searle \& John McDonald Burke. A History of English Law: The Judicial System (London: Methuen, 1956).

Holdsworth, William Searle. A History of English Law, 7th ed, Arthur L. Goodhart \& Harold Greville Hanbury, eds. (London: Methuen, 1956).

Holz, Hans Heinz. Dialektik: Problemgeschichte von der Antike bis zur Gegenwart (Darmstadt: WBG (Wissenschaftliche Buchgesellschaft), 2011).

Homer. The First Six Books of Homer's Iliad, translated by Charles Anthon (New York: Harper, 1876).

Horkheimer, Max. Critique of Instrumental Reason, translated by Matthew O'Connell (London, Verso 2012).

Horkheimer, Max. Eclipse of Reason (New York: Continuum, 1985).

Horkheimer, Max \& Theodor W Adorno. Dialectic of Enlightenment, translated by John Cumming (New York: Continuum, 1999).

Hume, David. An Inquiry Concerning Human Understanding, Charles William Hendel, ed (Upper Saddle River, NJ: Prentice Hall, 1997).

Humphreys, Stephen. Theatre of the Rule of Law: Transnational Legal Intervention in Theory and Practice (Cambridge, UK: Cambridge University Press, 2010).

Jameson, Fredric Jameson. Postmodernism, or, The Cultural Logic of Late Capitalism, Reprint ed (Durham: Duke University Press Books, 1990) Postmodernism, or, The Cultural Logic of Late Capitalism, Reprint ed (Durham: Duke University Press Books, 1990). 
Johnston, David. The Roman Law of Trusts (Oxford: Clarendon Press, 1988).

Justinian. The Digest of Justinian, Alan Watson, ed (Philadelphia: University of Pennsylvania Press, 2011).

Kant, Immanuel. Immanuel Kant: Kritik Der Reinen Vernunft, Georg Mohr \& Marcus Willaschek, eds. (Berlin: Akademie Verlag, 1998).

Kant, Immanuel. Critique of Pure Reason, translated by Werner S Pluhar, Eric Watkins, ed (Indianapolis, IN: Hackett, 1999).

Kant, Immanuel. Groundwork for the Metaphysics of Morals, translated by TK Abbott (Calgary: Broadview Press, 2005).

Keeton, George Williams \& LA Sheridan. Equity, 3d ed (Chichester, West Sussex: Barry Rose, 1987).

Kelsen, Hans. Pure Theory of Law (Berkeley: University of California Press, 1978).

Kelsen, Hans. General Theory of Law and State (Clark, NJ: The Lawbook Exchange, 2007).

Kennedy, Duncan. Legal Reasoning: Collected Essays (Aurora, Colo: Davies Group Publishers, 2008).

Kerly, Duncan Mackenzie. An Historical Sketch of the Equitable Jurisdiction of the Court of Chancery (Cambridge, UK: University Press, 1890).

Klein, Naomi. The Shock Doctrine: The Rise of Disaster Capitalism (New York: Metropolitan Books/Henry Holt, 2007 ).

Klinck, Dennis R Conscience, Equity and the Court of Chancery in Early Modern England (Farnham, Surrey: Ashgate, 2010).

Kojève, Alexandre. Introduction à la lecture de Hegel: leçons sur la Phénoménologie de l'esprit professées 
de 1933 à 1939 à l'Ecole des hautes études (Paris: Gallimard, 1968).

Lambarde, William. Archeion, Charles Howard McIlwain \&

Paul L Ward, eds (Cambridge, MA: Harvard University Press, 1957).

Lepore, Jill. The Whites of their Eyes (Princeton, NJ: Princeton University Press, 2010).

Lieberman, Jethro Koller. The Litigious Society (New York: Basic Books, 1983).

Luhmann, Niklas. A Sociological Theory of Law, translated by Martin Albrow \& Elizabeth King (London: Routledge \& Kegan Paul, 1985).

Mack, Mary Peter. Jeremy Bentham: An Odyssey of Ideas (New York: Columbia University Press, 1963).

Maine, Sir Henry James Sumner. Ancient Law (London: Dent, 1972).

Mandel, Ernest. Late Capitalism (London: Verso, 1998). Manderson, Desmond. Proximity, Levinas and the Soul of Law (Montreal: McGill-Queen's Press, 2006).

Mayer, Jane. Covert Operations (2010), online: <http://www. newyorker.com/reporting/2010/08/30/10083 0 fa_fact_mayer>.

McIlwain, Charles Howard. The Growth of Political Thought in the West, from the Greeks to the end of the Middle Ages. (New York: Cooper Square Publishers, 1968).

Menke, Christoph \& Axel Honneth. Theodor W Adorno: Negative Dialektik (Berlin: Akademie Verlag, 2006). Moore, GE. Principia Ethica (Mineola, NY: Dover Publications, 2004$)$.

Mortimer, Robert Cecil. Western Canon Law (Berkeley: University of California Press, 1953). 
Newman, Louis E Past imperatives: Studies in the History and Theory of Jewish Ethics (Albany, NY: State University of New York Press, 1998).

Newton, Sir Isaac \& Florian Cajori. Sir Isaac Newton's Mathematical Principles of Natural Philosophy and His System of the World: The System of the World (Berkeley: University of California Press, 1962).

Nicholas, Barry \& Ernest Metzger. An Introduction to Roman Law, Revised ed (Oxford: Oxford University Press, 1975).

Nietzsche, Friedrich Wilhelm. Human, All Too Human: A Book for Free Spirits, translated by Marion Faber (Lincoln, NE: University of Nebraska Press, 1996).

Nottingham, Heneage Finch \& D E C Yale. Lord Nottingham's Chancery Cases (London: B Quaritch, 1957).

o'Connor, Brian. Adorno's Negative Dialectic: Philosophy and the Possibility of Critical Rationality (Cambridge, MA: MIT Press, 2004).

Painter, Sidney. A History of the Middle Ages: 2841500. (New York: Knopf, 1956).

Parsons, Talcott. The System of Modern Societies (Englewood Cliffs, NJ: Prentice-Hall, 1971).

Pettit, Philip Henry. Equity and the Law of Trusts, 11th ed (Oxford: Oxford University Press, 2009).

Plato. Laws, translated by Benjamin Jowett (Champaign, IL: Project Gutenberg, 199AD) at 94, online: <http://www.gutenberg.org/ebooks/1750>.

Plato. The Republic, translated by Allan Bloom (New York: Basic Books, 1991)

Pollock, Frederick. Essays in the Law (London: Macmillan, 1922).

Pollock, Sir Frederick. Jurisprudence and Legal Essays (New York: St. Martin's Press, 1978). 
Posner, Richard. Economics of Justice (Cambridge, MA: Harvard U Press, 1983).

Postema, Gerald J. Bentham: Moral, Political, and Legal Philosophy (Aldershot, UK: Ashgate, 2002).

Rademacher, Claudia. Versöhnung oder Verständigung?: Kritik der Habermasschen Adorno-Revision (Lüneburg: Klampen, 1993).

Radin, Stephen A. The Business Judgment Rule: Fiduciary Duties of Corporate Officers, 6th ed (Clifton, NJ: Wolters Kluwer Law \& Business, 2009).

Rawls, John. A Theory of Justice (Cambridge, MA: Belknap Press of Harvard University Press, 1971).

Rawls, John \& HLA Hart. Essays on Bentham: Studies in Jurisprudence and Political Theory (Oxford: Clarendon Press, 1982).

Raz, Joseph. The Morality of Freedom (Oxford: Oxford University Press, 1988).

Raz, Joseph. The Authority of Law: Essays on Law and Morality (Oxford: Oxford University Press, 2009).

Reddaway, Peter \& Sidney Bloch. Soviet Psychiatric Abuse: The Shadow Over World Psychiatry (Boulder, Colo: Westview Press, 1985).

Ringer, Fritz K. Die Gelehrten: Der Niedergang der deutschen Mandarine 1890-1933 (Stuttgart: KlettCotta, 1983).

Rotman, Leonard Ian. Fiduciary Law (Toronto: Thomson Carswell, 2005).

Russell, Joseph J. Analysis and Dialectic: Studies in the Logic of Foundation Problems (The Hague: M Nijhoff, 1984).

Saint German, Christopher. Doctor and Student (London: Selden Society, 1974). 
Salehi-Isfahani, Djavad \& Jacques Crémer. Models of the Oil Market (Chur: Harwood Academic Publishers, 1991).

Salmond, Sir John William. Salmond on Jurisprudence (Andover: Sweet \& Maxwell, 1957).

Sarna, Nahum M, Marc Zvi Brettler \& Michael A Fishbane. Minhah le-Nahum: Biblical and other Studies presented to Nahum $M$. Sarna in Honour of his 70th birthday (Sheffield, UK: JSOT Press, 1993).

Schiller, A Arthur. Roman Law: Mechanisms of Development (The Hague: Mouton, 1978).

Schneider, Norbert. Erkenntnistheorie im 20. Jahrhundert: klassische Positionen (Stuttgart: Reclam, $1998)$.

Sinclair, Adriana. International Relations Theory and International Law: A Critical Approach (Cambridge, UK: Cambridge University Press, 2010).

Sloterdijk, Peter. Critique of Cynical Reason, translated by Michael Eldred (Minneapolis: University of Minnesota Press, 1987).

Snell, Edmund Henry Turner. Snell's Equity, John McGhee, ed. (Andover: Sweet \& Maxwell, 2005).

Sohm, Rudolf. The Institutes: A Text-book of the History and System of Roman Private Law, 2d ed, translated by James Crawford Ledlie (Oxford: Clarendon Press, 1901).

Spence, George \& Henry Maddock. The Equitable Jurisdiction of the court of Chancery (Charleston, SC: Nabu Press, 2011).

Story, Joseph. Commentaries on Equity Jurisprudence: As Administered in England and America, 5th ed (London: $V$ \& $R$ Stevens and GS Norton, 1849).

Sullivan, Roger J Immanuel Kant's Moral Theory (Cambridge, UK: Cambridge University Press, 1989). 
Taylor, Charles. Sources of the Self: The Making of the Modern Identity (Cambridge, MA: Harvard University Press, 1992).

Thomas, Hugh M. The Norman Conquest: England after William the Conqueror (Lanham: Rowman \& Littlefield Publishers, 2008).

Thyen, Anke. Negative Dialektik und Erfahrung: Zur Rationalitat des Nichtidentischen bei Adorno (Frankfurt am Main: Suhrkamp, 1989).

Tonelson, Alan. The Race to the Bottom (Boulder, Colo: Westview Press, 2000).

Vinogradoff, Sir Paul. The Collected Papers of Paul Vinogradoff: Jurisprudence, Herbert Albert Laurens Fisher, ed. (Oxford: Clarendon Press, 1928).

Walsh, William Francis. Cases on Equity (Chicago: Callaghan, 1937).

Waters, DWM, ed. Waters' Law of Trusts in Canada, 3d ed (Toronto: Thomson Carswell, 2005).

Weber, Max. Max Weber on Law in Economy and Society, translated by Max Rheinstein \& Edward Shils (New York: Simon and Schuster, 1954).

Wexler, Steve M. On the Other Hand: Retranslating Aristotle on law (2008) at 97, online: < http://faculty.law.ubc.ca/wexler/pdf/on_the_other_ot her_hand.pdf $>$.

Wiggerhaus, Rolf. The Frankfurt School: Its History, Theories, and Political Significance, translated by Michael Robertson (Cambridge, MA: MIT Press, 1995).

Zima, P V. What is Theory?: Cultural Theory as Discourse and Dialogue (London: New York: Continuum, $2007)$.

Žižek, Slavoj. Living in the End Times (London: Verso, 2010). 
The Oxford English Dictionary, 2d ed (New York: Oxford University Press, USA).

SECONDARY MATERIALS: ARTICLES

Bandera, VN. "New Economic Policy (NEP) as an Economic Policy" (1963) $71 \mathrm{~J}$ Pol EC 3.

Barnosky, Anthony D et al. "Approaching a State Shift in Earth's Biosphere" (2012) 486:7401 Nature 52.

Beck-Dudley, Caryn L \& Edward J Conry. "Legal Reasoning and Practical Reasonableness" (1995) 33:1 American Business Law Journal 91.

Brudney, Victor. "Contract and Fiduciary Duty in Corporate Law" (1997) 38:4 BC L Rev 595.

Brutau, Puig. "Juridical Evolution and Equity" in Ralph Abraham Newman \& Sheldon Glueck, eds, Essays in Jurisprudence in Honor of Roscoe Pound (Indianapolis: Bobbs-Merrill, 1962).

Bryant, Michael. "Crown-Aboriginal Relationships in Canada: The Phantom of Fiduciary Law" (1993):27 UBC L Rev 19.

Butler, HN \& Ribstein, LE. "Opting out of Fiduciary Duties: A Response to the Anti-Contractarians" (1990) 65 Wash L Rev 1.

Chapman, Bruce. "Trust, Economic Rationality, and the Corporate Fiduciary Obligation" (1993) 43:3 U Chi L Rev 547.

Clark, Thomas W. "Fear Mechanism: A Compatibilist Critique of the "Volitional Brain'" in Keith Sutherland, Anthony Freeman \& Benjamin Libet, eds, The Volitional Brain: Towards a Neuroscience of Free Will (Exeter, UK: Imprint Academic, 2004) 279.

Cohn, HH. "Ancient Jewish Equity" in Ralph Abraham Newman \& René Cassin, eds, Equity in the World's Le- 
gal Systems: A Comparative Study, Dedicated to René Cassin (Brussels: Établissements Émile Bruylant, 1973).

Cooter, Robert D \& Bradley J Freedman. "The Fiduciary Relationship: Its Economic Character and Legal Consequences" (1991) 66:4 NYU L Rev 1045.

Cox, O. "The Meaning of Law in the Concept of Law" (1999) 24 Austl J Leg Phil 145.

Coyle, Michael. "Loyalty and Distinctiveness: A New Approach to the Crown's Fiduciary Duty toward Aboriginal Peoples" (2002) 40 Alta L Rev 841.

Criddle, Evan J. "Fiduciary Foundations of Administrative Law" (2006) 54 UCLA L Rev 117.

Criddle, Evan J. "Fiduciary Administration: Rethinking Popular Representation in Agency Rulemaking" (2008) 88 Tex L Rev 441.

Criddle, Evan J \& Fox-Decent, Evan. "A Fiduciary Theory of Jus Cogens" (2009) 34 Yale J Int'l L 331.

Crowe, Jonathan "Self and Other in Ethics and Law: A Comment on Manderson" (2008) 33 Austl J Leg Phil 145 .

Danielson, Peter. "Book Review: Natural Law and Natural Rights" (1980) 30:4 U of T LJ 441.

DeMott, Deborah. "Beyond Metaphor: An Analysis of Fiduciary Obligation" (1988) 37 Duke LJ 879.

DeMott, Deborah A. "Fiduciary Obligation under Intellectual Siege: Contemporary Challenges to the Duty to be Loyal" (1992) 30 Osgoode Hall LJ 471.

Eisen, Robert. "Lifnim Mi-Shurat Ha-Din in Maimonides Mishneh Torah" (1999) 89:3/4 The Jewish Quarterly Review 291.

Endicott, Timothy. "The Impossibility of the Rule of Law" (1999) 19 Oxford J L Studies 1. 
Fay, Brian. "Theory and Metatheory in Social Scienceor, Why the Philosophy of Social Science Is So Hard" (1985) 16:2-3 Metaphilosophy 150.

Finn, Paul. "The Fiduciary Principle" in T G Youdan, ed, Equity, Fiduciaries and Trusts (Toronto: Carswell, 1989).

Finn, Paul. "Public Trusts, Public Fiduciaries" (2010) 38 Fed L Rev 335.

Finnis, John. "Natural Law Tradition" (1986) $36 \mathrm{~J}$ Legal Educ 492.

Finnis, John. "Law, Morality and Sexual Orientation" in Human Rights and Common Good: Collected Essays (Oxford University Press, 2011).

Flores, Imer B \& Jorge Luis Fabra. "50th Anniversary of Hart's the Concept of Law" (2011) SSRN elibrary, online:

<http://papers.ssrn.com/sol3/papers.cfm?abstract_id= 2015063>.

Fox-Decent, Evan. "The Fiduciary Nature of State Legal Authority" (2005) 31 Queen's LJ 259.

Frankel, Tamar. "Fiduciary Law" (1983) 71 Cal L Rev 795.

Frankel, Tamar. "Fiduciary Duties as Default Rules" (1995) 74 Or L Rev 1209.

Fuller, Lon L. "Positivism and Fidelity to Law--A Reply to Professor Hart" (1957) 71 Harv L Rev 630.

George Burton Adams. "The Continuity of English Equity" (1917) 26:7 Yale LJ 550.

Glover, John. "The Identification of Fiduciaries" in Peter Birks, ed, Privacy and Loyalty (New York: Oxford University Press, USA, 1997). 
Goethe, Johann Wolfgang von. "Torquato Tasso" in Goethes Werke 5, Dramatische Dichtungen: (Hamburg: Wegner, 1952).

Goldworth, Amnon. "Bentham's Concept of Pleasure: Its Relation to Fictitious Terms" (1972) 82:4 Ethics 334 .

Gordley, James. "The Moral Foundations of Private Law", (2002) 47 Am J of Jurisprudence 1 .

Hare, RM. "Could Kant Have Been A Utilitarian?" (1993) 5:01 Utilitas 1 .

Hart, HLA. "Positivism and the Separation of Law and Morals" (1957) 71 Harv L Rev 593.

Hayton, David. "Fiduciaries in Context: An Overview" in Peter Birks, ed, Privacy and Loyalty (New York: Oxford University Press, USA, 1997) 284.

Hoerster, Norbert. "Die rechtsphilosophische Lehre vom Rechtsbegriff" (1987) JuS 181.

Hohfeld, Wesley. "Fundamental Legal Conceptions as Applied in Judicial Reasoning" (1913) 23 Yale LJ 16

Hohfeld, Wesley. "Fundamental Legal Conceptions as Applied in Judicial Reasoning" (1917) 27 Yale LJ 710.

Holmes, Oliver Wendell. "The Path of Law" in Harold Joseph Laski, ed, Collected Legal Papers (New York: Harcourt, Brace and Howe, 1920).

Hoyano, LCH. "The Flight to the Fiduciary Haven" in Peter Birks, ed, Privacy and Loyalty (New York: Oxford University Press, USA, 1997).

Janda, Richard. "Law's Limits" (1989) 63 S Cal L Rev 727 .

Janda, Richard. "Equity, Legal Architecture, and Christopher St German" in Brierley et al \& Centre de recherche en droit privé et comparé du Québec, eds, 
Mélanges Paul André Crépeau (Cowansville: Éditions Blais, 1997).

Keane, PA. "The $2009 \mathrm{Wa}$ Lee Lecture in Equity: The Conscience of Equity" (2010) 10:1 Law and Justice Journal 106 .

Kennedy, Duncan. "Left Phenomenological Alternative to the Hart/Kelsen Theory of Legal Interpretation" in Legal Reasoning: Collected Essays (Aurora, Colo: Davies Group Publishers, 2008).

Kirschenbaum. "Jewish Law and Aristotelian Equity" in Alfredo Mordechai Rabello \& Israel B Greene and Sara Mann Greene Fund for Equity Studies, eds, Aequitas and Equity: Equity in Civil Law and Mixed Jurisdictions (Jerusalem: Harry and Michael Sacher Institute for Legislative Research and Comparative Law, the Hebrew University of Jerusalem, 1997).

Koller, Peter. "The Concept of Law and Its Conceptions"(2006) 19:2 Ratio Juris 180.

Langbein, John $\mathrm{H}$. "The Contractarian Basis of the Law of Trusts" (1995) 105:3 Yale LJ 625.

Lehun, Richard. "Affirmation und Schein" in Gisela Engel \& Gisela Notz, eds, Sinneslust und Sinneswandel: Beiträge zu einer Geschichte der Sinnlichkeit (Berlin: Trafo, 2001).

Leiter, B. "Beyond the Hart/Dworkin Debate: The Methodology Problem in Jurisprudence" (2003) 48 Am J Juris 17 .

Libecap, Gary D. "Contracting for Property Rights" in Terry Lee Anderson \& Fred S McChesney, eds, Property Rights: Cooperation, Conflict, and Law (Princeton, NJ: Princeton University Press, 2003) 145.

Macdonald, Roderick A \& Martha-Marie Kleinhans. "What is a Critical Legal Pluralism" (1997) 12 Can J L \& Soc 25. 
Markham, Jerry W. "Jerry W. Markham, Fiduciary Duties Under the Commodity Exchange Act" (1992) 68 Notre Dame L Rev 199.

McCamus, JD. "The Evolving Role of Fiduciary Obligation" in Meredith Memorial Lectures 1998-1999 (Cowansville, Québec: Éditions Yvon Blais, 2000).

McReynolds, Paul. "The Motivational Psychology of Jeremy Bentham: II. Efforts toward Quantification and Classification" (1968) 4:4 Journal of the History of the Behavioral Sciences 349.

Miller, Paul B. "A Theory of Fiduciary Liability" (2010) 56 McGill L J 235.

Newman, Ralph A. "The Place and Function of Pure Equity in the structure of Law" (1964) 16 Hastings LJ 401 .

Parsons, Talcott. "On the Concept of ValueCommitments" (1968) 38:2 Sociological Inquiry 135.

Perillo, Joseph M. "Origins of the Objective Theory of Contract Formation and Interpretation, The" (2000) 69 Fordham L Rev 427.

Perry, Stephen. "Hart's Methodological Positivism" (1998) 4:04 Legal Theory 427.

Ponet, David L \& Ethan J Leib. "Fiduciary Law's Lessons For Deliberative Democracy" (2009) 34 Yale J Int'l L 331 .

Posner, Richard A. "The Sociology of the Sociology of Law: A View from Economics" (1995) 2:4 Eur JL \& Econ 265 .

Radbruch, Gustav. "Five Minutes of Legal Philosophy (1945)" (2006) 26:1 Oxford J Legal Studies 13.

Radbruch, Gustav. "Statutory Lawlessness and SupraStatutory Law (1946)" (2006) 26:1 Oxford J Legal Studies 1 . 
Rayman, Joshua. "Adorno's American Reception" (2009) 2009:149 Telos 6 .

Raz, Joseph. "Can There Be a Theory of Law?" SSRN eLibrary, online:

<http://papers.ssrn.com/sol3/papers.cfm?abstract_id= $1010287>$.

Reiter, Eric. "Fact, Narrative, and the Judicial Uses of History: Delgamuukw and Beyond" (2010) 2010 Indigenous LJ 55.

Richardson, JS. "The Ownership of Roman Land: Tiberius Gracchus and the Italians" (1980) 70 The Journal of Roman Studies 1 .

Rotman, Leonard Ian. "Crown-Native Relations as Fiduciary: Reflections Almost Twenty Years After Guerin" (2003) 22 Windsor YB Access Just 363.

Scalia, A. "The Rule of Law as a Law of Rules" (1989) 56:4 U Chi L Rev 1175 .

Scallen, Eileen A. "Promises Broken V. Promises Betrayed: Metaphor, Analogy, and the New Fiduciary Principle" (1993) 1993 U Ill L Rev 897.

Schlag, Pierre. "Spam Jurisprudence, Air Law, and the Rank Anxiety of Nothing Happening (a Report on the State of the Art)" (2007) SSRN eLibrary, online: <http://papers.ssrn.com/sol3/papers.cfm?abstract_id= $976078>$.

Schofield, P. "Jeremy Bentham, the Principle of Utility, and Legal Positivism" (2003) 56:1 Current Legal Problems 1 .

Sealy, LS. "Fiduciary Relationships" (1962) 20:01 The Cambridge Law Journal 69.

Sen, Amartya. "The Possibility of Social Change" in Torsten Persson, ed, Nobel Lectures in Economic Sciences, 1996-2000 (London: World Scientific Pub Co Inc, 2003). 
Shellens, Max Salomon. "Aristotle on Natural Law" (1959) 4 Natural L Forum 72.

Smith, D Gordon. "The Critical Resource Theory of Fiduciary Duty" SSRN eLibrary, online:

<http://papers.ssrn.com/sol3/papers.cfm?abstract_id= $339100>$.

Smith, Sidney. "The Stage of Equity" (1938) 11:308 Can B Rev 311.

Stein, P. "Equitable Principles in Roman Law" in René Cassin \& Ralph Abraham Newman, eds, Equity in the World's Legal Systems: A Comparative Study, dedicated to René Cassin (Brussels: Établissements Émile Bruylant, 1973).

Stout, Lynn A \& Margaret M Blair. "Trust, Trustworthiness, and the Behavioral Foundations of Corporate Law" SSRN eLibrary, online:

<http://papers.ssrn.com/sol3/papers.cfm?abstract_id= $241403>$.

Summers, Robert S. "Professor HLA Hart's 'Concept of Law" (1963) 4 Duke LJ 629.

Swedberg, Richard. "Max Weber's Contribution to the Economic Sociology of Law" (2006) 2:1 Annual Review of Law and Social Science, online:

<http://wWw. annualreviews.org.ezpprod1.hul .harvard.edu/doi/abs/10.1146/annurev.lawsoc sci.2.081805.105800>.

Toole, Ciara. "Fiduciary Law and the Constructive Trust: Perfecting the Fiduciary Undertaking" (2011) 49 Alta L Rev 655.

Vinogradoff, Paul. "Legal Standards and Ideals" (1924) 23:1 Mich L Rev 1.

Waldron, J. "Kant's Legal Positivism" (1996) 109:7

Harv L Rev 1535. 
Waters, Donovan WM. "The Reception of Equity in the Supreme Court of Canada (1875-2000)" (2001) 80 Can Bar Rev 620.

Weinrib, EJ. "The Fiduciary Obligation" (1975) 25:1 U Toronto LJ 1.

Wexler, Steve \& A Irvine. "Aristotle on the Rule of Law" (2006) 23:1 Polis: The Journal of the Society for Greek Political Thought 116.

Worthington, Sarah. "Fiduciaries: When Is Self-Denial Obligatory" (1999) 58 Cambridge LJ 500.

Zaibert, Leo \& Barry Smith. "Legal Ontology and the Problem of Normativity" (1999) The AnalyticContinental Divide, Conference, University of Tel Aviv.

Zepos, PJ. "Equity in Greek Law" in René Cassin \& Ralph Abraham Newman, eds, Equity in the World's Legal Systems: A comparative Study, dedicated to René Cassin (Brussels: Établissements Émile Bruylant, 1973). 